Access, Power and Justice in Commodity Frontiers.

The political ecology of access to land and palm oil expansion in Colombia

Victoria Marin-Burgos
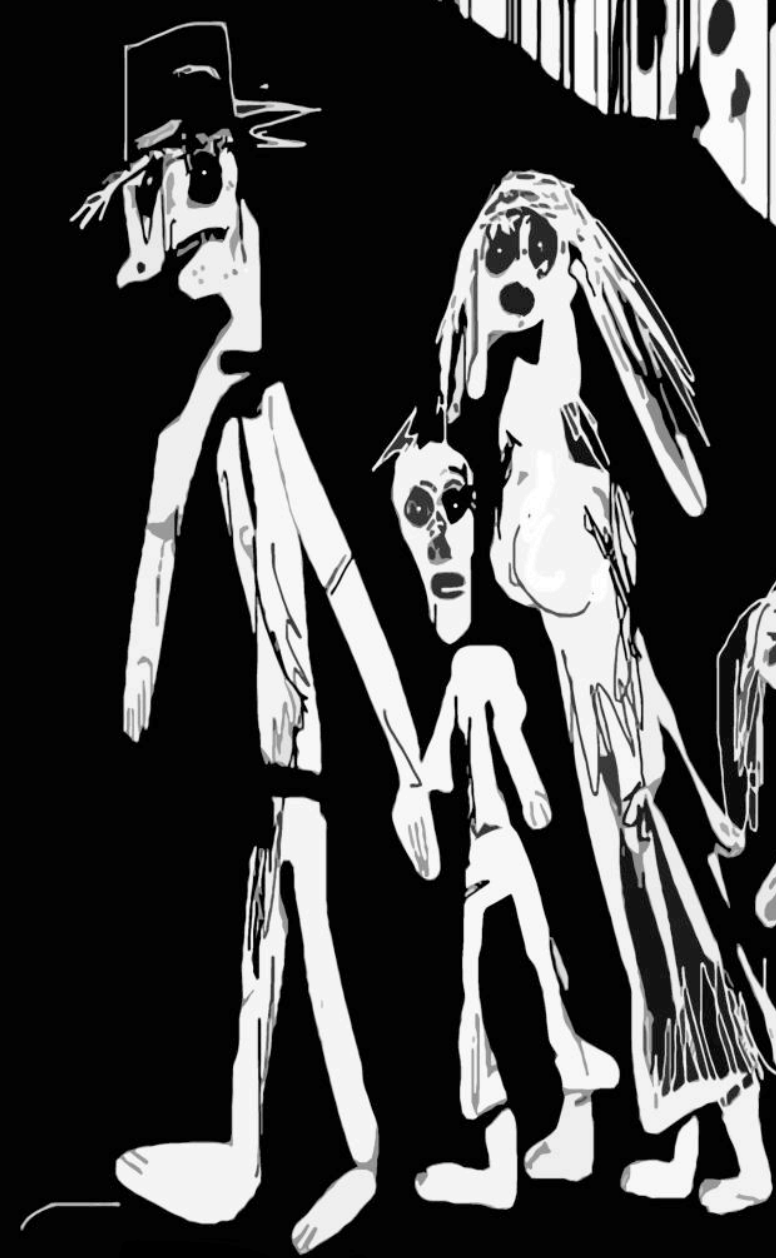

NACHO Carla 


\section{ACCESS, POWER AND JUSTICE IN COMMODITY FRONTIERS}

THE POLITICAL ECOLOGY OF ACCESS TO LAND

AND PALM OIL EXPANSION IN COLOMBIA

Victoria Marin-Burgos 


\section{Graduation committee:}

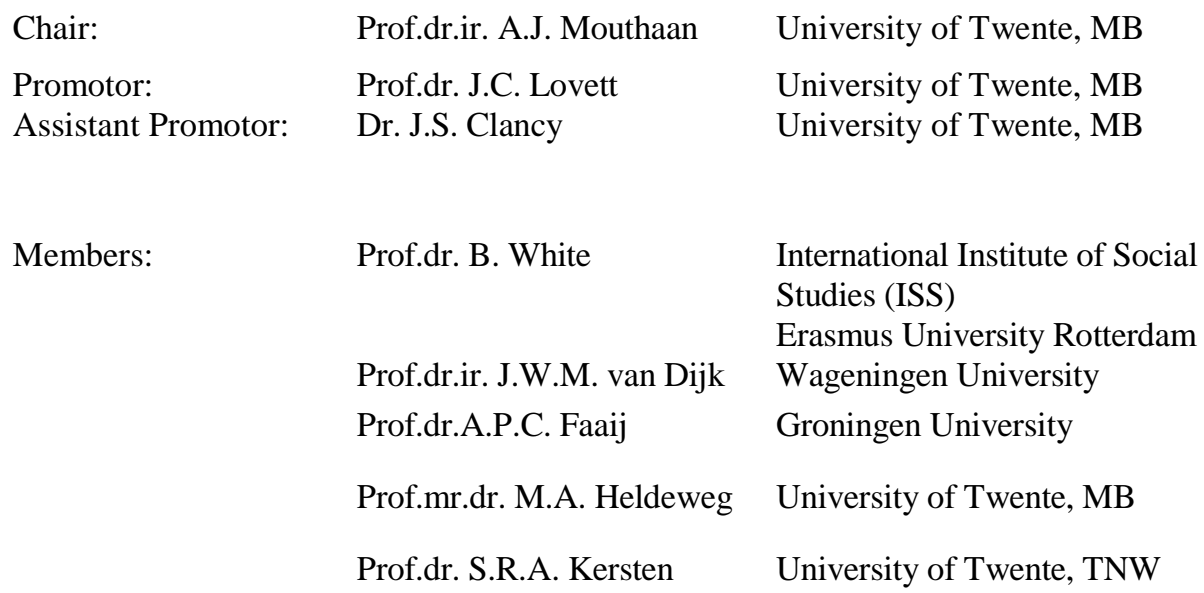

The work described in this thesis was performed at CSTM (The Twente Centre for Studies in Technology and Sustainable Development), Institute for Innovation and Governance Studies, Faculty of Management and Governance, University of Twente, PO Box 217, 7500 AE Enschede, The Netherlands.

Cover design: José Ignacio Cadena

Printed by: CPI - Koninklijke Wöhrmann, Zutphen

When referring to this dissertation, please consider the following citation:

Marin-Burgos, V. (2014). Power, Access and Justice in Commodity Frontiers. The political ecology of access to land and palm oil expansion in Colombia. PhD Thesis, University of Twente, Enschede, The Netherlands. http://dx.doi.org/10.3990/1.9789036536851.

Copyright (C) 2014, Victoria Marin-Burgos.

All rights reserved.

ISBN: 978-90-365-3685-1

URL: http://dx.doi.org/10.3990/1.9789036536851 


\title{
ACCESS, POWER AND JUSTICE IN COMMODITY FRONTIERS \\ THE POLITICAL ECOLOGY OF ACCESS TO LAND \\ AND PALM OIL EXPANSION IN COLOMBIA
}

\author{
DISSERTATION
}

to obtain

the degree of doctor at the University of Twente,

on the authority of the rector magnificus,

Prof. dr. H. Brinksma,

on account of the decision of the graduation committee,

to be publicly defended

on June 20th, 2014 at 12.45 hours

by

Victoria Marin-Burgos

born on July 10th, 1976

in Medellín, Colombia 
This dissertation has been approved by:

Promotor: Prof. dr. Jon C. Lovett

Assistant promotor: Dr. J.S. Clancy 


\section{Table of Contents}

Table of contents

List of Tables, Figures, Boxes, Pictures and Maps

List of Abbreviations and Acronyms

Acknowledgements

i

$\mathrm{V}$

ix

$\mathrm{xi}$

\section{Chapter 1. Introduction}

1.1. Background

1.2. Problem statement and research questions

1.3. The 2000-2010 expansion of the palm oil frontier in Colombia as a case study

1.4. Outline of the thesis

Chapter 2. Conceptual, Epistemological and Methodological Underpinning 11

2.1. Introduction 11

2.2. Conceptual background: political ecology and resource access struggles 12

2.2.1. Local-global and agency-structure interactions shaping resource access struggles in commodity frontiers

2.2.2. Actors' power relations in resource access struggles 21

2.2.3. Socio-environmental conflicts and environmental justice 25

2.2.4. Socio-environmental conflicts and sustainability governance 27

2.3. Epistemological underpinning 29

2.3.1. Epistemologies of the South 29

2.3.2. The reflexive model of science $\quad 30$

2.4. Research design and methodology 33

2.4.1. Case study research and the 'extended case method' 33

2.4.2. Caveats 40

2.4.3. Reflexivity 43

Chapter 3. Trajectories of Expansion of the Palm Oil Frontier in Colombia: Markets, Places, Land Control and Resistance $\quad 51$

3.1. Introduction 51

3.2. Conceptual and analytical framework: trajectories of commodity frontiers expansion and land control $\quad 54$

3.3. Overview of the expansion of the palm oil frontier in Colombia 59

3.4. Trajectories of the 2000-2010 expansion of the palm oil frontier in Colombia 
3.4.1. The 'space-of-flows': markets, 'flex-crops' and biofuels

3.4.2. The 'space-of-place': oil palm 'crop boom' and trajectories of land control and resistance

3.5. Conclusions

Chapter 4. Governmental Support, Power and Access to Resources: Access to Land and Governmental Support to the Palm Oil Agro-industry in Colombia 103

4.1. Introduction

4.2. Conceptual and analytical framework: the theory of access and access analysis

4.3. Governmental support to the palm oil agro-industry and access to land in Colombia

4.3.1. Contemporary governmental support to the palm oil agro-industry in context

4.3.2. Governmental support, structural mechanisms of access and access to land

4.3.3. Governmental support and access to authority

4.4. Conclusions

Chapter 5. Expansion of Commodity Frontiers, Dimensions of Justice and Human Rights: Justice and Resistance in the Context of the Expansion of the Palm Oil Frontier in Colombia

5.1. Introduction

5.2. Analytical and conceptual framework: expansion of commodity frontiers, resistance, livelihoods and justice

5.3. Material and methods

5.4. Expansion of the palm oil frontier and dimensions of justice in three cases of resistance in Colombia

5.4.1. The context: the expansion of the palm oil frontier in the Central Region of the palm oil geography

5.4.2. The cases

5.4.3. The livelihood and justice dimensions of resource access struggles and the emancipatory potential of human rights

5.5. Conclusions 


\section{Chapter 6. Contesting Legitimacy of Non-state Market-driven Sustainability}

Governance: Local Valuation Languages, Procedural Power and the Roundtable on Sustainable Palm Oil in Colombia

173

6.1. Introduction

6.2. Legitimacy, plurality of values and 'procedural power' in NSMD sustainability governance

6.3. Legitimacy contestation of the RSPO in Colombia

6.4. Actors and values in oil palm socio-environmental conflicts and the legitimacy of the RSPO in Colombia

6.5. Whose values, whose power in the Colombian National Interpretation of the RSPO Principles and Criteria

6.6. Conclusions

Chapter 7. Conclusions

7.1. Introduction

7.2. Conclusions from the empirical chapters

7.2.1. Interactions between global expansion of commodity frontiers, and country-specific trajectories of expansion and resource access control

198

7.2.2. Governmental support to extractive industries and power relations shaping access to resources

7.2.3. Justice dimensions involved in the expansion of commodity frontiers and emancipatory potential of human rights politics

7.2.4. Legitimacy contestation of non-state market-driven (NSMD) sustainability governance systems at the national scale

7.2.5. How is the expansion of commodity frontiers manifested in country-specific trajectories of inequitable resource access?

203

7.3. Contributions to knowledge and practice 205

7.3.1. Contributions to knowledge 205

7.3.2. Political relevance in lieu of policy recommendations 208

\begin{tabular}{ll} 
7.4. & Areas for future research \\
\hline
\end{tabular}

Epilogue: Overview of Country-specific Trajectories of Expansion of the

Palm Oil Frontier in Colombia after 2010

\section{Appendices}

Appendix A - List of interviews and meetings during fieldwork in Colombia

Appendix B - Details of the cases of 'accumulation by dispossession' presented in Chapter 3 
Appendix C - Details of the palm oil agro-industry 'privileged access to the government'

References

Summary

Resumen (in Spanish)

Samenvatting (in Dutch)

275

About the Author

281 


\section{List of Tables, Figures, Boxes, Pictures and Maps}

\section{List of Tables}

Table 2.1. Principles of positive and reflexive models of science, and context and power effects in the research practice

Table 2.2. Application of the 'extended case method' to the case study on resource access struggles and the 2000-2010 expansion of the Palm oil frontier in Colombia

Table 2.3. Research design

Table 3.1. Commodity chain integration of seven major palm oil producers in Colombia in 2010

Table 3.2. Commodity chain integration of palm oil producers involved in biodiesel production in 2010

Table 3.3. Large-scale palm oil producers controlling most of the oil palm Cultivation under 'productive alliances' in 2010

Table 3.4. Cases of 'accumulation by dispossession' connected with the 2000-2010 expansion of the palm oil frontier in Colombia

Table 4.1. Instruments of governmental support for the palm oil agro-industry along the commodity chain and the structural mechanisms of access they represent

Table 4.2. Allocation of governmental support that provides access to capital for the palm oil agro-industry and other agricultural sub-sectors (2002-2010)

Table 4.3. Allocation of access to knowledge and technology governmental support for the palm oil agro-industry

Table 4.4. Implementation of the biodiesel blending mandate in Colombia

Table 4.5. Families, individuals and organizations in the palm oil agro-industry connected with the government and beneficiaries from governmental support

Table 5.1. Details of the cases of 'accumulation by dispossession' and 'assimilation' selected for the analysis in Chapter 5

Table 6.1. Socio-environmental conflicts connected with the 2000-2010 expansion of oil palm cultivation in Colombia

Table 6.2. Oil palm producer towns and hectares planted per region

Table A.1. List of interviews and group meetings during exploratory fieldwork in Colombia, January - February 2010

Table A.2. List of interviews and group meetings during fieldwork in Colombia, August - December 2011 
Table B.1. Details of the cases of 'accumulation by dispossession' presented in Table 3.4 in Chapter 3

Table C.1. Details of the flow of individuals moving to work from government to Fedepalma and vice versa

Table C.2. Families, individuals and organizations in the palm oil agro-industry connected with the government and beneficiaries from governmental support

Table C.3. Members of families in the palm oil agro-industry connected with the governments of Álvaro Uribe Vélez and Juan Manuel Santos 


\section{List of Figures}

Fig. 3.1. Analytical and conceptual framework: commodity metabolism for the study of country-specific trajectories of commodity frontiers expansion 58

Fig. 3.2. Oil palm cultivation in Colombia (hectares planted) 1970-2012 59

Fig. 3.3. National and international crude palm oil prices January 1981- January $2004 \quad 60$

Fig. 3.4. Colombian palm oil commodity metabolism 62

Fig. 3.5. Colombian palm oil production and sales per market of destination 1998-2010 64

Fig. 3.6. Colombian palm oil exports per regions of destination 2000-2010 71

Fig. 3.7. National and international crude palm oil prices 2000-2010 72

Fig. 3.8. EU biodiesel production, vegetable oils consumption and palm oil imports 2000-2010 73

Fig. 3.9. Rapeseed oil consumption for food and industrial use in the EU 2000-2010 74

Fig. 3.10. Colombian palm oil exports to EU per major markets of destination 2000-2009

Fig. 3.11. Characterization of land control practices of 'accumulation by dispossession' and 'assimilation' connected with the 2000-2010 expansion of the palm oil frontier in Colombia

Fig. 4.1. Amount of land devoted to new/renewal oil palm cultivation 1990-2012

Fig. 4.2. Amount of Finagro (agricultural) credit for oil palm cultivation/ maintenance, and distribution by type of oil palm grower 2000-2010

Fig. 4.3. Flow of individuals moving to work from government to Fedepalma and vice versa

Fig. 5.1. Analytical framework: interrelations between access, livelihoods, justice and human rights

Fig. 5.2. Interrelations between land access struggles connected with the expansion of the palm oil frontier in Colombia, dimensions of livelihood, dimensions of justice and human rights

Fig. 6.1. Conceptual Framework - Legitimacy, Valuation Languages and Procedural Power

Fig. 6.2. Timeframe of the Colombian RSPO P\&C NI process

Fig. 6.3. Comparison of invitees and attendees to regional workshops held for the Colombian RSPO P\&C NI

Fig. 6.4. Participation per sector of the attendees to the regional workshops held for the Colombian RSPO P\&C NI 


\section{List of Boxes}

Box 4.1. Excerpts from the National Development Plans of Andrés Pastrana's and Álvaro Uribe Vélez's governments

\section{List of Pictures}

Picture 5.1. Photographs of landscapes of agro-industrial oil palm plantations 145

Picture 5.2. Photographs of landscapes of typical peasants farms

\section{List of Maps}

Map 3.1. Changes in the geography of the palm oil frontier in Colombia between 1999 and 2010

Map 3.2. Geography of internal displacement between 1998 and 2006 in the palm oil frontier in Colombia

Map 5.1. Geographical localization of the cases analysed in Chapter 5 


\section{List of Abbreviations and Acronyms}

AIS

ASOBENPRO

ASOCAB

ASOCOL

ASOPRODAGRO PC

CDPMM

CENIPALMA

DNP

ERC

EU

FEDEPALMA

FFB

$\mathrm{IAvH}$

ICR

$\mathrm{I} \& \mathrm{D}$

INCODER

LEC

MADR

MAVDT

NGOs
Agro Ingreso Seguro Programme

Asociación de Beneficiarios del Proyecto the Palma El Progreso

Asociación de Campesinos de Buenos Aires

Asociación Colombiana Horizonte de Población

Desplazada

Asociación de Productores Agropecuarios y Agrícolas del Corregimiento de Puerto Carreño

Corporación Desarrollo y Paz del Magdalena Medio

(Corporation Development and Peace of the

Magdalena Medio)

Centro Corporación de Investigación de la Palma de Aceite (Oil Palm Research Centre)

Departamento Nacional de Planeación

(National Planning Department)

Exchange Rate Risk Coverage

European Union

Federación Nacional de Cultivadores de Palma de Aceite

(National Federation of Oil Palm Growers)

Oil palm fresh fruit bunches

Instituto de Investigación de Recursos Biológicos

Alexander von Humboldt

(Alexander Von Humboldt Institute for Research on Biological Resources)

Incentivo de capitalización rural

(Rural Capitalisation Incentive)

Irrigation and Drainage (subsidy)

Instituto Colombiano de Desarrollo Rural

(Colombian Institute for Rural Development)

Línea Especial de Crédito

(Special line of credit with subsidised interest rate)

Ministerio de Agricultura y Desarrollo Rural

(Ministry of Agriculture and Rural Development)

Ministerio de Ambiente, Vivienda y Desarrollo Territorial

(Ministry of Environment, Housing and Territorial

Development)

Non-governmental organizations 
NI

NSMD

OCMAL

RSPO

RSPO P\&C

TFZ

$\mathrm{UAF}$

UK

USAID

VAT

WWF
Colombian National Interpretation of the RSPO P\&C

Non-state market-driven

Observatorio de Conflictos Mineros de América Latina (Latin American Observatory of Mining Conflicts)

Roundtable on Sustainable Palm Oil

RSPO Principles and Criteria

Tax Free Zone(s)

Unidad Agrícola Familiar

(Family Agricultural Unit)

United Kingdom

United States Agency for International Development

Value added tax

World Wildlife Fund 


\section{Acknowledgements}

"When you set out for Ithaka ask that your way be long, full of adventure, full of instruction...

Have Ithaka always in your mind. Your arrival there is what you are destined for. But don't in the least hurry the journey. Better it last for years, so that when you reach the island you are old, rich with all you have gained on the way, not expecting Ithaka to give you wealth. Ithaka gave you a splendid journey. Without her you would not have set out. She hasn't anything else to give you. And if you find her poor, Ithaka hasn't deceived you. So wise you have become, of such experience, that already you'll have understood what these Ithakas mean."

(Constantine P. Cavafy)

Here I am writing the acknowledgements, the last piece of the thesis. This means that my $\mathrm{PhD}$ journey is over. This Ithaka has not deceived me. It has been a splendid journey "full of adventure, full of instruction", and I have become richer with all what I received from the people that I have encountered on the way.

First and foremost, I want to thank the people I met in San Alberto and Sabana de Torres during my fieldwork, for being open to share their stories and helping me to get my way around in their territories. They unveiled to my eyes the paradoxes of the rural life in Colombia. Their struggles and endurance have been a great source of inspiration, the reason that kept me going in those moments in which I thought I could not finish this project. I have to thank specially Evaristo and Elíder; without their help my field visits to San Alberto and Sabana de Torres would not have been possible. Primero que todo quiero agradecer a las personas que conocí en San Alberto y Sabana de Torres durante el trabajo de campo por ayudarme a orientarme en sus territorios y compartir sus historias. Ellos abrieron mis ojos a las paradojas de la vida rural en Colombia. Su lucha y tenacidad han sido una gran fuente de inspiración, el motivo para seguir adelante en aquellos momentos en los que pensé que no lograría culminar este proyecto. Gracias especialmente a Evaristo y Elíder; sin su ayuda y disponibilidad mis visitas de campo a San Alberto y Sabana de Torres no habrían sido posibles.

I owe many thanks to my supervisor Joy Clancy and my promotor Jon Lovett.

Joy, I want express all my gratitude for your advice, guidance and support. I have learnt a 
lot from what your "'grey hairs" transmitted to me, even though it often seemed that I was not listening. I am very grateful for your support in the most difficult moments, especially in the last months of the thesis writing. What I have learnt from you goes beyond theory and methods. You have been a great inspiration as a scientist and as a woman.

Jon, I thank you for guiding me so patiently in spite of my obstinate character. I really appreciate that although we have a different approach to science, you did not impose yours and were open to discuss and accept mine as long as I was able to defend it with strong arguments. In this way you really made me think critically about myself as a scientist.

I want to thank the organizations, individuals and friends that helped me during the fieldwork in Colombia. Quiero agradecer a las organizaciones, individuos y amigos que me prestaron su ayuda y colaboración durante el trabajo de campo en Colombia.

I thank the organizations and persons I worked with during the exploratory fieldwork Grupo Semillas, and Cinara Institute, in particular Paula Álvarez and Lina Forero (Grupo Semillas), Mario Alejandro Pérez and Paola Arias (Cinara Institute). I also want to thank Miriam Villegas (who at the time of the exploratory fieldwork was part of the Corporation Development and Peace of the Magdalena Medio - CDPMM) for facilitating the contacts for the field visit to the Magdalena Medio region during the exploratory fieldwork.

Agradezco a las organizaciones y las personas con quienes trabajé durante el trabajo de campo exploratorio - Grupo Semillas e Instituto Cinara, en particular Paula Álvarez y Lina Forero (Grupo Semillas), Mario Alejandro Pérez y Paola Arias (Cinara Institute). También quiero agradecer a Miriam Villegas (quien al momento del trabajo de campo exploratorio estaba vinculada a la Corporación Desarrollo y Paz del Magdalena Medio) por facilitar los contactos para la visita de campo al Magdalena Medio durante el trabajo de campo exploratorio.

I also thank the Netherlands Organisation for Scientific Research (NWO). The stakeholder consultation funded by NWO (CoCooN programme) for the preparation of the research proposal named "Agrofuels, a recipe for conflict? The case of Colombia from a global to local perspective" constituted the exploratory fieldwork of this thesis.

I thank Corporación Obusinga (in particular Néstor Mendieta) and Corporación Compromiso for helping me to establish key contacts in the field sites during the second period of my fieldwork. I am very grateful to Elizabeth Ruiz. Her help was crucial to establish contact with key informants, and with the local leaders in San Alberto and Sabana de Torres. Elizabeth's dedication to agrarian justice in Colombia and her work in favour of rural communities have been of great inspiration.

Agradezco a la Corporación Obusinga (en particular a Néstor Mendieta) y a Corporación Compromiso por ayudarme a establecer contactos clave durante el segundo trabajo de 
campo. Estoy muy agradecida con Elizabeth Ruiz, su ayuda fue crucial para establecer contacto con informantes clave y con líderes locales en San Alberto y Sabana de Torres. Su dedicación a la justicia agraria en Colombia y su trabajo en favor de comunidades rurales han sido una gran fuente de inspiración.

Gracias a los amigos que me abrieron las puertas de sus casas en Bogotá durante mis largas estadías a la espera de entrevistas. Gracias a mi amiga María Orrego y su mamá Gloria, hicieron de su casa mi casa, me acogieron como si fuera de la familia, y me enseñaron algo de lo que me he enamorado: tejer para ejercitar la paciencia. Gracias a mis amig@s Nathalie, Solmarina y Rafa quienes también me dieron hospedaje, amor y apoyo durante mis pasos por la capital. Gracias a Nacho y Mónica por acogerme en su casita en el hermoso campo caleruno y por quererme tanto, especialmente en los momentos más duros del trabajo de campo. Nacho, tu arte en la portada de esta tesis es un orgullo. No tengo palabras para agradecerte.

I also want to thank the people in a port I stopped by during this journey that was very important to me: Barcelona. From my three-month research visit at ICTA - Autonomous University of Barcelona I met wonderful people and I gained much of the scientific knowledge I needed to finish this thesis. All what is written in this dissertation has the imprint of what I have learnt during this research visit. I am very grateful to Professor Joan Martinez-Alier for welcoming me at ICTA and for his insights and advice about the topic of this dissertation. I owe many thanks to Mariana Walter for helping me to arrange the visit and being a great host. I also want to thank all the friends who made of my stay in Barcelona an unforgettable experience. Gianluca and Laura, I do not have words to thank you for opening the doors of your house so generously. Laura, I keep remembering our series-watching nights and the Venezuelan (and one Colombian) gatherings. Paola Arias, Andrea Botero, Jose Toro y Ana Vélez, ustedes fueron mi tierra en tierra catalana. A 1@s chic@s de la sala en ICTA - Ardi, Dídac, Eli, Luís, Marta García, Sara Maestre, Mariana, Pere, Leah y Bea - gracias por los buenos momentos, las canciones del día, los cafés, los almuerzos, las cañas a la salida y la cena de despedida. Ardi, Eli, Dídac, Marta García y Luís fue genial conocerlos, gracias por la compañía, los paseos y las salidas en Barcelona. Siempre aparecen sus caras en mis mejores recuerdos de Barcelona.

In the Netherlands, where I have stayed the longest during this journey, I have encountered wonderful people.

At the CSTM I met very good friends and colleagues. Gul, it was great to share the office with you and build a friendship that goes from having scientific discussions about political ecology to coffee reading, passing through conversations about the ups and downs of being ex-pats in the NL and learning how to cook Turkish food. Hazel, you always had a loud 
smile to share with me that brightened even the worst grey Dutch days; I am so glad I met you...wait for me to see the giraffes!. Nthabi, I could not have borne so many weekends and days working late at the office writing the thesis in summer without your company. Oh, our shared struggle writing the literature review! I am sure we will celebrate soon your $\mathrm{PhD}$. Sahar, you have been so nice and caring to me. I really thank you for sending emails and being in contact, even after long time I did not reply. Arturo, Vera and Maya, I really enjoyed our long chats in the office and your company in the dinners and events outside the office along these years. Ewert, thank you very much for your help translating the summary of this thesis into Dutch. Ada Krooshoop and Barbera van Dalm-Grobben thank you for all the logistical support throughout these years.

Thanks to all the friends that have made easier the difficult times of homesickness, and cold and dark days of the winter in the Netherlands.

The Colombian gang: Andrea, Edgar, Diego, Sergio, Mafe, Alejandro, Juan Carlos, Laura, Gonzalo and Margarita, gracias por estar presentes en las cenas, las fiestas, las conversadas y las reuniones para evocar juntos esa tierra que duele y se extraña tanto. Vivian Botero, que alegría que nos hayamos re-encontrado en Holanda para descubrir en vos una amiga que conocía pero desconocía.

Thanks to my very good friends Renuka and Anand for being so caring and loving. It is a gift to have friends as you are.

Clarita and Gustavo, a pesar de las diferencias que nos han alejado, quiero agradecerles por tener siempre las puertas de su casa abiertas cada vez que Lorenzo y yo queríamos escapar de Enschede. La pasamos muy bien. Siempre mantendré en mi memoria los buenos recuerdos.

Fabienne, you were the first face I saw when I arrived the first time in the Netherlands. I am very happy that ten years have passed and we are still friends.

Hugo and Ana. We had so many good moments together. The countless dinners we shared; the lovely holidays in Norway, and the multiple celebrations: your PhDs, the birthdays parties of Lorenzo and I, the happiness of knowing Bernardo was coming and when he was born. I am just grateful for your friendship... and of course for the multiple times you fed me when Lorenzo was away! We miss you a lot here in Enschede.

Shilpa, the best student of the "bomba". It was great to have somebody to share the anguish of the last stages of the PhD. The few coffees we had time to have together during that period of the thesis writing were cathartic. Now that we are done with our PhDs, let's dance "bomba" again.

Carla, gracias por tener la paciencia para escuchar mis lamentos a la hora del almuerzo, por las cenas, por salvarme a la hora del ajiaco para 15 personas!, por los bailoteos, por Inti y por el yoga que me ha salvado de los males que aquejan por las miles de horas sentada frente al computador escribiendo esta tesis. 
I miei carissimi amici Italiani Raffi, Andrea, Vanessa (detta Fanessa). Ci siamo divertiti tanto sin dalla prima lezione di "ostrogoto", grazie davvero per sopportare le mie infinite lamentele di ex-pat tropicale. Grazie di tutte le cene insieme e delle belle serate e le gite. Ragazzi ci mancherete tanto quando ci saremo trasferiti: vedete di trovare un lavoro in Limburg!

No puede faltarme el resto de la familia Latina: David, Kike, Fede, Lila, Paty, Olga, Andreea, Adriana, Julián, Rafa y Mariela, Chela, Roland e Iza, Diru y Juan, Daniela G. e Ignacio, Daniela F. y Oscar, Los Panas (Maite y Jorge), Naye y Eduardo. La vida en Enschede habría sido muy triste sino fuera por este familión.

Panas (Maite y Jorge), Dani y Oscar, Naye y Eduardo que nuestra amistad siga creciendo y multiplicándose tanto como las lechugas de nuestro huerto. Gracias por cuidarme tanto durante los tiempos mas oscuros (en sentido literal y figurado). A los panas Maite y Jorge, gracias por la buena amistad, por la compañía, la comida (sobretodo cuando Lorenzo no estaba), y por supuesto el buen ron. Gracias Dani y Oscar por la buena energía siempre, gracias por acordarse de mi en cada viaje a México y por compartir de cerca su más grande alegría: la espera y llegada de Lucio. Naye y Eduardo, me quedan cortas las palabras para agradecerles por los incontables gestos de cariño y amistad. Naye tu apoyo y compañía en la recta final de este viaje ha sido invaluable. Gracias por acompañarme la noche en blanco la víspera de la entrega de la tesis al comité y por sacrificar el único día de sol de la primavera, en ambos casos ayudándome con los famosos mapas. Naye, Gracias Totales!

No puedo dejar de agradecer a mis grandes amig@s de siempre Sandra, Carlos y Benjamín por hacerme sentir que han estado a mi lado a lo largo este viaje a pesar de la distancia. Gracias por la infinita paciencia que han demostrado al escuchar una y mil veces mis eternos discursos sobre el tema de esta tesis, y ahora les va a tocar leerla!

Grazie alla mia famiglia italiana (Gigliola, Alberto, Luca, Valeria, Elisa, Mauro e ragazzi) per il supporto e l'intersesse che avete mostrato per questo mio progetto. Grazie per avere sempre le braccia e il cuore aperti per me. Non ho parole per ringraziarvi per la vostra generosità.

To my parents, they gave me the best present a daughter can receive: they patiently made with incommensurable love the wings that would let me fly behind my dreams, no matter how painful the distance would be for them. To my brother, thank you for being my companion, you have always stood by me and I know you will continue to do so. Your presence in the graduation is one the best presents I have ever received. This thesis is also in homage to my grandmother Esther who kept her eyes on me from heaven to protect me during the fieldwork. 
A mis padres, quienes me dieron el mejor regalo que una hija puede recibir: pacientemente y con inconmensurable amor construyeron las alas que me permitirían volar detrás de mis sueños, a pesar de lo dolorosa que es para ellos la distancia. A mi hermano, gracias por ser mi compañero, siempre has estado a mi lado y se que así será también en el futuro. Tu presencia en mi graduación es uno de los mejores regalos que he recibido. Esta tesis es también un homenaje a mi abuelita Esther, quien desde el cielo mantuvo sus ojos sobre mi para protegerme durante el trabajo de campo.

Finally, all my love and gratitude to my beloved husband Lorenzo who has been next to me during the full journey keeping the boat afloat and the sails full. Lorenzo I fall short of words to express how grateful I am for your love, patience and support. I am looking forward to our next journey together. Questo viaggio non sarebbe stato così meraviglioso se non ti avessi avuto accanto. A te tutta la gioia di essere arrivati ad Ithaka. A te che sei il mio grande amore. 


\section{Chapter 1}

\section{Introduction}

\subsection{Background}

On January 4, 1994, 300.000 Ogoni people participated in a massive protest against Shell Oil activities and environmental destruction in Ogoni land in the Niger Delta in Nigeria.

On May 24, 2000, about 10.000 people, including residents and supporters, started a two-day demonstration to protest against the development of a gold mining project operated by a Canadian company in the town of Tambogrande, Piura, in Peru.

On April 4, 2011, about 80 peasant farmers, representing a community of 123 families, jointly returned to the land they were evicted from by the action of companies who had claimed the land to cultivate oil palm in the south of Bolívar, Colombia

What connects these stories arising from places very distant from each other and each with very different contexts is the struggle of local populations to defend the environments which provide the physical, social, cultural and economic bases upon which their lives and livelihoods depend. They are all snapshots of socio-environmental conflicts, i.e. disputes over access to resources and over the burdens of environmental impacts that are rooted in differences in values and inequalities in power among human groups (Escobar, 2006a and 2006b; Martinez-Alier, 2002).

Conflicts over natural resources are not a new phenomenon. They "are intrinsic to human development" (Bryant, 1992) and are an ever-present occurrence in human history. However, we are facing a phase of capitalist expansion in the post-1990s in which the expansion of commodity frontiers is unfolding at an unprecedented rate and scale. This sets the likely scene for a proliferation of socio-environmental conflicts (Muradian et al., 2012). The expansion of commodity frontiers is the process of "production and distribution of specific commodities, and of primary products in particular, that ha[s] restructured geographic spaces in such a way as to require further expansion" (Moore, 2000: 410). ${ }^{1}$

\footnotetext{
${ }^{1}$ Moore's notion of commodity frontiers expansion is based on a study of the global development and expansion of sugar production and trade between the fifteenth and the nineteenth centuries. By tracing the expansion of the sugar frontier over a long-term he demonstrates how commodity
} 
Several studies indicate a marked increase in the intensity of both physical and biological resource extraction since the middle 1990s, especially in the Global South, (Muradian et al., 2012; Svampa, 2011). For example, the area devoted to industrial tree plantations has increased about fourfold in the Global South in the past two decades (Overbeek et al., 2012). ${ }^{2}$ Likewise, the remarkable increase in mining-related investment in developing countries since the 1990s is indicative of the expansion of the mineral extraction frontiers in the Global South (Bebbington et al., 2008a and 2008b; Bebbington, 2012a; Bridge, 2004). Latin America's share of global investment increased from 12 per cent in 1990 to 33 per cent by 2000 (Bebbington et al., 2008b).

This extraction path has led to a growing number of struggles in which access by "socially disadvantaged groups" (Bryant, 1992) to the environments that constitute the basis of their livelihoods and culture is defended against under threat from the interests of powerful actors pursuing different and often conflicting forms of use and exploitation (Bryant, 1992; Escobar, 2006a; Martinez-Alier, 2002). Thus, the origin of these struggles reflects the power relations that shape access to resources. On the one hand, companies and governments involved in the expansion of commodity frontiers are often in a position of power to control access to resources (Bebbington et al., 2008a; Bebbington, 2012a; Martinez-Alier, 2002). On the other hand, local populations resort to different strategies of resistance to counteract the power exerted by companies and governments to protect their livelihoods.

The number of conflicts connected with mining activities and tree plantations that have started in the last two decades illustrates the proliferation of socio-environmental conflicts elicited by the expansion of commodity frontiers. The records of the Latin American Observatory of Mining Conflicts (OCMAL) show that there were more than 198 active mining conflicts in the region in January 2014 (OCMAL, 2014). ${ }^{3}$ Most of these conflicts started in the 2000s (Özkaynak et al., 2012). Gerber (2011) and Özkaynak et al. (2012)

\footnotetext{
production and trade elicit socio-environmental transformations in such a way that they result in destabilisation of local ecosystems, land depletion, forest clearance, increase in the size of farms, local people displacement. As a consequence, geographical expansion is required in order to maintain production (Moore, 2000).

${ }^{2}$ Gerber (2011) uses the term 'Industrial Tree Plantations' to refer to "large-scale monocultures of tree crops - mainly eucalypts, pines, rubber tree and oil palm - that are managed intensively, which generally involves the use of agrochemicals, cloned or genetically modified trees, and short rotations in the case of wood-producing plantations. The purpose of such monocultures is to produce, as quickly as possible and at competitive prices, high volumes per hectare of typically one product, i.e. wood, rubber or palm oil" (Gerber, 2011: 165-166).

${ }^{3}$ The Observatory on Mining Conflicts in Latin America (Observatorio de Conflictos Mineros de América Latina) - OCMAL is an initiative of more than 40 Latin American organizations engaged in activism against the negative socio-environmental impacts of mining activities in the region.
} 
provide a comprehensive review of the socio-environmental conflicts resulting from the expansion of industrial tree plantations.

Latin America is one region experiencing a strong expansion of commodity frontiers since the middle 1990s (Bebbington, 2012a; Bebbington and Bury, 2013; Svampa, 2011). As Bebbington points out, there is a "set of continent-wide initiatives to open up frontiers for the extraction of hydrocarbons and metals, production of biofuels, harvesting of timber and investment in agro-industry...[I]n large parts of the continent peoples and environments are increasingly being pressured from all sides" (Bebbington, 2012b: 9). Svampa (2011) refers to this Latin American extractivist trend as the 'commodities consensus'. ${ }^{4}$ This 'commodities consensus' has not gone uncontested; it has given rise to numerous socioenvironmental conflicts and witnessed strong social mobilisation and resistance (Bebbington, 2012a; Bebbington and Bury, 2013; Svampa, 2008).

In this dissertation, I focus on the expansion of the palm oil frontier in Colombia and the processes of resistance and conflict connected with it. The expansion of commodity frontiers in Colombia mirrors the Latin American dynamics of extraction and resistance. The Atlas of Environmental Justice prepared by the Ejolt Project reports 72 socioenvironmental conflicts in Colombia in 2014. Fifty of these 72 conflicts are connected with extractive industries. ${ }^{5}$

Palm cultivation and palm oil production represent one of the commodity frontiers that have experienced a remarkable expansion and contestation since $2000 .{ }^{6}$ Indeed, I was inspired to embark in this research project when I came across a video that portrayed the effects on local communities of the accelerated expansion of oil palm cultivation in Colombia. The video captured testimonies of several families recounting their lives since oil palm

\footnotetext{
${ }^{4}$ Svampa uses the word 'consensus' to emphasise that the model of an economy based on extraction of primary commodities has been generally embraced by Latin American governments regardless their ideological orientation. Svampa points out that progressive governments that question the neoliberal model (for example Rafael Correa in Ecuador and Evo Morales in Bolivia), as well as governments that continue a conservative political agenda within the neoliberal framework (for example, Álvaro Uribe Vélez in Colombia and Alan García in Peru), have embraced the model of an economy based on extraction (Svampa, 2011).

${ }^{5}$ The Ejolt Project (Environmental Justice Organisations, Liabilities and Trade) is an European Union funded project that brings together academics and activist working on the field of environmental justice across different countries. The Ejolt Atlas is available at: http://ejatlas.org/ (Accessed March 20, 2014).

${ }^{6}$ In this dissertation I use the term oil palm to refer to the tree and differentiate it from the oil extracted from its fruits, i.e. the palm oil. The difference is relevant because not all oil palm growers are palm oil producers. However, when I refer to the palm oil frontier it encompasses both oil palm cultivation and palm oil production. Likewise, when I refer to the palm oil industry or agro-industry, it includes both palm growers and palm oil producers.
} 
cultivation had arrived to their region. The experiences these families described were not stories of a 'promising' life. They were about grievances and dispossession.

As I sought more information, further stories about grievances and socio-environmental conflicts started to emerge; not only in connection with the expansion of oil palm cultivation, but also with the expansion of other commodity frontiers, such as gold, coal, oil and sugar. Being a lawyer from Colombia, I was touched greatly by the injustices portrayed in these stories, so much so that I developed a personal interest to contribute to social and environmental justice by doing this research on the expansion of extractive activities and the situation of those people affected by such activities.

Such was the source of my interest to undertake this research on the topic of socioenvironmental conflicts connected with the expansion of commodity frontiers. It also explains the focus of this dissertation on the palm oil frontier in Colombia and the conflicts connected with its expansion.

\subsection{Problem statement and research questions}

The accelerated expansion of "commodity frontiers" is one manifestation of the current dynamics of global capitalism (Muradian et al., 2012: 561). However, country-specific geographies and their social, political and economic processes shape the ways in which the expansion of a specific commodity frontier unfolds in any particular country.

In this thesis, I use the concept of 'country-specific trajectories of commodity frontiers expansion' to refer to the specific ways in which the expansion of commodity frontiers unfolds in a particular country. Country-specific trajectories entail different practices to gain, control or maintain access to resources. Often these practices are shaped by governmental incentives to support the extractive activities and, hence, these incentives define the power asymmetries between actors in their access to resources.

Country-specific trajectories also encompass the different responses from local actors situated in the places where expansion takes place. In many cases, these responses take the form of struggle and contestation in people's defence of their livelihoods. This is so because frontier expansion involves socio-ecological changes along different processes of the commodity chain - from extraction (the extraction frontiers) to disposal - that can threaten local people's livelihoods.

Contestation and conflict are signs of, and responses to, the injustices enmeshed in such 
threats (Martinez-Alier, 2013). ${ }^{7}$ The socio-environmental concerns at the core of conflict and contestation often are addressed institutionally through governance mechanisms. Nonstate market-driven (NSMD) governance mechanisms, such as voluntary certification schemes, have become one of the global governance mechanisms commonly used to address the socio-environmental concerns associated with the expansion of agro-industrial commodities extraction, like palm oil.

However, the processes of adoption and implementation of the certification standards at the national scale often constitute arenas where contestation occurs, thereby challenging the legitimacy of the governance system is challenged. ${ }^{8}$ Legitimacy contestation may be rooted in: i) the different values of the local actors vis-à-vis the values that the governance system represents, and ii) decision-making procedures not taking into account such plurality of values. This is why local actors, who dispute the expansion of commodity frontiers, resort to different strategies outside of NSMD governance systems to articulate their resistance.

Human rights politics is used frequently as a strategy of resistance alongside other strategies (Martinez-Alier, 2002; Schlosberg, 2007). This reliance on human rights politics as a strategy of resistance can be explained by the fact that the human rights framework encompasses the different dimensions of justice that underlie the claims of resisting actors: i.e. the distribution of access to resources; recognition of difference in identity and culture; equal participation; and, freedom to pursue the lives people value to lead (Schlosberg, 2007). ${ }^{9}$

Thus, in the analysis of country-specific trajectories of expansion of commodity frontiers, important elements include the factors that influence the legitimacy contestation of NSMD sustainability governance systems at the national scale, as well as local actors' strategies of resistance and their potential for emancipatory politics.

\footnotetext{
${ }^{7}$ A commodity chain can be defined as "sets of interorganizational networks clustered around one commodity or product, linking households, enterprises, and states to one another within the worldeconomy" (Gereffi et al., 1994: 2).

${ }^{8}$ NSMD governance mechanisms operate within broader NSMD governance systems. A NSMD governance system encompasses the entire institutional apparatus underlying the adoption and implementation of a NSMD governance mechanism, which includes the NSMD governance mechanism itself.

${ }^{9}$ I use the term human rights politics to refer to political action that includes: framing claims in human rights terms, rendering them visible to human rights organizations, trying to influence institutional change through networking, advocacy and lobbying, and bringing cases before the human rights jurisdiction at national and supranational levels (Asian, African, Inter-American and European human rights systems that include commissions and courts).
} 
The main objective of this thesis is to provide new insights into how the expansion of commodity frontiers is manifested in country-specific trajectories of resource access, control and contestation. The aim is twofold:

Firstly, from an academic point of view, I aim to contribute to a better understanding of the underlying socio-economic and political processes and dynamics of conflict and contestation connected with the global expansion of commodity frontiers.

Secondly, through the knowledge generated, I aim to contribute to the strengthening of the arguments and claims of individuals, communities, organizations (e.g., grassroots organizations and NGOs) and state structures (e.g., governmental agencies, judges and ombudsman offices) engaged with the protection of local people whose livelihoods are affected (actually or potentially) by the expansion of commodity frontiers.

Based on this objective and these aims, the overarching research question addressed in this dissertation and the research sub-questions in which it unfolds are:

\section{Overarching Research Question:}

How is the expansion of commodity frontiers manifested in country-specific trajectories of inequitable resource access?

Research Sub-question 1: How does the global expansion of commodity frontiers interact with national geographies and socio-economic and political processes to produce countryspecific trajectories of expansion and resource access control? (Chapter 3).

Research Sub-question 2: How do governmental incentives to support extraction activities mediate power asymmetries among actors in access to resources? (Chapter 4).

Research Sub-question 3: How are the dimensions of justice threatened in practice and defended through the politics of human rights in cases of local resistance connected with the expansion of commodity frontiers? (Chapter 5).

Research Sub-question 4: How do power asymmetries among local actors and differences in values deployed in national standard-setting processes influence legitimacy contestation of NSMD sustainability governance systems at the national scale? (Chapter 6).

I address these research questions by analysing from a political ecology perspective the case of the expansion of the palm oil frontier in Colombia between the years 2000 and 2010 and the resource access struggles and contestation connected with this expansion. The study 
draws on data collected during two periods of fieldwork in Colombia and from an extensive review of secondary sources. The first period of fieldwork was carried out between January and February of 2010. The second period was carried out between August and December of 2011.

\subsection{The 2000-2010 expansion of the palm oil frontier in Colombia as a case study}

The pace and scale of the global expansion of the palm oil frontier across countries with very different contexts make a good setting in which to study country-specific trajectories of commodity frontiers expansion. The global palm oil market has experienced a remarkable boom since the year 2000. Global production increased between 2000 and 2010 from 21.8 million tonnes in 2000 to 45.8 million tonnes in 2010 (Oil World, 2001 and 2011).

The rise in palm oil production has led to an accelerated (actual or planned) expansion of oil palm cultivation in producing countries. This raises questions about the resulting socioenvironmental impacts at the local level. A wide range of articles and reports from nongovernmental organizations (NGOs) and the media, as well as empirical academic research, have documented potential and actual negative effects of oil palm expansion which, in some cases, have resulted in socio-environmental conflicts (Colchester et al., 2006; Friends of the Earth et al., 2008; Julia and White, 2012; Mingorance, 2006; Sheil et al., 2009; The Rainforest Foundation UK, 2013; Wakker, 2005).

Palm oil production especially takes place in the Global South in tropical areas of Africa, Asia and Latin America where the appropriate agro-climatic conditions are found to grow the oil palm tree.

Indonesia, Malaysia, Thailand, Nigeria and Colombia are the world's five leading producers. As Indonesia and Malaysia account for about $85 \%$ of the global palm oil production (Abdullah, 2011), it is the expansion of the palm oil frontier in these countries that has caught most of the attention of the scholarship on the political economy/political ecology of the contemporary palm oil expansion (Cooke, 2002; Cramb and Curry, 2012; Julia and White, 2012; McCarthy, 2010; McCarthy and Cramb, 2009; Pye, 2010). There are only a few political ecology studies about contemporary expansion of the palm oil frontier in other producing countries (See for example Alonso-Fradejas, 2012 on the palm oil expansion in Guatemala, and Curry and Koczberski, 2009 in Papua New Guinea).

Colombia is a relevant case for analysing how the expansion of commodity frontiers manifests in country-specific trajectories of resource access control and contestation. It is 
one of the world's leading producing countries and the expansion of the frontier has been relatively large and accelerated between 2000 and 2010. The amount of land cultivated with oil palm almost tripled from 157,000 hectares in 2000 to 404,000 hectares in 2010 (Fedepalma, 2005 and 2011a). Moreover, the country has been repeatedly cited in negative terms in the literature dealing with the socio-environmental impacts of palm oil expansion (Mingorance, 2006; WRM, 2006; Álvarez, 2008).

Several cases of resource access struggles and socio-environmental conflicts have been reported by researchers, journalists, and non-governmental and grassroots organizations (Carvajal, 2012; Franco and Restrepo, 2011; Vargas et al., 2010). The level of unease arising from the expansion of palm oil cultivation in Colombia can be gauged by the fact that the former United Nations Special Rapporteur on the Right to Food (Jean Ziegler) included the advance of oil palm cultivation in Colombia as a case of special concern in terms of land appropriation and human rights violations in two of his reports (UN, 2007 and 2008).

The academic research related to the dynamics of expansion of the palm oil frontier in Colombia has focused on three aspects:

i) The assessment of land use change from a land cover perspective (Castiblanco et al., 2013).

ii) Specific local case-studies (Álvarez, 2009; Cárdenas, 2012; Carvajal, 2012; Franco and Restrepo, 2011; García Reyes, 2011; Goebertus, 2009; Gómez-López, 2010; Hurtado and Hernández-Salazar, 2010; Pérez Castro, 2012; Restrepo, 2004).

iii) The connection with either the biofuel policy and production (Coronado Delgado and Dietz, 2013; Mejía Alfonso 2010; Pérez-Rincón, 2008) or with the internal armed conflict (Franco and Restrepo, 2011; Ocampo Valencia, 2009; Segura, 2008).

These studies provide a rather fragmented view of the trajectories of expansion of the palm oil frontier in Colombia. In this dissertation, I pull these disparate threads together by exploring the trajectories of the contemporary expansion (2000-2010) of the palm oil frontier in a comprehensive and coherent way. I focus also on some specific cases of resistance and socio-environmental conflict.

\subsection{Outline of the thesis}

This thesis consists of seven chapters, including this Introduction (Chapter 1). 
Chapter 2 presents the conceptual, epistemological and methodological underpinning of this dissertation. It locates the research in the field of political ecology and hightlights the conceptual and analytical pillars of the political ecology research on socio-environmental conflicts that inform this dissertation. It also presents a review of the political ecology literature on resource access struggles and conflicts connected with the expansion of commodity frontiers.

On the basis of this review, the chapter pinpoints the weaknesses of this literature and the concepts and insights from other disciplines used in this thesis with an aim to overcome such weaknesses and enrich the analytical potential of political ecology. Chapter 2 also presents the epistemological orientation guiding the research and explains why it is in line with the political ecology approach adopted. Finally, the Chapter contains the research design and methodology based on the 'extended case method' (Burawoy, 1998a and 2009).

Chapters 3, 4, 5 and 6 address each sub-research question respectively based on the empirical analysis of the case of the expansion of the palm oil frontier in Colombia between 2000 and 2010.

Chapter 3 addresses Research Sub-question 1. Drawing on the case of the 2000-2010 expansion of the palm oil frontier in Colombia, I analyse how global expansion of commodity frontiers interact with national geographies and socio-economic and political processes to produce country-specific trajectories of expansion and control over access to land. The chapter presents a detailed analysis of the trajectories of expansion of the palm oil frontier in Colombia, together with the country-specific geographical, socio-economic and political factors that shape them. The empirical analysis is based on an analytical framework that positions the country-specific trajectories of frontier expansion within the two spaces of commodity frontiers identified by Moore (2000), i.e. the space-of flows (markets) and the space-of-place (localities). This analytical framework integrates concepts from political ecology, ecological economics and agrarian political economy. Some sections of this Chapter are included in a book chapter to be published in autumn 2014 (MarinBurgos, forthcoming 2014).

Chapter 4 addresses Research Sub-question 2. In this Chapter I explore how governmental support to the expansion of commodity frontiers mediates power asymmetries in access to resources. I do so by applying Ribot and Peluso's 'theory of access' (Ribot and Peluso, 2003) to the analysis of the policy environments that supported expansion of the palm oil frontier in Colombia between 2000 and 2010. Since such expansion is at the root of socioenvironmental conflicts over access to land, I explore how such policy environment enabled 
access to land; whose access was enabled and whose was hindered; and, how the beneficiaries were able to influence policy-making and implementation.

An earlier version of this Chapter was published as a book chapter in Spanish (MarinBurgos, 2013). Some sections of the current version are included in a book chapter to be published in autumn 2014 (Marin-Burgos, forthcoming 2014).

Chapter 5 addresses Research Sub-question 3. In this chapter I analyse how dimensions of justice are threatened in practice and defended through human rights politics in local cases of resistance connected with the expansion of commodity frontiers. This focuses on three of the local cases of resistance reported in Chapter 3. The empirical analysis carried out in this Chapter is based on an analytical framework which builds upon the interrelations between access to resources; a multi-dimensional notion of livelihoods (Bebbington, 1999 and 2004; Bebbington et al., 2008a); Schlosberg's pluralistic and multi-dimensional conceptualization of environmental justice (Schlosberg, 2007); and, human rights.

Chapter 6 addresses Research Sub-question 4. In this chapter I analyse how local actors' power asymmetries and differences in values deployed in national standard-setting processes influence legitimacy contestation of NSMD sustainability governance systems at the national scale. The analysis is based on an empirical study of the process of adoption of the national interpretation of the Principles and Criteria of the Roundtable on Sustainable Palm Oil (RSPO) in Colombia. The analytical framework used for the analysis combines a notion of legitimacy of NSMD governance systems rooted in critical sociology (Bernstein 2005 and 2011; Bernstein and Cashore, 2007) with the concepts of valuation languages and procedural power that come from the scholarship at the intersection between ecological economics and political ecology (Martinez-Alier, 2002). This chapter is based on a paper in press in the journal "Ecological Economics" (Marin-Burgos et al., 2014).

On the basis of the empirical findings, Chapter 7 presents the conclusions of this research with regard to each research question. It also summarises the contribution to knowledge and practice, as well as highlighting areas for future research.

The epilogue contains a brief update of the most relevant developments regarding the country-specific trajectories of the expansion of the palm oil frontier in Colombia after 2010 to the end of 2013. 


\section{Chapter 2}

\section{Conceptual, Epistemological and Methodological Underpinning}

\subsection{Introduction}

This Chapter presents the conceptual, methodological and epistemological underpinning of this study. I draw mainly upon political ecology scholarship to research how the expansion of commodity frontiers is manifested in country-specific trajectories of inequitable resource access.

The expansion of a commodity frontier involves socio-ecological changes and demands access to natural resources in different processes of the commodity chain - from extraction (the extraction frontiers) to disposal - that can threaten local people's livelihoods. ${ }^{1}$ I use the definition of commodity chain developed by Gereffi et al. (1994): "a commodity chain can be defined as a sets of interorganizational networks clustered around one commodity or product, linking households, enterprises, and states to one another within the worldeconomy" (Gereffi et al., 1994: 2). This notion of commodity chain builds upon Hopkins's and Wallerstein's definition, which is also the basis for Moore's concept of 'commodity frontier' used in this thesis. Hopkins and Wallerstein define a commodity chain as a "network of labor and production processes whose end result is a finished commodity" (Hopkins and Wallerstein, 1986: 159).

"Threatened livelihoods, linked to altered social and environmental conditions figure centrally in political ecology thinking" (Bryant, 1998: 88). Struggles of "peasants and other socially disadvantaged groups to protect the environmental foundations of their livelihood" (Bryant, 1992: 21) constitute one of the core subjects of political ecology research (Bryant and Bailey, 1997; Martinez-Alier, 2002; Peet and Watts 1996b; Robbins, 2004 and 2012; Watts and Peet, 2004). Political ecology research has laid the foundations to the understanding of the nature and dimensions of resource access struggles, as well as their connections with broader socio-economic, political, and environmental processes. This dissertation is strongly guided by the political ecology literature on socio-environmental conflicts and resource access struggles, as detailed in Section 2.2. In Section 2.2, I also pinpoint the weaknesses of this literature and the concepts and insights from other disciplines with the aim to overcome such weaknesses and to enrich the analytical potential

\footnotetext{
${ }^{1}$ In this thesis I use the terms 'local populations', 'local people' and 'local actors' interchangeably to refer to the inhabitants of the localities where physical expansion of commodity frontiers takes place (see Section 2.4.2 for some caveats about the use of these terms).
} 
of political ecology and this thesis. In particular, I use concepts developed by the scholarship at the intersection between political ecology and ecological economics. I also use theories of environmental justice and human rights and I draw on the literature related to legitimacy of non-state market-driven sustainability governance systems.

As Burawoy points out, methodological decisions are shaped by the model of science we, the researchers, are committed to, i.e. our epistemological orientation. Moreover, our commitments to a specific model of science "occur before and indeed govern the choice and definition of problems" (Burawoy, 1998b: 18).

In my case, the definition of the questions this research addresses and the research design and methodology are epistemologically informed by:

i) The reflexive model of science (Burawoy, 1998a and 2009), and

ii) The epistemologies identified by Boaventura de Sousa Santos as 'epistemologies of the South' (Santos, 2006 and 2012).

I present a brief explanation of these epistemological orientations in Section 2.3.

This research takes as a case study the expansion of the palm oil frontier in Colombia between 2000 and 2010, together with the resource access struggles connected with such expansion. Following the principles of the reflexive model of science, the study is methodologically guided by the 'extended case method' developed by Michael Burawoy (1998a and 2009). Section 2.4 presents the research design and methodology.

\subsection{Conceptual background: political ecology and resource access struggles}

I place this research in a political ecology perspective by linking resource access struggles to the local socio-environmental change resulting from the expansion of commodity frontiers. The point of departure is the idea that the struggles for resource access that local populations engage in to combat the expansion of commodity frontiers represent an 'environmentalism of the poor', i.e. struggles in defence of the natural resource-based livelihoods threatened by the socio-environmental transformations that commodity frontiers expansion brings about (Guha and Martinez-Alier, 1997; Martinez-Alier, 2002).

Socio-environmental conflicts constitute the political arena in which the 'environmentalism of the poor' is deployed. Such conflicts are disputes over access to natural resources and over the burdens of environmental impacts that are rooted in differences in values and inequalities in power among human groups (Escobar, 2006a and 2006b; Martinez-Alier, 
2002). The expansion of commodity frontiers may affect local populations' access to natural resources either through physical dispossession (i.e. eviction, displacement, locking out, relocation), or through the transformation of the environments that sustain their livelihoods (Martinez-Alier, 2002; Bebbington et al., 2008a).

Thus, access to resources is a central concept of this dissertation. I follow Ribot and Peluso's 'theory of access' (Ribot and Peluso, 2003) which provides conceptual and analytical tools for the study of access to resources. Ribot and Peluso define access as the "ability to benefit from things" (Ribot and Peluso, 2003: 155). Under Ribot and Peluso's theory, access is about all possible structural and relational means that shape the ability to derive benefit from things, i.e. the means to gain, control or maintain access. It considers means intended, not only to impart property rights, but also means "that are not socially sanctioned in any domain of law, custom or convention", such as structural forces, discursive manipulations, relations of production and exchange, and even socially and legally forbidden acts or means (Ribot and Peluso 2003: 156).

The concepts of 'access' and 'environmentalism of the poor' were developed in the field of political ecology. Socio-environmental conflicts are also a core theme of this field. This conceptual point of departure positions this research in a political ecology perspective and delimits its analytical boundaries in two ways:

First, the focus on threatened livelihoods places this study in "a field of conflict analysis that is different from the one addressed in the literature tackling the relationship between natural resources and the incidence of civil wars and other armed conflicts" (Muradian et al., 2012: 564). ${ }^{2}$

Second, because socio-environmental conflicts are understood in terms of differences in values and power between actors, this study is distinct from approaches that place scarcity at the roots of conflicts over natural resources (see, for example, Homer-Dixon, 1999).

Robbins describes the field of political ecology as empirical research-based explorations addressing "the condition and change of social/environmental systems, with explicit consideration of relations of power" (Robbins, 2012: 20). Political ecology is not a theory. It is an inter-disciplinary field with its origins in the 1970s and has evolved "drawing on many disciplines (geography, anthropology, ecology, ecological economics, environmental history, historical ecology, development studies, science and technology studies) and bodies

\footnotetext{
${ }^{2}$ Some examples of the literature on the relationship between natural resources and the incidence of civil wars and other armed conflicts are Berdal and Malone, 2000; Collier, 2000; Collier and Hoeffler, 2005; Gleditsch, 1998; Le Billon, 2001; and Ross, 2004.
} 
of theory (liberal theory, Marxism, post- structuralism, feminist theory, phenomenology, postcolonial theory, complexity and natural science approaches such as landscape ecology and conservation biology)" (Escobar, 2010: 91). It was born from the confluence between political economy and some ecology-oriented frameworks, such as cultural and human ecology (Escobar, 2010; Robbins, 2012). In Blaikie and Brookfield words, it "combines the concerns of ecology and a broadly defined political economy. Together this encompasses the constantly shifting dialectic between society and land-based resources and also within classes and groups within society itself" (Blaikie and Brookfield, 1987: 17). ${ }^{3}$

Despite the multiple, and sometimes contested, theoretical and epistemological approaches underpinning the broad political ecology scholarship, in general terms, "political ecology characterizes a kind of argument, text, or narrative, born of research efforts to expose the forces at work in ecological struggle and document livelihood alternatives in the face of change" (Robbins, 2012: 21). There is a shared understanding among political ecology scholars that resource access struggles are a core theme of the field (Bryant and Bailey, 1997; Leff, 2012; Martinez-Alier, 2002; Robbins, 2012; Watts and Peet, 2004). Leff (2012), for example, defines political ecology as "the study of power relations and political conflict over ecological distribution and the social struggles for the appropriation of nature" (Leff, 2012: 5).

Political ecology analyses socio-environmental conflicts, and more specifically resource access struggles, in light of:

i) the interplay between ecological, socio-economic and political processes shaping control over access to resources and the distribution of environmental 'goods' and 'bads', paying special attention to power relations (Blaikie and Brookfield, 1987; Bryant and Bailey, 1997; Martinez-Alier, 2002; Peet and Watts, 1996b; Peluso and Watts, 2001b; Watts and Peet, 2004), and

ii) the different values and meanings that determine the human-nature interactions of differentiated actors (Escobar, 2006a and 2006b; Martinez-Alier, 2002; Moore, 1993).

From a political ecology perspective, socio-environmental conflicts include a broad range of struggles involving different environmental resources, activities and social actors. The conflicts may be over access to resources (e.g. land, minerals, water, fisheries, trees or

\footnotetext{
${ }^{3}$ For a more detailed account of the debates, themes and approaches in the field of political ecology, as well as its origins and development, see Biersack, 2006; Blaikie, 1999; Bryant and Bailey, 1997; Escobar, 2010; Leff, 2012; Peet and Watts, 1996b; Robbins, 2004 and 2012; Rocheleau, 2008; Watts and Peet, 2004.
} 
forests) in connection with diverse activities (e.g. mining; agriculture; livestock breeding; oil extraction; shrimp farming; commercial fishing; infrastructure projects; or, nature conservation). The actors involved may be varied involving individuals or groups (e.g. women; peasants; fishermen; indigenous; ethnic minorities; herders); organizations and networks (e.g. trans-nationals; national companies; governments; international organizations; non-governmental organizations; grassroots organizations) Each of these may act at different scales and hold different identities and power.

The political ecology literature accounts for certain common dynamics and shared characteristics of conflicts over access to resources, despite the wide-ranging array of possible conflicts resulting from combinations of different environmental resources with different activities and actors,.

Four analytical and conceptual pillars can be identified in the political ecology literature on resource access struggles.

Firstly, political ecology treats struggles over access to resources as struggles in defence of livelihoods that involve economic, ecological and cultural dimensions. These dimensions are intertwined in such a way that each one partly constitutes and is constituted by the others (Bryant, 1998; Escobar, 2006a; Li, 1996; Moore, 1993; Rocheleau and Ross, 1995).

The ecological dimension relates to the biophysical features of resources and environments and the environmental transformations affecting access to resources (Bryant and Bailey, 1997; Bryant, 1998; Watts and Peet, 2004; Peluso and Watts, 2001b: 5).

The economic dimension refers to the "unequal distribution of income and material resources" (Escobar, 2006a: 8).

The cultural dimension has to do with the "contrasting worldviews" of differentiated social actors regarding the interaction with nature (Escobar, 2006a).

Such "contrasting worldviews" are articulated in the languages of valuation representing the different, and often incommensurable, values that different actors attach to their relation with nature (Martinez-Alier, 2002). Thus, resource struggles are driven by economic distribution concerns, and they are also shaped by "local cultural categories for land and features of the environment" (Moore, 1993: 383).

Since the defence of livelihoods is at the centre of struggles for resource access, the multidimensional character of these struggles implies that livelihoods are also multi-dimensional. 
As Bebbington points out, "livelihoods are not only economically driven and structured, they are also imbued with cultural and political significance" (Bebbington, 2004: 177). Thus, livelihoods are not only a way of making a living (material dimension), but also a source of meaning and capabilities (Bebbington, 1999 and 2004; Bebbington et al., 2008a). In Bebbington's notion of livelihoods, the capabilities dimension is based on Amartya Sen concept of capabilities. Sen defines 'capability' as "the substantive freedom to achieve alternative functioning combinations". 'Functionings' are defined as "the various things a person may value doing or being" (Sen, 1999: 75). Thus, a set of capabilities represents "the freedoms people enjoy to choose between different ways of living that they can have reason to value" (Sen, 1990: 114).

Bebbington's multi-dimensional conception of livelihoods informs this dissertation. Likewise, the concept of valuation languages (or languages of valuation) - understood as the languages used by actors involved in socio-environmental conflicts to articulate their values, interests and concerns (Martinez-Alier, 2002 and 2009; Avc1 et al., 2010) - is used throughout this thesis as an analytical tool to explore the different dimensions of livelihoods that local actors defend (Chapter 5) and the different values of the actors involved in socioenvironmental conflicts (Chapter 6).

Secondly, political ecologists consider that these "conflicts are often conflicts of 'accumulation by dispossession' (Harvey, 2003) or 'accumulation through contamination' (Martinez-Alier, 2012: 349) in which the ability of the resisting actors to advance their own 'world views' in their relations with nature and to gain and control access is mediated by asymmetrical power relations (Bryant and Bailey, 1997; Martinez-Alier, 2002; Watts and Peet, 2004; Peluso and Watts, 2001b). The spectrum of the social actors involved is so wide that they do not necessarily fit analytical categories based on class or ethnic differentiation (Martinez-Alier, 2012).

Thus, political ecology accounts for the wide range of differentiated actors involved in conflict over access, "and the ways in which they operate in historically and culturally constituted fields of power" (Peluso and Watts, 2001b: 25).

Moreover, political ecology accounts for different processes underlying socioenvironmental conflicts: 'accumulation by dispossession'; 'accumulation through contamination'; and, 'assimilation'. It is accepted broadly in the field of political ecology that one of those processes is 'accumulation by dispossession' (Harvey, 2003). Harvey used the rubric of 'accumulation by dispossession' to refer to the continuation of all practices labelled by Marx as 'primitive accumulation'. He considered that these practices appear 
either in the same forms identified by Marx or in new guises (Harvey, 2003 and 2007). ${ }^{4}$ Thus, according to Harvey, 'accumulation by dispossession' is the processes of capital accumulation by certain human groups at the expense of the livelihoods of others.

Scholars working on socio-environmental conflicts connected with waste disposal and contamination have introduced the notion of 'accumulation by contamination' (Demaria, 2010).

Finally, Escobar (2006a and 2006b) uses the term 'assimilation' to refer to: practices of incorporation of local populations into modern processes of development, in an attempt to realise a measure of equity, that deny differences rooted in identity and culture. Many socio-environmental transformations in the name of development involve practices of 'assimilation' that are often contested by local populations. Thus, these 'assimilation' practices are connected with the cultural dimension of socio-environmental conflicts.

Thirdly, political ecology scholarship on socio-environmental conflicts considers that resistance encompasses a variety of strategies ranging from what Scott (1985) defined as 'everyday forms of peasant resistance' (see Section 2.2.2) to networked social mobilization across scales (Escobar, 2001). ${ }^{5}$ Resistance also encompasses the multiple languages of valuation used by local populations and social movements involved in socio-environmental conflicts to articulate their claims (Martinez-Alier, 2002).

Fourthly, political ecology studies have found that local struggles over access to resources are often linked to larger socio-economic and political processes and forces across time and scales (Blaikie and Brookfield, 1987; Bryant, and Bailey, 1997; Watts and Peet, 2004; Peluso and Watts, 2001b; Rocheleau et al., 1996). Therefore, contextual structural forces at different scales are relevant to explain:

\footnotetext{
${ }^{4}$ In Harvey's words 'accumulation by dispossession' practices include: "(1) the commodification and privatization of land and the forceful expulsion of peasant populations; (2) conversion of various forms of property rights (common, collective, state, etc.) into exclusively private property rights; (3) suppression of rights to the commons; (4) commodification of labor power and the suppression of alternative (indigenous) forms of production and consumption; (5) colonial, neocolonial, and imperial processes of appropriation of assets (including natural resources); (6) monetization of exchange and taxation, particularly of land; (7) the slave trade (which continues, particularly in the sex industry); and (8) usury, the national debt, and, most devastating of all, the use of the credit system as radical means of primitive accumulation" (Harvey, 2003 and 2007). This is only an indicative list as Harvey observes that since Marx's analysis "wholly new mechanisms of accumulation by dispossession have also opened up" (Harvey, 2003: 147-148).

${ }^{5}$ Within political ecology the notion of 'scale' is not related to physical size but to geographical space. See Section 2.2.1 for a more detailed explanation.
} 
i) who gains or maintains access to what and how, and

ii) the opportunities and constraints for social actors to exercise agency through different forms of resistance. ${ }^{6}$

These four points described above account for the conceptual and analytical pillars of the political ecology approach to socio-environmental conflicts and, particularly, struggles over access to resources that inform this dissertation.

An extensive body of theoretical and empirical studies builds upon these pillars including academic research published in refereed journal articles and books bringing together multiple case studies. ${ }^{7}$ It also encompasses empirical research conducted by, and with, nongovernmental organizations; grassroots organizations; and, advocacy groups. ${ }^{8}$ Indeed, "activist knowledge" is considered an important part of the field of political ecology (Bebbington, 2012c; Escobar, 2008; Robbins, 2012).

In Sections 2.2.1 to 2.2.4, I present a review of the political ecology literature on socioenvironmental conflicts. In view of the vast extent of this literature, the review is limited to the academic research on resource access struggles and conflicts connected with the expansion of commodity frontiers and, in particular, those connected with extraction frontiers, which include, not only mining, oil and gas extraction, but also agro-industrial activities (Bebbington, 2012b, Muradian et al., 2012, Svampa, 2011). ${ }^{9}$ Most of this literature dates from the last fifteen years. The reason is that political ecologists have turned

\footnotetext{
${ }^{6}$ In this thesis I follow the notion of agency adopted by Amartya Sen. Sen defines an agent "as someone who acts and brings about change, and whose achievements can be judged in terms of her own values and objectives" (Sen, 1999: 19).

${ }^{7}$ See for example the volumes edited by Paulson and Gezon, 2004; Peet and Watts, 1996a and 2004; Peluso and Watts, 2001a; Rocheleau et al., 1996, as well as the special sections in the journals Ecological Economics 70(2) and Global Environmental Change 22(3). A large number of refereed articles on case studies of socio-environmental conflicts can be found in journals such as The Journal of Political Ecology, Capitalism Nature Socialism, Geoforum, Development and Change, The Journal of Peasant Studies, Antipode, and Revista Ecología Política.

${ }^{8}$ Examples of this work are: i) the research on the black movement in the Colombian Pacific lead by Arturo Escobar (Escobar, 2008), and ii) the Ejolt project (Environmental Justice Organisations, Liabilities and Trade). Ejolt is an European Union funded project that brings together academics and activist working on the field of environmental justice across different countries (http://www.ejolt.org. Accessed November 5, 2013).

${ }^{9}$ Because this review focuses specifically on extractive frontiers, it includes neither studies on socioenvironmental conflicts connected with infrastructure projects, nor research on conflicts emerging from the so called 'green grabbing', i.e. "the appropriation of land and resources for environmental ends" such as those connected with nature conservation projects (Fairhead, et al., 2012). Therefore, for practical reasons, this review has a limited scope. It should not be interpreted as a neglect or denial of the commodities and commodification processes embodied in infrastructure projects such as the commodification of water in the case of the construction of dams to produce energy, and green grabbing which results in the commodification of land and nature.
} 
their attention to extractive activities mainly since the late 1990s and most of the writings have been published after 2000 (Bebbington, 2012c).

The review is divided into four broad topics that are important in a political ecology analysis of socio-environmental conflicts connected with the expansion of commodity frontiers:

1. Local-global and agency-structure interactions shaping resource access struggles in new commodity frontiers (Section 2.2.1)

2. Actors' power relations in resource access struggles (Section 2.2.2)

3. Socio-environmental conflicts and environmental justice (Section 2.2.3)

4. Socio-environmental conflicts and sustainability governance (Section 2.2.4).

2.2.1. Local-global and agency-structure interactions shaping resource access struggles in commodity frontiers

Political ecology scholarship emphasises the interconnectedness between local experiences of socio-environmental transformation and contestation, and global socio-economic and political processes (Biersack, 2006; Escobar, 2008; Paulson and Gezon, 2004; Rocheleau et al., 1996.).

These global-local and structure-agency interactions are the basis of any analysis of socioenvironmental conflicts connected with the expansion of commodity frontiers for two reasons.

First, expansion of commodity frontiers is a manifestation of global structural forces (expansion of world capitalism) transmitted into local places through markets and states (Moore, 2000; Peet and Watts, 1996b; Sikor, 2006).

Second, the socio-environmental consequences of such expansion in specific locales often lead to local resistance as an expression of agency in defence of local livelihoods (MartinezAlier; 2002). In many cases, local resistance resorts to 'glocal' strategies, such as the engagement in the politics of scale by:

i) establishing networks with organizations working at different scales that support local claims, and

ii) making coalitions with other place-based struggles (Escobar, 2001; Swyngedouw, 1997). 
The acknowledgement of global-local interactions in political ecology studies is grounded in a specific conception of scale. Generally speaking, in political ecology studies, 'scales' are understood as spatial scales (the global, the national, the regional, the local) in which boundaries are not fixed, but are constantly reconfigured. According to Swyngedouw, scales "are never fixed, but are perpetually redefined, contested, and restructured in terms of their extent, content, relative importance, and interrelations" (Swyngedouw, 1997: 141). "In the process, new significant social and ecological scales become constructed, others disappear or become transformed" (Swyngedouw, 2004, 132-3). Moreover, there is not a top-down hierarchy linking scales, as one scale contains elements of the other (Swyngedouw, 1997). This is the conception of scale that I use in this thesis.

I have identified three types of local-global and agency-structure interactions from the analysis in the recent literature on socio-environmental conflicts connected with the expansion of commodity frontiers, as follows:

1. Several studies emphasise the interactions between global structural forces shaping the expansion of commodity frontier and local or 'glocal' strategies of resistance as expression of agency (or the lack of them) (Conde and Kallis, 2012; Gerber, 2011; Gerber et al., 2009; Martinez-Alier, 2009; Martinez-Alier et al., 2010; Muradian et al., 2012; Orta-Martínez and Finer, 2010). They do so by linking socioenvironmental conflicts with the global growth of material flows and commodity markets. Such growth of flows and commodity markets is considered the ultimate driving force of place-based expansion of commodity frontiers threatening local livelihoods (Conde and Kallis, 2012; Gerber, 2011; Gerber et al., 2009; MartinezAlier, 2002 and 2009; Martinez-Alier et al., 2010; Muradian et al., 2012; OrtaMartínez and Finer, 2010; Stonich and Vandergeest, 2001; Bebbington, 2012a; Bebbington and Bury, 2013).

2. Various studies account for global-local interactions from the perspective of agency by focusing on the interests, values and politics of the actors involved in socioenvironmental conflicts. This research analyses the discursive articulation of different actors, the valuation languages they deploy and the interests and system of values these languages convey, the global, local and 'glocal' dimensions of the tactics and strategies of resistance, as well as those of resource appropriation or transformation, and the effects of these on livelihoods (Avc1 et al., 2010; Escobar, 2008; Muradian et al., 2003; Peña, D.G., 2003; Temper and Martinez-Alier, 2013; Watts, 2004; Walter and Martinez-Alier, 2010). A large portion of this research focuses on social movements, the conditions of their emergence (or lack of it), their organization, characteristics, the politics of resistance, and the outcomes of the social 
mobilisation in respect of the protection of livelihoods (Bebbington et al., 2008a; Escobar, 2008; Urkidi, 2010).

3. Many studies in the two sets of literature referred to above account for national/local geographies and structural factors mediating the emergence, dynamics and characteristics of the resistance and the conflicts (Conde and Kallis, 2012; Muradian et al., 2012; Orta-Martínez and Finer, 2010). However, most of them miss the third type of analysis of global-local and structure-agency interactions: the interactions between the global process of expansion of commodity frontiers and the factors at the national and local levels shaping country-specific trajectories of expansion (national geographies as well as national structural and relational forces).

This third type of interaction was analysed in detail in early landmark political ecology works about forest peoples' struggles for access to resources (Hecht and Cockburn, 1989; Peluso, 1992a and 1992b). They are addressed in a few of the more recent works on commodity frontiers and social mobilisation referred to above (Bebbington et al., 2008a; Conde and Kallis, 2012; Stonich and Vandergeest, 2001; Veuthey and Gerber, 2011). They appear prominently in the research on socioenvironmental conflicts connected with the expansion of extractive frontiers in Latin America published recently (Bebbington, 2012a; Bebbington and Bury, 2013).

The analysis of the interactions between the global process of expansion of commodity frontiers and the factors at the national and local levels shaping countryspecific trajectories of expansion is key to a political ecology analysis of socioenvironmental conflicts in commodity frontiers because these interactions define the context and fields of power in which access to resources is "defined, negotiated and contested" (Peet and Watts, 1996b: 9).

In Chapter 3, I focus specifically on the analysis of country-specific trajectories of expansion of commodity frontiers and the national political economies and geographies that mould them.

\subsubsection{Actors' power relations in resource access struggles}

Power is a key element in political ecology analyses of resource access struggles. The very concept of socio-environmental conflict is grounded in the idea of power differences between actors involved in a conflict. Although their theoretical grounds are different, both Foucault's and Gramsci's notions of power underlie much of the political ecology research on socio-environmental conflicts (Robbins, 2004). While Gramsci's thinking can be theoretically located in the tradition of Marxist structuralism, Foucault's thinking belongs to the tradition of post-structuralism. However, the fact that both notions of power inform the 
political ecology literature on socio-environmental conflicts is a reflection of the incorporation of agency-structure interactions in political ecology analyses.

Gramsci differentiates two forms of power: power based on domination (exercise of power as material force and coercion); and, power based on hegemony. By contrast with domination, hegemony refers to the exercise of power in the cultural and ideological realms through "the mobilisation of consent" (Olssen, 1999: 105). Thus, hegemony refers to power as intellectual and moral supremacy represented by consent, rather than by coercion (Gramsci, 1971: 57-58). The concept of power as hegemony informs much of the political ecology research on social mobilisation for resistance against the expansion of commodity frontiers. Such expansion is seen as a material manifestation of the neo-liberal and capitalist hegemonic ideas of development, while social movements that challenge the expansion are seen as carriers of counter-hegemonic alternatives that can trigger structural changes (Escobar, 2008; Bebbington, 2012c).

In the field of political ecology, social movements are understood mainly as "processes of collective action that are sustained across space and time, that reflect grievances around perceived injustices, and that constitute a pursuit of alternative agendas" (Bebbington et al., 2008a: 2892).

However, there are many local conflicts connected with the expansion of commodity frontiers involving forms of the 'environmentalism of the poor' that cannot be considered a social movement (Watts and Peet, 2004: 55). Many of those acts of resistance - in particular those that take place in rural areas - represent what Scott (1985) defines as peasant resistance, i.e. "any act(s) by member(s) of a subordinate class that is or are intended either to mitigate or deny claims ...made on that class by superordinate classes ... or to advance its own claims ... vis-à-vis those superordinate classes” (Scott, 1985: 290).

To a great extent, peasant resistance is expressed through what Scott (1985) calls 'everyday forms of peasant resistance' using 'weapons of the weak' such as 'footdragging, dissimulation, false-compliance, pilfering, feigned ignorance, slander, arson, sabotage, and so forth" (Scott, 1985: 29). In Scott's words 'everyday forms of peasant resistance' are "the prosaic but constant struggle between the peasantry and those who seek to extract labour, food, taxes, rents, and interest from them...They require little or no co-ordination or planning; they often represent a form of individual self-help; and they typically avoid any direct symbolic confrontation with authority or with elite norms" (Scott, 1985: 29). Scott explicitly refers to Gramsci's notion of hegemony as inadequate to define the type of power relations underlying 'everyday forms of peasant resistance' (Scott, 1985). However, peasant 
resistance to protect peasant livelihoods from the threats posed by the expansion of commodity frontiers rarely remains limited to everyday forms of resistance.

Peasant resistance, taking the form of 'environmentalism of the poor', regularly involves direct forms of confrontation (Guha, 2000), even if it does not transform into a social movement. Moreover, peasant resistance typically stands for counter-hegemonic forms of human-environment interaction, as opposed to hegemonic ideas of natural resource exploitation and development that underlie the expansion of commodity frontiers.

I engage with this counter-hegemonic understanding of peasant resistance against the expansion of commodity frontiers in Chapter 5. As the defence of livelihoods is at the centre of this type of peasant resistance, I adopt Bebbington's multi-dimensional conception of livelihoods, which allows reconciling Scott's notion of peasant resistance with Gramsci's understanding of power relations in terms of hegemony and counter-hegemony. If peasant livelihoods are defined, not only as a source of income and subsistence, but also as a source and expression of both identity and a specific way of being and living, peasant resistance to the expansion of commodity frontiers can be understood in counter-hegemonic terms.

The other notion of power that underpins political ecology research on resource access struggles is the concept of power developed by Foucault. Foucault did not develop a theory of power, rather he approached power in analytical terms, i.e. he was interested in analysing what power relations are about (Foucault, 1983). Thus, he conceptualised power as relational and positional. For him, the term power indicates relationships between individuals or groups defined by a mode of action destined "to structure the possible field of action of others" (Foucault, 1983: 221). In this conception, power relationships presuppose agency: "that 'the other' (the one over whom power is exercised) is thoroughly recognized and maintained to the very end as a person who acts; and that, faced with a relationship of power, a whole field of responses, reactions, results, and possible inventions may open up" (Foucault, 1983: 220). Thus, in Foucault's view, power "is not an institution, and not a structure; neither is it a certain strength we are endowed with; it is the name that one attributes to a complex strategical situation in a particular society" (Foucault, 1978: 93).

Political ecology literature on access to resources is strongly influenced by the Foucauldian notion of power, as "political ecologists have primarily understood this concept in relation to the ability of an actor to control their own interaction with the environment and the interaction of other actors with the environment" (Bryant and Bailey 1997: 37). Moreover, Foucault's conceptualisation of power is at the basis of the theory of access developed by Ribot and Peluso (Ribot and Peluso, 2003). This theory of access informs much of the recent political ecology research on resource access struggles, including this dissertation. 
Power is incorporated mainly in three different ways in the research on socio-environmental conflicts connected with the expansion of commodity frontiers.

First, most studies on socio-environmental conflicts that focus on social mobilisation analyse power relations in terms of the potential or actual ability of movements to: challenge the expansion of commodity frontiers and the socio-environmental effects they produce; and, influence institutional change (Bebbington et al., 2008a; Bebbington 2012a and 2012c; Conde and Kallis, 2012; Escobar, 2008; Urkidi, 2010).

Thus, these studies look at power in terms of the counter-hegemonic potential of social mobilisation.

Second, power relations are also approached by looking at the ways in which power manifests itself in terms of the ability to control one's and others' interactions with the environment through political, economic, discursive or coercive means. For example, some studies analyse power in terms of the ability to:

i) Advance claims through the mobilisation of knowledge and discourse (Buchanan, 2013), or

ii) Gain consensus by mobilising economic and political means (Orta-Martínez and Finer, 2010; Urkidi, 2010).

Other studies analyse how power manifests itself as the ability to impose decisions and decision-making procedures that privilege or exclude the points of view, values and valuation languages of some groups of actors involved in socio-environmental conflicts in relation with environmental resources, i.e. 'procedural power' (Martinez-Alier, 2002; Martinez-Alier et al., 2010; Muradian et al., 2003; Temper and Martinez-Alier, 2013; Walter and Martinez-Alier, 2010).

I use this notion of 'procedural power' in Chapter 6 for the analysis of power relations shaping participation in the national standard-setting processes of voluntary certification governance mechanisms.

Third, in some studies power is incorporated implicitly into the analysis, but it is not the specific subject of analysis. In such studies, power asymmetries are assumed on the basis of the position or certain attributes of the actors in terms of wealth, prestige, political, economic or social position. Thus, in this type of literature, it is considered that power is embodied by actors, such as the state; governmental agencies; transnational corporations; and, national or local elites. 
Only a few studies of socio-environmental conflicts in commodity frontiers engage with an analysis of the mechanisms that enable some of the actors involved in these conflicts to control access to resources for the expansion of frontiers (Bebbington et al., 2008a; Veuthey and Gerber, 2011). These mechanisms are the sources of power asymmetries underlying socio-environmental conflicts. In the case of expansion of commodity frontiers, these sources of power can be traced within governmental support. This happens because governments often stimulate the expansion of extractive activities in the name of development, so influencing who gains access to resources and how (Bebbington, 2012a, Svampa, 2011).

In Chapter 4, I analyse how governmental incentives to support extraction activities mediate power asymmetries between actors in access to resources. I do so on the basis of Ribot and Peluso's theory of access. Within this theory, access is placed in a political economic framework where structural and relational mechanisms to gain, maintain and control access to resources constitute strands of 'bundles of power' (Ribot and Peluso, 2003). Institutional incentives and stimuli to extractive industries may embody structural mechanisms of access to resources, such as capital, technology, as well as access to markets.

At the same time, the ability to benefit from state support by influencing policy-making and implementation depends on relational 'bundles of power', such as access to authority. Access analysis allows the unveiling of the mechanisms of access operating through governmental support to extractive activities. Therefore, it helps to shed lights on the political-economic forces and power relations underlying socio-environmental conflicts.

\subsubsection{Socio-environmental conflicts and environmental justice}

Although the environmental justice movement has its origins in the US, the 'environmentalism of the poor' embodied in mobilisation by local actors in defence of their livelihoods represents a struggle for environmental justice in the global South (MartinezAlier, 2002 and 2013).

Since its origins, political ecology has been engaged politically with contributing to environmental justice for marginalised, subaltern or relatively less powerful groups (Blaikie, 2012; Forsyth; 2008). ${ }^{10}$ However, environmental justice has not been conceptually problematized in most of the political ecology studies dealing with processes of socio-

\footnotetext{
${ }^{10}$ The concept of 'subaltern' has its origins in Gramsci's writing. Gramsci uses the term 'subaltern' to refer to individuals and human groups outside of hegemonic political, economic and social structures (Gramsci, 1971). The works of Boaventura de Sousa Santos, Arturo Escobar and Michael Burawoy, which inform this thesis, draw upon Gramsci's idea of subaltern. They use the term subaltern to refer to individuals and social groups that have been rendered invisible, silenced or marginalized by hegemonic structures of capitalism and colonialism, and by the hegemonic modern conception of development. This is the meaning of subaltern that I adopt in this thesis.
} 
environmental transformation and contestation by which injustices are produced and resisted. Environmental justice has remained as a normative backdrop and an underlying concept in such studies.

It is the environmental justice scholarship specifically focused on the analysis and theorisation of the scope and dimensions of the concept that has developed the conceptual foundations of environmental justice informing political ecology research (see, for example, Holifield et al., 2009; Low and Gleeson, 1998; Pulido, 1996; Schroeder et al., 2008; Schlosberg, 2004 and 2007; Walker and Bulkeley, 2006). Still, there is a natural crossfertilization and overlapping between the two lines of analysis (political ecology and environmental justice). For example, analyses of the politics of socio-environmental resistance have provided empirical and analytical grounding for more sophisticated conceptualizations of environmental justice than those exclusively rooted in the distributive justice paradigm (see for example Pulido, 1996; Schlosberg 2004 and 2007). ${ }^{11}$

One of those refined conceptualizations is Schlosberg's pluralistic and multidimensional notion of environmental justice (Schlosberg, 2004 and 2007) which incorporates notions of justice as distribution, recognition, participation and capabilities. Like the capabilities dimension in Bebbington's notion of livelihoods, the capabilities dimension in Schlosberg's conceptualisation of environmental justice is based on Sen's concept of capabilities. Schlosberg's notion is empirically grounded in a comprehensive examination of the conceptions and discourses of justice that environmental justice movements use to articulate their claims and concerns (Schlosberg, 2007). This notion has become the conceptual basis for much of the recent scholarship on environmental justice and socio-environmental conflicts (See, for example, Carruthers, 2008; Martin, 2013; Martinez-Alier, 2013; Urkidi and Walter, 2011; Walker and Bulkeley, 2006).

There is a substantial set of empirical studies based on the premise that socio-environmental conflicts are about contrasting, and often incommensurable, values expressed in valuation languages (Martinez-Alier, 2002 and 2009; Martinez-Alier et al., 2010). Much of these studies explore the plurality of value systems underlying the conflict through the analysis of the valuation languages deployed by the actors involved (Avc1 et al., 2010; Gerber, 2011; Muradian et al., 2003; Temper and Martinez-Alier, 2013; Urkidi, 2010; Veuthey and Gerber, 2011) These studies engage, implicitly or explicitly, with Schlosberg's notion of

\footnotetext{
11 The distributive justice paradigm refers to the conception of justice "defined solely as the distribution of goods in a society, and the best principles by which to distribute those goods" (Schlosberg, 2007: 3). For conceptualizations of environmental justice embracing the distributional notion of justice see for example Dobson, 1998; Low and Gleeson, 1998. Note that the literature about theories of justice the words distributive and distributional are used interchangeably.
} 
environmental justice as the valuation languages used to articulate resistance and contestation convey notions of distribution, participation, and recognition.

Only a few studies of socio-environmental conflicts connected with the expansion of commodity frontiers undertake a justice analysis focused on unveiling the dimensions of justice underlying the conflicts (Urkidi and Walter, 2011; Temper and Martinez-Alier, 2013). These studies analyse how environmental justice dimensions are articulated in the discourses of the actors resisting or opposing the expansion of commodity frontiers. This type of analysis has shed light on how articulation of different dimensions of justice across time and scales leads to different outcomes in terms of redressing the grievances elicited by the expansion of commodity frontiers.

However, analysis could be extended beyond the terrain of the discourses in order to unveil how different dimensions of justice are threatened in practice and defended through emancipatory politics in cases of local conflict and resistance connected with the expansion of commodity frontiers. I undertake this type of analysis in Chapter 5. I analyse the different dimensions of justice compromised when different dimensions of livelihoods are threatened and the emancipatory potential of the human rights politics of actors resisting the expansion of commodity frontiers. This analysis is based on Bebbington's multidimensional notion of livelihoods (Bebbington 1999 and 2004; Bebbington et al., 2008a), Schlosberg's conceptualization of environmental justice (Schlosberg, 2004 and 2007), and the multicultural conception of human rights developed by Boaventura de Sousa Santos. Under this notion, human rights, rather than being universal postulates, are just normative references for which the emancipatory potential depends on how they are articulated with local meanings (Santos, 2002 and 2007).

\subsubsection{Socio-environmental conflicts and sustainability governance}

The socio-environmental concerns at the core of socio-environmental conflicts are often addressed institutionally through state or private governance mechanisms and through processes of local consultation.

A characteristic of the contemporary expansion of commodity frontiers is that the socioenvironmental concerns they rise are tackled increasingly through non-state market-driven (NSMD) sustainability governance mechanisms, such as voluntary certification schemes aimed at ensuring producer compliance with a set of sustainability criteria. NSMD governance mechanisms are part of NSMD governance systems. NSMD governance systems are "deliberative and adaptive governance institutions designed to embed social and environmental norms in the global marketplace that derive authority directly from interested audiences, including those who seek to regulate, not from sovereign states" (Bernstein and Cashore, 2007: 348). 
Thus, a NSMD governance system encompasses the entire institutional apparatus underlying the adoption and implementation of a NSMD governance mechanism, which includes the NSMD governance mechanism itself. Typically, NSMD sustainability governance mechanisms have a global outreach. However, they are played out across scales. This is why the processes of adoption and implementation of NSMD sustainability governance mechanisms at the national scale are often arenas where resistance against expansion of commodity frontiers is reproduced in the form of contestation against one or more mechanisms of the governance system. This contestation challenges the very legitimacy of the governance system.

Some of the political ecology research related to how socio-environmental conflicts are institutionally handled focuses on analysing consultation processes (Muradian et al., 2003; Walter and Martinez-Alier, 2010). Other studies incorporate an analysis of how the concerns at the core of socio-environmental conflicts are handled by courts or other state institutions (Temper and Martinez-Alier, 2013).

There are only a few political ecology studies on NSMD sustainability governance mechanisms (Eden, 2004; Klooster, 2006). Moreover, most of them do not analyse contestation of these mechanisms at the national scale in connection with socioenvironmental conflicts. Only García-López and Arizpe's (2010) research on participatory processes in the soy conflicts in Paraguay and Argentina have engaged with this type of analysis.

Adoption and implementation of global NSMD sustainability governance mechanisms often require processes of sustainability criteria development at the national scale. Such national processes are arenas where 'procedural power' may be deployed in such a way that the plurality of values of actors involved in socio-environmental conflicts may be overlooked, so leading to legitimacy contestation of the NSMD governance system.

In Chapter 6, I incorporate political ecology concerns into the study of NSMD sustainability governance mechanisms by looking at how legitimacy granting or contestation from the part of local actors involved in socio-environmental conflicts is shaped by the way in which plurality of values and 'procedural power' are deployed in the national development of sustainability standards.

The study of legitimacy of non-state global governance systems has been traditionally approached using perspectives that come from the disciplines of law, political philosophy, political science and critical sociology (Bernstein, 2005; Schouten and Glasbergen, 2011). I 
adopt Bernstein's concept of legitimacy based on the critical sociology literature. Bernstein defines legitimacy as the acceptance of a rule by 'relevant audiences' as appropriate and justified (Bernstein, 2005 and 2011; Bernstein and Cashore, 2007).

In my analysis, I integrate Bernstein's concept of legitimacy with the concepts of valuation languages and 'procedural power' that meet at the intersections between the scholarship of political ecology and ecological economics.

\subsection{Epistemological underpinning}

This dissertation is guided epistemologically by the premises and procedures of the 'epistemologies of the South' (Santos, 2012) and the principles of the reflexive model of science (Burawoy, 1998a and 2009). The purpose of being explicit about the epistemological underpinning of this research is to make clear the scientific premises and principles on which this dissertation should be judged. As Burawoy puts it, "listen to the tune before evaluating the dance" (Burawoy, 2009: 69).

\subsubsection{Epistemologies of the South}

Boaventura de Sousa Santos defines the 'epistemologies of the South' as: "the retrieval of new processes of production and valorisation of valid knowledges, whether scientific or non- scientific, and of new relations among different types of knowledge on the basis of the practices of the classes and social groups that have suffered, in a systematic way, the oppression and discrimination caused by capitalism and colonialism" (Santos, 2012: 51). According to Santos, the South has to be understood not as a geographical category, but as "a metaphor of the human suffering caused by capitalism and colonialism at the global level, and a metaphor as well of the resistance to overcome or minimise such suffering" (Santos, 2012: 51). Therefore, the South also exists in the Global North, and "there is also a Global North in countries of the South, consisting of the local elites that take advantage of the production and reproduction of capitalism and colonialism" (Santos, 2012: 63).

The 'epistemologies of the South' are based on the premise that concepts and theories of modern Western science do not adequately identify or value the different forms of being, thinking, feeling and organising life and production of the subaltern groups of the South, as well as their different ways of conceiving of the relations among human beings and between humans and not-humans (Santos, 2006 and 2012). ${ }^{12}$

\footnotetext{
${ }^{12}$ As the 'epistemologies of South' may inform research on a multiplicity of topics (not only political ecology studies), Santos uses the term 'non-humans' not only to refer to elements of nature (plants, animals, land, mountains, rivers, the sun, etc...), but also cultural and spiritual entities (for example, gods, devils or objects that carry traditional meanings).
} 
Thus, the 'epistemologies of the South' refer to "an alternative thinking of alternatives" (Santos, 2012: 52) by practicing what Santos calls the 'sociology of the absences' and the 'sociology of emergences' (Santos, 2006 and 2012). The 'sociology of the absences' involves both researching and making visible the experiences and ways of living and being that dominant worldviews attempt to render invisible or absent, and unveiling how the absences are produced. The 'sociology of emergences' "entails interpreting in an expansive way the initiatives, movements and organizations [that emerge] to resist neoliberal globalisation and offer alternatives to it. The traits of the struggles are amplified so as to render visible and credible the potential that lies implicit or remains embryonic in the experiences under examination" (Santos and Rodríguez-Garavito, 2005: 17).

A political ecology that accounts for the analytical relevance of difference (Escobar, 2006a and 2008) is epistemologically aligned with the premises and procedures of the 'epistemologies of the South'. It does so by making visible the difference of subaltern groups in their relations with the environment, unveiling how the difference is denied, and placing emphasis on the emancipatory potential of the forms of resistance that emerge against such denial. This is the political ecology that provides the conceptual and theoretical basis of this dissertation.

\subsubsection{The reflexive model of science}

The reflexive model of science is an epistemological approach to social science research proposed by Burawoy (1998a and 2009) based on two premises:

1. The context in which the researched situation is embedded is in a position of mutual determination with the situation itself, and

2. the positionality of the researcher has consequences for the results and the analysis. By 'positionality' Burawoy means:

i) the researcher's "embodiment and biography" (race, gender, age, origins, education as well as the social and intellectual position vis-à-vis the participants, informants and the situation studied), and

ii) the standpoint from which the researcher approaches the research (Burawoy, 2009: 204). ${ }^{13}$

In contrast with positive science that embraces detachment of the researcher from the researched, reflexive science is guided by inter-subjectivity and real or virtual dialogue

\footnotetext{
${ }^{13}$ The term 'participants' refer to the actors involved in the situation researched.
} 
between the researcher and the actors involved in the situation researched (i.e. the participants). Thus, the reflexive science "takes context as its point of departure, [and] thematizes our presence in the world we study" (Burawoy, 2009: 25).

Moreover, objectivity and neutrality, as understood by positivist science, are not possible in the research that is epistemologically grounded in a reflexive model of science. In reflexive science "objectivity is not measured by procedures that assure an accurate mapping of the world, but by the growth of knowledge" through theory development and reconstruction (Burawoy, 2009: 21). Reconstruction "that leaves core postulates intact, that does as well as the pre-existing theory upon which they are built, and that absorbs anomalies with parsimony, offering novel angles of vision". The "theoretical point of departure can range from the folk theory of participants to any abstract law. We require only that the scientist considers it worth developing" (Burawoy, 2009: 43).

The reflexive model of science arose from a critical engagement with the principles of positive science: no-reactivity (detachment of the researcher from the researched), reliability, replicability and representativeness (Burawoy, 1998: 11). As the compliance with the principles of positive science is challenged by the existence of context effects, the principles of the reflexive model of science "spring from the irrevocable gap between positive science and its practice" (Burawoy, 2009: 35). However, power effects in the practice of reflexive science constitute its limits. The practice of reflexive science requires the exercise of reflexivity - "the self-monitoring of behaviour" (Burawoy, 1998: 13) - in order to display "the effects of power so that they can be better understood and contained" (Burawoy, 2009: 61).

Table 2.1 shows the principles of both positive and reflexive models of science and the challenges they face in the practice of social science research. These challenges are posed by context effects in the case of positive science, and power effects in the case of reflexive science.

In this dissertation, I engage with the reflexive model of science by applying the 'extended case method' to the case study research. Following the principles of reflexive science, the 'extended case method' is based on the idea that there is a world outside ourselves that researchers can know only through their relation to it, and the research is part of that world (Burawoy, 2009: 123; see also Section 2.4.1 below). I apply the 'extend case method' to the study of the expansion of the palm oil frontier in Colombia between 2000 and 2010 and the contestation and conflicts connected with such expansion. 
Table 2.1. Principles of positive and reflexive models of science, and context and power effects in the research practice

\begin{tabular}{|c|c|c|c|}
\hline \multicolumn{2}{|c|}{ Positive Science } & \multicolumn{2}{|c|}{ Reflexive Science } \\
\hline Principles Of Positive Science & $\begin{array}{l}\text { Context Effects In The Practice Of } \\
\text { Research That Challenge The } \\
\text { Realisation Of Positive Principles }\end{array}$ & Principles Of Reflexive Science & $\begin{array}{l}\text { Power Effects In The Practice Of } \\
\text { Reflexive Research }\end{array}$ \\
\hline $\begin{array}{l}\text { No-Reactivity: } \\
\text { Avoiding affecting the worlds studied }\end{array}$ & $\begin{array}{l}\text { Interview effects: } \\
\text { Researcher's characteristics and } \\
\text { position, as well as interview schedule } \\
\text { and the context conditions of time and } \\
\text { space at the time of the interview, affect } \\
\text { responses. }\end{array}$ & $\begin{array}{l}\text { Intervention: } \\
\text { Intervening in the social situation } \\
\text { investigated by establishing an inter- } \\
\text { subjective dialogue with the } \\
\text { participants. Moving really or virtually } \\
\text { with participants through their space } \\
\text { and time }\end{array}$ & $\begin{array}{l}\text { Domination: } \\
\text { Intervention entails entering into power } \\
\text { relations. Along the research process } \\
\text { the researcher is sometimes being } \\
\text { dominated and sometimes it dominates. } \\
\text { This influences the research process and } \\
\text { its outcomes }\end{array}$ \\
\hline $\begin{array}{l}\text { Reliability: } \\
\text { Pre-defined set of criteria informing } \\
\text { data collection }\end{array}$ & $\begin{array}{l}\text { Respondent effects: } \\
\text { The influence of respondents' world or } \\
\text { everyday life in the meaning they } \\
\text { attribute to questions (respondent's } \\
\text { world or everyday life does not } \\
\text { necessarily fit in a predefined template). }\end{array}$ & $\begin{array}{l}\text { Process: } \\
\text { Aggregation of situational knowledge } \\
\text { into social process. }\end{array}$ & $\begin{array}{l}\text { Silencing: } \\
\text { The process of aggregation situational } \\
\text { knowledge into social process, } \\
\text { inevitable leads to silencing and } \\
\text { marginalizing some voices while other } \\
\text { are disclosed and prioritised. }\end{array}$ \\
\hline $\begin{array}{l}\text { Replicability: } \\
\text { The codes of data collection and } \\
\text { analysis should be formulated } \\
\text { unambiguously so that results can be } \\
\text { reproduced by other researchers } \\
\text { studying the same phenomenon. }\end{array}$ & $\begin{array}{l}\text { Field effects: } \\
\text { Political, social, and economic contexts } \\
\text { at the time and place of interviews } \\
\text { influence interviewees' responses. }\end{array}$ & $\begin{array}{l}\text { Structuration: } \\
\text { Connecting social processes with } \\
\text { external social forces in a relation of } \\
\text { mutual determination. }\end{array}$ & $\begin{array}{l}\text { Objectification: } \\
\text { Over-representing social forces as } \\
\text { systemic and external. }\end{array}$ \\
\hline $\begin{array}{l}\text { Representativeness: } \\
\text { "Guaranteeing that the slice of the } \\
\text { world under analysis is typical of the } \\
\text { whole" to aid development of theory. } \\
\text { (Representativeness is thus the principle } \\
\text { guiding case selection). }\end{array}$ & $\begin{array}{l}\text { Situation effects: } \\
\text { The meanings, attitudes and knowledge } \\
\text { constituted in the social situation under } \\
\text { investigation are specific to that } \\
\text { situation. }\end{array}$ & $\begin{array}{l}\text { Reconstruction: } \\
\text { Using the specificities of the case for } \\
\text { the development and elaboration of } \\
\text { theory }\end{array}$ & $\begin{array}{l}\text { Normalization: } \\
\text { Under the reflexive model of science } \\
\text { representativeness does not guide case } \\
\text { selection. However, in the process of } \\
\text { elaborating on the theory and concepts } \\
\text { that guided the research, complex } \\
\text { situations are reduced to "categories } \\
\text { that can be investigated", and the field } \\
\text { site is reduced to the case or cases } \\
\text { studied. }\end{array}$ \\
\hline
\end{tabular}

Source: Burawoy, 1998a and 2009. 


\subsection{Research design and methodology}

In the literature review presented in Section 2.2, I outlined four aspects of the political ecology of socio-environmental conflicts connected with the expansion of commodity frontiers that are addressed in this dissertation. These four aspects are articulated in the following research sub-questions that develop the overarching research question of this thesis.

\section{Overarching Research Question:}

How is the expansion of commodity frontiers manifested in country-specific trajectories of inequitable resource access?

Research Sub-question 1 (R-SQ 1): How does the global expansion of commodity frontiers interact with national geographies and socioeconomic and political processes to produce country-specific trajectories of expansion and resource access control? (Chapter 3 ).

Research Sub-question 2 (R-SQ 2): How do governmental incentives to support extraction activities mediate power asymmetries among actors in access to resources? (Chapter 4).

Research Sub-question 3 (R-SQ 3): How are the dimensions of justice threatened in practice and defended through the politics of human rights in cases of local resistance connected with the expansion of commodity frontiers? (Chapter 5).

Research Sub-question 4 (R-SQ 4): How do power asymmetries among local actors and differences in values deployed in national standard-setting processes influence legitimacy contestation of NSMD sustainability governance systems at the national scale? (Chapter 6).

I address these questions through a qualitative case study of the expansion of the palm oil frontier in Colombia between 2000 and 2010 and the resource access struggles and contestation connected with such an expansion, applying the 'extended case method' developed by Michael Burawoy (1998 and 2009).

\subsubsection{Case study research and the 'extended case method'}

As pointed out in the introduction of this chapter, methodological choices are informed and should be consistent with epistemological orientations. Thus, the choice for the 'extended case method' is justified in the epistemological underpinning of this thesis, i.e. the reflexive model of science and the 'epistemologies of the South'. 
The 'extended case method' consists in the application of the principles of reflexive science to case study research "in order to extract the general from the unique, to move from the 'micro' to the 'macro', to connect the present to the past in anticipation of the future, all by building on preexisting theory" (Burawoy, 2009: 21).

The uniqueness of the case is not a problem because, true to the principles of reflexive science, the interest in the case is grounded in its contribution to developing theory through the responses to the research questions, rather than in its representativeness (Burawoy, 2009: 43). A case study using the 'extended case method' is not replicable according to the norms of positive science due to context effects. Thus, the study can be repeated, not as a replication, but as an extension of the former study that may offer new insights into the situation studied (Burawoy, 2009: 34).

The 'extended case method' also brings into practice one of the foundations of the 'epistemologies of the South': the 'sociology of the emergences'. Through the 'extended case method', the researcher "concentrates on digging up the subaltern" (Burawoy, 2009: 265) looking for alternative institutions and experiments that have emancipatory potential. In doing so, her research both looks upon the situations in the field "as the foundation of an alternative order" and "keeps alive the ideals of social and political justice that are in danger of being lost or neutered in capitalist accumulation" (Burawoy, 2009: 265).

Following the principles of the reflexive science - intervention, process, structuration and reconstruction - the 'extended case method' consists of four elements that Burawoy calls 'extensions':

1. Interacting with the researched situation and with the participants (extension of the researcher into the situation and the lives of the participants). This interaction means "moving with the actors involved in the situation studied through their space and time" in order "to unpack their situational experiences" (Burawoy, 1998:14). This implies intervention in the form of a dialogue between the researcher and the participants. Such dialogue is informed by academic theory in the case of the researcher, and the narratives of the actors involved in the situation researched. By contrast with positivist principles, this interaction is influenced by the researcher's positionality, i.e. who the researcher is (the researcher's background and social and intellectual position vis-à-vis the participants and informants) and the standpoint from which the researcher approaches the research. The interaction can be real or virtual depending on the technique used. For example, interaction is virtual in the case of historical interpretation. Ethnographic participant observation is the technique that provides the closest interaction in real terms. Other techniques, such 
as interviews and group meetings, can be deployed in accordance with the principles of reflexive science when "the interviewer proceeds through dialogue", i.e. "the interviewer allows respondents to tell their own story, to offer their own narrative". (Burawoy, 2009: 37). In this way, these techniques are rendered inter-subjective, highlight process through space and time, and locate the respondents "in historical and social milieus. Each of the three forgoing elements is embedded in the reconstitution of theory" (Burawoy, 1998b: 16). So deployed, interviews and group meetings represent a combination of real and virtual interaction.

2. Compiling the situational knowledge that emerges from the interaction with the situation studied into an account of social processes. In so doing, the researcher should account for the power relations "that structure situations into social processes" (Burawoy, 1998: 18). This element of the 'extended case method' is what Burawoy calls the extension from voices and observations in social situations to processes.

3. "Locating social processes at the site of research in a relation of mutual determination with an external field of social forces" (Burawoy, 1998: 18). This corresponds with the principle of structuration under which the situation researched in the field site is regarded "as simultaneously shaped by and shaping an external field of forces" (Burawoy, 1998: 15). This element of the 'extended case method' is what Burawoy calls the extension from processes to forces.

4. Developing the theoretical and conceptual background that informed the research (the extension of theory).

The entire research process using the 'extended case method' is guided by theory and the exercise of reflexivity. "Theory guides interventions, it constitutes situated knowledges into social processes, and it locates those social processes in their wider context of determination" (Burawoy, 2009: 55). Moreover, the findings that do not fit with the theoretical premises informing the research are "not cause for theoretical rejection but an opportunity for theoretical expansion" and "theory becomes an intervention into the world it seeks to comprehend" (Burawoy, 2009: 55).

Reflexivity helps us to be alert about and to try to minimise the effects that the positionality of the researcher and the inter-subjectivity involved in the field intervention have in the research process and its outcomes.

Table 2.2 shows how the 'extended case method' was applied in the construction of the case presented in this dissertation. 
Table 2.2. Application of the 'extended case method' to the case study on resource access struggles and the 2000-2010 expansion of the palm oil frontier in Colombia

\begin{tabular}{|c|c|c|c|}
\hline $\begin{array}{c}\text { Reflexive Science Principles } \\
\text { Applied Through The 'Extended } \\
\text { Case Method' }\end{array}$ & $\begin{array}{l}\text { Construction Of The Case Of This } \\
\text { Dissertation Using The 'Extend Case } \\
\text { Method' }\end{array}$ & $\begin{array}{l}\text { Research } \\
\text { Questions }\end{array}$ & Theoretical And Conceptual Underpinning \\
\hline $\begin{array}{l}\text { Intervention } \\
\text { Unpacking situational experiences of } \\
\text { the case by interacting virtually } \\
\text { and/or really with the situation and } \\
\text { participants across time and space }\end{array}$ & $\begin{array}{l}\text { Research on local conflicts and forms of } \\
\text { resistance and contestation connected with the } \\
\text { expansion of the palm oil frontier in Colombia, } \\
\text { based on fieldwork research (real intervention) } \\
\text { and extensive review of secondary data sources } \\
\text { (virtual intervention). }\end{array}$ & $\begin{array}{l}\text { S-RQ. } 1 \text { (Chapter 3) } \\
\text { S-RQ. } 3 \text { (Chapter 5) } \\
\text { S-RQ. } 4 \text { (Chapter 6) }\end{array}$ & $\begin{array}{l}\text { Political ecology } \\
\text { Ecological economics (languages of valuation, } \\
\text { commodity metabolism) } \\
\text { Environmental justice } \\
\text { Human rights } \\
\text { Critical Sociology on non-state market-driven } \\
\text { governance } \\
\text { Peasant studies }\end{array}$ \\
\hline $\begin{array}{l}\text { Process } \\
\text { Compiling situational knowledge in } \\
\text { social processes taking into account } \\
\text { power relations }\end{array}$ & $\begin{array}{l}\text { Compilation of local conflicts and forms of } \\
\text { contestation into an account of social processes } \\
\text { of resource access control and resistance } \\
\text { connected with the expansion of the palm oil } \\
\text { frontier in Colombia. }\end{array}$ & $\begin{array}{l}\text { S-RQ. } 1 \text { (Chapter 3) } \\
\text { S-RQ. } 4 \text { (Chapter 6) }\end{array}$ & $\begin{array}{l}\text { Political ecology } \\
\text { Ecological economics (languages of valuation) } \\
\text { Political economy } \\
\text { Peasant studies }\end{array}$ \\
\hline $\begin{array}{l}\text { Structuration } \\
\text { Locating social processes at the site } \\
\text { of research in a relation of mutual } \\
\text { determination with an external field } \\
\text { of social forces }\end{array}$ & $\begin{array}{l}\text { Establishing the interrelations between country- } \\
\text { specific trajectories of expansion and } \\
\text { contestation of the palm oil frontier in } \\
\text { Colombia, and socio-economic and political } \\
\text { forces shaping such trajectories. }\end{array}$ & $\begin{array}{l}\text { S-RQ. } 1 \text { (Chapter 3) } \\
\text { S-RQ. } 2 \text { (Chapter 4) } \\
\text { S-RQ. } 4 \text { (Chapter 6) }\end{array}$ & $\begin{array}{l}\text { Political ecology and Ecological economics } \\
\text { Political economy } \\
\text { Critical Sociology on non-state market-driven } \\
\text { governance } \\
\text { Peasant studies }\end{array}$ \\
\hline $\begin{array}{l}\text { Reconstruction } \\
\text { Elaborating and improving the } \\
\text { theoretical and conceptual } \\
\text { background }\end{array}$ & $\begin{array}{l}\text { Expanding knowledge on socio-environmental } \\
\text { conflicts and resistance connected with the } \\
\text { expansion of commodity frontiers }\end{array}$ & $\begin{array}{l}\text { Overarching research } \\
\text { question } \\
\text { (Chapter 7) }\end{array}$ & Political ecology \\
\hline
\end{tabular}


The case presented in this dissertation is based on a combination of real and virtual interventions: fieldwork and an extensive review of secondary sources. Fieldwork was carried out in Colombia during two periods. The first fieldwork (January-February of 2010) was exploratory. It resulted in 22 in-depth interviews and one group meeting in two different regions of oil palm cultivation (Central and East Regions); and, one institutional workshop in Bogotá - capital of Colombia.

The institutional workshop involved the participation of members of civil society organizations, academia, practitioners and business actors connected with the palm oil agroindustry.

This exploratory fieldwork was aimed at:

i) Gathering information on the situation of the palm oil expansion in Colombia in order to refine the research questions and the theoretical and conceptual background, and

ii) Establishing the practical conditions to conduct further fieldwork on local cases of conflict and contestation connected with the expansion of the palm oil frontier in different locations of the national palm oil geography.

The practical conditions refer to possibilities and constraints to enter into field sites and approach the relevant actors. Establishing these practical conditions was particularly relevant for this research. This is because the locations of oil palm cultivation in Colombia are areas hardly affected by the national armed conflict, and some of them are strongly affected by floods during the rainy season.

Security conditions, climatic conditions, and the support of local organization or individuals willing to introduce the researcher into the field site are important factors that enable or constrain the practicability of fieldwork in Colombia. Therefore, the selection of the sites and time of the year to conduct the second fieldwork, as well as the choice of the local cases studied, were highly influenced by the practical conditions identified during the exploratory fieldwork.

The second fieldwork was conducted between August and December of 2011. During this period, 24 in-depth interviews and four group meetings with different actors and key informants were held as detailed in Appendix A - Table A.2. 
As the case study focuses on the country-specific trajectories of expansion of the palm oil frontier in Colombia and the contestation and conflicts connected with such expansion, the second fieldwork involved:

i) Collecting data about the trajectories of expansion of the palm oil frontier at the national level through interviews with key informants, as well as my participation in forums and meetings relevant for the research. ${ }^{14}$ Since most of the key informants and forums that could provide data about the expansion at the national level were in Bogotá, a substantial part of the fieldwork was carried out there.

ii) Intervention in one region of oil palm cultivation (the Central Region of the palm oil geography), specifically in three cases of conflict and resistance connected with the expansion of the palm oil frontier.

Oil palm cultivation and palm oil production in Colombia are organised in four geographical regions (North, East, Central and South-west) that constitute the geography of the palm oil frontier. This geography is mainly determined by the edapho-climatic conditions - i.e. specific soil qualities, altitude, topography, temperature, humidity, precipitation, solar radiation and hydric balance - required for oil palm cultivation. Although the 2000-2010 expansion of the frontier took place within these regional limits, the vastness of the regions allowed the large expansion in hectares. The amount of land cultivated with oil palm almost tripled from 157,000 hectares in 2000 to 404,000 hectares in 2010 (Fedepalma, 2005 and 2011a).

Such expansion took place, not only in the municipalities where oil palm had been traditionally grown until the end of the 1990s, but also across new municipalities, so shaping and expanding the new frontier. The number of municipalities with oil palm plantations more than doubled during the 2000-2010 period from 47 in 1999 to 106 in 2010.

A map of the four regions of oil palm cultivation that shows how the frontier extended across municipalities between 2000 and 2010 is presented in Chapter 3 (Map 3.1).

Within the vast palm oil geography I chose to do the focalised fieldwork in the Central Region of the palm oil geography, specifically about three cases of conflict and resistance. The Central Region of the palm oil geography includes municipalities located within, or in the border with, the sub-regions of Catatumbo and Magdalena Medio of the national geography. The three cases come specifically from the Magdalena Medio sub-region

\footnotetext{
${ }^{14}$ Key informants are interviewees who provide the researcher "with insights into a matter but also can suggest sources of corroboratory or contrary evidence-and also initiate the access to such sources" (Yin, 2009: 107).
} 
(Municipalities of San Alberto and Sabana de Torres) and a neighbouring locality (Municipality of El Peñón).

Chapter 5 presents the details of the expansion of the palm oil frontier in the Central Region and the three cases studied, including a map of the Central Region showing the Magdalena Medio sub-region and the specific municipalities where the cases are located. The choice for the Central Region, and, in particular, the choice for cases located in the Magdalena Medio sub-region, was influenced by the exploratory fieldwork (first period of fieldwork).

During the exploratory fieldwork it became clear to me that in all the four regions of oil palm cultivation:

i) there were security risks as the cultivation of oil palm takes place in rural localities where the internal armed conflict has been fought over and have been high rates of internal displacement operated by illegal armed actors (see Chapter 3),

ii) collecting data on specific cases of conflict and resistance in connection with the expansion of oil cultivation and entering into contact with the local populations involved in those cases required being introduced into the field sites by nongovernmental or grassroots organizations working locally.

Entering into the field sites through these organizations would also lower the security risks as they have a lot knowledge of when, how, where and with whom it is safe to do fieldwork. During the exploratory fieldwork I found that I would have more possibilities to enter into field sites and approach the relevant actors in the Central Region of the palm oil geography than in the other three regions of the palm oil geography. The reason was that in the Central Region of the palm oil geography, and, specifically in the Magdalena Medio sub-region, a couple of non-governmental organizations working on the effects of the expansion of the palm oil frontier were willing to introduce me into the field sites and establish contact with local populations involved in cases of conflict with oil palm companies.

The application of the 'extended case method' to the case study in Colombia took the form of an iterative process. In this process, fieldwork and virtual interventions were based on initial research questions and assumptions informed by political ecology literature. The initial questions and assumptions were reformulated on the basis of the results of interventions.

The analysis in the form of process and structuration resulted from the reformulation of the initial questions and assumptions. Such analysis, as well as the further reconstruction of theory entailed, not only the application of political ecology theories, concepts and 
analytical tools, but also the incorporation of concepts and theories from other fields: ecological economics; political economy; peasant studies; environmental justice; human rights; and, critical sociology.

Writing the results of this iterative process in the form of this dissertation entailed a process of crafting research questions and analysis to produce of a coherent and fluid narrative. The resulting assemblage is presented in Table 2.3. This contains the research questions and summarises the conceptual toolkits, analytical strategies and data collection techniques used in the case study research. Each of the chapters addressing the research questions contains a more detailed account of the analytical and conceptual framework applied in that specific chapter.

\subsubsection{Caveats}

\subsubsection{Where is the ecology?}

Political ecology has been criticised because of the lack of engagement with the analysis of biophysical ecological change in much of the studies that claim to follow a political ecology approach (Walker, 2005; Vayda and Walters, 1999). This criticism has been addressed already in some of the literature that present an account of political ecology studies with a strong component of ecology (Walker, 2005; Watts and Peet, 2004). Moreover, political ecologists have pointed out that the ecology is addressed by approaching the environment in multiple ways, as "political ecology rests on the dialectics of Nature and Society" (Watts and Peet, 2004: 17; Bryant and Bailey, 1997).

In this thesis I embrace the following definition of environment: "environments are combined socioecological assemblages that are dynamically produced, spatially and temporally, socially and materially" (Swyngedouw and Heynen, 2003: 912; Escobar 2001). According to this definition, environments are made of both physical spaces and social relations. This academic conceptualisation of environments resembles the notion of territory used by some local populations to refer to the "multidimensional space for the creation and recreation of the ecological, economic, and cultural practices of the communities" (Escobar, 2001: 162; Martinez-Alier et al., 2014). Thus, the territory is made of physical spaces and social relations as it encompasses the cultural, ecological and productive dimensions of local population's lives (Escobar, 2001 and 2008).

In this dissertation, I use both terms - environments and territories - interchangeably to refer to the spaces that sustain the local populations' livelihoods threatened by the expansion of commodity frontiers. 
Table 2.3. Research design

\begin{tabular}{|c|c|c|c|c|c|c|}
\hline & Research Questions & Case Study & Conceptual Toolkit & $\begin{array}{c}\text { Analytical } \\
\text { Strategy }\end{array}$ & Data Collection Techniques \\
\hline \multirow{4}{*}{ 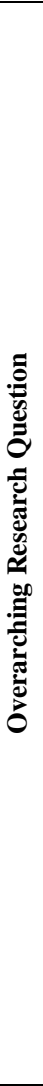 } & \multirow{4}{*}{ 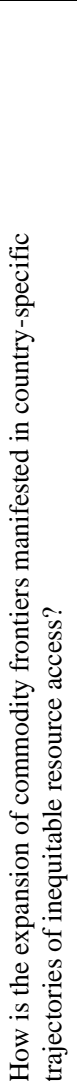 } & $\begin{array}{l}\text { How does the global expansion } \\
\text { of commodity frontiers interact } \\
\text { with national geographies and } \\
\text { socioeconomic and political } \\
\text { processes to produce country- } \\
\text { specific trajectories of expansion } \\
\text { and resource access control? } \\
\text { (Chapter 3). }\end{array}$ & $\begin{array}{l}\text { Analysis of the country- } \\
\text { specific trajectories of } \\
\text { expansion of the palm oil } \\
\text { frontier in Colombia and } \\
\text { the practices of land } \\
\text { control and resistance. }\end{array}$ & $\begin{array}{l}\text { - Commodity frontiers } \\
\text { - Accumulation by } \\
\text { dispossession } \\
\text { - Assimilation } \\
\text { - Land control } \\
\text { - Socio-environmental conflicts } \\
\text { - Flex crops }\end{array}$ & $\begin{array}{l}\text { Analysis of the } \\
\text { commodity } \\
\text { metabolism }\end{array}$ & $\begin{array}{l}\text { Review of secondary sources } \\
\text { documenting the expansion of } \\
\text { the palm oil frontier in } \\
\text { Colombia. } \\
\text { - Compilation of cases of } \\
\text { accumulation by dispossession } \\
\text { and socio-environmental } \\
\text { conflicts based on literature } \\
\text { review and fieldwork interviews. }\end{array}$ \\
\hline & & $\begin{array}{l}\text { How do governmental } \\
\text { incentives to support extraction } \\
\text { activities mediate power } \\
\text { asymmetries among actors in } \\
\text { access to resources? (Chapter 4). }\end{array}$ & $\begin{array}{l}\text { Analysis of how } \\
\text { governmental support to } \\
\text { the palm oil agro-industry } \\
\text { in Colombia mediates } \\
\text { power asymmetries in } \\
\text { access to land. }\end{array}$ & $\begin{array}{l}\text { - Access } \\
\text { - Power }\end{array}$ & Access analysis & $\begin{array}{l}\text { Review of secondary sources } \\
\text { documenting the expansion of } \\
\text { the palm oil frontier in Colombia } \\
\text { and the governmental support to } \\
\text { the palm oil agro-industry. } \\
\text { - Fieldwork interviews with key } \\
\text { informants. }\end{array}$ \\
\hline & & $\begin{array}{l}\text { How are the dimensions of } \\
\text { justice threatened in practice and } \\
\text { defended through the politics of } \\
\text { human rights in cases of local } \\
\text { resistance connected with the } \\
\text { expansion of commodity } \\
\text { frontiers? (Chapter 5) }\end{array}$ & $\begin{array}{l}\text { Analysis of cases of } \\
\text { conflicts resulting from } \\
\text { peasant resistance to } \\
\text { defend their livelihoods } \\
\text { from the threats posed by } \\
\text { expansion of the palm oil } \\
\text { frontier. }\end{array}$ & $\begin{array}{l}\text { - Socio-environmental conflicts } \\
\text { - Livelihoods } \\
\text { - Accumulation by } \\
\text { dispossession } \\
\text { - Assimilation } \\
\text { - Valuation languages } \\
\text { - Environmental justice } \\
\text { - Multicultural Human rights } \\
\end{array}$ & Justice analysis & $\begin{array}{l}\text { Fieldwork interviews with actors } \\
\text { involved in the cases and key } \\
\text { informants. } \\
\text { - Participant observation during } \\
\text { field visits to the local sites. } \\
\text { - Review of secondary sources } \\
\text { documenting the cases. }\end{array}$ \\
\hline & & $\begin{array}{l}\text { How do power asymmetries } \\
\text { among local actors and } \\
\text { differences in values deployed } \\
\text { in national standard-setting } \\
\text { processes influence legitimacy } \\
\text { contestation of NSMD } \\
\text { sustainability governance } \\
\text { systems at the national scale? } \\
\text { (Chapter 6). }\end{array}$ & $\begin{array}{l}\text { Analysis of legitimacy } \\
\text { contestation of the RSPO } \\
\text { in Colombia. }\end{array}$ & $\begin{array}{l}\text { - NSMD governance systems } \\
\text { - Legitimacy } \\
\text { - Procedural power } \\
\text { - Valuation languages } \\
\text { - Socio-environmental conflicts }\end{array}$ & $\begin{array}{l}\text { Substantive and } \\
\text { procedural } \\
\text { analysis of NSMD } \\
\text { governance } \\
\text { systems } \\
\text { legitimacy. }\end{array}$ & $\begin{array}{l}\text { Review of secondary sources } \\
\text { documenting the process of } \\
\text { national interpretation of the } \\
\text { RSPO in Colombia } \\
\text { - Interviews with key informants. }\end{array}$ \\
\hline
\end{tabular}


In line with these notions of environments and territories, this dissertation departs from two premises that address the ecology element:

i) the expansion of commodity frontiers produces a socio-physical transformation of the environments or territories where such expansion occurs, and

ii) the physical features and requirements of both the commodity and the process of its production or extraction shape such socio-physical transformation.

Because of practical constraints (lack of technical knowledge and limited budget) I could not incorporate a technical assessment of the biophysical effects of the expansion of the palm oil frontier, both at the national scale, and in the local sites of fieldwork. However, I relied upon secondary data sources, the narratives of the interviewees and my own observations to document the physical (and visual) transformation that the industrial cultivation of oil palm entails. I also document how the characteristics of the commodity and the requirements of its production shape the expansion of the frontier and the production of landscapes with specific characteristics (Chapters 3 and 5).

\subsubsection{Unpacking categories of actors:}

This dissertation uses the categories of: peasants or campesinos; indigenous; AfroColombian communities; local actors; civil society organizations; government; and, agroindustry to refer to different groups of actors that are relevant in the analysis. These categories are not uncontested as these are not homogeneous groups. Under-appreciation of internal divisions and differentiation across gender, class stratification or ethnicity within these categories may result in an over-generalization. This may result in "skewed and unrealistic diagnoses of the social and economic structure" of these groups (Robbins, 2004: 58). In this dissertation, I use these categories for analytical purposes so that they represent the positions of different actors involved in the processes of expansion and contestation of the palm oil frontier.

I am aware of the limits of this dissertation in this regard. Unpacking the categories used in this dissertation to refer to individuals or human groups resisting the threats to livelihoods posed by the expansion of the palm oil frontiers (peasants, campesinos, indigenous, afroColombians, local actors, local populations, subaltern groups) could:

i) bring relevant insights on the internal politics that shape the forms and outcomes of resistance, and

ii) could result in a better understanding of how differentiated actors within those categories experience injustices differently in practice. 
Likewise, the governmental agencies and the agro-industry are made of individuals and organizations that are not homogeneous. For example, within the government there may be dissident voices with regard to specific policies and their implementation. Moreover, there may also be dissident voices within structures of the state other than the government, such as the courts. Identifying internal tensions and differences within the government and the state may further explain the politics of palm oil expansion in Colombia. However, undertaking the analysis of internal politics and differentiation within these categories would have required another type of research design. Rather than dismissing such analysis, I consider it as a relevant subject for future research.

\subsubsection{The case study timeframe:}

The expansion of commodity frontiers, as well as the socio-environmental change it entails, is a continuous dynamic historical process as demonstrated by Moore's study on the sugar frontier (Moore, 2000). The expansion of the palm oil frontier in Colombia analysed in this dissertation is also an ongoing process. Therefore, there is a need to place the case study in a timeframe for practical reasons. The timeframe of the case study presented in this dissertation covers the period between the years 2000 and 2010. The focus on this period allows observation of the remarkable expansion of the palm oil frontier that occurred during Alvaro Uribe Vélez's two successive governments between 2002 and 2010 (see Chapters 3 and 4). However, I present the historical background of the palm oil agro-industry in Colombia in Chapter 3. In the epilogue I provide a brief update of the developments after 2010 to the end of 2013.

\subsubsection{Reflexivity}

The research that is guided by a reflexive model of science requires the exercise of reflexivity along the entire research process in order to be cognisant of, and transparent about:

i) the power effects in the practice of reflexive science (see Table 2.1) and

ii) the effects that the 'positionality' of the researcher have on the research process and its outcomes.

Intellectual honesty requires reflexivity, not only to be practiced, but also to be made public. As Nouwen points out: "Reflexivity reveals the process through which the author has come to understand the issues in the way that she does. Without the author's public reflexivity, the reader sees only the scene painted by the author. The author's public reflexivity allows the reader also to see the window that frames the author's view" (Nouwen, 2013: 21). In this section I make public some of my reflections on my 'positionality' and how it influenced my research. 
My epistemological engagement with the 'epistemologies of the South' involved conducting this research from the standpoint of the subaltern and marginalised groups represented by the local populations whose livelihoods have been threatened by the expansion of the palm oil frontier (see Section 2.3.1). Thus, this standpoint entailed:

i) giving privilege to the voices and views of these subaltern groups over those of the palm oil agro-industry and the government, and

ii) unveiling the social and structural processes that underlie both the expansion of the palm oil frontier and the effects of this expansion on access to resources by, and the livelihoods of, local populations.

This standpoint had important implications for the fieldwork. I gave privilege to fieldwork interventions with local populations involved in conflict and resistance in connection with the expansion of the palm oil frontier and not those who have opted to be incorporated into oil palm chains. However, at the same time, I sought to enter into contact with the actors driving the expansion of the palm oil frontier - the palm oil agro-industry and the government - in order to investigate how their actions, views and positions mediated such expansion and affected local populations.

The access to these different actors and my interaction with them was mediated by both contextual factors and my "embodiment and biography" which defined a field of power relations in which my position changed in different settings and vis-a-vis different interviewees and informants.

\subsubsection{Doing fieldwork in the Magdalena Medio:}

During the second fieldwork period, I paid field visits to two municipalities (San Alberto and Sabana de Torres) of Magdalena Medio sub-region in the Central Region of the palm oil geography. These two municipalities were the field sites where the two peasants association involved in two of the cases of conflict and resistance I had selected to investigate were located. There were two contextual factors influencing my position during the fieldwork in the Magdalena Medio.

Firstly, the presence of the generalised armed conflict and illegal armed groups. The Magdalena Medio is one geographical regions in Colombia hardly affected by generalised armed conflict (Molano Bravo, 2009a). Moreover, there has been a strong presence of 
illegal paramilitary groups in San Alberto and Sabana de Torres since the 1990s, and local populations have experienced and witnessed much violence. ${ }^{15}$

Secondly, the expansion of oil palm cultivation was a sensitive topic because it was (and still is):

i) the subject of a polarised discussion throughout society in Colombia between those against and those in favour of the expansion, and

ii) a sensitive issue since cultivation is controlled and driven by powerful families or business groups, and in some case even by illegal armed groups (see Chapters 3 and 4).

Some elements of my "embodiment and biography" also influenced my position during the fieldwork. I am a woman born and raised in a middle class family in a large city of Colombia. I was intellectually trained as a lawyer in a Colombian university, and enrolled in a doctoral programme at a European university. These biographical characteristics influenced the perceptions that different interviewees and informants had about me. These characteristics also shaped my own perceptions and feelings about different situations and actors during the fieldwork, and the lens through which I observe and frame these situations and position actors.

In the remainder of this section I describe in more detail how these contextual factors and biographical characteristics had an influence in my position during the fieldwork in the Magdalena Medio.

Due to the two contextual factors I mentioned at the beginning of this section 2.4.3.1, I was concerned about:

i) my own safety,

ii) how to gain access to, and approach, the different actors involved in the cases of conflict and resistance I had decided to focus on for this thesis, and

iii) the potential risks that the research could pose to respondents.

Getting access to the field sites proved to be a challenge. My access to San Alberto and Sabana de Torres, and the establishment of contact with the peasant associations, depended on organizations and individuals willing to introduce me into these field sites (see Section

\footnotetext{
${ }^{15}$ I got to know about the presence and effects of the generalised armed conflict in San Alberto and Sabana de Torres from the information I had collected during the exploratory fieldwork and my readings and interviews in preparation for the fieldwork.
} 
2.3.1). However, I found little support from the organizations I had identified during the exploratory fieldwork as potential entry points.

My entry to the field sites was mainly facilitated by key informants who were working, or had worked, for non-governmental organizations supporting the claims of the peasant associations at the time of the fieldwork. These key informants made phone calls to the leaders of the peasant associations to introduce me. One local NGO put me in contact with a person working for that organization who could introduce me to local actors in San Alberto. This person was with me only during the first field visit to San Alberto. Therefore, I was on my own in the other field visits.

The way I entered into the field sites defined my standpoint and my position vis-à-vis the local people. As Burawoy points out, "we don't have access to some Archimedean standpoint; we are always inserted somewhere in the site, which has grave consequences for what we see" (Burawoy, 2009: 204). Since my entry into the field sites had been facilitated by persons and NGOs working with the local populations, my standpoint in the field sites was that of the local people. As a consequence, I collected observations, views and stories about how the expansion of the palm oil frontier is experienced by local people in San Alberto and Sabana de Torres, which probably I could not have had access to if my field visits would have been facilitated by palm oil companies. Thus, my analysis in this dissertation about of the expansion of palm oil frontier and the effects on local people's livelihoods probably differs to a great extent from an analysis of somebody whose entry to localities of oil palm cultivation is facilitated by the palm-oil agro-industry or the government.

Together with my biographic characteristics, the way I entered into the field sites and did my field visits influenced my position during the fieldwork in San Alberto and Sabana de Torres. My biographic characteristics certainly placed me in a privileged position vis-à-vis the local populations and members of the peasant associations of San Alberto and Sabana de Torres. While I am a middle class Colombian doing a doctorate in a European University, these populations have experienced and witnessed the violence of the generalised armed conflict. They have had to confront relatively powerful actors in their struggles to protect their lands, lives and livelihoods.

However, being a woman doing fieldwork alone about a sensitive topic in risky towns changed my apparent position of privilege during the field visits. Despite being Colombian, I felt vulnerable and as a stranger during the field visits in San Alberto and Sabana de Torres. I think that this tension between my privileged status and my vulnerable position during the field visits also influenced my interaction with the local people I established 
contact with. They saw I arrived in town by public transport, rather than the four-wheel drive vehicles associated with NGO workers and palm oil company employees and saw me trying to find my way on my own. It was clear to them I represented neither the agenda of NGOs, nor the agenda of the palm oil companies and the government.

I also made clear that I had no power to influence any change in policies or to support them in the legal processes they were involved in. I was there to understand transformations taking place in my own country. However, people outside of the palm oil nexus would be able to read about their situation which might be able to bring pressure to bear on their side.

As a result, our interaction was transparent, smooth and fluid. Yet I experienced some contradictory feelings.

On the one hand, I perceived that in the specific setting of the field visits the local people with whom I interacted with had power over my position in the field and were much stronger than me. Their social embeddedness in the community meant they knew where, how, when and with whom it was safe to meet. I felt that, to a great extent, my schedule, and more importantly, my safety depended on them. Moreover, I had the perception that they had experienced so much violence and overcome so many difficulties that they were not any longer afraid of expressing their views and had an overwhelming inner strength. They were actually not afraid of talking openly about their conflicts with a large-scale palm oil company. They gave permission for me to record their views without asking to remain anonymous. Some of them even explicitly asked for their story to be made public.

On the other hand, I was emotionally affected by the experience of violence and marginalization they have gone through, and felt guilty because my fieldwork represented a non-justified intrusion in their personal lives and suffering through what Burawoy calls "symbolic violence, exploiting the goodwill of others for our own ends" (Burawoy, 2009: 268). This feeling of intrusion and guiltiness corresponds with what Nouwen (2013) calls "the disturbing experience of the predatory character of fieldwork" (Nouwen, 2013: 21).

I still experience these contradictory feelings, and I do not think there is a way to overcome these contradictions. However, I think that by making these feelings and contradictions explicit I "give expression to the two souls that dwell in many scholars: the one that wants to clarify and explain; and, the one that is confused by the complexity of the issues confronted" (Nouwen, 2013: 11).

\subsubsection{Interviewing the palm oil agro-industry and the government:}

Gaining access to the representatives of the palm oil agro-industry and the government was as difficult as getting access to the field sites and local people during for the fieldwork in Magdalena Medio. The difficulties are rooted in what my 'embodiment and biography' 
represents (or not) for the palm oil agro-industry and the government. I was a Colombian doctoral student affiliated to a foreign university whose research was not part of any large technical project that could represent a benefit for the agenda of these actors. This embodiment placed me in a position of disadvantage to gain access to the palm oil agroindustry and government. My position became evident in the struggle to obtain appointments for interviews with:

i) Representatives of the palm oil company involved in the two cases of conflict I was investigating in San Alberto and Sabana de Torres,

ii) The National Federation of Oil Palm Growers - Fedepalma,

iii) The Ministry of Environment, and

iv) The Ministry of Agriculture and Rural Development.

It took me several months to get an appointment with the representatives of both the palm oil agro-industry and the Ministry of Environment. I was not able to get an appointment with an officer of the Ministry of Agriculture and Rural Development.

Both my biography and my standpoint influenced my interaction with the interviewees. My background as a lawyer and my role as a researcher facilitated the interactions with the representatives of the Ministry of Environment. However, the interaction with the representatives of agro-industry represented a personal challenge due the standpoint from which I approached the research. I had to overcome my own negative preconceptions regarding the palm oil agro-industry in order to establish a dialogue fruitful for my research.

Since I had worked as a lawyer for private companies in the past, I relied on the knowledge that I have obtained from that experience in order to establish a polite and professional interaction in which private sector managers feel comfortable and prepared to share information and express opinions. My effort to detach from my prejudices and establish a dialogue between professionals proved to be successful during the interview with the representative of Fedepalma. I was positively surprised by the openness and transparency of the person I talked to. However, as the interview progressed it became clear to me that to a great extent this person was repeating a sort of script in defence of the palm oil agroindustry and the palm oil expansion, as it was required by his role. Having said that, this person was, (from preconceived notions) surprisingly, also open to discuss more polemic issues about the agro-industry and the effects of the expansion at the local level.

In contrast, the interaction and mood during the interview with the representative of the palm oil company was tense. In this interview I experienced power relations manifesting in a clear manner. The person I interviewed was a manager in a high position in a large-scale 
palm oil producing company belonging to a powerful business group in Colombia. Even before we started the interview, he made me feel the power of his position. He was not available at the time of the appointment and made me wait for about one hour.

Once he became available he said that he did not remember that we had an appointment, even though he had fixed the appointment personally the day before. During the interview, his position of power in representation of a powerful company vis-à-vis my position as a researcher was also clear.

He mentioned that when somebody approached the company for research purposes, the researcher and the company should agree on the research plan which the company would supervise and help the researcher to realise. Therefore, he wanted to see my research plan. I tried to explain that I was there for an interview for my own research project and not to plan or agree on a research project with, or for the company. He accepted to respond my questions unwillingly, and his answers were elusive.

When I asked if the company had been involved in any conflict with local populations, he categorically denied it. This answer closed any possibility to discuss the views of the company on the cases of conflict and resistance I was investigating. However, I did not take the outcome of this interview as a defeat as regards the collection of important information for my research. I rather took this experience as lesson about the challenges that dealing with power pose to researchers since "the rich and the powerful have more to hide and do not readily consent to our scrutiny" (Burawoy, 2009: 268). 


\section{Chapter 3}

\section{Trajectories of Expansion of the Palm Oil Frontier in Colombia: Markets, Places, Land Control and Resistance}

\subsection{Introduction}

In this chapter I address Research Sub-question 1 of this dissertation: How does the global expansion of commodity frontiers interact with national geographies and socio-economic and political processes to produce country-specific trajectories of expansion and resource access control? I do so by drawing on the case of the contemporary expansion of the palm oil frontier in Colombia (2000-2010).

The expansion of commodity frontiers is the process of "production and distribution of specific commodities, and of primary goods in particular, that ha[s] restructured geographic spaces in such a way as to require further expansion" (Moore, 2000: 410). The expansion of a commodity frontier involves ecological changes and demands access to natural resources along different processes of the commodity chain - from extraction (the extraction frontiers) to disposal - that often result in severe socio-environmental impacts in specific sites at the local level. As place-specific resources and ecologies constitute the basis of local people's livelihoods, expansion of commodity frontiers makes a boundary between different landscapes and is at the basis of socio-environmental conflicts (Conde and Kallis, 2012; Martinez-Alier, 2002; Muradian et al., 2012).

One manifestation of the current dynamics of global capitalism is an accelerated expansion of 'commodity frontiers' (Muradian et al., 2012: 561). However, country-specific geographies, social, political and economic processes shape the ways in which the global expansion of a specific commodity frontier unfolds in a particular country.

In this thesis, I use the concept of 'country-specific trajectories of commodity frontiers expansion' to refer to the specific ways in which the expansion of commodity frontiers unfolds in a particular country. Country-specific trajectories involve different practices in order to gain, control or maintain access to a resource, and different responses from local actors situated in the places where expansion takes place. Thus, they are context-specific. Nevertheless, the study of the ways in which commodity frontiers expand in specific countries and contexts contributes to: 
i) a better understanding of the complex and interrelated strands that link up local socio-environmental conflicts at the local level with broader processes at national and global levels; and

ii) the design and implementation of political action that considers the differences and commonalities among countries/localities in order to accommodate strategies at different scales appropriately.

The rate and scale of the global expansion of the palm oil frontier across countries that represent very different contexts make a good case in which to study country-specific trajectories of commodity frontiers expansion and how they are shaped by national geographies and social, political and economic processes taking place at different scales.

The global palm oil market has experienced a remarkable boom since the year 2000. Global production increased from 21.8 million tonnes in 2000 to 45.8 million tonnes in 2010 (Oil World, 2001 and 2011). The rise in palm oil production has led to an accelerated (actual or planned) expansion of oil palm cultivation in producing countries, raising questions about the resulting socio-environmental impacts at the local level. The palm oil industry, governments of palm oil producing countries, and multilateral organizations, such as the World Bank and the Inter-American Development Bank defend expansion of oil palm cultivation on the basis of the potential benefits for rural development and poverty alleviation (Ayodele, 2010; WB and IFC, 2011; World Growth, 2009). However, a wide range of articles and reports from non-governmental organizations (NGOs) and the media, as well as, empirical academic research, have documented potential and actual negative effects of oil palm expansion at the local level which, in some cases, have resulted in socioenvironmental conflicts (Colchester et al., 2006; Friends of the Earth et al., 2008; Julia and White, 2012; Mingorance, 2006; Sheil et al., 2009; The Rainforest Foundation UK, 2013; Wakker, 2005;).

Palm oil has been traditionally used as a raw material for the production of food, soap, cosmetic and oleo-chemical products. It has been increasingly used for biofuel production since the beginning of the 2000s. Since palm oil is used as a feedstock for biodiesel production, the contemporary global expansion of the palm oil frontier has been associated with the global biofuel boom, i.e. the policy-driven increase in biofuel demand and production at global scale that started at the beginning of the $21^{\text {st }}$ century (Borras et al., 2010; Clancy, 2013; Dauvergne and Neville, 2010; FAO, 2008 and 2012; White and Dasgupta, 2010). ${ }^{1}$

\footnotetext{
${ }^{1}$ I use the term policy-driven because the increasing global biofuel demand and production since 2000 have been strongly influenced by policies.

By 2007, blend mandates had been enacted or under consideration in at least 27 countries, and at least
} 
Biofuel mandates and policies stimulating demand and enabling large scale production especially those adopted in the European Union (EU) - have been blamed for the socioenvironmental negative impacts of palm oil expansion in producing countries (Bailey, 2008; Monbiot, 2005; Rice, 2010; Whittington, 2009; See also Pye, 2010 for a detailed account on activism against the EU biofuel policy). However, the ways in which the biofuel and palm oil booms unfold in each palm oil producing country are shaped by country-specific geographies and political economies resulting in country-specific trajectories of expansion (Dauvergne and Neville, 2010; Hall, 2011; White and Dasgupta, 2010).

Palm oil production especially takes place in the Global South in tropical areas of Africa, Asia and Latin America where the appropriate agro-climatic conditions are found to grow the oil palm tree. Palm oil is produced in about 17 countries in these regions. Indonesia, Malaysia, Thailand, Nigeria and Colombia are the world's five leading producers. As Indonesia and Malaysia account for about $85 \%$ of the global palm oil production (Abdullah, 2011), the expansion of the palm oil frontier in these countries has caught most of the attention of the scholarship on the political economy/ecology of the contemporary palm oil expansion (Cooke, 2002; Cramb and Curry, 2012; Julia and White, 2012; McCarthy, 2010; McCarthy and Cramb, 2009; Pye, 2010). There are only a few political economy/ecology studies about the contemporary expansion of the palm oil frontier in other producing countries (See for example Alonso-Fradejas, 2012 on the palm oil expansion in Guatemala, and Curry and Koczberski, 2009 in Papua New Guinea).

Colombia is a relevant case for analysing how the global expansion of commodity frontiers is manifested in country-specific trajectories of control over access to resources, and contestation. It is one of the world's leading producers of palm oil and the expansion of the frontier accelerated across a large area between 2000 and 2010. Moreover, the country has been repeatedly cited in negative terms in the literature dealing with the socioenvironmental impacts of palm oil expansion (Mingorance, 2006; WRM, 2006; Álvarez, 2008). The level of unease arising from the expansion of palm oil cultivation in Colombia can be gauged by the fact that the former United Nations Special Rapporteur on the Right to Food (Jean Ziegler) included the advance of oil palm cultivation in Colombia as a case of special concern in terms of land appropriation and human rights violations in two of his reports (UN, 2007 and 2008).

The academic research related to the dynamics of expansion of the palm oil frontier in Colombia has focused on three aspects:

fourty countries had some form of biofuels promotion (Rothkopf, 2007; FAO, 2008). 
i) the assessment of land use change from a land cover perspective (Castiblanco et al., 2013),

ii) specific local case-studies (Álvarez, 2009; Cárdenas, 2012; Carvajal, 2012; Franco and Restrepo, 2011; García Reyes, 2011; Goebertus, 2009; Gómez-López, 2010; Hurtado and Hernández-Salazar, 2010; Pérez Castro, 2012; Restrepo, 2004); or

iii) the connection with either the biofuel policy and production (Coronado Delgado and Dietz, 2013; Mejía Alfonso 2010; Pérez-Rincón, 2008) or with the internal armed conflict (Franco and Restrepo, 2011; Ocampo Valencia, 2009; Segura, 2008).

Thus, these studies provide a rather fragmented view of the trajectories of expansion of the palm oil frontier in Colombia. In this chapter I attempt to overcome this shortfall by exploring in a comprehensive way the trajectories of the contemporary expansion (20002010) of the palm oil frontier at national scale bringing together these disparate strands into a coherent narrative. Drawing upon the existing research, fieldwork data and an extensive literature review I use an analytical framework grounded in the fields of political economy and political ecology (Fig. 3.1).

This chapter is structured as follows: In Section 3.2 I explain the conceptual and analytical framework used to operationalize the concept of commodity frontiers for the analysis of country-specific trajectories of expansion. Section 3.3 provides a brief historical background to the expansion of the palm oil frontier in Colombia. Section 3.4 contains the findings and discussion about the country-specific trajectories of the expansion of the palm oil frontier at the national scale. The Chapter finishes with some conclusions about both the case of Colombia and the interaction between the global expansion of commodity frontiers and country-specific trajectories of expansion and resource access control (Section 3.5).

\subsection{Conceptual and analytical framework: trajectories of commodity frontiers expansion and land control}

Moore (2000) coined the concept of 'commodity frontier' for the study of world capitalist expansion as a socio-ecological process, defining frontier as a "zone beyond which further expansion is possible". The 'frontier mode' of capitalist expansion takes place through commodities production and distribution organized in commodity chains. ${ }^{2}$ Thus, the concept of commodity frontier incorporates two spatial dimensions, a 'space-of-flows' and 'space-of-place' (Moore, 2000: 412).

\footnotetext{
${ }^{2}$ See Chapter 2, Section 2.1 for the definition of 'commodity chain' used in this thesis.
} 
The 'space-of-place' refers to the geographical places where the different processes of commodity chains operate and expand. In the case of an accelerated expansion of cropbased commodity frontiers - such as the expansion of the palm oil frontier during the $2000 \mathrm{~s}$ - the 'space-of-place' dimension is captured well by Hall's concept of 'crop booms': “crop booms may be defined as taking place when there is a rapid increase in a given area in the amount of land devoted to a given crop as a monocrop or near-monocrop, and when that crop involves investment decisions that span multiple growing seasons (usually because it is a tree crop that takes some years to grow to maturity and begin producing)" (Hall, 2011: 840).

The 'space-of-flows' refers to the "forward movement of the capitalist system" (Moore, 2000: 412). In Castells' words, "the space-of-flows represents the material arrangements that allow for simultaneity of social practices without territorial contiguity" (Castells, 1999). As markets are the main spaces through which capital operates and expands alongside the 'space-of-place', the markets through which commodities flow from extraction to consumption represent the main 'space-of-flows' of commodity frontiers.

The expansion of a global commodity frontier may occur as a gradual and lengthy process if seen from a long term perspective, as shown by Moore in his study about historical global expansion of the sugar frontier (Moore, 2000). However, the long term expansionary process does not occur evenly across time and space. Commodity frontiers may pass through periods of accelerated expansion, like the contemporary expansion of the palm oil frontier, followed by periods of consolidation and quiescence. Furthermore, expansion may be more accelerated, concentrated and /or intense in some regions, countries and localities than in others. It may also take different forms in terms of resource access control in different countries, and may result in different responses from the part of local people.

I call these variations country-specific trajectories of commodity frontier expansion. These particular trajectories are rooted in country/local-specific geographies, and social, economic, and political processes. The characteristics of the commodity also shape the resulting geographies and 'space-of-flows' connected with the frontier expansion (Hall, 2011).

The concept of 'flex crops' illustrates well the relevance of the features of crops the produce of which may serve different markets, such as oil palm. Borras et al., (2012: 851) define 'flex crops' as "crops that have multiple uses (food, feed, fuel, industrial material) that can be easily and flexibly inter-changed". Oil palm, soy, corn or sugarcane, are all examples of flex-crops. Due to their versatility, the emergence of 'flex crops' at global scale is a logical outcome of the current dynamics of global capitalism represented by: 
i) "the convergence of multiple crises: food, energy, climate change and finance capital" (Borras et al., 2012: 846); and

ii) a paradoxical combination of "relative scarcity of natural resources (a regime characterized by high prices) with a tremendous expansion in the production of natural resources" (Muradian et al., 2012: 561).

The 'frontier mode' is one of the forms of capitalist expansion that entails more profound socio-ecological transformations at the sites of expansion (Moore, 2000). Specific local geographies across the processes of the commodity chain are socially and physically modified as the frontier expands in the 'space-of-place' through different mechanisms of resource access control.

In the case of 'crop booms', land control is inherent to the frontier expansion. Peluso and Lund (2011: 668) define 'land control' as "the practices that fix or consolidate forms of access, claiming, and exclusion for some time". Such practices include, not only legal mechanisms established in tenure regimes, but also illegal mechanisms such as fraud, theft, "force, violence or the threat of them" (Peluso and Lund, 2011: 668; Ribot and Peluso, 2003).

This definition of land control is based on Ribot and Peluso's theory of access (see Chapters 2 and 4), according to which access to resources is defined as the ability to benefit from resources (Ribot and Peluso, 2003). Ribot and Peluso distinguish access control from access maintenance. While "access control is the ability to mediate others' access", access maintenance refers to the practices by which people expend "resources or powers to keep a particular sort of resource access open" for themselves (Ribot and Peluso, 2003: 159). Access maintenance entails negotiation of benefits between actors who control access and those who seek to maintain their own access. "To maintain access, subordinate actors often transfer some benefits to those who control it. They expend resources to cultivate relations or transfer benefits to those who control access in order to derive their own benefit" (Ribot and Peluso, 2003: 159). In addition, Ribot and Peluso introduce the term gaining access to refer to "the more general process by which access is established" through different legal or illegal means (Ribot and Peluso, 2003: 159).

Practices of land control used for the expansion of commodity frontiers are practices to gain and control access. These may correspond with global patterns of 'accumulation by dispossession', or 'assimilation'. The concept of 'accumulation by dispossession' refers to processes of capital accumulation by certain human groups at expenses of the livelihoods of others (Harvey, 2003). Practices of 'accumulation by dispossession' that deprive local 
people from the land and resources that constitute the basis of their livelihoods may result in resistance as a strategy to maintain access to such land and resources, so leading to socioenvironmental conflicts. ${ }^{3}$ However, gaining and controlling access to resources for the expansion of a commodity frontier may also proceed through 'assimilation' practices. According to Escobar (2006a and 2006b), 'assimilation' is represented by forms of inclusion that deny and erase difference in culture and identity. Practices of 'assimilation' not only deny difference, but also may derive in 'adverse incorporation', i.e. inclusion in disadvantageous terms (Hickey and du Toit, 2007; McCarthy, 2010). Some local people may resist against 'assimilation practices', while others may accept this type of inclusion in order to maintain access to the land and resources that sustain their livelihoods.

A way to identify country-specific trajectories of a commodity frontier expansion and their interaction with broader processes at different scales is by unpacking the 'commodity metabolism'. I use here the term 'commodity metabolism' to refer to the flows along the commodity chain from extraction to destination markets (Conde and Kallis, 2012). ${ }^{4}$ Using this approach it is possible to identify:

i) the configuration of the 'space-of-flows' represented by the markets to which a commodity is directed; and

ii) the country-specific geographies of the expansion, i.e. the 'space-of-place' represented by the extraction frontier and the related dynamics of resource control and resistance.

Fig. 3.1 is a graphic representation of this analytical approach, showing how the different concepts presented in this section interrelate. In this chapter I follow this analytical strategy in order to identify the markets and geographies that define the country-specific trajectories of the palm oil frontier expansion in Colombia, and their connections with general patterns of resource control associated with the 'frontier mode' of expansion.

\footnotetext{
${ }^{3}$ See Chapter 2 - Section 2.2 for a more detailed explanation of the concepts of 'accumulation by dispossession' 'assimilation' and 'socio-environmental conflicts'.

${ }^{4}$ See Chapter 2 - Section 2.1 for the definition of 'commodity chain' used in this dissertation.
} 
Fig 3.1. Analytical and conceptual framework: 'commodity metabolism' for the study of country-specific trajectories of commodity frontiers expansion

Local Effectswith impacts on livelihoods

Accumulation/contamination by dispossession + Resistance $=$ socio-environmental conflicts

Assimilation and/or Adverse incorporation

\section{COMMODITY METABOLISM}
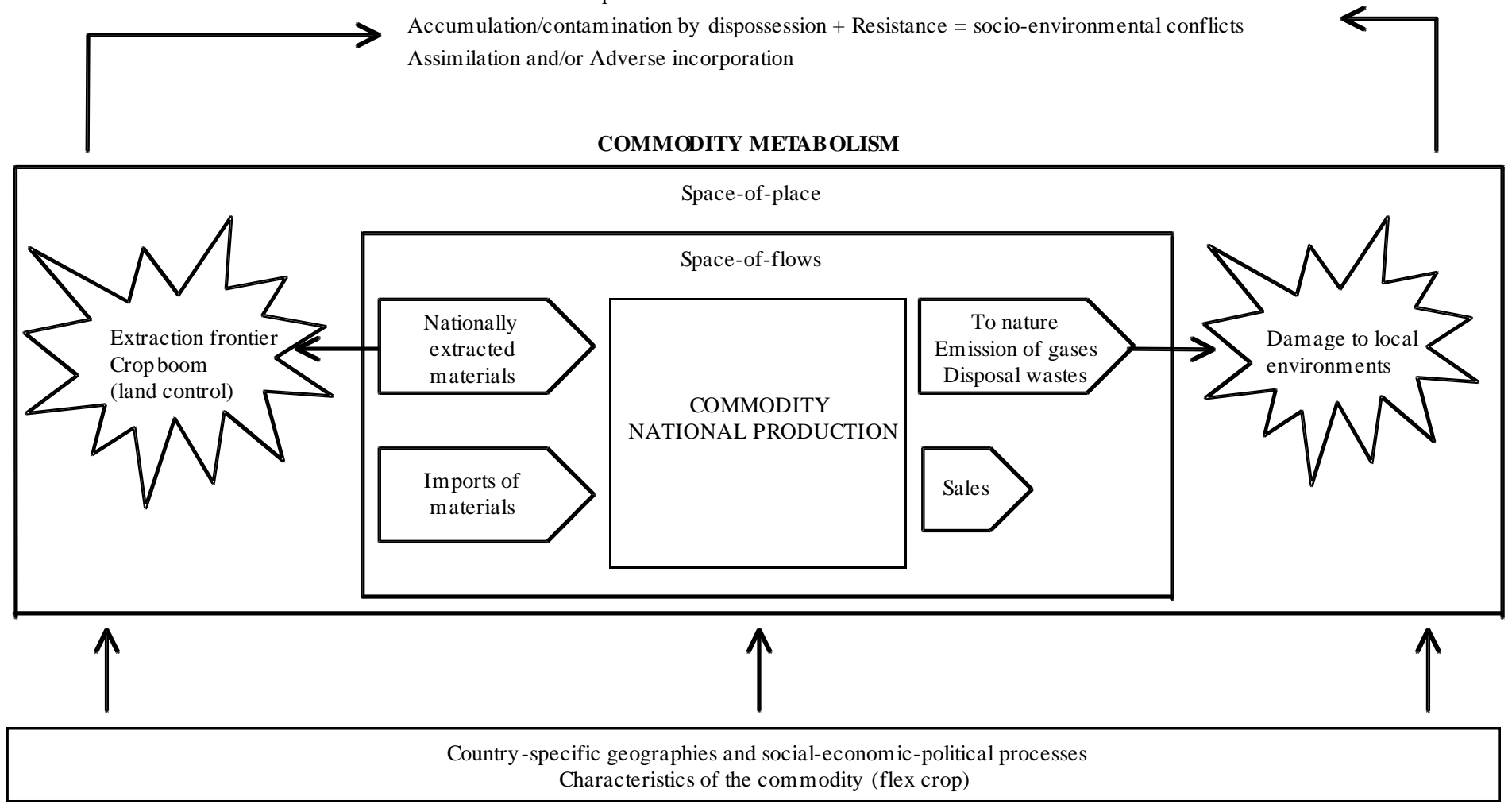

Source: own construction. 


\subsection{Overview of the expansion of the palm oil frontier in Colombia}

Colombia is currently the fifth leading producer of palm oil in the world (in terms of volume) and the largest in the Americas. The agri-business of oil palm cultivation and palm oil production started to consolidate in the 1960s, although the first plantations started as early as 1945 (Aguilera, 2002; Ospina Bozzi, 2007; Vargas Tovar, 2002). Since then, oil palm cultivation has grown continuously, although not evenly. It has passed through periods of rise and stagnation depending on governmental support, market changes, and natural and ecological conditions as shown in Fig. 3.2.

Fig. 3.2. Oil palm cultivation in Colombia (hectares planted) 1970-2012

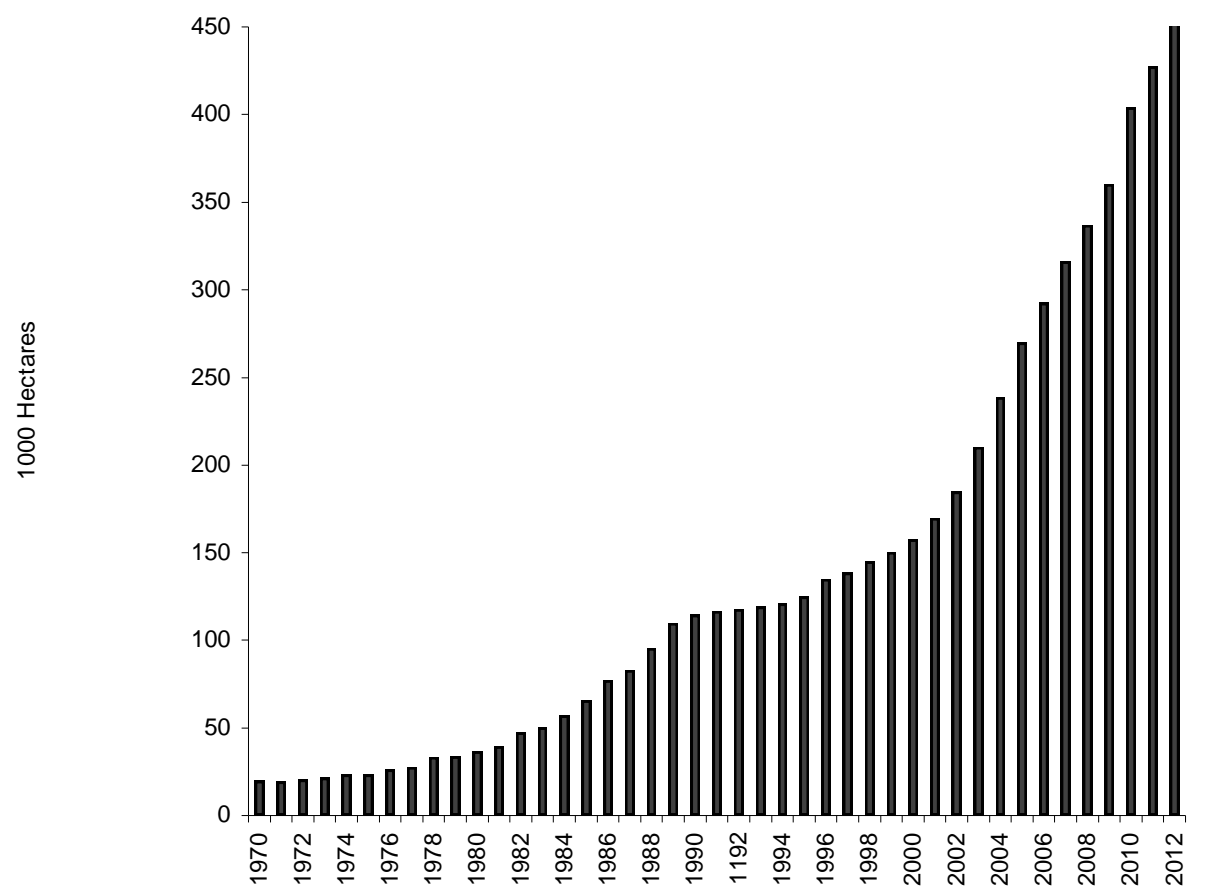

Source: SISPA (Statistics Information System of the Palm Oil Sector). 
Mostly national entrepreneurs started to cultivate and produce palm oil to supply the national market with the support of the national government in the 1960s (Aguilera, 2002; Ospina Bozzi, 2007; Vargas Tovar, 2002). Between the 1960s and the end of the 1980s, governmental support and the protection of the national production through policies to control imports of vegetable oils and fats facilitated the establishment and growth of the national palm oil sector. These policies made it possible to keep palm oil national prices substantially higher than international prices, so protecting the revenues of the national palm oil agro-industry, as shown in Fig. 3.3 (Aguilera, 2002; García Reyes, 2011; Observatorio Agrocadenas, 2006). As a result, oil palm cultivation and palm oil production was consolidated as a flourishing agro-industry controlled by national entrepreneurs and oriented to the national market for traditional uses (food, oleo-chemical, soaps and animal feed).

Fig. 3.3. National and international crude palm oil prices January 1981- January 2004

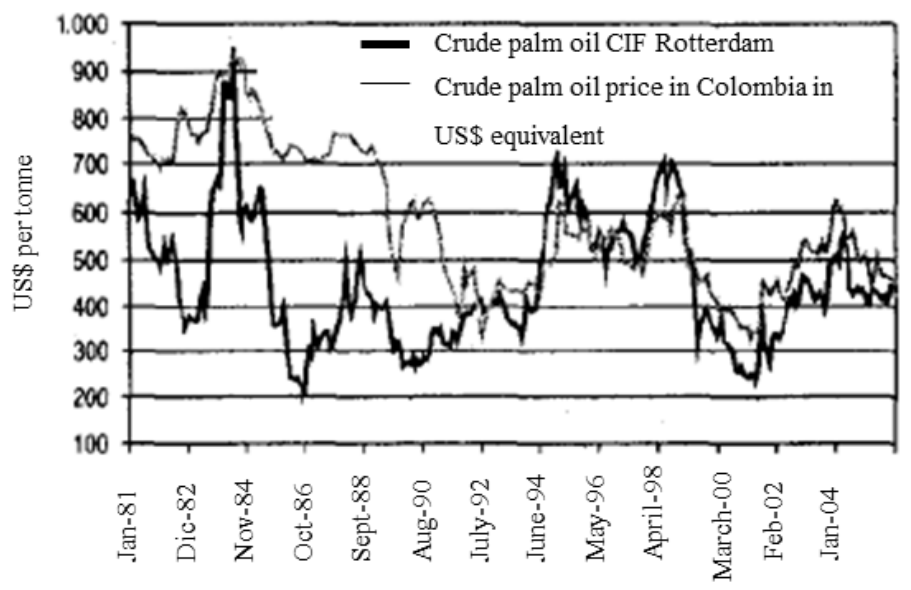

Source: Observatorio Agrocadenas, 2006.

The scenario of prosperity of the 1980 s changed during the 1990 s when a combination of three interrelated factors resulted in stagnation of oil palm cultivation and palm oil production (Aguilera, 2002; García Reyes, 2011; Mesa Dishington, 2009):

i) a commercialisation crisis due to saturation of the palm oil traditional national market (food, oleo-chemical, soaps and animal feed); 
ii) the liberalisation of the Colombian market that allowed imports of vegetable oils from cheaper sources, ${ }^{5}$ and

iii) the lack of governmental support appropriate to the needs of the palm oil agroindustry such as credit lines suitable for late-maturing crops.

However, since 2000 Colombia has followed the global trend of an accelerated expansion of the palm oil frontier. The country-specific trajectories of this expansion are expressed in the 'commodity metabolism' (see Section 3.2) of the Colombian palm oil commodity chain during the 2000-2010 period, which encompasses both the markets where palm oil is directed to (the 'space-of-flows'), and the expansion of oil palm cultivation at the extraction frontier ('space-of-place'), as shown in Fig. 3.4.

This 'commodity metabolism' was characterised by:

i) A substantial increase in palm oil sales for export since 2003. Palm oil sales for export started to decrease in 2008 when sales for the national biodiesel market started to rise.

ii) An accelerated expansion of oil palm cultivation between 2002 and 2010 that entailed access to land through different forms of 'accumulation by dispossession' and 'assimilation'.

The following Section 3.4 presents a detailed account of these trajectories of expansion in the 'space-of-flows' (Section 3.4.1) and in the 'space-of-place' (Section 3.4.2), together with the country-specific geographical, socio-economic and political factors that shaped them.

\subsection{Trajectories of the 2000-2010 expansion of the palm oil frontier in Colombia}

\subsubsection{The 'space-of-flows': markets, 'flex crops', and biofuels}

The 'space-of-flows' of the Colombian palm oil 'commodity metabolism' was limited to the national traditional market (food, oleo-chemical, soaps and animal feed) until the 1990s. However, the commercialisation crisis at the end of the 1980s and the liberalisation of the Colombian market since the beginning of the 1990s (see Section 3.3) led palm oil producers to look for export outlets.

\footnotetext{
${ }^{5}$ By liberalisation of the Colombian market I mean the measures taken by César Gaviria's government (1990-1994) to withdraw the 'import substitution' model based on the protection of the national production, and move towards an open market model in which the national production enters into competition with imports. In the agricultural sector the liberalisation of the market involved the withdrawing of import barriers and agricultural price supports (Kalmanovitz and López Enciso, 2006).
} 
Fig. 3.4. Colombian palm oil 'commodity metabolism'

Local Effectsin rural territories with impacts on livelihoods

Accumulation by dispossession + Resistance $=$ socio-environmental conflicts

Assimilation taking the form of productive alliances

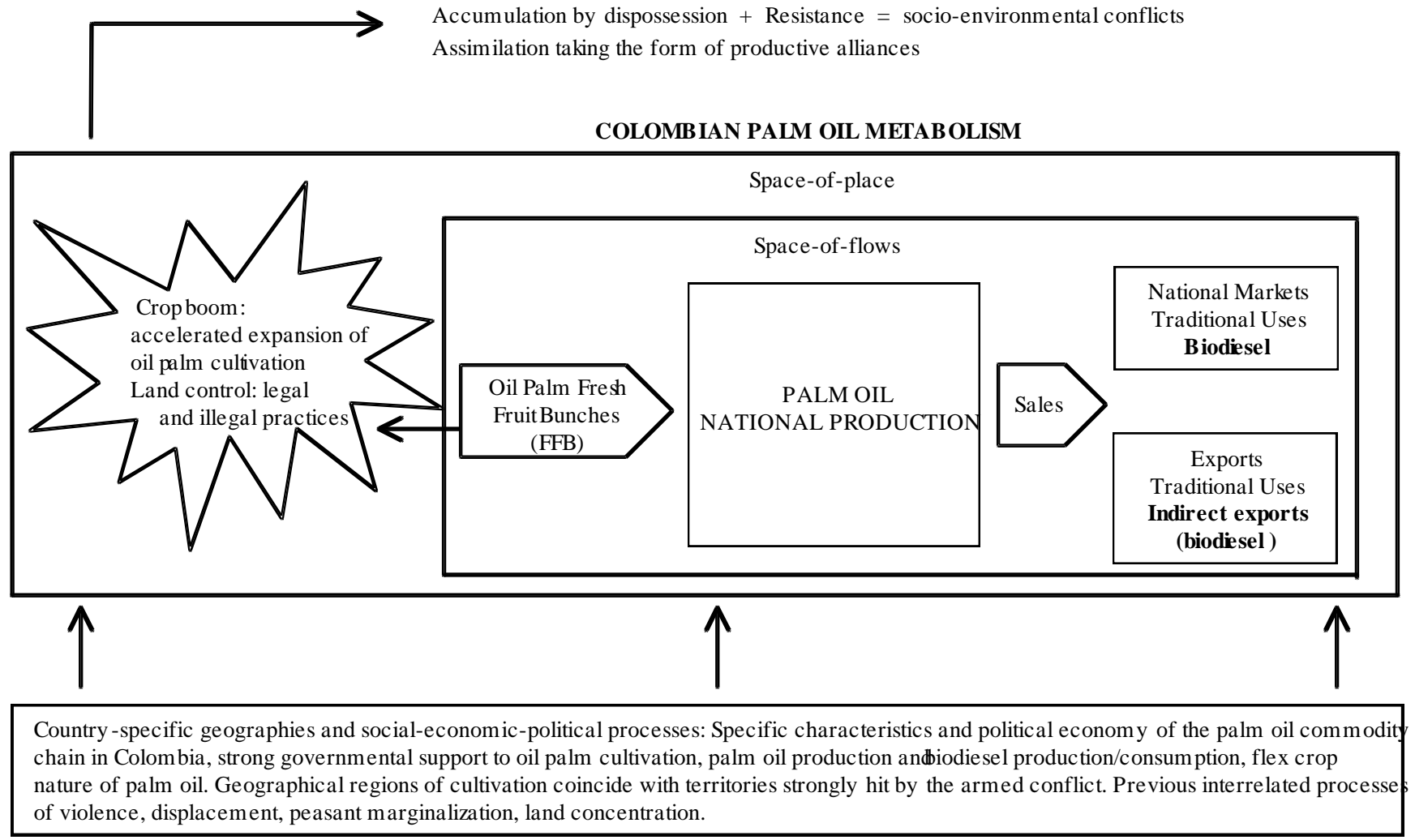

Source: own construction. 
By 1989, the national traditional market could no longer absorb the increasing palm oil production. Moreover, some industries that used to demand palm oil for the production of food, soap, oleo-chemical and animal feed products started to import vegetable oils due to market liberalisation giving access to cheaper sources (Mesa Dishington, 2009). In addition, palm oil producers could no longer rely on the high national prices. National prices adjusted to the international prices because of the liberalisation of the market, as shown in Fig. 3.3 above.

The alternative chosen by the palm oil agro-industry to cope with the commercialisation crisis was to direct the palm oil surplus to export markets. Exports took off since the beginning of the 1990s. A price stabilisation fund was established in 1996 and started operations in 1998 to facilitate exports while the revenues of the palm oil producers were protected (Mesa Dishington, 2009). ${ }^{6}$ However, palm oil produced in Colombia was less competitive in the international market than palm oil from the two global largest producers Indonesia and Malaysia - due to high production costs in Colombia (Mesa Dishington, 2009). ${ }^{7}$

Thus, exporting palm oil was necessary to cope with saturation of the traditional national market but it was not as profitable as selling it in the national market. Indeed, the volume of palm oil exports remained relatively low until the beginning of the 2000 - 2010 decade, and most of the national palm oil production was directed to meet the demand of the traditional national market (food, oleo-chemicals, soaps, animal feed). However, the 'space-of-flows' started to change substantially after 2000. The expansion of the Colombian palm oil frontier between 2000 and 2010 was characterized by a substantial increase in exports until sales to a new national biodiesel market started to rise in 2008, as shown in Fig. 3.5 (see Sections 3.4.1.1 and 3.4.1.2 below).

\footnotetext{
${ }^{6}$ The palm oil price stabilisation fund was created in 1996 to optimize the sales revenues and ensure that all palm oil producers could participate under conditions of equal prices in both the national and foreign markets (http://portal.fedepalma.org//fund.htm. Accessed August 22, 2013). The fund works by collecting resources that come from sales of producers, distributors and exporters to the market with the most convenient price, in order to make compensations for the sales in the market with the less convenient price (Tudela et al., 2004).

${ }^{7}$ The costs of production per tonne of palm oil have been historically higher in Colombia than Indonesia and Malaysia (Corredor Ríos, 2008; Mosquera et al., 2007). A study dated from 2009 reported that the cost of producing a tonne of palm oil in Colombia was around US\$ 340, while in Malaysia was around US\$216, and in Indonesia US\$ 154 (Cenipalma and Fedepalma, 2009).

While Malaysia and Indonesia contributed with $88 \%$ of the total global production of palm oil by 2008, the contribution of Colombia was only of 2\% (Cenipalma and Fedepalma, 2009). Likewise, palm oil sales from Malaysia and Indonesia have represented about $90 \%$ of the global palm oil sales since 2000, while Colombia only contributed $1 \%$ of the global palm oil exports in 2007 (Cenipalma and Fedepalma, 2009).
} 
Fig. 3.5. Colombian palm oil production and sales per market of destination 1998-2010

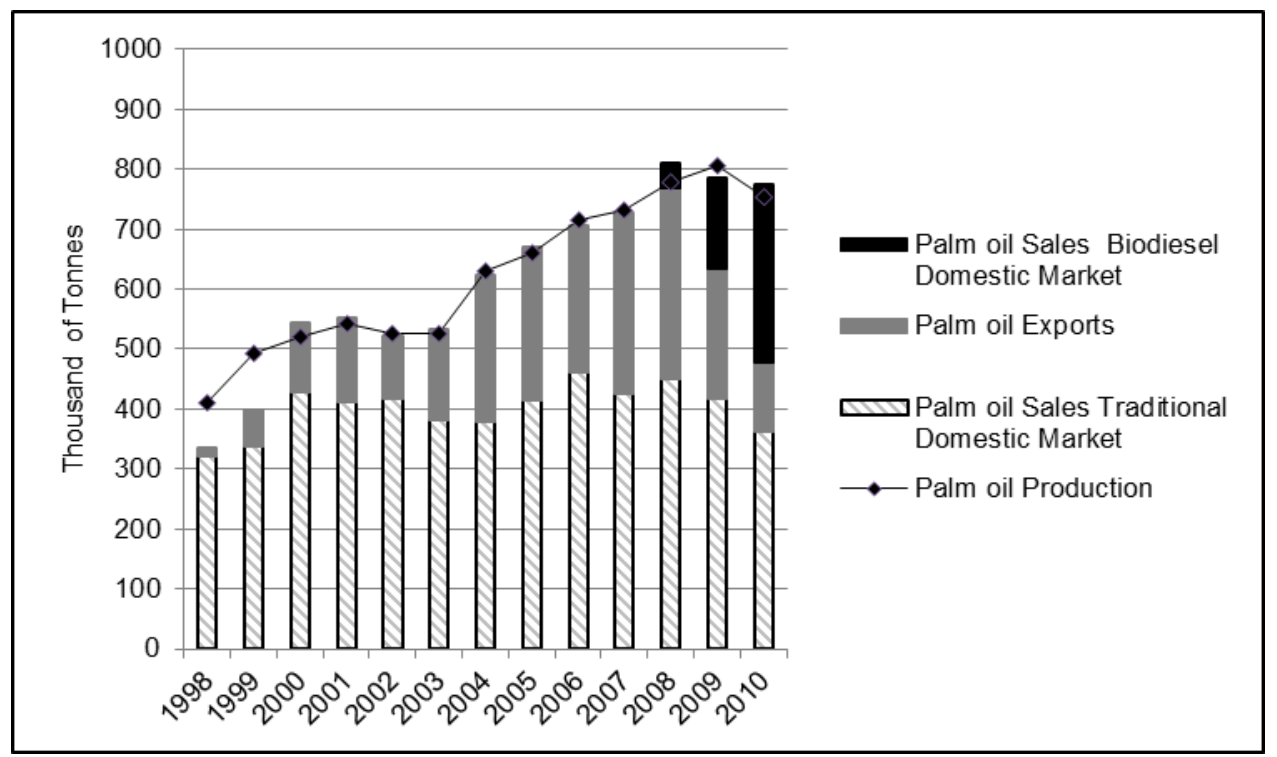

Source: own construction on the basis of data extracted from SISPA (Statistics Information System of the Palm Oil Sector) and Fedepalma, 2009, 2010a, 2011a.

This trajectory of the contemporary expansion in the 'space-of-flows' was shaped by the flexible nature of palm oil as a feedstock and the political economy of the Colombian palm oil commodity chain.

Oil palm is a typical 'flex crop' (see Section 3.2 for the definition of 'flex crops'). From the oil palm fresh fruit bunches (FFB) it is possible to extract raw materials for the food, feed and energy markets. Palm oil is the principal product, but from its extraction also results side products that can be used to produce animal feed (meal and palm kernel meal), and palm kernel oil that is further processed into food products, soap and cosmetics. Moreover, palm oil is a vegetable oil 'flexible' in itself. It can be further transformed into intermediate and final goods for the food, biodiesel, oleo-chemical, cosmetics and animal feed markets. Given the flex-crop nature of palm oil that allows its transformation into biodiesel, expansion of the palm oil frontier in Colombia between 2000 and 2010 was highly influenced by the global biofuel boom that started at the beginning of the $21^{\text {st }}$ century (see Section 3.1 for the definition of the global biofuel boom used in this thesis).

However, the characteristics of the palm oil commodity chain in Colombia and the Colombian biofuels and palm oil political economy shaped the ways in which the global 
biofuel boom resulted in country-specific trajectories of palm oil frontier expansion in the 'space-of-flows'.

Palm oil extraction is the central production process of the commodity chain around which it is possible to integrate the two other main processes: oil palm cultivation at the upstream end of the chain and industrial transformation at the downstream end. Industrial transformation can be further divided in different processes depending on the intermediate and final goods to be produced from processing crude palm oil.

The current organization of the Colombian palm oil sector along the commodity chain is rather complex. By 2010 there were 54 palm oil extraction companies combining different forms of integration with both other organizations and other commodity chain processes around palm oil production (see Table 3.1 for examples of integration of the seven major palm oil producing business groups in Colombia).

However, it is possible to distinguish four distinctive traits in the Colombian palm oil commodity chain:

i) historical control of the different processes by national entrepreneurs, rather than by foreign transnational corporations (Aguilera, 2002; Ospina Bozzi, 2007), most of whom belong to wealthy families that have established prosperous business groups at the national level.

ii) High levels of vertical integration between agro-industrial (oil palm cultivation and palm oil production) and industrial processing activities so that palm oil production is sold directly by palm oil producers to processors that are part of the same business group they are integrated in (Observatorio Agrocadenas, 2006: 60), as shown in Table 3.1 in this section and Table 3.2 in Section 3.4.1.1.

iii) Development of the agro-industrial activities (oil palm cultivation and palm oil production) driven by governmental support.

iv) Low international competitiveness of the Colombian palm oil production and the marginal position in the international market compared to Indonesia and Malaysia.

For such a nationally oriented and highly integrated Colombian palm oil sector, the biofuel boom emerged as a twofold business opportunity for national producers to cope with the commercialisation and competitiveness challenges.

First, as the Colombian president Álvaro Uribe Vélez (2002 - 2010) embraced the global enthusiasm for biofuels, his government promoted the creation of a national biodiesel market that allowed the enlargement of the national market for palm oil. During the 
presidential election campaign, Uribe Vélez had expressed his desire to establish the enabling policy environment to promote national biodiesel demand and production. He kept to this promise once elected (Mesa Dishington, 2009). A blending mandate and tax exemptions were adopted during his government to stimulate the demand for biodiesel (See Chapter 4).

Second, the use of vegetable oils for biodiesel production in other countries - especially in the EU - increased the demand for these commodities in the international market, so creating market opportunities for palm oil exports (FAO, 2008; MVO, 2008, 2009 and 2010).

In order to meet the increased national demand created by the national biodiesel blending mandate and seize the export opportunities, Colombian palm oil producers needed to ensure governmental support.

The governmental support was required to increase oil palm cultivation, enlarge the capacity of palm oil extraction plants, establish biodiesel refineries and be able to compete in the international market. Uribe Vélez's government supported strongly the palm oil sector through credit, subsidies, fiscal incentives, price regulations, and stimulus to facilitate the establishment of biodiesel refineries.

The details about these instruments and the way in which they enabled access to resources, whose access was enabled, and how the beneficiaries were able to influence policy-making and implementation are explained in detail in Chapter $4 .^{8}$

The result in the 'space-of-flows' was a two-pronged trajectory of expansion that:

i) privileged the increase in sales to the national market by establishing a national biodiesel market and industry, and

ii) took advantage of the available opportunities in the international market as long as they were profitable.

\footnotetext{
${ }^{8}$ Governmental support to the palm oil agro-industry during Álvaro Uribe Vélez's government is so relevant to understand the country-specific trajectories of expansion of the palm oil frontier in Colombia that I devoted a complete chapter of this thesis to this topic (see Chapter 4).
} 
Table 3.1. Commodity chain integration of seven major palm oil producers in Colombia in 2010

\begin{tabular}{|c|c|c|c|c|c|c|c|c|c|c|c|c|c|}
\hline \multirow[t]{2}{*}{ Family / Business group } & \multicolumn{3}{|c|}{ OIL PALM CULTIVATION } & \multicolumn{6}{|c|}{$\begin{array}{c}\text { PALM OIL EXTRACTION AND } \\
\text { COMMERCIALIZATION } \\
\end{array}$} & \multicolumn{4}{|c|}{ PALM OIL PROCESSING } \\
\hline & \begin{tabular}{|l} 
Own \\
plantations
\end{tabular} & $\begin{array}{l}\text { 'Productive } \\
\text { alliances' } \\
\text { (see Section } \\
4.4 .2 .1 \text { ) }\end{array}$ & $\begin{array}{l}\text { Supply } \\
\text { agreements } \\
\text { with } \\
\text { independent } \\
\text { growers }\end{array}$ & $\begin{array}{l}\text { Own } \\
\text { plant }\end{array}$ & \begin{tabular}{|l|} 
Plant \\
with \\
other \\
firms
\end{tabular} & $\begin{array}{l}\text { Plant } \\
\text { with } \\
\text { 'productive } \\
\text { alliances' }\end{array}$ & $\begin{array}{l}\text { Own } \\
\text { firm }\end{array}$ & $\begin{array}{l}\text { With } \\
\text { other } \\
\text { firms }\end{array}$ & $\begin{array}{l}\text { With } \\
\text { 'productive } \\
\text { alliances' }\end{array}$ & $\begin{array}{l}\text { Own } \\
\text { firm }\end{array}$ & $\begin{array}{l}\text { With other } \\
\text { firms } \\
\text { ownership }\end{array}$ & $\begin{array}{l}\text { Own } \\
\text { firm }\end{array}$ & $\begin{array}{l}\text { With other } \\
\text { firms } \\
\text { (commercial } \\
\text { alliance) }\end{array}$ \\
\hline $\begin{array}{l}\text { Murgas Dávila } \\
\text { Family. } \\
\text { Oleoflores business group } \\
\text { (Oleoflores) }\end{array}$ & $\checkmark$ & $\checkmark$ & $\checkmark$ & $\checkmark$ & $\checkmark$ & $\checkmark$ & $\checkmark$ & $\checkmark$ & $\checkmark$ & $\checkmark$ & & $\checkmark$ & \\
\hline $\begin{array}{l}\text { Haime Gutt family. } \\
\text { Indupalma/Grasco business } \\
\text { group } \\
\text { (Indupalma) }\end{array}$ & $\checkmark$ & $\checkmark$ & $\checkmark$ & $\checkmark$ & & & $\checkmark$ & & & & & $\checkmark$ & \\
\hline $\begin{array}{l}\text { Eder family. } \\
\text { Manuelita business group } \\
\text { (Aceites Manuelita) }\end{array}$ & $\checkmark$ & & $\checkmark$ & $\checkmark$ & & & $\checkmark$ & & & $\checkmark$ & & & \\
\hline $\begin{array}{l}\text { Dávila Abondano family. } \\
\text { DAABON business group } \\
\text { (C.I Tequendama) }\end{array}$ & $\checkmark$ & $\checkmark$ & & $\checkmark$ & & & $\checkmark$ & & & & $\checkmark$ & $\checkmark$ & \\
\hline $\begin{array}{l}\text { Espinosa family. Espinosa } \\
\text { business group (Palmar del } \\
\text { Oriente; Palmas de } \\
\text { Tumaco) }\end{array}$ & $\checkmark$ & & & $\checkmark$ & $\checkmark$ & & $\checkmark$ & $\checkmark$ & & & $\checkmark$ & $\checkmark$ & $\checkmark$ \\
\hline
\end{tabular}

Source: own construction.

${ }^{1}$ Oleaginosas Las Brisas was liquidated in November 2013. 
Such trajectory of expansion corresponded with the specific characteristics of the Colombian palm oil sector and its position in the international market, as illustrated by the words of the Executive President of the National Federation of Oil Palm Growers (Fedepalma):

Original in Spanish:

"Colombia tiene costos altos de producción...; y sabemos que la competitividad la vamos a alcanzar logrando que el trabajo sea más eficiente y productivo, y buscando nichos de mercado en los que podamos vender nuestros productos a precios rentables para tales costos. Por ejemplo, con el biodiesel tenemos la posibilidad de ampliar nuestra participación en el mercado local, que es el de los mejores precios... Mientras el mercado mundial sea suficientemente grande como para que los productores más competitivos coloquen su producto sin atender toda la demanda existente, el mercado tendrá que pagar el precio de quienes producimos a precios más altos, o corre el riesgo de quedar desabastecido." (Mesa Dishington, 2009: 173)
English own translation:

"Colombia has high production costs...; and we know that we will achieve competitiveness by making the work more efficient and productive, and by finding niche markets in which we can sell our products at prices that are profitable in relation to such costs. For example, with biodiesel we have the possibility of expanding our participation in the local market, which has the best prices... While the global market is large enough for the most competitive producers to place their product without meeting the existing demand, the market will have to pay the prices of those who produce at higher prices as we do, or run the risk of being undersupplied."

\subsubsection{Expansion in the national market:}

The expansion in the national market is represented by the substantial increase in palm oil production and the establishment of a national biodiesel market/industry that increasingly absorbed substantial quantities of palm oil. The law that established a general biodiesel blending mandate was adopted in 2004 (Law 939, 2004), but the specific blending targets started to be gradually implemented since 2008 (see Chapter 4).

As shown in Fig 3.5, palm oil production has risen rapidly since 2003 until a disease that affected thousands of hectares planted with oil palm led to a decrease in palm oil production in 2010. ${ }^{9}$ Likewise, six biodiesel refineries were built and put into operation between 2005 and 2010 .

\footnotetext{
${ }^{9}$ Although the disease known as 'bud rot' started in 2006 in the South-west region of oil palm cultivation, it spread to other regions in 2009 , in particular to the Central region. The accumulated loss
} 
As shown in Fig 3.5, since 2008 the national biodiesel industry started to gradually absorb a larger share of the palm oil sales and production. By 2010, it had already absorbed about $40 \%$ of the national palm oil production and sales (Fedepalma, 2011a). The five operating biodiesel refineries are totally or partially owned by national palm oil producers that are part of national wealthy business groups. ${ }^{10}$ Some of these palm oil producers are vertically integrated with biodiesel production. They are also integrated with other palm oil commercialisation and processing businesses which absorbed another $20 \%$ of the palm oil sales in 2010 (Table 3.2). Thus, by 2010 a national biodiesel industry controlled by traditional national palm oil producers supplied the newly created national biodiesel market, and absorbed a significant portion of the national palm oil production.

\subsubsection{Expansion in the export market:}

During the time required to establish the national biodiesel industry, palm oil producers needed an outlet to place the surplus of increased palm oil production. A biofuel-driven increasing demand for vegetable oils at the international level - especially in the European Union - provided the market opportunities to export such a surplus. Between 2003 and 2008 Colombia palm oil exports more than doubled. However, they started to decrease in 2008 with the implementation of the national biodiesel blending mandate (Fig. 3.5). From 2004 until 2008, most palm oil exports went to the European Union (Fig. 3.6).

Several factors converged to shape this particular exports flow.

First, palm oil exports were favoured by:

i) the increase in international prices (see Fig. 3.7), and

ii) governmental support through a subsidy that partially funded the fees of exchangerate risk coverage instruments as detailed in Chapter 4.

of oil palm hectares reflected in palm oil production decrease in 2010. By 2010, the number of hectares affected with the disease amounted to 40,000 (Cabra Martínez, 2011). The 'bud rot' is an infection that affects the tissues of the oil palm leading to their decomposition and the eventual death of the oil palm. The decomposed tissue attracts insects that disseminate the infection (Martínez López, 2010). The spread of the 'bud rot' disease in Colombia demonstrates that monocultures of perennial crops such as oil palm plantations can be very vulnerable to pests and diseases. "Pests and diseases can become established in perennial crops and affect the crop for many years, as crop rotation, an important pest control strategy for annual crops, is not a short-term option for perennial crops" (Mosquera et al., 2012). Moreover, because oil palm plantations are monocultures that form enclaves, the infection can spread rapidly across plantations. Within few years large extensions of oil palm plantations can be wiped out, as it was the case in the South-west and Central Regions of oil palm cultivation in Colombia.

${ }^{10}$ One of the six biodiesel refineries built between 2005 and 2010 went out of operation in 2012. This was Odin Energy, the only one that was owned by a company of foreign investors (Revista Dinero, 2012). 
Table 3.2 Commodity chain integration of palm oil producers involved in biodiesel production in 2010

\begin{tabular}{|c|c|c|c|}
\hline $\begin{array}{l}\text { Biodiesel } \\
\text { Producing } \\
\text { Companies }\end{array}$ & \begin{tabular}{|l|} 
Percentage Of Palm \\
Oil Sales (In Terms Of \\
Volume) Absorbed \\
For Biodiesel \\
Production In 2010
\end{tabular} & \begin{tabular}{|l} 
National Palm Oil \\
Producers With \\
Participation In Biodiesel \\
Companies
\end{tabular} & $\begin{array}{l}\text { Percentage Of Palm Oil Sales } \\
\text { (In Terms Of Volume) } \\
\text { Absorbed By Other Palm Oil } \\
\text { Processing Or Exports } \\
\text { Businesses Of The Palm Oil } \\
\text { Producers In } 2010\end{array}$ \\
\hline Oleoflores s.a. & $8.1 \%$ & $\begin{array}{l}\text { Oleoflores group } \\
\text { (Murgas Dávila Family) }\end{array}$ & $\begin{array}{l}\text { Oleoflores s.a } \\
1.9 \%\end{array}$ \\
\hline \multirow{3}{*}{$\begin{array}{l}\text { Biocombustibles } \\
\text { Sostenibles del } \\
\text { Caribe s.a. }\end{array}$} & \multirow[t]{3}{*}{$5.5 \%$} & \multirow[t]{2}{*}{$\begin{array}{l}\text { DAABON Group (Dávila } \\
\text { Abondano Family) }\end{array}$} & $\begin{array}{l}\text { C.I Tequendama (processing) } \\
\mathbf{2 . 5 \%}\end{array}$ \\
\hline & & & $\begin{array}{l}\text { C.I Tequendama (exports) } \\
\mathbf{1 . 7 \%}\end{array}$ \\
\hline & & Palmeras de la Costa s.a. & $\begin{array}{l}\text { Palmeras de la Costa s.a. } \\
\mathbf{1 . 2 \%}\end{array}$ \\
\hline $\begin{array}{l}\text { Aceites Manuelita } \\
\text { s.a. }\end{array}$ & $10 \%$ & Aceites Manuelita s.a. & \\
\hline \multirow[t]{7}{*}{$\begin{array}{l}\text { Ecodiesel } \\
\text { Colombia }\end{array}$} & \multirow[t]{7}{*}{$5.5 \%$} & Extractora Central s.a. & \\
\hline & & $\begin{array}{l}\text { Oleaginosas las Brisas s.a. } \\
\text { (Business group CasaLuker) }\end{array}$ & $\begin{array}{l}\text { (CasaLucker is part of Alianza } \\
\text { Team through the Affiliate Grasas } \\
\text { S.A.) Alianza Team absorbed } \\
\mathbf{7 . 3 \%} \text { of the palm oil sales. }\end{array}$ \\
\hline & & $\begin{array}{l}\text { Palmas Oleaginosas } \\
\text { Bucarelia s.a. }\end{array}$ & $\begin{array}{l}\text { Lloreda s.a } \\
\mathbf{3 . 2 \%}\end{array}$ \\
\hline & & $\begin{array}{l}\text { Palmeras de Puerto Wilches } \\
\text { S.A. }\end{array}$ & \\
\hline & & Agroince Ltda. Y Cia. S.C.A & \\
\hline & & Palmas del Cesar S.A & \\
\hline & & Extractora Monterrey s.a. & $\begin{array}{l}\text { C. I Santandereana de Aceites s.a } \\
\mathbf{2 . 7 \%}\end{array}$ \\
\hline BioD s.a. & $10.4 \%$ & $\begin{array}{l}15 \text { palm oil } \\
\text { producers/growers }\end{array}$ & $\begin{array}{l}\text { Some are vertically integrated } \\
\text { with processors. }\end{array}$ \\
\hline \multirow{2}{*}{$\begin{array}{l}\text { Odin Energy } \\
\text { (established in } \\
\text { February 2009. Out } \\
\text { of operation since } \\
\text { January 2012) } \\
\end{array}$} & $0 \%$ (in liquidation) & $\begin{array}{l}\text { N.A. (Japanese investors non } \\
\text { - palm oil producers) }\end{array}$ & \\
\hline & Total: $39.5 \%$ & & Total: $\mathbf{2 0 . 5 \%}$ \\
\hline
\end{tabular}

Source: own construction on the basis of Fedebiocombustibles, 2011; Fedepalma, 2011a, Mesa Dishington, 2009; Observatorio Agrocadenas, 2006, Oleaginosas Las Brisas S.A., 2010; Revista Dinero, 2012. 
Second, Venezuela - which had been the most important destination for exports - restricted access to the market for Colombian palm oil since 2002 by imposing import tariffs and import licenses (Mesa Dishington, 2009: 104). Therefore, palm oil producers had to look for other markets for the palm oil originally destined to the Venezuelan market as well as for the increased volume of palm oil output.

Third, the EU became an attractive market due to:

i) an increasing demand for vegetables oils resulting from the EU increase in biodiesel demand and production driven by the EU Biofuels Directive (EC, 2003), and

ii) a privileged access to the EU market for palm oil imports from Colombia through preferential imports duties granted under the EU's 'Generalised Scheme of Preferences'.11

Fig. 3.6. Colombian palm oil exports per regions of destination 2000-2010

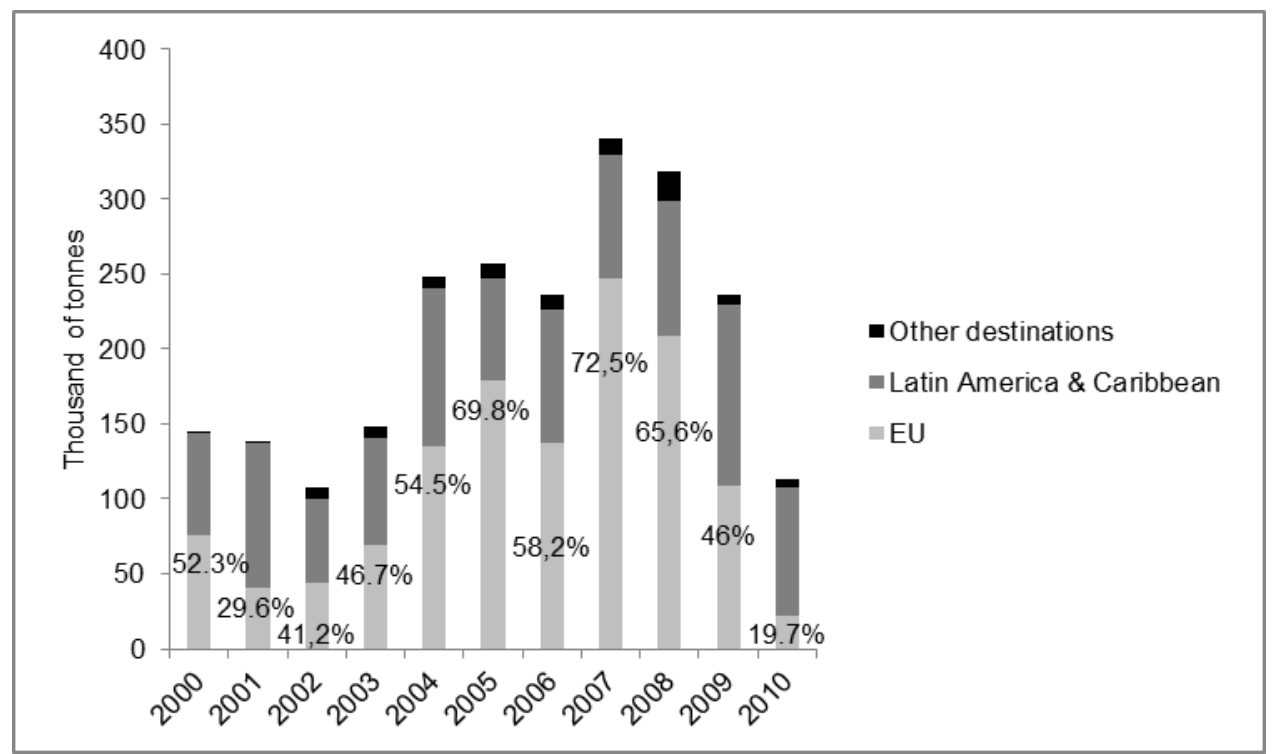

Source: own construction on the basis of data extracted from SISPA (Statistics Information System of the Palm Oil Sector).

\footnotetext{
11 The EU's 'Generalised Scheme of Preferences' is an unilateral system of trade preferences that allows certain developing country exporters to pay lower duties on their exports to the EU to facilitate their access to EU markets and contributes to their economic growth. (http://ec.europa.eu/trade/policy/countries-and-regions/development/generalised-scheme-ofpreferences/index_en.htm, Accessed August 23, 2013).
} 
Fig. 3.7. National and international crude palm oil prices 2000-2010

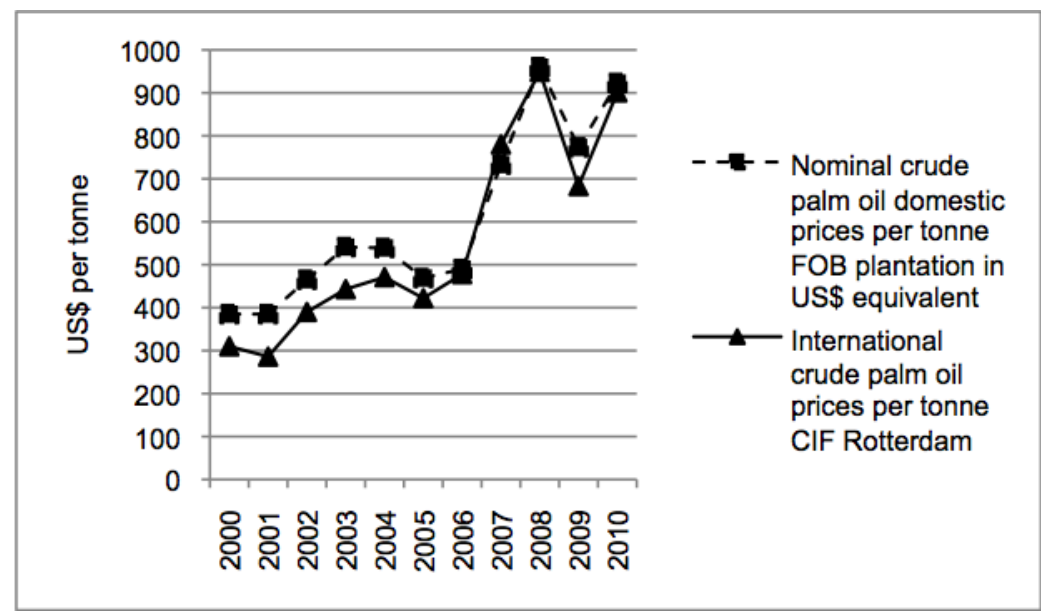

Source: Fedepalma, 2005, 2009, 2011a.

The increase in exports from Colombia to the EU coincided with a trend of increasing consumption of vegetable oils in the EU, which has been attributed to the increasing biofuel production driven by the EU policies for the promotion of the use of biofuels. Since 2003, when the EU Biofuels Directive (EC, 2003) was adopted, the EU has aimed at increasing the share of biofuels in overall EU consumption of fuels for transport (EC, 2003 and 2009). The 2003 Biofuels Directive established indicative targets of $2 \%$ and 5,75\% to be reached by 2005 and 2010 respectively. Although these targets were not achieved, the overall volume production of biofuels in the EU started to grow quickly since 2003, in particular biodiesel production, the most widely used biofuel in the EU. ${ }^{12}$ The policy-driven increase in biodiesel production coincides with increasing consumption of vegetable oils, especially rapeseed oil and palm oil as shown in Fig. 3.8.

As palm oil is not produced in the EU, all the consumption comes from imports. Some analysts consider that the increase in EU palm oil imports since 2003 is explained by imports to substitute for rapeseed oil diverted from the food market to biodiesel production (Edwards et al., 2008; Malins, 2013; Thoenes, 2007;). These imports are defined by Edwards et al. (2008) as 'indirect imports', i.e. imports of substitutes for feedstock diverted from other uses to biofuel production.

${ }^{12}$ Biodiesel represented about $78.5 \%$ of the biofuels used in the EU in 2008 and $75 \%$ in 2010 (EurObserv'ER, 2009; Ecofys et al., 2012). 
Fig. 3.8. EU biodiesel production, vegetable oils consumption and palm oil imports 20002010

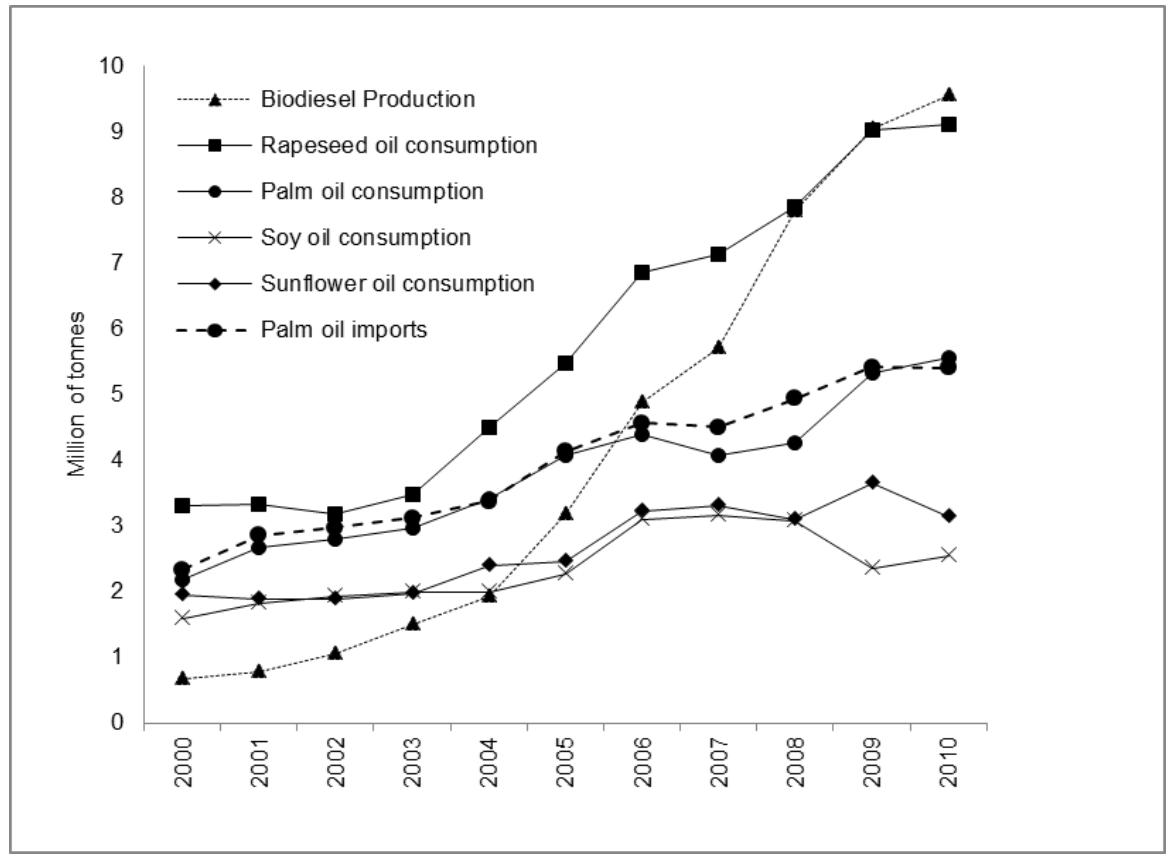

Source: EurOberv'ER, 2004, 2005, 2006, 2007, 2008, 2009, 2010, 2011 and Fediol, $2013 \mathrm{a}$. Note: The slowdown in growth rates of vegetable oil consumption in 2007 and 2008 is associated with a slowdown in biodiesel production resulting from the increase in imports of this biofuel from the US (EurObservER, 2008 and 2009).

The data on the composition of feedstock used for EU biodiesel production per Member State are "kept confidential because the information is competition sensitive" (Ecofys et al., 2012). However, the European Commission and some studies report that most of the EU palm oil imports and consumption during the 2003-2010 period were not directly used for biodiesel production. ${ }^{13}$ Indeed, most of the EU biodiesel is produced from rapeseed oil as the EU is amongst the world's leading rapeseed producers (Fediol, 2013b; 2012; MVO,

\footnotetext{
13 The European Commission released a memorandum in 2010 stating that "only about $4-5 \%$ of biofuel in the EU was produced from palm oil" (EC, 2010). Other sources reported that the share of palm oil in the total vegetable oils used for biodiesel production in the EU from 2006 to 2009 ranged between 5.5\% and 7,5\% (MVO, 2009). However, a report from 2013 indicates that the share of palm oil in the feedstock mix for biodiesel produced in Europe increased from 8\% in 2006 to $20 \%$ in 2012 (Gerasimchuk and Koh, 2013).
} 
2008 and 2009). ${ }^{14}$ The predominance of rapeseed oil in the feedstock mix for biodiesel production in the EU is further confirmed by:

i) the similar trends between biodiesel production and rapeseed consumption in Fig. 3.8 , and

ii) the fact that since 2004 rapeseed oil consumption for industrial purposes exceeded consumption for edible purposes (Fig. 3.9).

Yet the fact that rapeseed oil consumption for edible uses remained stable at around 2.8 million tonnes since 2000 (see Fig. 3.9), supports the argument of the substitution of palm oil for rapeseed oil, which in turn can explain palm oil 'indirect imports'.

Fig. 3.9. Rapeseed oil consumption for food and industrial use in the EU 2000-2010

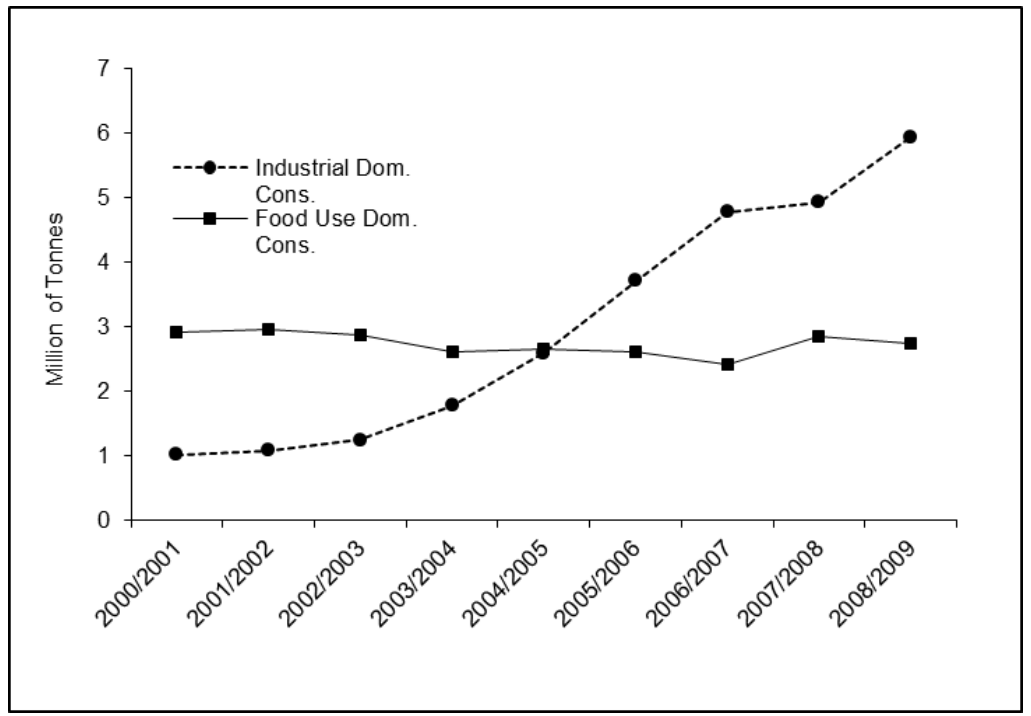

Source: Source: FAS-USDA estimates, 2010.

'Indirect imports' demonstrate that the flex-crop nature of palm oil is not only represented by its inter-changeable multiple uses (Borras et al., 2012), but also by its perfect exchangeability with other vegetable oils such as rapeseed oil, soy oil and sunflower oil (Schmidt and Weidema, 2008). A consequence of the exchangeability among these different vegetable oils is that their markets are intertwined so that international prices of any of these commodities may affect the demand, supply and prices of the others. Thus, the

\footnotetext{
${ }^{14}$ Some reports indicate for example that rapeseed oil was the major feedstock for the EU's biodiesel production in 2008/2009 with a share of $70 \%$ (MVO, 2009).
} 
higher EU consumption of palm oil compared to the other substitutes of rapeseed oil (Fig. 3.8) can be further explained by the relative lower international prices of palm oil compared to the prices of soy oil and sunflower oil. Palm oil has been the most price competitive vegetable oil since 1999 (Abdullah, 2011; Schmidt and Weidema, 2008; MVO, 2010).

Due to data access limitations it was not possible to establish the use of palm oil imported from Colombia once it enters into the EU. However, the distribution of the exports among the different EU destinations between 2004 and 2008 indicates that Colombian palm oil exports to the European Union were related at least partially with the increasing EU biodiesel production, i.e. they were direct or indirect biofuel feedstock imports. The volume of palm oil exported to the EU until 2003 had been mainly directed to the United Kingdom (UK) and The Netherlands. However, Fig 3.10 shows that since 2004 new export destinations within the EU included Member States that were increasing biodiesel production rapidly, i.e. Germany and Spain.

Fig. 3.10. Colombian palm oil exports to EU per major markets of destination 2000-2009

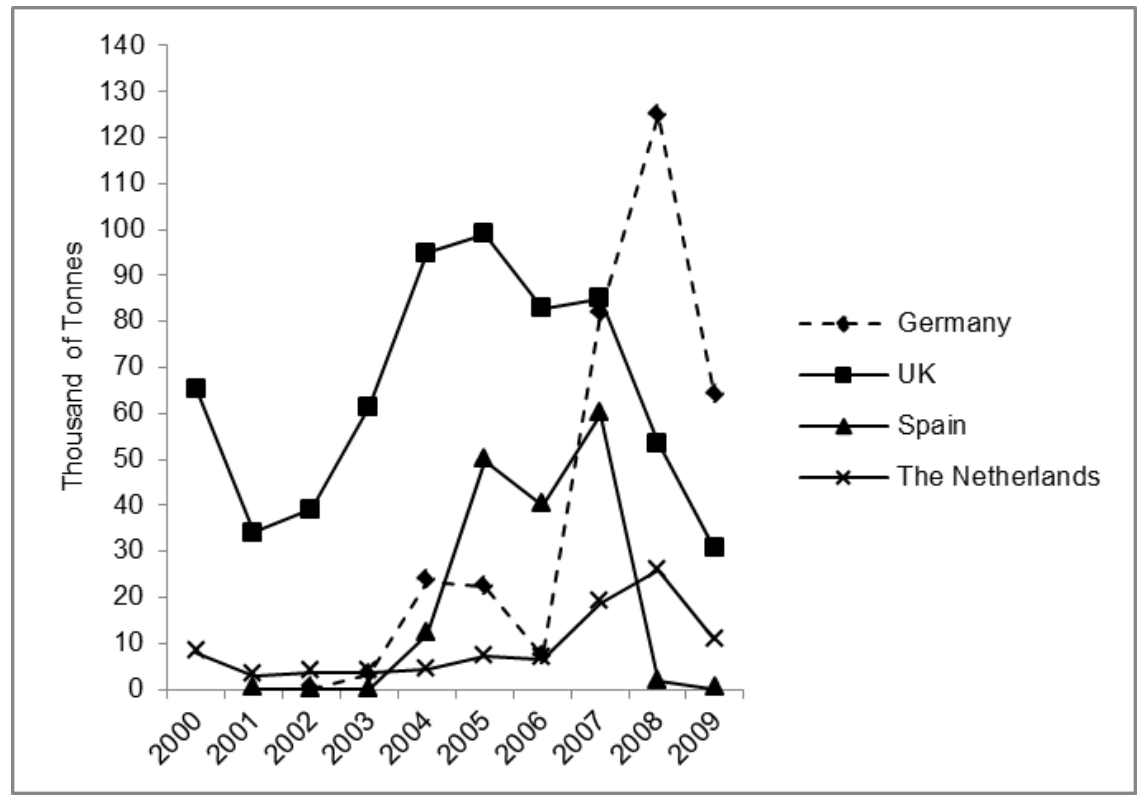

Source: own construction on the basis of data extracted from SISPA (Statistics Information System of the Palm Oil Sector).

Germany is the EU's main producer of biodiesel. It accounted for about $50 \%$ of the EU's biodiesel production between 2000 and 2008, while Spain started to increase its biodiesel production rapidly since 2005 passing from 13 million tonnes in 2004 to 207 million tonnes 
in 2008. Moreover, the volume of palm oil exported to the UK had a remarkable increase since 2004, coinciding with the substantial increase in its biodiesel production from 9 million tonnes in 2004 to 192 million tonnes in 2008 (EurObserv'ER, 2004, 2005, 2006, 2007, 2008, 2009).

Palm oil's versatility made it possible for palm oil producers to grasp the opportunities derived from a global biofuel boom in international markets, especially the EU 'indirect imports' of palm oil. However, as the multiple and flexible uses of palm oil allows a diversified product portfolio (Borras et al., 2012) palm oil producers can allocate sales to different markets according to their profitability. This is illustrated by the shift in the Colombian palm oil exports towards the Mexican market as trade preferences negotiated between Mexico and Colombia in 2009 granted free access to palm oil imports from Colombia, and the logistic costs of exporting to Mexico are lower than the costs of exporting to Europe. While the share of exports to the EU was reduced to less than $20 \%$ of the total exports in 2010, the share of exports to Mexico increased representing about 22\% and 30\% of the total exports in 2009 and 2010, respectively (Fedepalma, 2010a and 2011a). This change is reflected in the increase in the share of exports to Latin America and the Caribbean in 2009 and 2010 (Fig. 3.6).

3.4.2. The 'space-of-place': oil palm 'crop boom' and trajectories of land control and resistance

The contemporary expansion of the palm oil frontier in the 'space-of-flows' took the form of a 'crop boom' in the 'space-of-place' (see Section 3.2 for the definition of 'crop boom'). Although the land devoted to oil palm cultivation has expanded continuously in Colombia since oil palm cultivation started to consolidate in the 1960s, the largest rise in cultivation started in 2002 (see Fig. 3.2 in Section 3.3). The amount of land cultivated with oil palm almost tripled between 2000 and 2010, from 157,000 hectares in 2000 to 404,000 hectares in 2010 (Fedepalma, 2005 and 2011a).

The geography of this expansion was determined by oil palm cultivation/palm oil production physical requirements and the way in which production is organized. However, this geography overlaps with the geography of an agrarian history of violence and land concentration that shaped country-specific trajectories of expansion involving land control practices of 'accumulation by dispossession' and 'assimilation'.

Oil palm cultivation and palm oil production in Colombia are organized in what the agroindustry calls 'palm oil nuclei'. A palm oil nucleus is made of an extraction plant and its supply base (oil palm plantations that supply it with oil palm fresh fruit bunches - FFB). The potential size of the supply base of a palm oil nucleus depends on the installed 
processing capacity of the plant (tonnes of FFB per hour) and the cultivation productivity (tonnes of FFB harvested per hectare). The larger the processing capacity and lower the productivity, the larger the supply base.

The locations of the palm oil nuclei and the sites of expansion of cultivation - i.e. the 'space-of-place' of the palm oil frontier - as well as the form such expansion takes, are determined by two types of requirements of the crop.

First, palm oil has to be extracted from the FFB within twelve hours following the harvest to ensure the quality of the oil (Cenipalma and Fedepalma, 2009). Therefore, palm oil extraction plants and oil palm plantations that supply them need to be located close to each other (Cenipalma and Fedepalma, 2009). As a consequence, the expansion of cultivation necessarily takes place around palm oil extraction plants forming enclaves.

Second, the oil palm requires certain edapho-climatic conditions to grow - i.e. specific soil qualities, altitude, topography, temperature, humidity, precipitation, solar radiation and hydric balance - which determine the physical location and potential expansion of palm oil nuclei.

In the case of Colombia there are four geographical regions of oil palm cultivation and palm oil production (North, East, Central and South-west). Although the expansion of the frontier took place within these geographical limits, the vastness of the regions allowed the large expansion in hectares between 2000 and 2010. Such expansion took place, not only in the municipalities where oil palm had been traditionally grown until the end of the 1990s, but also across new municipalities, so shaping and expanding the new frontier. The number of municipalities with oil palm plantations more than doubled during the 2000-2010 period, from 47 in 1999 to 106 in 2010. New municipalities either form new enclaves or are contiguous to former municipalities of oil palm cultivation, so enlarging old enclaves. Map 3.1 illustrates these changes in the geography of the palm oil frontier between 1999 and 2010.

A particular feature of the contemporary expansion of the palm oil frontier in Colombia is that the number of extraction plants remained stable across time, in spite of the increase in cultivated area. Thus, expansion took the form of an enlargement of existing palm oil nuclei in terms of area of cultivation due to an increase of the installed capacity of existing palm oil extraction plants and their higher utilization (Mesa Dishington, 2009: 85). ${ }^{15}$

\footnotetext{
${ }^{15}$ The number of extraction plants increased only from 51 to 54 between 1999 and 2010, while the installed processing capacity increased from 748 to 1249 FFB tonnes per hour (Fedepalma 2001 and 2011a).
} 
Map 3.1. Changes in the geography of the palm oil frontier in Colombia between 1999 and 2010

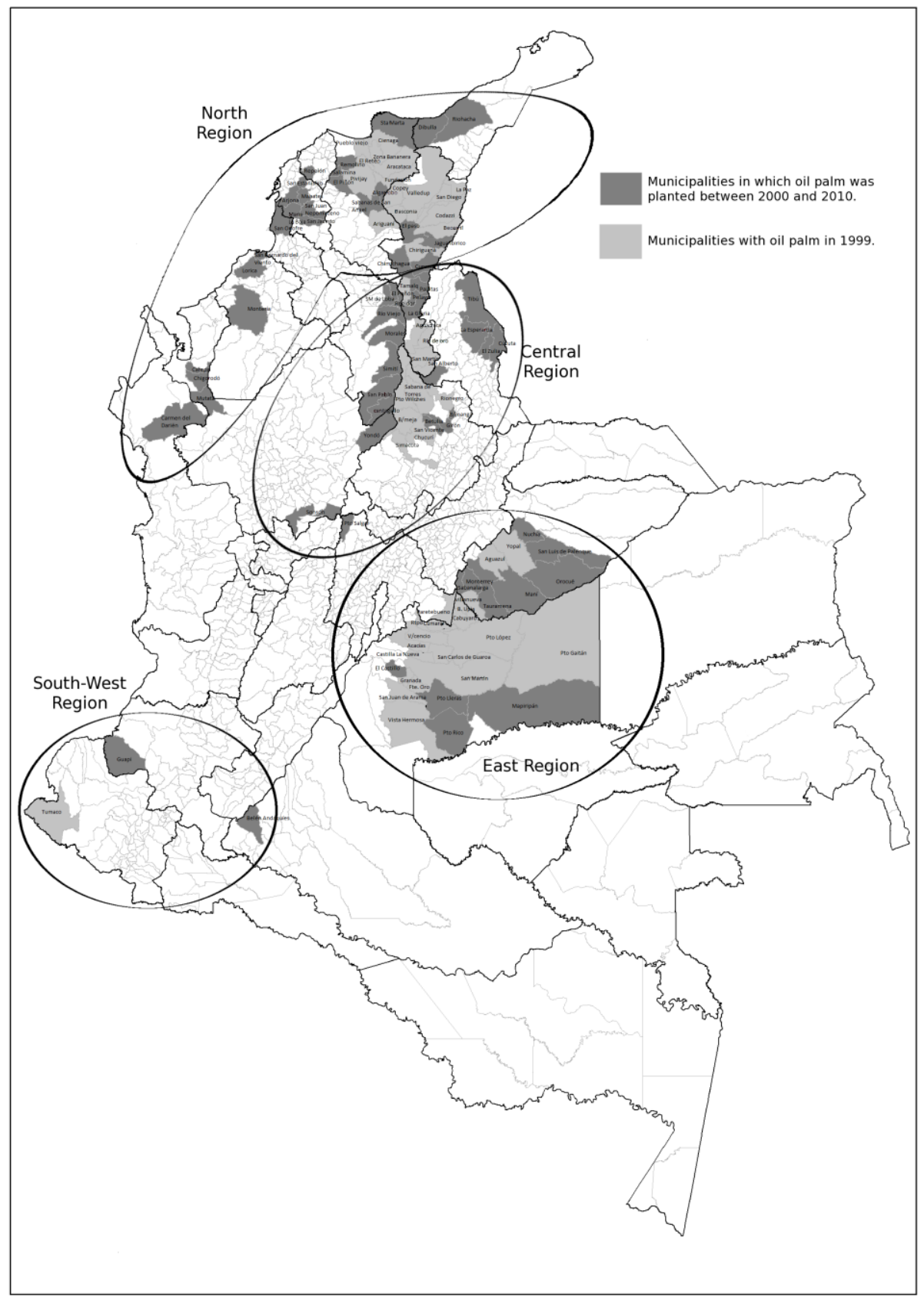

Source: own construction on the basis of Fedepalma, 2001 and 2011a. 
Although the enlargement of the palm oil nuclei indicates that the expansion of the frontier was mainly driven by former palm oil producers (hereafter I refer to these producers as established palm oil producers), new actors also entered into the business of oil palm cultivation attracted by the expected profits from the increase in demand for FFB and the governmental incentives (hereafter I refer to these producers as new comers).

The new comers included large- and medium-scale land holders, politicians, and national and local elites attracted by a new source of capital accumulation. Moreover, the group of new comers also included illegal armed groups who saw in oil palm cultivation an opportunity to legitimise the territorial control that these armed groups have gained or maintained illegally through displacement and dispossession of local people.

Both former palm oil producers/oil palm growers and new comers displayed different legal and illegal practices of land control in order to gain and control access to land for oil palm cultivation. Some of these practices took the form of either 'accumulation by dispossession' or 'assimilation' (Fig. 3.11).

The developments of the generalised internal armed conflict after the 1990s contributed to shape the land control trajectories of the contemporary expansion of the palm oil frontier in the 'space-of-place'. The rural areas in Colombia have been the theatre of a more than 50 years of agrarian conflict. The conflict is rooted in historical land concentration that originated in the colonial period between the years 1492 and 1821 (Machado, 2009), and has persisted and deepened as successive republican governments have failed to address the inequitable distribution of land and neglected peasants' claims to support their production systems. The agrarian question was the seed for the formation of guerrilla groups in the 1960s resulting in a violent country-wide armed conflict that evolved and became more complex as the agrarian issues intertwined with the incursion of the narco-economy in rural areas, the emergence of illegal paramilitary forces, the participation of both guerrilla and paramilitary groups in the narco-economy and the consequent intertwining of the armed conflict with the government's war against drugs (GMH, 2013; PNUD, 2011; Molano Bravo, 2004; Reyes Posada, 2009). ${ }^{16}$

It is in this rural setting where the contemporary expansion of oil palm cultivation - and the expansion of other extraction frontiers - is played out. Two recent processes connected with generalised armed conflict are relevant to understand the trajectories of the contemporary expansion of the palm oil frontier in the 'space-of-place'.

\footnotetext{
16 The term narco-economy is used in this thesis to refer to the cultivation, processing and commercialisation of crops considered illicit under the Colombian law (marijuana, coca and opium poppy) and the products derived from processing such crops (for example, cocaine paste, cocaine base, cocaine, opium poppy latex, heroine).
} 
Fig. 3.11. Characterization of land control practices of 'accumulation by dispossession' and 'assimilation' connected with the 2000-2010 expansion of the palm oil frontier in Colombia

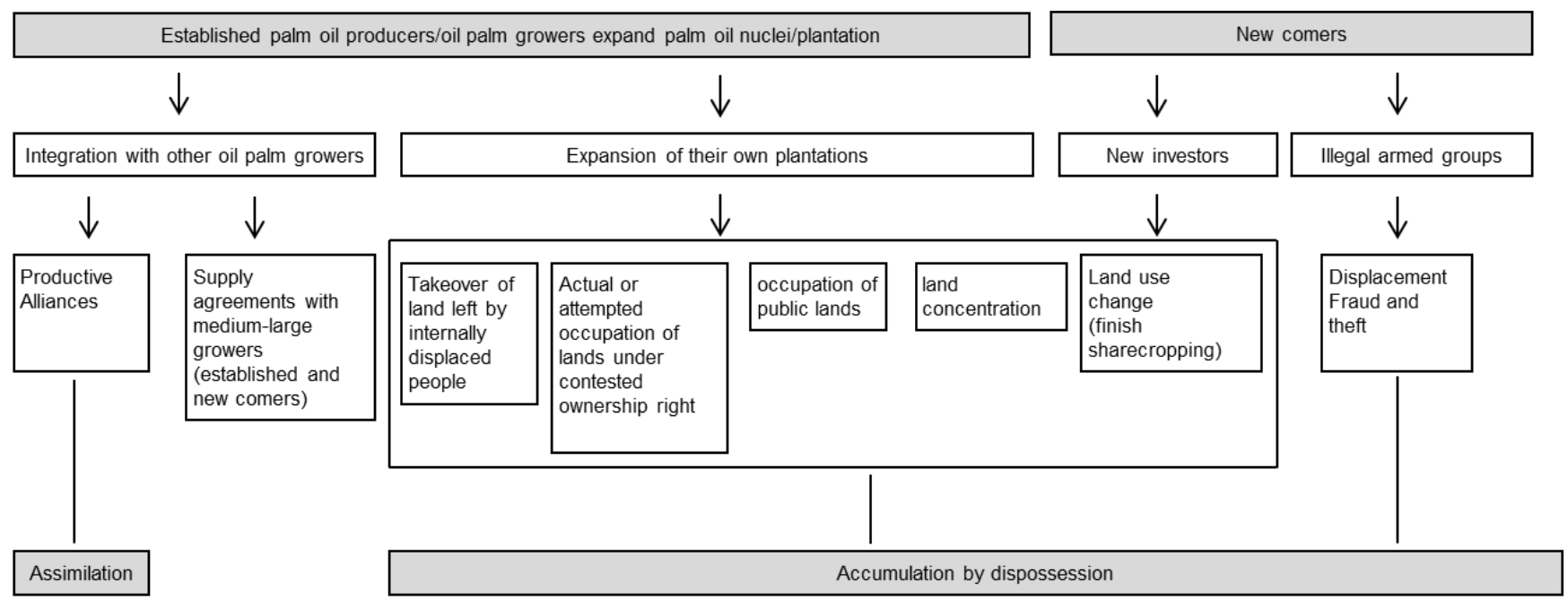

Source: own construction. 
First, the promotion of agricultural productive activities as alternatives to illegal crops cultivation through financial support to contract farming schemes called 'productive alliances'. ${ }^{17}$ This strategy substantially funded the establishment of 'productive alliances' for the expansion of oil palm cultivation (see Section 3.4.2.1 for the definition and details about 'productive alliances').

Second, the widespread internal displacement of people in rural areas, especially between 1997 and 2005, that resulted from the generalised armed conflict (GMH, 2013). ${ }^{18}$ Displacement entailed a process of "emptying rural territories" not only from their inhabitants but also from the land uses attached to rural dwellers' livelihoods (GMH, 2013; Ibáñez and Moya, 2010; PNUD, 2011). ${ }^{19}$ This process paved the way for land control practices that took the form of 'accumulation by dispossession', and created a proper setting for the promotion and establishment of oil palm 'productive alliances', as explained in Sections 3.4.2.1 and 3.4.2.2 below.

Map 3.2 combines the geography of displacement between 1998 and 2006 with the geography of the palm oil frontier identifying the location of both areas cultivated with oil palm under 'productive alliances' and areas where cases of 'accumulation by dispossession' have taken place. Map 3.2 shows that almost all the municipalities in the palm oil frontier registered high or medium levels of displacement, and all the cases of 'accumulation by dispossession' identified in Section 3.4.2.2, except one, have taken place in municipalities affected by high levels of displacement. ${ }^{20}$ Moreover, oil palm cultivation under "productive alliances' takes place in more than half of the municipalities of the palm oil frontier.

\footnotetext{
${ }^{17}$ See Grossman, 1998 for details on contract farming from the perspective of political ecology.

${ }^{18}$ A recent report on the historical armed conflict reveals that the number of internally displaced people amounts to about 5,700,000 (GMH, 2013). Colombia is the country with the largest number of internally displaced people in the world.

19 The term "emptying territories" ("vaciando territorios" in Spanish) was borrowed from Vélez, 2008.

${ }^{20}$ Municipalities with high levels of displacement mean municipalities that registered a rate of displacement more than 5,000 displaced people per 100,000 inhabitants (i.e. a high rate of displacement) in one or more years during the period 1998-2006. Municipalities with medium levels of displacement mean municipalities that do not registered a high rate of displacement in any year of the 1998-2006 period, but registered a rate of displacement between 1,000 and 5,000 displaced people per 100,000 inhabitants (i.e. a medium rate of displacement) in one or more years during the same period. Municipalities with low levels of displacement mean municipalities that registered neither high nor medium rates of displacement in any year of the 1998-2006 period, but registered a rate of displacement less than 1,000 displaced people per 100,000 inhabitants (i.e. a low rate of displacement) in one or more years during the same period.
} 


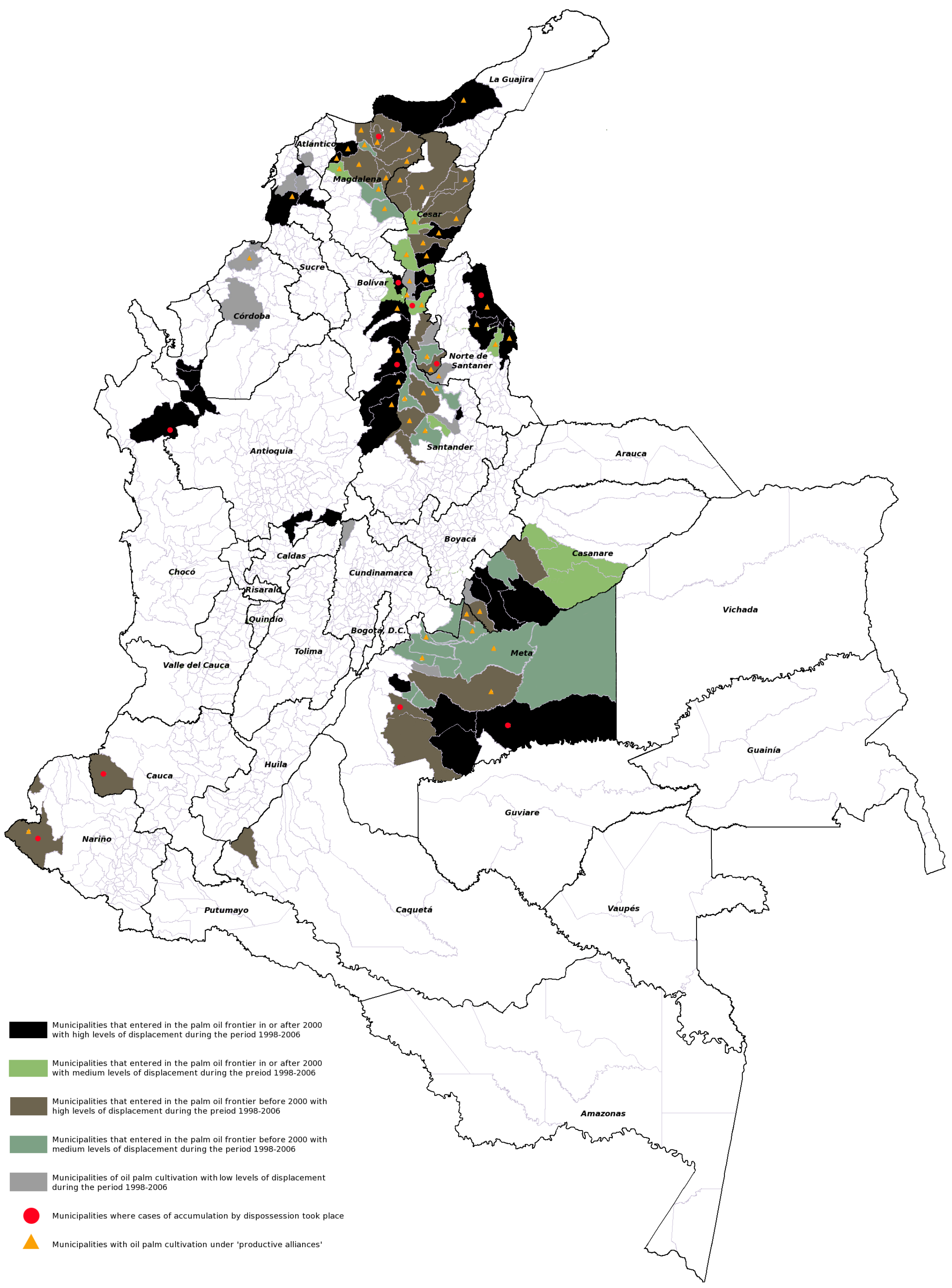

Source: own construction.

Note: the sources of data about displacement rates per municipality during the 1998-2006 period are Reyes Posada et al., 2009 and Reyes Posada et al., 2010. Data about the palm oil geography come from Fedepalma, 2001 and 2011a. Data about 'productive alliances' come from USAID, 2010; Cecodes, 2010. See Appendix B - Table B.1 for data sources of cases of 'accumulation by dispossession'. 


\subsubsection{Land control, 'productive alliances' and 'assimilation':}

Established palm oil producers resorted to different strategies to enlarge the palm nuclei under their control. Integration of palm oil production with oil palm growing through contract farming arrangements labelled as 'productive alliances' was characteristic of the enlargement of palm oil nuclei in the new frontiers. 'Productive alliances' are a business model to integrate associations of small- and medium-scale land holders (supply allies) into the supply base of a palm oil extraction company (anchor company). ${ }^{21}$

The first 500 hectares of oil palm cultivated under a 'productive alliance' scheme were planted in 1999. They were part of a project to plant 5,000 hectares using 'productive alliances' in which the anchor organization was one of the companies of the Oleoflores business group owned by the former Minister of Agriculture Carlos Murgas (Vidal Tovar and Villarroel, 2011). By 2010, there were 109 associations grouping about 5,000 growers throughout the palm oil geography (Mesa Dishington, 2011). This form of integration spread so extensively that oil palm cultivation under 'productive alliances' had taken place across more than half of the municipalities of the palm oil frontier by 2010 (see Map 3.2). About 25\% (about 61,000 hectares) of the new hectares cultivated with oil palm between 2000 and 2010 were under the form of 'productive alliances' (Mesa Dishington, 2011).

Two types of support were key to the expansion of the palm oil frontier through the incorporation of small holding growers into oil palm cultivation and the formation of 'productive alliances' during the 2000-2010 period.

First, governmental support through subsidies and agricultural credit for oil palm growers engaged in 'productive alliances' as explained in detail in Chapter 4. This support initiated with a programme to promote 'productive alliances' in different agricultural sub-sectors proposed by Carlos Murgas while he was Minister of Agriculture (1998-1999). Since the rural areas constituted the setting where there was armed conflict, 'productive alliances' were framed as a mechanism that would contribute to peace and development. Indeed, the programme was called "Productive and Social Alliances for Sowing Peace" (Murgas, 1999).

\footnotetext{
21 The 'productive alliances' are defined by Fedepalma as "a set of relationships and formal arrangements between producers of agricultural goods, traders, agro-industries, and public or private support organizations, the purpose of which is to expand the area of agro-industrial cultivation of latematuring crops and modernise technologically the productive units of small-scale growers." (Cecodes, 2010: 3).

Orignal in Spanish: "son un conjunto de relaciones y arreglos formales entre productores de bienes agropecuarios, comercializadores y agroindustriales y organismos de apoyo, públicos o privados, cuyo propósito es expandir empresarialmente las áreas de cultivos de tardío rendimiento y actualizar tecnológicamente a las unidades productivas de pequeños productores."
} 
Second, the allocation of a portion of the United States' funding for the war against drugs in Colombia to finance 'alternative development' projects was also an important factor facilitating the expansion of the frontier through 'productive alliances'. Illicit crops controlled by both narco-barons and illegal armed groups (guerrilla and paramilitary groups) irrupted in rural areas since the 1970s. Peasants became involved in the cultivation and harvesting of illicit crops since these activities appeared as livelihood opportunities in a context of lack of both public infrastructure and state presence that hindered peasants' ability to live out of their traditional modes of production (Dion and Russler, 2008; Ibanez, 2010; Molano Bravo, 2004; Ortíz, 2004).

The governmental war against drugs included eradication campaigns along with strategies framed as 'alternative development' to remove rural people from, or prevent them from entering into, illicit crop cultivation by providing support for other productive activities (Vargas Meza, 2010). Since 2000, the United States started to support the Colombian government's alternative development strategies by allocating funds from the war against drugs to promote alternative productive projects through the United States Agency for International Development (USAID) office in Colombia (Guáqueta, 2005; Vargas Meza, 2010). The USAID 'alternative development' programme included oil palm among the products the cultivation of which was prioritised for funding. The other products were cacao, coffee, rubber, and commercial forestry plantations (CONPES, 2003; Vargas Meza, 2010). Oil palm projects started to be supported from 2001. By the end of 2009, USAID had supported 24 projects that covered about 52,000 hectares of oil palm in 57 municipalities and involved small-scale grower schemes operated by fifteen anchor organizations (USAID, 2010). This represented about $25 \%$ of the hectares planted between 2000 and 2009.

The establishment of 'productive alliances' and the governmental and USAID's support to these contract farming schemes opened up new avenues for established palm oil producers to expand the palm oil frontier in municipalities hardly affected by the generalised internal conflict. Indeed, most of the hectares cultivated under 'productive alliances' are:

i) located in municipalities that show high and medium levels of displacement (Map 3.2), and

ii) controlled by established palm oil producers belonging to business groups owned by wealthy families that have been historically involved in the business of palm oil production (Table 3.3) 
The threats and attacks of guerrilla groups against members of the palm oil agro-industry (Rangel et al., 2009 and Mesa Dishington, 2009) and the insecurity in land tenure derived from the land grabbing that followed displacement became a deterrent for established palm oil producers to expand their own plantations during the 1990s. Moreover, the measures established in the Colombian law to protect the lands and territories of local people in areas of displacement or under risk of displacement also constrained land acquisition by established palm oil producers/oil palm growers. The reason is because lands and territories declared under protection cannot be negotiated. ${ }^{22}$ Since many municipalities in the new frontiers of oil palm cultivation have been declared under protection (SNR, 2013), established palm producers/oil palm growers could not acquire land to expand their plantations.

However, palm producers/oil palm growers could enter into 'productive alliances' with local land holders. Some examples are the municipalities of Tibú and Regidor in the Central Region of the palm oil geography. The entire rural areas of Tibú and Regidor are under protection measures since 2002 and 2006, respectively (SNR, 2013). The expansion of oil palm cultivation in these two municipalities has taken place mainly through 'productive alliances' controlled by established palm oil producers/oil palm growers. In Regidor the oil palm growing companies Agroindustrias San Lucas, Macías, Tumaco and Hacienda Puerto Libre started to establish 'productive alliances' to expand the palm oil frontier since 2006 i.e. when the protection measures were adopted - (El Tiempo, 2007). In Tibú, the palm oil business group Oleoflores started to establish 'productive alliances' since 2003 - after the protection measures were adopted - (Cecodes, 2010). By 2010, there were about 12,000 hectares of oil palm under 'productive alliances' controlled by Oleoflores in Tibú (USAID, 2010).

Integrating palm oil production with oil palm growing through 'productive alliances' provides palm oil producers with land access control through the conditions of the agreement with the supply allies. Under the 'productive alliances' model the supply allies commit to devote land and labour to grow oil palm and to supply FFB to the anchor company, while the latter commits to buy the FFB from the allies. In most cases, the supply allies take loans to cover costs of the plantation establishment (see Table 3.3). The cost of buying land is also financed through loans in some cases (Cecodes, 2010).

${ }^{22}$ Law 387, 1997 and Decree 2007, 2001. 
Table 3.3. Large-scale palm oil producers controlling most of the oil palm cultivation under 'productive alliances' in 2010

\begin{tabular}{|c|c|c|c|c|}
\hline \multirow[t]{3}{*}{$\begin{array}{c}\text { Anchor company } \\
\text { business/ family froup }\end{array}$} & \multicolumn{4}{|c|}{$\begin{array}{l}\text { Oil palm cultivation under control of large-scale palm oil producers through } \\
\text { 'productive alliances' in } 2010\end{array}$} \\
\hline & \multirow{2}{*}{$\begin{array}{l}\text { Number of supply } \\
\text { allies (associations } \\
\text { of small-scale } \\
\text { growers) }\end{array}$} & \multirow[t]{2}{*}{ Hectares } & \multicolumn{2}{|c|}{$\begin{array}{l}\text { Funding for 'productive } \\
\text { alliances' }\end{array}$} \\
\hline & & & Credit & $\begin{array}{l}\text { USAID } \\
\text { funding }\end{array}$ \\
\hline $\begin{array}{l}\text { Oleoflores business group } \\
\text { (Murgas Dávila Family) }\end{array}$ & 35 & $25,000($ Sept 30, 2011) & $\checkmark$ & $\checkmark$ \\
\hline $\begin{array}{l}\text { Indupalma } \\
\text { (Haime Gutt Family) }\end{array}$ & 5 & 6,800 & $\checkmark$ & $\checkmark$ \\
\hline $\begin{array}{l}\text { C.I Tequendama - } \\
\text { DAABON business group } \\
\text { (Dávila Abondano Family) }\end{array}$ & 7 & 3,185 & $\checkmark$ & $\checkmark$ \\
\hline $\begin{array}{l}\text { C.I El Roble } \\
\text { (Lacouture Pinedo Family) }\end{array}$ & 6 & 3,400 & $\checkmark$ & $\checkmark$ \\
\hline $\begin{array}{l}\text { Extractora Frupalma s.a. } \\
\text { (Vives Lacouture Family) }\end{array}$ & 11 & 3,400 & $\checkmark$ & $\checkmark$ \\
\hline Total & 64 & $\begin{array}{l}41,785 \text { (about } 67 \% \text { of the } \\
\text { hectares planted under } \\
\text { productive alliances } \\
\text { between } 2000 \text { and } 2010 \text { ). }\end{array}$ & $\checkmark$ & $\checkmark$ \\
\hline
\end{tabular}

Source: own construction based on Barragán, 2010; Indupalma, 2010; Pérez Castro, 2012; SGS, 2010; Oleoflores website ${ }^{23}$; USAID, 2010.

The anchor company controls the plantations through the conditions of the alliance agreement. Typically, the agreement involves a long-term exclusive supply commitment on the part of the growers. The term is usually equivalent to the commercial lifetime of a plantation, i.e. 25-30 years. Moreover, supply allies also commit to follow the recommendations of the anchor company in terms of technical management of the plantation and administrative management of the association in order to ensure the quality of the raw material and the efficiency of the business (Cecodes, 2010). Usually, the palms, the technical support and the extension services provided by the anchor company must be paid for by the supply allies to the anchor company.

The idea of people committing their lands and labour to produce in a tied contract for the palm oil producer, having to pay with the related "income" its own salary, the capital and interests of the credit obtained to finance in some cases the land and in all cases the costs of planting the oil palm, plus the extension services and materials to the palm oil company, "is a remarkable construction to justify the process of land control" (White and Dasgupta, 2010: 602).

\footnotetext{
${ }^{23}$ http://www.oleoflores.com/alianzas.html\#content12 (Accessed March 11, 2014).
} 
The operation of a 'productive alliance' under the conditions detailed above requires participants to adopt the business mindset necessary for managing a commodity plantation. Thus, this form of land control may entail 'assimilation' as it denies and erases the cultural and identity practices that differentiate peasant agriculture from capitalist agro-industries as explained in Chapters 4,5 and 6. The vulnerability of peasants subject to historical marginalization and violence derived from the generalised armed conflict made them easy targets for 'assimilation' processes through incorporation in 'productive alliances'.

However, not all the supply allies retain a peasant tradition, as the supply allies are not a homogeneous group. Although there has not been a demographic characterization of the members of the associations engaged in 'productive alliances', data from fieldwork interviews as part of this thesis and secondary sources indicate that their membership configuration is varied and complex.

On the one hand, there are supply allies who have already been involved in the cultivation of crops that entail the type of profit-oriented mentality required to participate in oil palm 'productive alliances'. For example, some members of 'productive alliances' have worked in oil palm plantations. These small-scale growers have the experience and knowledge of oil palm cultivation and see participation in the commodity chain as a positive livelihood opportunity (fieldwork interviews; Reales Castilla, 2009).

There are also small-scale growers who were previously involved in illicit crops cultivation. Government financial support for oil palm cultivation makes this a profitable alternative crop and also offers farmers to don the cloak of legitimacy. For example, in a group meeting held during fieldwork for this thesis a small-scale oil palm grower mentioned his previous involvement in coca cultivation and expressed his willingness to grow any crop that promises to be profitable. He explained that he enrolled in oil palm cultivation as a substitute for illicit crops activities because that was the crop being financially supported at the moment and it was profitable. However, he was also trying to start rubber cultivation for the same reasons.

Some case studies have even found that not all small holdings registered as part of 'productive alliances' belong to local farmers, but to people from nearby towns or landowners that entered into oil palm cultivation to extract rents from the land (Pérez Castro, 2012; Reales Castilla, 2009).

On the other hand, farmers that come from a peasant tradition are also members of smallscale oil palm growers associations despite their agricultural practices being at odds with the business mindset required to manage an oil palm plantation (fieldwork interviews; Gómez López, 2010; Pérez Castro, 2012). The explanation for this apparent contradiction 
comes from a lack of alternatives derived from a historical process of marginalization that peasants have been subject to, i.e. "the process by which they lose the ability to control their own lives (where they live and derive their income, what crops or stock they produce, how hard and when they work)" (Blaikie, 1985: 125).

Such marginalization is rooted in the same conditions that led some peasants to get involved in illicit drug cultivation (Ibanez, 2010). Marginalization has been furthered by the displacement and the destruction of the socio-economic base of rural territories resulting from the generalised armed conflict (Ibáñez and Moya, 2010).

In such a context of marginalization, the government and agro-industry have presented 'productive alliances' as an inclusive business model of oil palm cultivation with potential to bring peace and development to rural areas (Murgas, 1999).

Therefore, for those who had been displaced and marginalised this incorporation scheme emerged as "the" option to be able to gain or maintain access to land and to ensure subsistence food production and income for their families. This is illustrated by the following quote from a member of an association engaged in an oil palm 'productive alliance' in the North Region of the palm oil geography: "The best lands are being cultivated with palm, there are no more offers for the peasant, that is why palm continues to expand" (small-scale oil palm grower member of ASOPALMAG quoted in Pérez Castro, 2012: 22$)^{24}$

This is also the situation of internally displaced peasants who were assigned land by the government subject to the obligation of establishing oil palm plantations (fieldwork interviews; Herrera, 2008), such as the members of ASOBENPRO (Asociación de Beneficiarios del Proyecto de Palma el Progreso). During a group meeting with members of ASOBENPRO (during fieldwork for this thesis), they explained that, although they came from the peasant tradition, they accepted to grow oil palm because given the terms imposed by the government for assigning them land, it was the only way to gain access to land and a means of a livelihood (see Case 3 in Chapter 5).

Thus, in such cases in which peasant incorporation is constrained by their marginalization, 'productive alliances' constitute mechanisms of land control that entail clear forms of 'assimilation'. Moreover, such form of inclusion may unfold as 'adverse incorporation' when peasants are engaged under disadvantageous terms as their situation of marginalization limits their ability to negotiate fair conditions (Hickey and du Toit, 2007).

\footnotetext{
${ }^{24}$ Original in Spanish: "las mejores tierras se están cultivando de palma, no hay más ofertas para el campesino por eso se sigue expandiendo la palma".
} 
The extent of oil palm cultivation under 'productive alliances' between 2000 and 2010 indicates that palm oil producers may have gained land access control for the contemporary expansion of the frontier through the practice of 'assimilation'. However, the large number of associations engaged in oil palm 'productive alliances' and their varied and complex membership configuration call for further research for a more nuanced understanding of 'assimilation' and 'adverse incorporation' processes.

3.4.2.2. Land control, 'accumulation by dispossession' and socio-environmental conflicts:

Besides 'productive alliances', the expansion of the palm oil frontier in the 'space-of-place' encompasses a more varied set of land control practices deployed, not only by palm oil producers, but also by independent oil palm growers, new investors and even illegal paramilitary groups. Established palm oil producers sought, not only to expand their own plantations, but also to integrate former and new independent growers through supply arrangements into the palm oil nuclei.

The palm oil industry's increasing demand for FFB and the strong governmental support to promote cultivation (see Chapter 4) motivated former oil palm growers to plant more oil palm, and attracted new comers seeking capital accumulation or territorial control through oil palm cultivation. The new comers were a heterogeneous group of businessmen and landholders looking for more profitable uses for their plots (called new investors in Table 3.4), as well as illegal paramilitary groups.

The array of land control practices displayed to expand oil palm cultivation ranges from legal acquisition to theft, fraud and violent displacement. Some of these practices represent forms of 'accumulation by dispossession' as illustrated by the cases presented in Table 3.4.

The violent displacement by illegal paramilitary groups followed by oil palm cultivation to legitimate/retain territorial control and accumulate economic rents using the facade of a legal agri-business (Cases 1, 2 and 10 in Table 3.4) is the most striking type of 'accumulation by dispossession' connected with oil palm cultivation. It has also received most of the attention from media, academia, civil society organizations, international organizations and state agencies. 
Table 3.4. Cases of 'accumulation by dispossession' connected with the 2000-2010 expansion of the palm oil frontier in Colombia

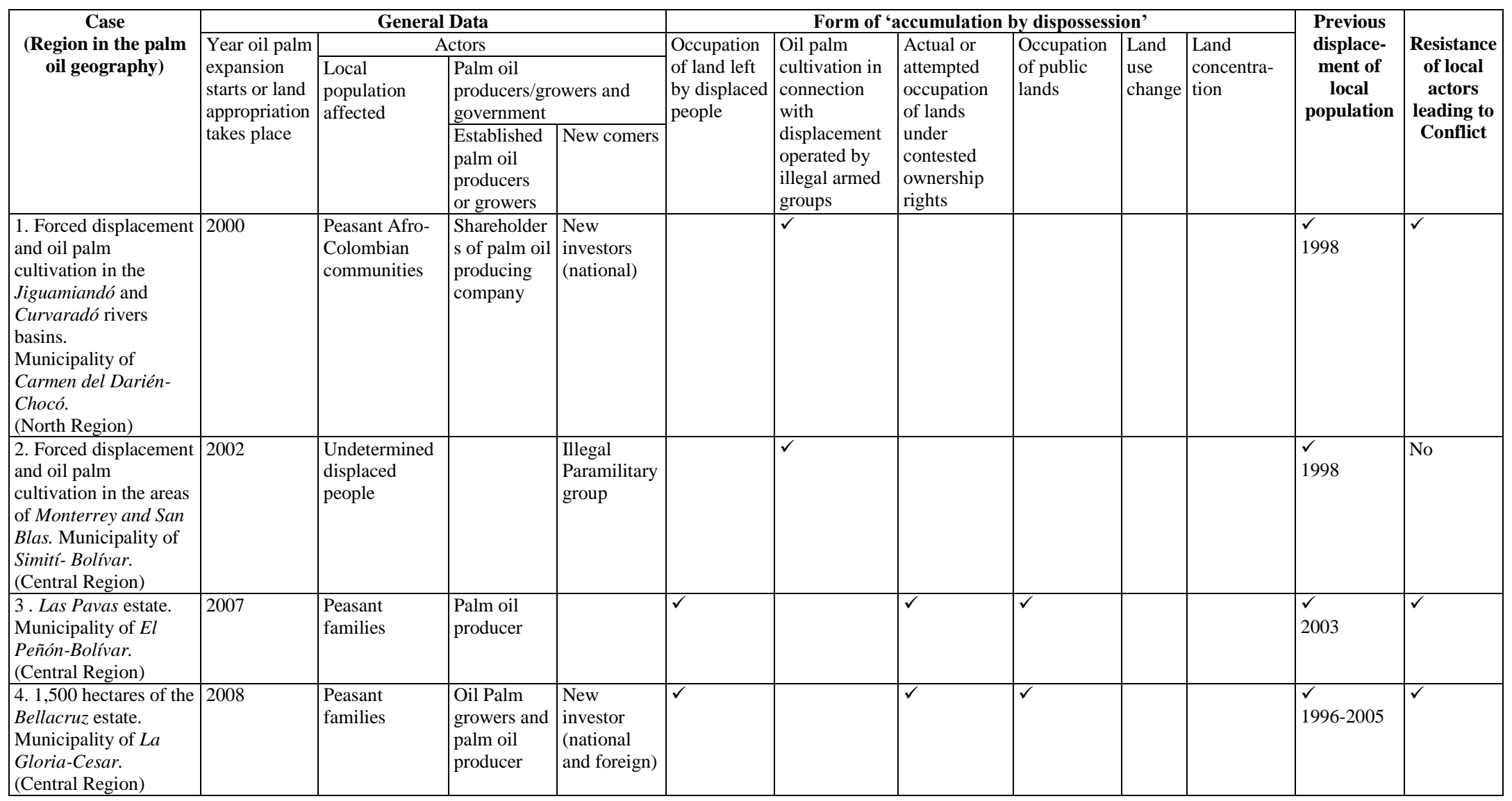




\begin{tabular}{|c|c|c|c|c|c|c|c|c|c|c|c|}
\hline $\begin{array}{l}\text { 5. Plots in the middle } \\
\text { of palm oil plantations } \\
\text { used by peasants for } \\
\text { small-scale subsistence } \\
\text { farming. Municipality } \\
\text { of San Alberto-Cesar. } \\
\text { (Central Region) }\end{array}$ & $2003-2004$ & $\begin{array}{l}\text { Peasant } \\
\text { families }\end{array}$ & $\begin{array}{l}\text { Palm oil } \\
\text { company }\end{array}$ & & & $\checkmark$ & & & & No & $\checkmark$ \\
\hline $\begin{array}{l}\text { 6. Massive } \\
\text { establishment of oil } \\
\text { palm by different } \\
\text { actors in the } \\
\text { Municipality of Simití- } \\
\text { Bolívar. } \\
\text { (Central Region) }\end{array}$ & 2000 & $\begin{array}{l}\text { Peasants and } \\
\text { landless people }\end{array}$ & $\begin{array}{l}\text { Palm oil } \\
\text { producers/ } \\
\text { growers }\end{array}$ & \begin{tabular}{|l|} 
Public- \\
private \\
alliances, \\
new \\
investors \\
(national/ \\
foreign), \\
and small- \\
holders \\
\end{tabular} & & & $\checkmark$ & $\checkmark$ & & \begin{tabular}{|l|}
$\checkmark$ \\
$1998-2006$
\end{tabular} & No \\
\hline $\begin{array}{l}\text { 7. Oil palm oil } \\
\text { cultivation in Afro- } \\
\text { Colombian collective } \\
\text { territories of Alto Mira } \\
\text { and Frontera } \\
\text { Municipality of } \\
\text { Tumaco-Nariño. } \\
\text { (South-west Region) }\end{array}$ & 2000 & $\begin{array}{l}\text { Peasant Afro- } \\
\text { Colombian } \\
\text { community }\end{array}$ & $\begin{array}{l}\text { Palm oil } \\
\text { producers/ } \\
\text { growers }\end{array}$ & & & $\checkmark$ & & & & No & $\checkmark$ \\
\hline $\begin{array}{l}\text { 8. Massive } \\
\text { establishment of oil } \\
\text { palm. Municipality of } \\
\text { Zona Bananera- } \\
\text { Magdalena. } \\
\text { (North region) }\end{array}$ & 2003 & $\begin{array}{l}\text { Peasants and } \\
\text { landless people }\end{array}$ & & & $\checkmark$ & & & $\checkmark$ & $\checkmark$ & & No \\
\hline $\begin{array}{l}\text { 9. Guapi Abajo palm } \\
\text { oil project. } \\
\text { Municipalty of Guapi- } \\
\text { Cauca. } \\
\text { (South-west Region) }\end{array}$ & 2007 & $\begin{array}{l}\text { Peasant Afro- } \\
\text { Colombian } \\
\text { communities }\end{array}$ & & $\begin{array}{l}\text { Government } \\
\text { Afro- } \\
\text { Colombian } \\
\text { community } \\
\text { member of } \\
\text { 'productive } \\
\text { alliance' } \\
\end{array}$ & & & & $\checkmark$ & & No & $\checkmark$ \\
\hline
\end{tabular}




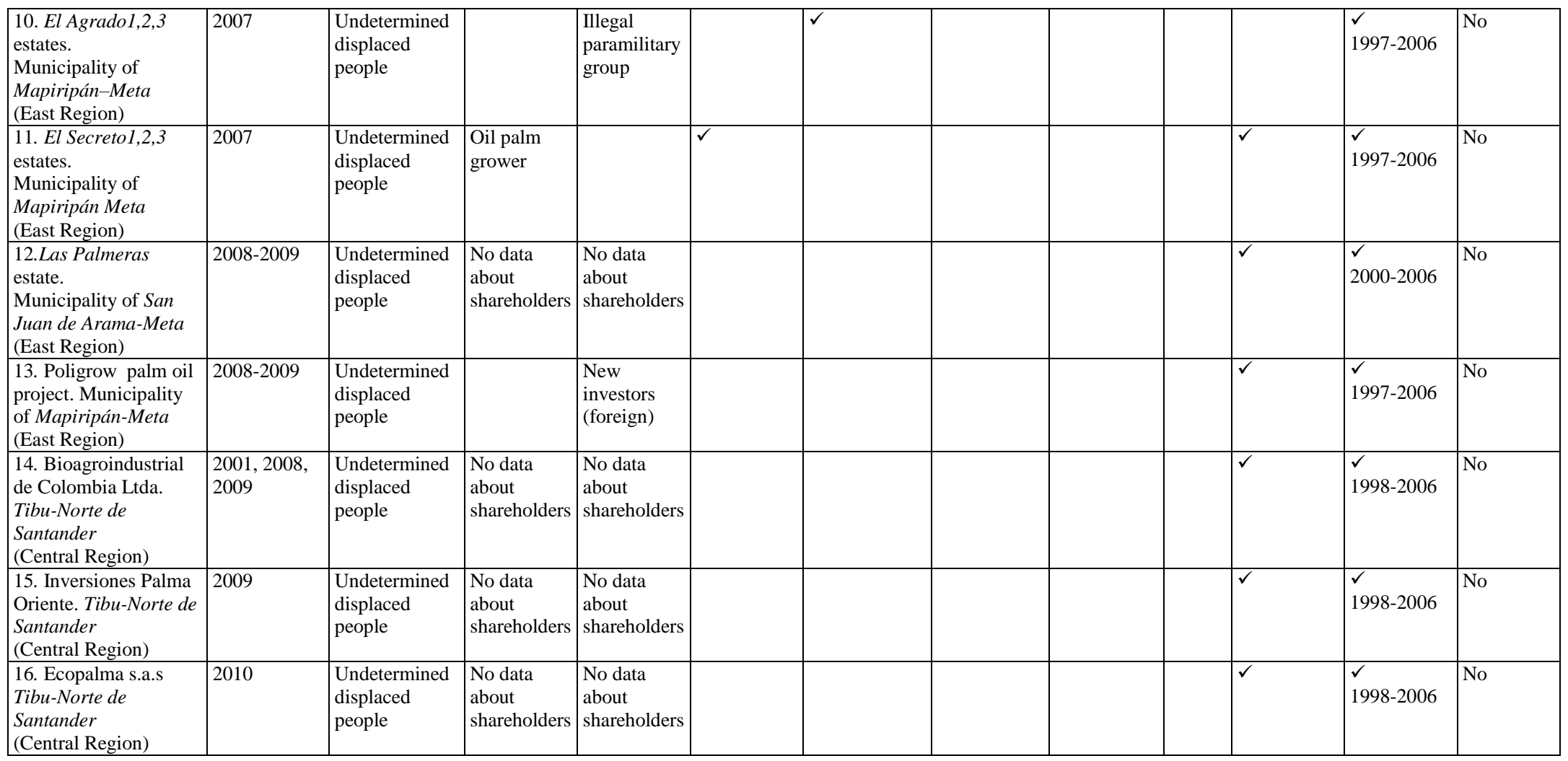

Source: Own construction. See Appendix B - Table B.1 for details of the cases and the sources of data. 
The case of displacement of communities of Afro-Colombians in the Jiguamiando and Curvaradó river basins (Case 1 in Table 3.4) is recurrently cited in the literature reporting the negative effects of the palm oil expansion in Colombia (Comision Intereclesial de Justicia y Paz, 2007; Franco and Restrepo, 2011; Friends of the Earth, 2008; Houldey, 2008; Mingorance, 2006; Oosterkamp et al., 2007).

However, must of the cases of 'accumulation of dispossession' in Table 3.4 have involved other types of land control practices deployed by established palm oil producers/oil palm growers and new investors. Thus the practices of 'accumulation of dispossession' can be analytically grouped into six categories (Fig. 3.11 and Table 3.4):

i) Oil palm cultivation in connection with displacement operated by illegal armed groups

ii) takeover of land left by internally displaced people,

iii) actual or attempted occupation of lands under contested ownership rights,

iv) occupation of public lands,

v) land use change, and

vi) land concentration

Each case in Table 3.4 does not belong exclusively to one of these categories since two or more forms of 'accumulation by dispossession' intertwine in several cases. This combination of forms of 'accumulation by dispossession' demonstrates the complexity of the trajectories of the contemporary expansion of the palm frontier in the 'space-of-place'. The remainder of this section describes them in more detail.

Due to the historical high levels of land concentration, people in rural areas in Colombia have relied on different land tenure arrangements and practices to gain or maintain access to land that do not necessarily imply ownership. Landless people have historically resorted to land-rental and sharecropping agreements with landowners in order to have access to land to sustain their livelihoods (Lastarria-Cornhiel, 1998; Meertens, 1985). Thus, tenants and sharecroppers may end up being dispossessed from their livelihoods when landowners decide to change the use of land to oil palm cultivation (Cases 6 and 8 in Table 3.4).

In Case 6 (Table 3.4), dispossession occurs simultaneously with 'assimilation' since some of the landowners were local farmers that entered into oil palm cultivation through 'productive alliances'. Another case in which 'assimilation' and dispossession occur simultaneously in a context of land use change is Case 9 (Table 3.4). However, in this case 
the affected are not landless peasants, but Afro-Colombian communities with land collective titles recognised under the Colombian law. ${ }^{25}$

In case 9 (Table 3.4), the land use change when oil palm was introduced affected the environmental conditions of the neighbouring communities' territories. As a consequence, this land use change put at risk the traditional uses of the land that constituted the basis of the livelihoods of those communities not incorporated into 'productive alliances' resulting in a socio-environmental conflict between Afro-Colombian communities.

Another landless peasants' common practice to access land has been the use of two types of public lands:

i) public lands for public use the ownership of which is reserved exclusively for the state or a public entity, such as communal savannahs and marchlands that have been traditionally used by local communities. According to the Colombian Agrarian Law (Law 160, 1994), this type of public lands can be used by local populations for cattle grazing, fishing, and subsistence food production. These public lands cannot be appropriated or enclosed, and the use of these lands by local communities cannot be obstructed through the private construction of infrastructure such as canalisations, dikes or fences (Law 160, 1994 - Article 69).

ii) Public lands intended to be titled by the government to individuals or peasant associations who are able demonstrate that they have occupied and used the land for their productive activities for at least five years (Law 160, 1994 - Articles 65 and 69). According to the Colombian Agrarian Law, the amount of land that can be titled corresponds to the Unidad Agrícola Familiar - UAF (Family Agricultural Unit), i.e. the amount of land that a peasant family needs to carry out the basic productive activities for a peasant livelihood (Law 160, 1994 - Articles 38 and 65). The extension of the UAF varies from one region to the other since it depends on the agro-ecological conditions of each region.

There are situations in which the livelihoods of landless peasants depend on access to the aforementioned two types of public lands. Therefore, unlawful occupation and appropriation of these lands by oil palm growers to expand the frontier has led to peasants' livelihood dispossession. For example, in case 6 (Table 3.4), public communal savannahs and marshlands used by landless people for fishing or growing short cycle crops were unlawfully taken over by oil palm growers.

\footnotetext{
${ }^{25}$ The right of Afro-Colombians to their ancestral territories is recognised in the Constitution of Colombia adopted in 1991. Law 70, 1993 contains the norms governing the definition and collective titling of Afro-Colombian territories.
} 
It is common that peasants settle in the second type of public lands (public lands intended to be titled by the government to individuals or peasant associations) and maintain access on the basis of informal land tenure practices. In some cases these peasants apply for recognition of property rights and titling only when their access is threatened or contested and land tenure conflicts emerge. This is the situation in Cases 3, 4 and 5 (Table 3.4).

In Cases 3 and 4 (Table 3.4), peasants' land access was threatened by wealthy landlords that seized public lands to which peasants had the right to obtain the titles. As a response, peasants started the legal procedure for the recognition of their property rights. However, access to land was further hindered by forced displacement as peasants had to abandon the lands under the pressure of illegal paramilitary groups. The displacement allowed the consolidation of the land grab conducted by the landlords, who fraudulently sold it to established palm oil producers and new investors for the expansion of the palm oil frontier. Although the palm oil producers and investors were not involved in the actions of displacement, they exacerbated and deepened dispossession by appropriating and establishing oil palm plantations on public land the ownership of which was legitimately claimed by peasants.

Further dispossession materialised when peasants attempted to return to the lands and were physically prevented from doing so by palm oil companies. The land ownership struggle turned into a socio-environmental conflict as oil palm cultivation constitutes an extractive activity that peasants reject and regard as harmful for their lands, while the oil palm growers see it as legitimate business.

In Case 5 (Table 3.4), a large-scale palm oil company has threatened to evict peasants from small-holdings located on public land that the peasants have used for more than two decades. The palm oil company claims the property of such plots in order to incorporate them into their established plantation. In response, the peasants began a legal process, with the support of a local NGO, for the recognition of their property rights. The palm oil company has also resorted to legal procedures and de facto threats to restrict peasants' access to the land and appropriate it on the basis of the contested ownership rights, so operating a form of 'accumulation by dispossession' that resulted in a socio-environmental conflict. $^{26}$

'Accumulation by dispossession' through the occupation of lands under contested ownership rights not only occurred in cases involving public lands, but also in territories of Afro-Colombian communities. In Case 7 (Table 3.4), territories of Afro-Colombian communities were partially invaded by oil palm growers while the communities were

\footnotetext{
${ }^{26}$ See a detailed discussion of this case in Chapter 5.
} 
waiting for the collective title that recognised their property rights on the basis of a law that recognise Afro-Colombians' right to their ancestral territories. ${ }^{27}$

In Cases 1, 3, 4, 5, 7 and 9 (Table 3.4), agrarian land disputes take the form of socioenvironmental conflicts as peasants and Afro-Colombian communities not only claim access to land, but also contest the expansion of oil palm cultivation as they consider that it harms the material basis that sustains their livelihoods.

All the cases of land control through 'accumulation by dispossession' previously explained started to be unveiled during Uribe Vélez's government (2002-2010) by NGOs, state agencies protecting human rights and researchers concerned with the local effects of the governmental policies aimed at promoting biodiesel demand and production.

However, the emphasis that the subsequent government of Juan Manuel Santos (2010-2014) put on land restitution has led to the investigation and discovery of other land control practices of 'accumulation by dispossession' for the expansion of the palm frontier. For example, there has been unlawful concentration of land by established oil palm growers and new investors in municipalities that have been subject to large-scale forced displacement and land grabbing. Cases 11, 12, 13, 14, 15 and 16 (Table 3.4) are illustrative of this practice.

At the time of writing, these cases were still under formal investigation by the government. However, from the information available at the time of writing it appears that palm oil growers designed strategies to circumvent the Colombian Agrarian Law so that they could accumulate lands that:

i) amounted to extensions larger than those permitted by the law, and or

ii) were reserved to be assigned to landless peasants or were left by people subject to forced displacement.

Therefore, the establishment of oil palm plantations using this form of land control reinforces the processes of dispossession suffered by peasants and victims of internal displacement. An academic study reports that also in Case 8 (Table 3.4) established palm oil producers and new comers took over lands left by displaced people to expand or establish oil palm plantations (Goebertus, 2009).

A paradoxical situation that emerged from a land restitution process is that of a smallholding oil palm grower who had been displaced and had entered into oil palm cultivation

${ }^{27}$ Law 70, 1993. 
using a piece of land that he bought in good faith from a third party. The land was previously owned by other displaced family that claimed restitution since they had sold the land to the third party forced by the circumstances of violence connected with the armed conflict (Tribunal Superior del Distrito Judicial de Cúcuta, 2013).

Although this situation is unique, more situations like this could emerge as implementation of the land restitution programme advances. Therefore, it is worthwhile to mention it because it contributes to our understanding of the complexity of the ways in which national and local socio-politic circumstances mould the expansion of commodity frontiers giving way to country-specific trajectories that combine 'assimilation' and dispossession. Indeed, the cases in which 'accumulation by dispossession' occurs simultaneously with 'assimilation' demonstrate that "the mechanisms of land control need not always align, nor proceed in a singular, linear direction. They may be wielded in concert or competition with one another" (Peluso and Lund, 2011: 668).

Although not all the cases in Table 3.4 resulted in socio-environmental conflicts, they all entail the dispossession of local people's livelihoods. This means that the land control practices of 'accumulation by dispossession' connected with the expansion of the palm oil frontier not only deprive affected local people from the material means to make a living, but also from the culture, identity and kinship-based social relationships that some groups inhabiting rural areas attach to the territory (see Chapters 5 and 6).

In the cases in Table 3.4, 'accumulation by dispossession' has been directly or indirectly facilitated by the processes of peasant marginalization and displacement. The process of "emptying the lands" that resulted from forced displacement is a common underlying element to almost all the cases in Table 3.4. All the municipalities where these cases are located have been subject to high levels of displacement between 1998 and 2006, except the municipality of Case 4 which presents medium levels of displacement (see Map 3.2). Yet, in Case 4, displacement was part of the history of dispossession that indirectly facilitated the establishment of oil palm cultivation in lands claimed by peasants.

The government and the palm oil agro-industry have wrapped the contemporary expansion of the palm oil frontier within the package of an inclusive activity that could contribute to peace and development in rural areas. However, the processes of marginalization and displacement on which this expansion has been built demonstrate that violence and dispossession underlie today's palm oil frontier.

Marginalization and displacement also seem to have constrained the possibilities of resistance, so influencing the emergence of socio-environmental conflicts. The analysis of the cases in Table 3.4 shows that resistance has only arisen in the cases in which the 
circumstances of displacement and the disempowerment caused by marginalization were at least partially overcome, i.e.:

i) when the conditions that led to displacement ceased or were tempered and people attempted to return to their lands finding them occupied with oil palm cultivation projects (Cases 1, 3 and 4), and/or

ii) when the affected people were united in a collective form of organization supported by grassroots organizations, national and international NGOs, and state or international entities in charge of ensuring rights protection such as the Office of the Ombudsman and the local, national and international courts (Cases 1, 3, 4, 5, 7 and 9).

This is consistent with Conde and Kallis (2012) findings about the influence that socioeconomic factors and "cross-scalar links" with external actors have on the emergence of resistance.

In some cases, resistance succeeded in achieving recognition of affected people claims (Cases 1, 3, 4, 5, 7) and/or preventing the advancement of oil palm cultivation on the contested lands (Cases 1, 3 and 5). These achievements show how local people can actually exercise power through resistance to counteract land control practices of dispossession and stop the expansion of extraction frontiers in their territories.

The dynamics of conflict and resistance identified in this section indicate that latent conflicts that may be still hidden in the new palm oil frontiers may break out once the resistance silenced by violence and marginalization finds the momentum and support to emerge. Latent conflicts may well arise if the investigation into land misappropriation that started under Santos' government continue.

\subsection{Conclusions}

The current phase of capitalist expansion is characterised by an accelerated expansion of commodity frontiers through practices of 'assimilation' and 'accumulation by dispossession' that often lead to socio-environmental conflicts. However, the trajectories that such expansion takes in the countries of commodities extraction and production, as well as the responses of local people, are shaped by country-specific geographies and processes.

In this chapter I draw on the situation of the contemporary expansion of the palm oil frontier in Colombia to explore how global expansion of commodity frontiers interact with national geographies and social-economic and political processes to produce country- 
specific trajectories of expansion and resource access control. I use an analytical framework that positions the country-specific trajectories of frontier expansion within the 'space-offlows' (markets) and the 'space-of-place' (localities) of commodity frontiers, combining concepts from political ecology and political economy.

The analysis shows that, in contrast with the world largest palm oil producing countries Indonesia and Malaysia (Hall, 2011; Pye, 2010) -, the trajectories of expansion of the palm oil frontier in the 'space-of-flows' in Colombia between 2000 and 2010 were not strongly influenced by the international market. Conversely, expansion in the 'space-of-flows' was characterised by an increasing production of palm oil to be processed into biodiesel in order to supply a policy-driven national biofuel market controlled by national palm oil producers.

Exports increased only during the period necessary to establish the national biodiesel industry, as palm oil producers needed an outlet to place the palm oil surplus that could not be absorbed by the national market for traditional uses. This particular trajectory was shaped by a combination of several interrelated factors:

i) high levels of integration of different processes of the commodity chain controlled by national entrepreneurs,

ii) the lack of competitiveness at the international level,

iii) the saturation of the national market for traditional uses,

iv) business opportunities in the international market that emerged from a raising global demand for palm oil partially driven by a global biofuel boom,

v) the flex-crop nature of palm oil, and

vi) the strong governmental support to the palm oil agro-industry. The influence of the governmental support was so significant in what has happened that it merits a separate and more detailed analysis (Chapter 4).

This country-specific trajectory of expansion of the palm oil frontier in the 'space-of-flows' demonstrates that establishing direct cause-effect relationships between expansion of the palm oil frontier in the Global South and policy-driven biofuel demand in the Global North is rather simplistic. It overlooks the complex and interrelated factors that mediate the specific ways in which global commodity booms translate into country-specific trajectories of commodity frontiers expansion.

In the 'space-of-place', the land control practices for the expansion of the palm oil frontier in Colombia follow patterns of 'accumulation by dispossession' and small holding farmers incorporation through contract farming. 
Contract farming arrangements called 'productive alliances' represent one of the dominant trajectories of expansion in the 'space-of-place'. However, the group of local people engaged in these alliances is sufficiently heterogeneous that further research is required in order, firstly, to assess the extent of 'assimilation' and 'adverse incorporation' and, secondly, to elucidate whether these schemes resemble or differentiate from similar forms of incorporation identified in other palm oil producing countries (McCarthy, 2010; Rist et al., 2010).

The expansion of the frontier has also involved land control practices of 'accumulation by dispossession' as in other producing countries, in particular Indonesia (Colchester et al., 2006; Sirait, 2009). However, a country-specific set of practices has been identified from the analysis of a number of cases in Colombia.. Moreover, each situation entailed dispossession of local people's livelihoods in a different guise, involving one or more of such practices. Resistance emerged in specific cases leading to socio-environmental conflicts, as in other palm oil producing countries, such as Indonesia (Colchester et al., 2006; Sirait, 2009). In some cases, resistance against the extractive activity intertwined with land agrarian disputes rooted in a long history of inequitable distribution of land. Thus, when historical dispossession was exacerbated by the establishment of oil palm plantations land agrarian disputes evolved into socio-environmental conflicts.

Incorporation and 'accumulation by dispossession' have been also identified in other producing countries, such as Indonesia and Malaysia (Colchester et al., 2006; McCarthy and Cramb, 2009). However, governmental support to the agro-industry, peasant marginalization, and socio-political processes connected with the armed conflict - such as alternative development programmes and forced displacement -, have shaped the countryspecific forms that such land control practices have taken in Colombia.

However, in Colombia, displacement and marginalization are not exclusive to the municipalities of the palm oil frontier as they are a country-wide phenomenon. Nor has governmental support exclusively favoured the palm oil agro-industry.

Thus, the connection of these factors and processes (governmental support to the agroindustry, peasant marginalization and displacement) with the expansion of the palm oil frontier indicates that in the case of Colombia the combination of these factors and processes facilitates the expansion of extraction frontiers through varied and in some cases interrelated forms of 'accumulation by dispossession' and 'assimilation'. 
It is possible to draw some conclusions about the interaction between global expansion of commodity frontiers and country-specific trajectories of expansion and resource access control from the analysis presented in this chapter about the case of Colombia.

Firstly, the country-specific trajectories of expansion of the palm oil frontier in Colombia demonstrate that commodity booms at a global scale (in terms of accelerated increase in demand and production) and the forms of expansion of commodity frontiers at the national and local scales are mediated by complex interrelations between national geographies and social, economic and political factors that often have historical roots. Therefore, generalised explanations about the causes, effects and forms of expansion of a commodity frontier based on overall observations at the global level or on single country case studies may result in misleading conclusions as regards both global dynamics of expansion and expansion in other producing countries. A better understanding of the dynamics of expansion of commodities frontiers requires research at the country/local levels as well as comparative analysis across countries and localities.

Secondly, the case study findings support Hall's emphasis on the relevance of the features of the crop to understand trajectories of expansion in the case of 'crop booms' (Hall, 2011). The Colombian case shows how the 'flex crop' nature of palm oil makes it possible for palm oil producers to align the trajectories of expansion in the 'space-of-flows' with new market opportunities that are more profitable. This supports the conclusion by Borras et al. (2012) that the accelerated expansion of 'flex crops' during the current phase of capitalism is logical since these crops' versatility allows continuous capital accumulation in a context of multiple converging crises (Borras et al., 2012: 851).

Thirdly, although global expansion of commodity frontiers often entails 'accumulation by dispossession' (Harvey, 2003, Muradian et al., 2012), the case of Colombia demonstrates that it also proceeds through practices of 'assimilation'. Moreover, the analysis carried out in this chapter corroborates Harvey's observation that "accumulation by dispossession can occur in a variety of ways and there is much that is both contingent and haphazard about its modus operandi" (Harvey, 2003: 149). The study of the case of Colombia shows how such ways and modus operandi are shaped by social, economic and political processes specific to the territories of extraction resulting in country-specific forms of: i) 'accumulation by dispossession', ii) 'assimilation', and iii) resistance and conflict.

Finally, in spite of the specificity of the trajectories of the expansion of a commodity frontier in each producing country, those trajectories can be placed in the broader global context as they correspond with general process associated with capitalist expansion at the global scale. For example, the specific trajectories of land control practices associated with 
the expansion of the palm oil frontier in Colombia are immersed in a global dynamic of resource extraction in which a "series of changing contexts, emergent processes and forces, and contestations [are] producing new conditions and facilitating shifts in both de jure and de facto land control" (Peluso and Lund, 2011: 669). 
Chapter 4

\section{Governmental Support, Power and Access to Resources: Access to Land and Governmental Support to the Palm Oil Agro-industry in Colombia}

\subsection{Introduction}

In this chapter I address Research Sub-question 2 of this dissertation: How do governmental incentives to support extractive activities mediate actors' power asymmetries in access to resources?

Governments often stimulate the expansion of extractive activities in the name of development, so influencing who gains access to resources and how (Bebbington, 2012a; Svampa, 2011). Thus, governmental support often mediates power asymmetries in access to resources for the expansion of commodity frontiers. Studies on the influence of policies on access to resources focus mainly on the content and implementation of policies that set the rules for access to, or management of, the specific resource in question. ${ }^{1}$ This is the case of the research on the relations between land governance regimes or forestry policies, and local population's access to land or forests (Broegaard, 2009; Larson and Ribot, 2007; Lund, 2009).

However, little attention has been paid to policies, laws and governmental measures that support the development of economic activities based on the extraction and exploitation of resources. In this chapter, I explore how governmental support to the expansion of commodity frontiers mediates power asymmetries in access to resources. I do so by applying Ribot and Peluso's 'theory of access' to the analysis of the policy environment that supported expansion of the palm oil frontier in Colombia between 2000 and 2010. Since such expansion is at the basis of socio-environmental conflicts over access to land, I explore: how such policy environment enabled access to land; whose access was enabled and whose was hindered; and, how the beneficiaries were able to influence policy-making and implementation.

Conflicts over land in Colombia have complex historical roots that have resulted in the concentration of land, dispossession, and the violent appropriation of the lands inhabited by peasants, indigenous people and Afro-Colombian communities in rural areas. Historically,

\footnotetext{
${ }^{1}$ Some exceptions are the studies carried out by: i) Corbera and Brown (2010) on access in cases of forestry projects for carbon sequestration and climate change mitigation policy; and ii) Wagle et al. (2012) on access to water and the policies supporting the development of dams in India.
} 
governments' response to addressing this conflicting situation has been the recognition of the ancestral territorial rights of indigenous people and Afro-Colombians, and some failed attempts of agrarian reform, coupled with rural development policies. These land governance and rural development measures have been presented as land access opportunities for peasants, indigenous people and Afro-Colombian communities living in rural areas. Yet disputes over access to land and territorial rights that take the form of socioenvironmental conflicts have continued to emerge or have exacerbated in connection with the expansion of extraction frontiers. Agro-industry, mining, timber production and large infrastructure projects - such as the construction of dams - are examples of the extractive activities the increase of which is at the basis of socio-environmental conflicts in Colombia. $^{2}$

As presented in Chapter 3, the expansion of the palm oil frontier since the year 2000 is representative of this dynamic. Governmental support has been a key driver of this expansion. Since the 1960s, oil palm cultivation and palm oil production have benefited from several of the various instruments and stimulus aimed at supporting the development of the agricultural sector (Aguilera, 2002; García Reyes, 2011). However, the institutional support that gave a major boost to this agro-industry started at the end of the 1990s and was reinforced markedly during Álvaro Uribe Vélez's two consecutive governments between 2002 and 2010.

This chapter is structured as follows: in Section 4.2, I present a brief explanation of the theoretical underpinning and methods that inform the analysis. In Section 4.3, I analyse how governmental support to the palm oil agro-industry mediates actors' power asymmetries in access to land in the case of Colombia. Section 4.3 is divided in three sections: in Section 4.3.1, I briefly explain how governmental support to the palm oil agro-industry is placed in the context of the Colombian agrarian history. In Section 4.3.2, I analyse how such governmental support to the palm oil agro-industry embodies structural mechanisms of access, how those mechanisms enabled access to land, and who benefited from them. To complement this analysis, in Section 4.3.3, I explore the relational 'bundles of power' that consented oil palm growers/palm oil producers to influence policy-making and implementation in their favour.

This chapter ends with some conclusions about the findings of this analysis, and the relevance of analysing governmental interventions aimed at supporting extractive industries

\footnotetext{
${ }^{2}$ For example, the Observatory on Mining Conflicts in Latin America - OCMAL (an initiative of more than 40 Latin American organizations engaged in activism against the negative socioenvironmental impacts of mining activities in the region) reported that there were 12 cases of active conflicts connected with mining activities in Colombia in January 2014 (OCMAL, 2014). There are also cases of conflicts connected with dam constructions for hydropower production such as $\mathrm{El}$ Quimbo dam and Hidrosogamoso dam.
} 
in order to unveil the structural and relational mechanisms of access that shape the political economies of resource extraction.

\subsection{Conceptual and analytical framework: the theory of access and access analysis}

Building upon political economy and political ecology, Ribot and Peluso (2003) define access as "the ability to benefit from things", and provide a categorization of mechanisms of access beyond property rights. The distinction between access control and access maintenance reveals the political-economic underpinning of the concept, because both control and maintenance "are constitutive relations among actors in relation to resource appropriation, management, or use". While "access control is the ability to mediate others' access", access maintenance means "expending resources or powers to keep a particular sort of resource access open" for oneself. In addition, Ribot and Peluso introduce the term gaining access to refer to "the more general process by which access is established" through different means, including not only legal means such as formal and informal institutions, but also illegal means (Ribot and Peluso, 2003: 159).

Under Ribot and Peluso's theory, access is about all possible means that shape the ability to derive benefit from things, i.e. the means to gain, control or maintain access. It considers not only the means intended to impart property rights, but also the means "that are not socially sanctioned in any domain of law, custom or convention", such as structural forces, discursive manipulations, relations of production and exchange, and even socially and legally forbidden acts or means (Ribot and Peluso 2003: 156).

Thus, access analysis is the empirical process of deriving "from the fact of access to benefits, or appropriation, the repertoire of mechanisms supporting access" (Ribot, 1998: 312; Ribot and Peluso, 2003: 160). Access analysis "does not presume any set of rights, structures, processes, and so forth" that confer the ability to benefit from things; instead, access analysis derives the repertoire of mechanisms supporting access from observed practice (Ribot, 1998: 312). However, Ribot and Peluso propose a categorization of access mechanisms that can be used for analytical purposes (Ribot and Peluso, 2003: 173). It includes both right-based and illegal mechanisms of access, as well as structural and relational mechanisms.

Legal means of access take the form of property rights or other forms of tenure defined by laws and policy instruments that confer rights, such as land tenure regimes or forestry policies. Ribot and Peluso refer to these legal means as rights-based mechanisms of access. However, access can be also gained, controlled or maintained through illegal means like violence or theft (Ribot and Peluso, 2003: 164). 
Access may be also shaped by structural and relational mechanisms that "mediate or operate parallel to rights-based and illegal mechanisms". These mechanisms include technology, capital, market, labour, knowledge, authority, identities and social relations (Ribot and Peluso, 2003: 162). These are the access mechanisms at play in the case of governmental support to extractive activities since this type of interventions are not typically aimed at establishing resource tenure regimes.

The different mechanisms of access are the strands of "bundles of power" that enable social actors to gain, control or maintain access to resources (Ribot and Peluso, 2003: 158). Thus, the forms of access to and control over resources constitute "political economies of power and accumulation" (Peluso, 2009: 40). This idea is informed by a Foucauldian conception of power according to which power is not a fixed characteristic of actors. Conversely, it is relational. It "has as much to do with positionality as with the formal powers that people might hold" (Ribot and Peluso, 2003: 158). In Foucault's view, power "is not an institution, and not a structure; neither is it a certain strength we are endowed with; it is the name that one attributes to a complex strategical situation in a particular society" (Foucault, 1978: 93). Thus, the ways in which access mechanisms enable some social actors to gain, control or maintain access to resources is connected with the position of those actors within their social relations.

In this chapter I present the results of an access analysis that focused on:

i) the identification of structural and relational mechanisms of access embodied in the governmental incentives that supported the expansion of the palm oil frontier in Colombia between 2000 and 2010, and

ii) how these mechanisms shaped oil palm growers' and palm oil producers' access to land.

The analysis followed a two-pronged strategy.

First, I carried out an empirical identification of the different governmental incentives and stimulus that supported the contemporary development of the palm oil agro-industry. Once identified, I analysed this governmental support in light of the structural mechanisms of access in order to establish how they enabled access to land and who benefited from them.

Second, I analysed the relational mechanisms of access that enabled the palm oil agroindustry to influence governmental support, i.e. the analysis of how the palm oil agroindustry was positioned in relation to government. For this last part of the analysis I drew 
on methods that are used in power structure research to map membership networks (Domhoff, 2006). ${ }^{3}$

Data was drawn from various primary and secondary sources:

i) documents and secondary information produced by the palm oil agro-industry, the government, researchers and journalists reporting the historical governmental support to the palm oil agro-industry, in particular between 2000 and 2010, and

ii) interviews and observations obtained from fieldwork carried out during JanuaryFebruary 2010 and August-December, 2011.

\subsection{Governmental support to the palm oil agro-industry and access to land in Colombia}

\subsubsection{Contemporary governmental support to the palm oil agro-industry in context}

Governmental support to the development of the palm oil agro-industry in Colombia, and the consequential expansion of the palm oil frontier, need to be understood in light of the historical agrarian structure and the model of rural development in which they are embedded. Inequitable distribution of access to land expressed in high levels of land concentration is a characteristic of the Colombian agrarian history (Fajardo Montaña, 2009). ${ }^{4}$ They both date from the colonial times (Kalmanovitz and López Enciso, 2006; Reyes Posada, 2009), and are at the basis of a dualistic agrarian structure in which smallholding peasant agriculture coexists with capitalist agriculture (Machado, 1998 and 2002). ${ }^{5}$

Historically, capitalist agriculture has used large land holdings in the most fertile lands and has had more access to credit resources, incentives and technical assistance than smallholding peasants' agriculture (Machado, 1998 and 2002). Since the 1960s, different governments have favoured capitalist agriculture considering it the driving force of rural development. They have done so by promoting the agro-industrial model of production used in capitalist agriculture and the agro-industrial production of crops with potential for

\footnotetext{
${ }^{3}$ Power structure research studies power by constructing the network of actors through which power is exercised (Domhoff, 2007).

${ }^{4}$ Land concentration Gini coefficient has been historically over 0.8 in Colombia (IGAG, 2012). The Gini coefficient is a measure for inequality. Land concentration Gini coefficient measures equality in the distribution of land ownership. Gini coefficient of 0 represents perfect equality. A Gini coefficient of 1 represents maximum inequality.

${ }^{5}$ In this dissertation I adopt Jan Dowe van der Ploeg's definition of capitalist agriculture as the agriculture in which the labour force and other resources are commodified, and which is "geared towards and organized as a function of profit maximization" (Ploeg, 2008).
} 
exports (Machado et al., 2013). ${ }^{6}$ Oil palm is a typical crop of capitalist agriculture (ForeroÁlvarez, 2002) that has been cultivated under the agro-industrial model and has been considered as a promising crop by different governments. Oil palm cultivation and palm oil production have received governmental support since the 1960s (Aguilera, 2002; García Reyes, 2011; see Section 3.3 in Chapter 3).

However, governmental support to this agro-industry was strengthened since the late 1990s, especially during Álvaro Uribe Vélez's governments between 2002 and 2010. As a result, the area cultivated with oil palm increased from 157,000 hectares in 2000 to 404,000 hectares in 2010 (Fedepalma, 2005 and 2011a). This is a remarkable growth considering that in the previous 30 years the area cultivated passed from about 20,000 hectares in 1970 to 150,000 hectares in 1999 (Aguilera, 2002).

During Andres Pastrana's government (1998-2002), palm oil was categorized as a promising agro-industrial product. The palm oil agro-industry sector had already signed an agreement with the previous government, which was part of a broader strategy aimed at enhancing the competitiveness of the "oil seeds and oils and fats production chain" (Mesa Dishington, 2009). But after the agreement, two interventions of Andres Pastrana's government in the agricultural sector were very relevant for the future development of palm oil agro-industry:

i) a national governmental programme to promote a business model called 'productive alliances' through which small-scale farmers are integrated in the production chain of different agricultural sub-sectors $;^{7}$ and

ii) the applicability of an agricultural subsidy called rural capitalisation incentive (ICRIncentivo de capitalización rural) to the planting and maintaining of late-maturing crops such as oil palm. Through the ICR subsidy, the government reimburses a percentage of the agricultural credit that a producer has acquired with a bank to invest in certain agricultural activities. When the ICR was created in 1993 (Law 101,

\footnotetext{
${ }^{6}$ By agro-industrial model of production I understand the model of agricultural production that adopts the principles, strategies and techniques that characterise industrial processes, such as "large-scale production sites, mechanization, standardization of product, specialization, speed of throughput, routinization of the workforce, and a belief that success [is] based first and foremost upon a notion of 'efficiency"' (Fitzgerald, 2003: 5).

${ }^{7}$ The programme was initially designed by the Minister of Agriculture Carlos Murgas (1998-1999) in 1998. However, it materialised in 2002 when the government could obtain co-funding support from the World Bank. The programme has been partly financed with credits from the World Bank since 2002 (CONPES, 2001 and 2007a). Part of the World Bank credit has been allocated to provide small producers involved in the alliances with a subsidy. Besides this subsidy, substantial financial support for projects under the 'productive alliances' model has come from other governmental incentives (see Section 4.3.2) and international cooperation aid (See Chapter 3).
} 
1993), it did not support finance for planting and maintaining oil palm. The government broadened the scope of the subsidy in 1999 by allowing its use for the planting and maintaining of late-maturing crops - such as oil palm - by small-scale growers. Since 2000, medium and large-scale growers could also apply for the incentive.

These two interventions largely contributed to the contemporary trajectories of expansion of the palm oil frontier in Colombia detailed in Chapter 3. The expansion of oil palm cultivation between 2000 and 2010 was largely financed through the ICR (see Section 4.3.2.1 below). About $25 \%$ of such expansion took the form of 'productive alliances' (see Chapter 3).

Since 2002, Álvaro Uribe Vélez's government started to promote palm oil production more intensively. A wide range of instruments, such as tax exemptions, price regulations to guarantee producers minimum income, agricultural credit and subsidies, and policies to stimulate demand, were adopted and implemented to support a rapid increase in the production of palm oil for both exports and biodiesel production. The national policy to support the development of the palm oil sector and the national policy to promote biofuels production were approved in 2007 and 2008, respectively. They endorsed the incentives previously adopted to support the palm oil agro-industry and emphasized the strategic character of palm oil production for exports and for the biodiesel market (CONPES, 2007b; CONPES, 2008).

Intensification of governmental support to the palm oil agro-industry since the late 1990s until 2010 was embedded in a model of rural development shared by both Andrés Pastrana's and Álvaro Uribe Vélez's governments, which privileges capitalist agriculture. The 'productive alliances' and the production of biofuels were important instruments to support this model. Some passages of Andrés Pastrana's and Álvaro Uribe Vélez's national development plans presented in Box 4.1 illustrate their strong orientation towards such a conception of rural development.

Under Pastrana's and Uribe Vélez's plans, those crops that were considered with potential to be competitive in the context of an open liberalised market were given priority and were organized in production chains to enhance their commercial and economic potential. This is part of a government-sponsored project of agriculture modernisation guided by the "simple idea of production and profit" represented in the "maximization of the crop yield or profit" (Scott, 1998: 262-263). 
Box 4.1. Excerpts from the National Development Plans of Andrés Pastrana's and Álvaro Uribe Vélez's governments.

\begin{tabular}{|c|c|}
\hline $\begin{array}{l}\text { National Development Plan 1999-2002 - } \\
\text { Law 588, } 1999 \text { (art. 4.7) } \\
\text { (Andrés Pastrana’s Government) }\end{array}$ & $\begin{array}{l}\text { National Development Plan 2002-2006 - } \\
\text { Law 1151, } 2007 \text { (art. 3) } \\
\text { (Álvaro Uribe Vélez's Government) }\end{array}$ \\
\hline $\begin{array}{l}\text { Original text in Spanish (emphasis added): } \\
\text { "En cumplimiento del programa de } \\
\text { Gobierno el Ministerio de Agricultura y } \\
\text { Desarrollo Rural diseñará y pondrá en } \\
\text { marcha una política de transición para } \\
\text { elevar la productividad de las actividades } \\
\text { agropecuarias promisorias y para } \\
\text { establecer nuevas actividades que } \\
\text { reemplacen aquella en las cuales no se } \\
\text { evidencien posibilidades de mejorar su } \\
\text { competitividad en un mercado abierto. } \\
\text { Estos programas se dirigen a superar la falta } \\
\text { de preparación del sector para la apertura y } \\
\text { a orientar subsectores productivos } \\
\text { agropecuarios hacia la exportación" }\end{array}$ & $\begin{array}{l}\text { Original text in Spanish (emphasis added): } \\
\text { "El medio más eficaz para la reducción de la } \\
\text { pobreza es aumentar la capacidad de la } \\
\text { población rural para generar sus propios } \\
\text { ingresos. Para esto, dentro del marco de lo } \\
\text { propuesto por la Red de Protección Social, } \\
\text { este Gobierno promoverá: (1) el } \\
\text { fortalecimiento de los niveles de } \\
\text { empresarización de los pequeños } \\
\text { campesinos; (2) la promoción de la } \\
\text { agroindustria y el turismo rural; y (3) el } \\
\text { desarrollo de microfinanzas rurales." }\end{array}$ \\
\hline $\begin{array}{l}\text { English translation: "In compliance with the } \\
\text { Government program, the Ministry of } \\
\text { Agriculture and Rural Development will } \\
\text { design and implement a transition policy to } \\
\text { increase productivity of promising } \\
\text { agricultural activities and establish new } \\
\text { activities that replace those the } \\
\text { competitiveness of which has no possibility } \\
\text { to be improved in an open market. These } \\
\text { programs are aimed at overcoming } \\
\text { agricultural sector's lack of preparation for } \\
\text { the open market, and orienting agricultural } \\
\text { subsectors toward exports." (Emphasis } \\
\text { added). }\end{array}$ & $\begin{array}{l}\text { English translation: "The most effective way } \\
\text { to reduce poverty is to increase the capacity } \\
\text { of rural people to generate their own } \\
\text { income. To do this, within the framework } \\
\text { proposed by the Social Protection Network, } \\
\text { the Government will promote: (1) the } \\
\text { strengthening of entrepreneurial levels of } \\
\text { small farmers, (2) the promotion of } \\
\text { agroindustry and rural tourism, and (3) the } \\
\text { development of rural microfinance." } \\
\text { (Emphasis added). }\end{array}$ \\
\hline
\end{tabular}

${ }^{1}$ Refers to the document: "Plan Nacional de Desarrollo 2006-2010. Estado Comunitario: desarrollo para todos". The quote is contained in Section 3.7.3 of this document 
However, the promotion of 'high-modernist agriculture' entails a 'state simplification' (Scott, 1998) that neglects the varied and complex modes in which the rural population relates with the territories they inhabit and pursuit their livelihoods. ${ }^{8}$ For example, the integration into a single-product commodity chain is at odds with typical peasants' livelihood practices embedded in networks of social relations. Peasants usually practice agriculture in small farms that are a mosaic of crops (Forero-Álvarez, 2002) and livestock, and they often combine it with other in- or off-farm activities (fieldwork observations, Bebbington, 1999; Escobar, 2003).

As Scott points out, the 'state simplification' that 'high modern agriculture' entails "is incapable of dealing adequately with certain forms of complexity. It tends to ignore, or discount, agricultural practices that are not assimilable to its techniques" (Scott, 1998: 264). Thus, "[u]nable to effectively represent the profusion and complexity of real farms and real fields, high-modernist agriculture has often succeeded in radically simplifying those farms and fields so they can be more directly apprehended, controlled, and managed" (Scott, 1998: 262).

\subsubsection{Governmental support, structural mechanisms of access and access to land}

The palm oil agro-industry requires extensive tracts of land, so it is necessary to question:

i) how government incentives supporting development of this activity were translated into structural mechanisms of access to land, and

ii) how implementation of these incentives allowed oil palm growers and palm oil producers to gain access to large areas of land for the expansion of the palm oil frontier.

I address these issues in this section.

There is a reciprocal constitutive relation between land access and oil palm cultivation. Controlling or gaining access to land is necessary for oil palm cultivation. Oil palm growers need access to land in order to cultivate the palms. Cultivation, in turn, enables oil palm growers to extract economic benefits from land through the sale of the oil palm fresh fruit bunches (FFB) to palm oil producers. In the case of palm oil producers, they benefit from land by controlling oil palm cultivation either directly (by being simultaneously oil palm growers), and/or indirectly (through partnerships with growers or 'productive alliances').

\footnotetext{
${ }^{8}$ Scott uses the concept of 'state simplifications' to refer to processes of "rationalizing and standardizing" social and natural complexities into "legible and administratively more convenient formats", i.e. " the administrative ordering of nature and society" (Scott, 1998: 3-4).

${ }^{9}$ See Chapter 3 for more details about 'productive alliances'.
} 
By controlling cultivation, palm oil producers secure the supply of the raw material - FFB required for more profitable activities of the commodity chain such as:

i) crude palm oil extraction and distribution, and

ii) processing of crude palm oil into more value added products (food stuff, cosmetics, chemicals and biodiesel) for the national and export markets.

Thus, both oil palm growers and palm oil producers are able to benefit from land (gain or maintain access) by oil palm cultivation.

Therefore, structural mechanisms of access that enable cultivation of oil palm and ensure market access for the products resulting from different activities along the commodity chain operate as a means to gain, control or maintain land access.

Oil palm growers and palm oil providers may gain and control access to land through structural mechanisms of access, which operate in parallel to rights-based or illegal mechanisms. Oil palm cultivation requires access to capital, technology, knowledge and labour. Moreover, the ability to benefit from devoting large areas of land to this use and/or from controlling oil palm cultivation depends on access to markets for both the raw materials produced in the plantation (FFB), and the palm oil extracted from them.

The governmental support that enabled the development of the palm oil industry and the production of biodiesel between 1999 and 2010 translated into several of these structural mechanisms of access, as shown in Table 4.1. Such support took the form of credit, subsidies, fiscal incentives, public direct investment, price regulations and biodiesel blending mandates.

These instruments represented access to capital, knowledge and technology, and access to markets for the palm oil agro-industry. Most of these incentives were available not only for oil palm cultivation, and palm oil or biodiesel production, but also for other agricultural and industrial activities. However, it was the combination of them, and the way they were allocated, that constituted the 'bundle of powers' that enabled oil palm growers/palm oil producers to gain access to land for an accelerated expansion of the palm oil frontier. 
Table 4.1. Instruments of governmental support for the palm oil agro-industry along the commodity chain and the structural mechanisms of access they represent

\begin{tabular}{|c|c|c|c|}
\hline $\begin{array}{l}\text { Access Mechanism } \\
\text { Position In The } \\
\text { Commodity Chain }\end{array}$ & Access To Capital & $\begin{array}{l}\text { Access To Technology And } \\
\text { Knowledge }\end{array}$ & Access To Markets \\
\hline $\begin{array}{l}\text { Agro-Industry Crop } \\
\text { Production }\end{array}$ & $\begin{array}{l}\text { - Income tax exemption produces from oil } \\
\text { palm plantations ( } 10 \text { years) } \\
\text { - Agricultural soft credit (plantation and } \\
\text { maintenance) } \\
\text { - ICR subsidy } 1999-2007 \\
\text { - AIS-ICR subsidy } 2007-2010 \\
\text { - Subsidy interest rate soft credit (AIS-LEC) } \\
\text { - Subsidy productive alliances } \\
\text { - Guarantee agricultural credit }\end{array}$ & $\begin{array}{l}\text { - Co-funding research, development and } \\
\text { innovation (fondo concursal ciencia y } \\
\text { tecnología) } \\
\text { - Co-funding irrigation and drainage } \\
\text { (subsidy) } \\
\text { - Soft credit technical assistance } \\
\text { - Subsidy technical assistance } \\
\text { (ICR for technical assistance) }\end{array}$ & \\
\hline $\begin{array}{l}\text { Agro-Industry Crop Processing } \\
\text { (Crude Palm Oil Extraction) }\end{array}$ & $\begin{array}{l}\text { - Agro-industrial TFZ } \\
\text { - Agricultural soft credit }\end{array}$ & & $\begin{array}{l}\text { - Subsidy to cover the fee of } \\
\text { ERC. } \\
\text { - Price regulation (Price } \\
\text { Stabilization Fund) }\end{array}$ \\
\hline Industrial Transformation & $\begin{array}{l}\text { - Agro-industrial TFZ } \\
\text { - Public investment in biodiesel refineries }\end{array}$ & $\begin{array}{l}\text { - Public funding research biodiesel } \\
\text { - Plan Biocom Colciencias } \\
\text { (palm oil biodiesel) }\end{array}$ & $\begin{array}{l}\text { - Price regulation to guarantee } \\
\text { income to biodiesel producers }\end{array}$ \\
\hline Demand & & & $\begin{array}{l}\text { - Obligatory biodiesel blending } \\
\text { targets } \\
\text { - VAT and global tax exemption } \\
\text { for biodiesel }\end{array}$ \\
\hline
\end{tabular}

\section{Source: own construction.}

Acronyms:

AIS: Agro Ingreso Seguro Programme (governmental programme aimed at protecting the income of agricultural producers and improving the competitiveness of agricultural activities); ERC: Exchange Rate Risk Coverage; ICR: Rural Capitalisation Incentive; LEC: Special line of credit with subsidised interest rate; TFZ: Tax Free Zone(s);VAT: Value added tax. 


\subsubsection{Access to capital:}

Access to capital, understood as access to financial means, can take the form of credit or other financial advantages as subsidies and fiscal exemptions (Ribot and Peluso, 2003: 165). Access to capital shapes the ability to benefit from land in two ways.

Firstly, it makes possible to pay for property rights or other land tenure rights in order to gain, control or maintain direct access to land.

Secondly, it facilitates the establishment of productive activities in the land to extract economic benefits. In the case of palm oil agro-industrial activities, the benefits may be direct (income derived from selling FFB, in the case of oil palm growers) or indirect (the ability to secure supply of raw material for more profitable products, in the case of palm oil producers).

Oil palm cultivation and palm oil extraction and its industrial processing are capitalintensive activities. Capital is needed not only to pay for property rights or other forms of land tenure in order to gain access to land for oil palm cultivation. Capital is also needed to establish a plantation, maintain it for the first unproductive years (four years or more depending on the quality of soil and management practices), and exploit it. $^{10}$ Establishing/enlarging a palm oil extraction plant and a biodiesel refinery also demands large amounts of capital.

The extent of the credit, subsidies and fiscal exemptions allocated to the palm oil agroindustry between 2002 and 2010 represented a relatively substantial source of capital for oil palm cultivation and industrial processing activities (palm oil extraction and biodiesel production) by comparison with what was allocated to other agricultural sub-sectors (Table 4.2). Three types of instruments were particularly relevant, as shown in Table 4.2:

i) agricultural credit for planting and maintaining crops,

ii) the ICR subsidy, and

iii) fiscal incentives.

Table 4.2 shows the unbalanced allocation of governmental support in favour of the palm oil agro-industry as compared with other agricultural sub-sectors.

\footnotetext{
${ }^{10}$ The costs vary according to region, size of the plantation and year. According to Finagro (the national agency in charge of managing the public funds for agricultural credit) the indicative average national cost for establishing an oil palm plantation in 2008 was about USD 3,500 per hectare (Finagro, 2008).
} 
Table 4.2. Allocation of governmental support that provides access to capital for the palm oil agro-industry and other agricultural sub-sectors (2002-2010)

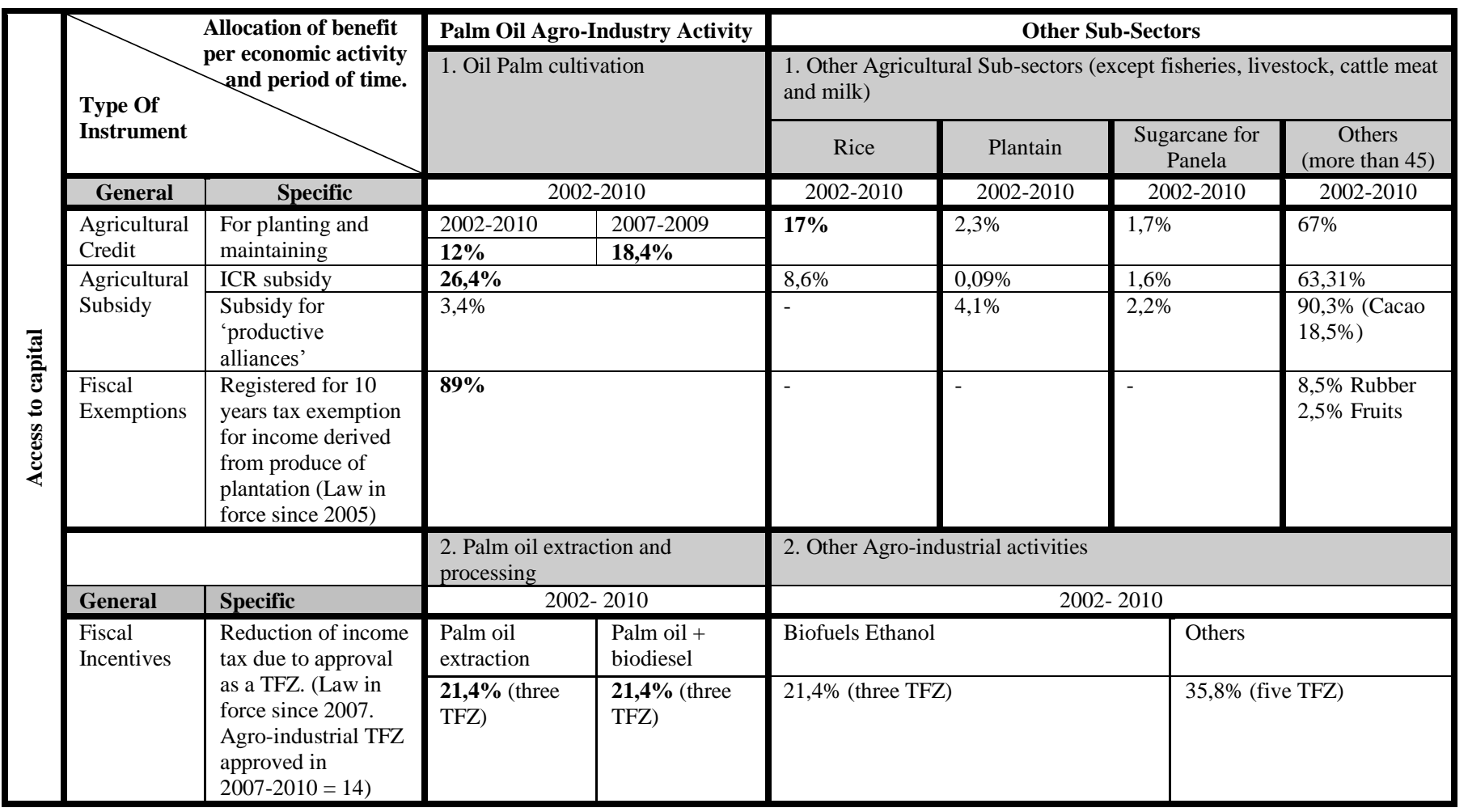

Source: own construction on the basis of CONPES, 2007b; MADR, 2010a, 2010b, 2010c; MADR, 2011; MCIT, 2013.

Acronyms: ICR: Rural Capitalisation Incentive (ICR subsidy); TFZ: Tax Free Zone(s) 
The type of activity that benefited most from income tax exemption for new or renewed late-maturing crops plantations was oil palm cultivation. The allocation of credit and ICR subsidy for oil palm cultivation was particularly large in comparison with that allocated to other crops typical of peasant agriculture, which are staple foods. Plantain and sugarcane for panela are examples of this type of crops (Forero-Álvarez, 2002). ${ }^{11}$

About $65 \%$ of the credit for planting and maintaining crops was approved between 2007 and 2009. This period coincides with the adoption and implementation of the Agro Ingreso Seguro (AIS) governmental programme. ${ }^{12}$ Also under the AIS programme during the period 2007-2009 the allocation of the ICR was higher for the palm oil industry than for other subsectors. The palm oil agro-industry was the agricultural sub-sector with the largest share in total ICR granted during the 2007-2009 period (about 18\% of the total amount granted), followed by cattle raising $(14.5 \%)$ and coffee $(11.7 \%)$ sub-sectors. The remaining $55.8 \%$ was allocated to 135 agricultural activities (CGR, 2010).

The access to capital represented in the allocation of credit, ICR and tax exemption in favour of the palm oil agro-industry was key to the accelerated expansion of oil palm cultivation between 2002 and 2010. While new cultivation increased by less than 10,000 hectares per year during the 1990 s, it increased by more than 20,000 hectares per year since 2003, as shown in Fig. 4.1. This pattern coincides with the strong governmental support received by the palm oil agro-industry since Álvaro Uribe Vélez became president of Colombia in August 2002.

Not only was allocation of governmental support to the palm oil agro-industry unbalanced in relation to other agricultural sub-sectors (Table 4.2), but it also within the agro-industry. For example, the distribution of the credit between different types of oil palm growers favoured large and medium-scale growers as shown in Fig. 4.2.

Allocation of the ICR subsidy also benefited medium and large-scale growers during the Uribe Vélez government. Reports from the National Comptroller Office show how the ICR subsidy granted during the periods 2001-2004 and 2007 went mainly to medium- and largescale agricultural producers, as well as 'productive alliances' (CGR, 2006 and 2009). ${ }^{13}$

\footnotetext{
${ }^{11}$ Panela is a country-wide consumed staple food product made of a variety of sugarcane that differs from the one used to produce processed sugar. Sugarcane for Panela is one the crops commonly cultivated by peasants (Forero-Álvarez, 2002).

${ }^{12}$ The AIS programme was adopted through the Law 1133 of 2007 that entered into effect in April, 2007. It was aimed at protecting the income of agricultural producers and improving the competitiveness of agricultural activities. However, large part of the funds of the AIS programme ended up in the hands of wealthy agro-industrials, especially oil palm growers (Revista Cambio, 2009; Lewis, 2009a).

${ }^{13}$ Neither the reports of the National Comptroller Office nor the sources of statistical information (Fedepalma, Ministry of Agriculture and Rural Development, Finagro) provide a breakdown of the
} 
Fig. 4.1. Amount of land devoted to new/renewal oil palm cultivation 1990-2012

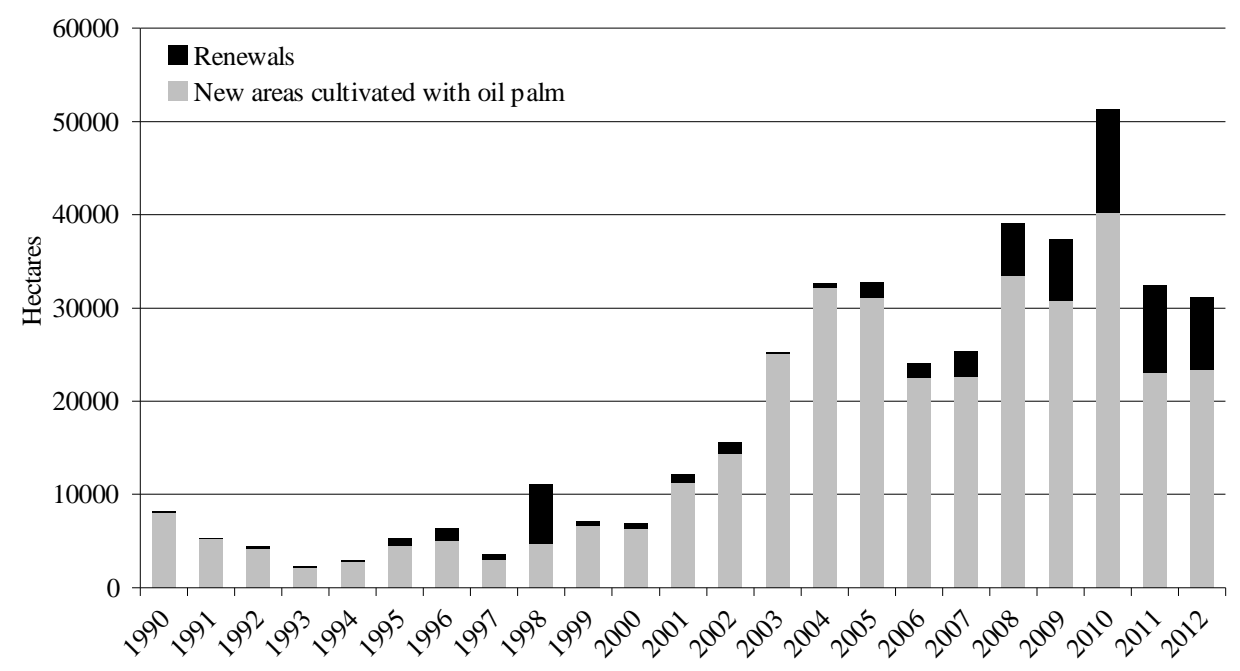

Source: SISPA (Statistics Information System of the Palm Oil Sector).

When the ICR subsidy was made applicable to cultivation and maintenance of late-maturing crops in 1999, it was available only to small-scale growers. However, Fedepalma convinced the government to extend the ICR subsidy also to medium- and large-scale growers (Mesa Dishington, 2009: 76). The argument of Fedepalma to convince the government was twofold (Mesa Dishington, 2009: 76):

i) the ICR subsidy was needed to finance the renewal of medium- and large-scale growers' plantations that had reached, or were close to reach, the end of the productive life (plantations with more than 25 years) at the end of the 1990s, which represented about $20 \%$ of the total cultivated area at the time; and

ii) giving access to the ICR subsidy to medium- and large-scale growers that entered into 'productive alliances' with small-scale growers would facilitate the expansion of oil palm cultivation.

credit/ICR received by medium- and large-scale growers and the credit/ICR received by small-scale growers organized in 'productive alliances'. They are considered as one item. In the case of Fedepalma's statistics, credit received by 'productive alliances' is calculated as a whole within the category of credit for small-scale producers. Therefore, the amount of the credit/ICR allocated to medium- and large-scale growers is probably higher than the amount reported as such. 
Fig. 4.2. Amount of Finagro (agricultural) credit for oil palm cultivation/maintenance, and distribution by type of oil palm grower 2000-2010

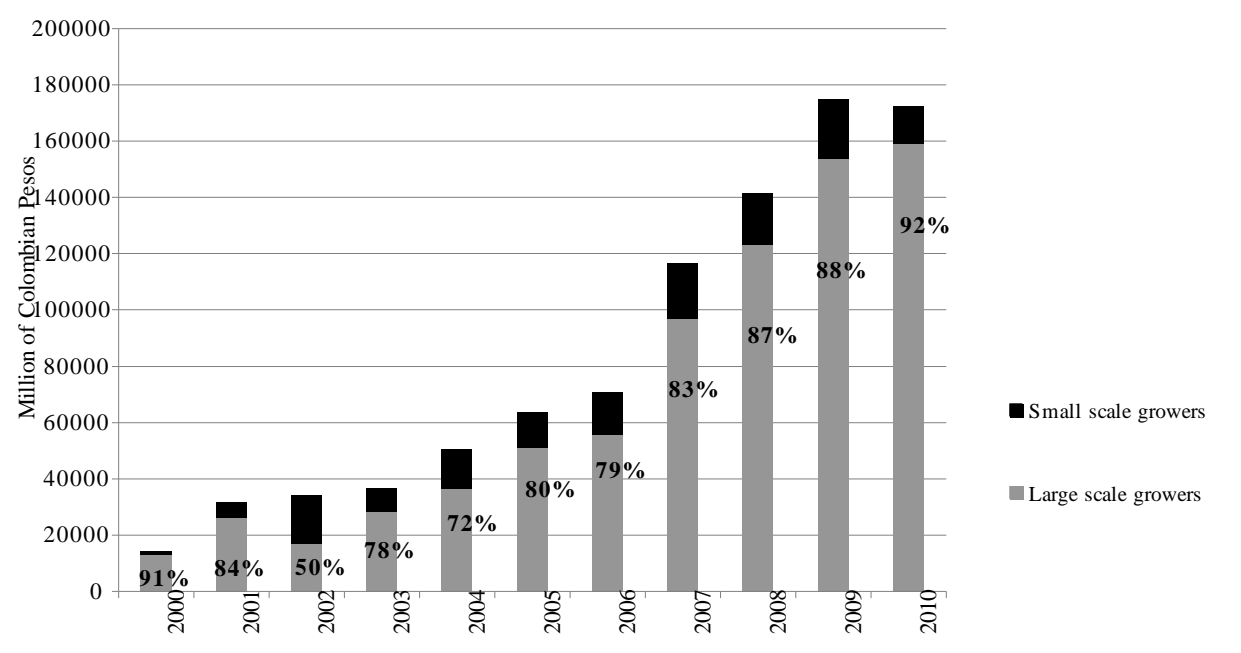

Sources: Fedepalma, 2005 and 2011a.

Note: The percentages indicate the share of the Finagro credit received by large-scale growers in the total Finagro credit granted for oil palm cultivation and maintenance.

The extension of the ICR subsidy to medium- and large-scale growers was adopted in 2000 . According to the ICR rules, the percentage of reimbursement for medium- and large-scale growers would vary depending on their involvement in 'productive alliances'. ${ }^{14}$ Large-scale growers could benefit from higher percentages of the subsidy if they were part of such associative schemes than if they were not part of them. The rules of the subsidy also established that large- and medium-scale growers must demonstrate land ownership by presenting the land deeds, while small-scale growers could benefit from the subsidy by demonstrating any kind of tenure rights through documents that prove access to land, such as rental or sharecropping agreements. Therefore, medium- and large-scale growers could benefit from entering into 'productive alliances' in two ways:

14 Resolutions 02/1999; 03/2000; 14/2001; 05/2002; 03/2005; 07/2005; 12/06; 22/07 of the Agricultural Credit National Commission (Comisión Nacional de Crédito Agropecuario). 
i) they could gain access to land indirectly (by controlling oil palm cultivation through 'productive alliances'), even in geographical areas where land acquisition was difficult or insecure due to informal land tenure practices (see Section 4.4.2.2 in Chapter 3), and

ii) they could obtain higher ICR subsidies for their own plantations.

The characteristics of the subsidy explain the unprecedented grow of oil palm cultivation under the scheme of 'productive alliances' between 2000 and 2010 (see Chapter 3).

The distribution of credit and ICR explained in this section indicates that control and maintenance of access to land by large- and medium-scale oil palm growers, either through their own plantations or through their participation in 'productive alliances', was reinforced through access to capital in the form of credit and subsidies to cultivate oil palm.

Besides the governmental support for oil palm cultivation through agricultural credit and subsidies, access to capital for the palm oil agro-industry was also strengthened through the declaration of palm oil extraction plants and biodiesel refineries as agro-industrial tax free zones (Table 4.2). This mechanism entails special fiscal treatment that includes a reduced income tax rate (15\% instead 35\%). The law that created the agro-industrial tax free zones scheme was adopted in 2007. Six out of the eleven agro-industrial tax-free zones approved between 2007 and 2010 were palm oil and palm oil-based biodiesel production plants (MCIT, 2013).

\subsubsection{Access to knowledge and technology:}

Cultivating oil palm under the agro-industrial model requires specialised knowledge and technology. The prevention and management of pests and diseases, and the improvement of soil, palm varieties, and processes are aspects that require research and development in order to enhance productivity. Access to infrastructure and technologies for irrigation and/or drainage is also required for industrial cultivation. Furthermore, processing FFB and palm oil into more value added products requires technologies for palm oil extraction and refining and biodiesel production. The government substantially supported palm oil agroindustry's access to knowledge and technology through subsidies and co-funding of research programmes during the period 2002-2010, as shown in Table 4.3.

To a large extent, research and development on oil palm cultivation, and on palm oil extraction and processing are carried out by Cenipalma - Oil Palm Research Centre. ${ }^{15}$ Between 2002 and 2010, the government contributed to Cenipalma's activities by co-

\footnotetext{
${ }^{15}$ Cenipalma (Corporación Centro de Investigación en Palma de Aceite) is the research centre of the palm oil agro-industry. It was created in 1991 as a result of a decision made by the oil palm growers and palm oil producers belonging to Fedepalma during the XVII Oil Palm Growers National Meeting.
} 
funding both research projects and the establishment of an experimental plantation inaugurated in 2004 (Mesa Dishington, 2009: 93).

Furthermore, the government agency for science, technology and innovation - Colciencias - was given the responsibility for coordinating publicly funded research projects on palm oil and palm oil-based biodiesel under a governmental programme identified as 'Biocom'.

The palm oil sector as a whole received governmental support for the development of knowledge and technology. Oil palm growers and palm oil producers also received subsidies and fiscal incentives that supported access to technology and knowledge. For example, palm oil growers benefited from subsidies for irrigation and drainage and for technical assistance, which were part of the AIS programme (Table 4.3).

Table 4.3 Allocation of access to knowledge and technology governmental support for the palm oil agro-industry

\begin{tabular}{|c|c|c|c|c|}
\hline \multirow{11}{*}{ 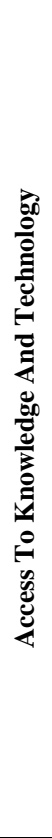 } & \multirow[b]{2}{*}{$\begin{array}{l}\text { Type of } \\
\text { Instrument }\end{array}$} & \multirow{2}{*}{$\begin{array}{c}\begin{array}{c}\text { Allocation of benefit } \\
\text { per economic activity } \\
\text { and period of time. }\end{array} \\
\end{array}$} & \multicolumn{2}{|c|}{ Palm Oil Agro-Industry Activity } \\
\hline & & & 1. Oil Palm cultivat & \\
\hline & General & Specific & \multicolumn{2}{|c|}{$2002-2010$} \\
\hline & $\begin{array}{l}\text { Co-funding } \\
\text { research and } \\
\text { development }\end{array}$ & $\begin{array}{l}\text { MADR support for science } \\
\& \text { technology }\end{array}$ & \multicolumn{2}{|l|}{$2,3 \%$} \\
\hline & $\begin{array}{l}\text { Agricultural } \\
\text { subsidy }\end{array}$ & $\begin{array}{l}\text { Subsidy technical assistance } \\
\text { (AIS 2007-2009) }\end{array}$ & \multicolumn{2}{|l|}{$0,03 \%$} \\
\hline & & $\begin{array}{l}\text { Subsidy irrigation and } \\
\text { drainage (AIS 2007-2009) }\end{array}$ & \multicolumn{2}{|c|}{$\begin{array}{l}\mathbf{2 0 \%}(2007-2008) \\
\text { Allocation of funds in } 2009 \text { was suspended }\end{array}$} \\
\hline & & & \multicolumn{2}{|c|}{ 2. Palm oil extraction and processing } \\
\hline & General & Specific & \multicolumn{2}{|c|}{$2002-2010$} \\
\hline & \multirow[t]{2}{*}{$\begin{array}{l}\text { Fiscal } \\
\text { exemptions }\end{array}$} & \multirow{2}{*}{$\begin{array}{l}\text { Reduction VAT due to the } \\
\text { approval as TFZ (Law in } \\
\text { force since } 2007 \text {. } \\
\text { Agroindustrial TFZ } \\
\text { approved in } \\
2007-2010=14 \text { ) }\end{array}$} & Palm oil extraction & Palm oil biodiesel \\
\hline & & & $\begin{array}{l}\mathbf{2 1 , 4 \%} \\
\text { (three TFZ) }\end{array}$ & $\begin{array}{l}\mathbf{2 1 , 4 \%} \\
\text { (three TFZ) }\end{array}$ \\
\hline & $\begin{array}{l}\text { Co-funding } \\
\text { research and } \\
\text { development }\end{array}$ & $\begin{array}{l}\text { MADR support for research } \\
\text { on biodiesel }\end{array}$ & & COP\$ 3272 Million \\
\hline
\end{tabular}

Source: own construction on the basis of CGR, 2010; CONPES, 2007b; MADR, 2010a, 2010b, 2010c; MCIT, 2013.

Acronyms: MADR: Ministry of Agriculture and Rural Development; AIS: Agro Ingreso

Seguro Programme; TFZ: Tax Free Zone(s); VAT: Value added tax 
In 2009 journalists unveiled a list of companies and individuals of local and national elites that benefited from AIS programme subsidies. The list revealed that a large amount of subsidies for projects of irrigation and drainage were allocated to large-scale oil palm growers/palm oil producers, a number of which are family business of local and national elites. For example, eight families of large-scale oil palm growers received about COP 20,000 million (about USD 9.7 million) in AIS subsidies for irrigation and drainage between 2007 and 2009 (Coronell, 2009a; Revista Cambio, 2009; Lewis, 2009a). However, the percentage of the technical assistance subsidy that was allocated to oil palm cultivation which was applicable only to small-scale growers - was relatively small (see Table 4.3).

Lastly, the reduction in the value added tax that applies to goods bought by companies constituted as agro-industrial tax free zones also facilitated access to technology to palm oil producers that have established palm oil extraction plants and/or biodiesel refineries under this scheme.

\subsubsection{Access to Markets:}

As Ribot and Peluso (2003) point out, the ability to benefit from a resource in commercial terms may depend more on access to markets than on tenure rights. Price regulations aimed at ensuring producers' or distributors' profitability further contribute to increase the benefits obtained from access to markets (Ribot and Peluso, 2003: 166-167).

Obtaining economic benefits from the control of oil palm cultivation depends on access to markets to sell the FFB harvested and the palm oil extracted. Palm oil producers benefit from the use of land for oil palm cultivation, even if they don't own the land but control its use through 'productive alliances'. This is because they have the ability to allocate value added products resulting from processing FFB to different markets (national or international markets for food, cosmetics, chemicals or biofuels).

This ability has been enhanced through a mechanism for price stabilisation - the palm oil price stabilisation fund - authorized by the government in 1996 and administrated by Fedepalma. Fedepalma defines the methodology to establish a reference price of palm oil for the export market and for the level of compensation to be made through the fund. Thus, this mechanism operates as a sort of price regulation that "optimizes sales revenues for producers and guarantees that all of them will participate under equal price conditions in both the national and foreign markets". ${ }^{16}$ Moreover, since 2006 the government provides subsidies to exporting agro-industries to obtain exchange rate risk coverage. Several palm oil producers benefited from these subsidies as shown in Table 4.5 in Section 4.3.3.3 below.

\footnotetext{
${ }^{16} \mathrm{http} / / /$ portal.fedepalma.org//fund.htm (Accessed August 22, 2013 ).
} 
The policies and instruments adopted by Álvaro Uribe Vélez's government to implement a national biofuels strategy ensured market access for palm oil producers and the oil palm growers that supply them with FFB. A key instrument was the national biodiesel blending mandate (see Table 4.4). It enlarged the national market for palm oil, so stimulating oil palm cultivation.

Table 4.4. Implementation of the biodiesel blending mandate in Colombia

\begin{tabular}{|c|l|l|l|l|}
\hline Year & \multicolumn{1}{|c|}{$\mathbf{2 0 0 4}$} & \multicolumn{1}{c|}{ Jan 2008 } & \multicolumn{1}{c|}{ 2008-2010 } & \multicolumn{1}{c|}{ Sept 2010 } \\
\hline $\begin{array}{c}\text { Adoption of the } \\
\text { biodiesel blending } \\
\text { mandate }\end{array}$ & $\begin{array}{l}\text { General mandate } \\
\text { (Law 934, Dec } \\
2004)\end{array}$ & $\begin{array}{l}5 \% \text { biodiesel } \\
\text { blending target in } \\
\text { Atlantic coast } \\
\text { region }\end{array}$ & $\begin{array}{l}\text { Gradual increase } \\
\text { in blending targets } \\
\text { and number of } \\
\text { regions }\end{array}$ & $\begin{array}{l}10 \% \text { biodiesel } \\
\text { blending target in the } \\
\text { entire country (with } \\
\text { the exception of a } \\
\text { few municipalities) }\end{array}$ \\
\hline
\end{tabular}

Source: own construction on the basis of García Romero and Calderón Etter, 2012.

Besides the blending mandates, the government regulates the price of biodiesel to ensure a minimum profitability for the biodiesel producer. Since biodiesel producers are at the same time palm oil producers (see Chapter 3), the formula is designed to ensure that directing palm oil for biodiesel production is more profitable than directing it to supply other markets. In this way, both the achievement of the blending targets and profitability for palm oil/biodiesel producers are guaranteed.

The combination of these two interventions (blending targets and price regulation) created an increasing secure and profitable national market for palm oil, so providing the palm oil agro-industry with an unique advantage in terms of access to market, especially for producers and growers that are vertically integrated. This newly created biodiesel market was key to the contemporary expansion of the palm oil frontier. Since 2008 - when the biodiesel blending targets started to be implemented - the national biodiesel market has increasingly absorbed palm oil production, as shown in Chapter 3. In 2010, about half of the palm oil consumption was for biodiesel production.

\subsubsection{Governmental support and access to authority}

Section 4.3.2 presented evidence to show that the palm oil agro-industry has been privileged by the government - in particular by Álvaro Uribe Vélez's government - in a way that individuals and organization interested in oil palm cultivation, as well as already established oil palm growers and palm oil producers substantially benefited from governmental support. In this section, I explore the relational 'bundles of power' that shaped these actors' ability to influence policy-making and implementation. 
The key relational mechanism in the case of governmental support to the palm oil agroindustry in Colombia is what Ribot and Peluso describe as 'access to authority'. The special treatment conferred to the palm oil agro-industry between 1998 and 2010 was based on a privileged access to government that permitted the agro-industry to influence policy-making and implementation. As Ribot and Peluso point out, "privileged access to the individuals or institutions with the authority to make and implement laws can strongly influence who benefits from the resource in question" (Ribot and Peluso, 2003: 170). This privileged access corresponds to what Ribot calls 'selective access to the state' (Ribot, 1998: 334). In the case of the palm oil agro-industry in Colombia, 'selective access to the state' has flowed through three interrelated channels detailed below.

\subsubsection{Agro-industry strong institutional organization:}

The first channel of privileged access is a strong institutional organization through which oil palm growers and palm oil producers speak as one to the government. Palm oil producers and growers are organized at national level through the National Federation of Oil Palm Growers - Fedepalma. By 2012, palm oil producers and oil palm growers affiliated to Fedepalma represented more than $85 \%$ of the installed capacity of oil production companies in the country, and about $47 \%$ of the planted area (IADB, 2012).

Furthermore, because almost all of the biodiesel refineries in the country are partially or totally owned by palm oil producers (see Chapter 3), Fedepalma is a member of the Biofuels National Federation (Fedebiocombustibles). The Executive President of Fedepalma and some palm oil producers are members of Fedebiocombustibles's board of directors.

Fedepalma has had substantial influence in the adoption of governmental incentives and policies that have supported the development of both the palm-oil agro-industry and the biofuels sector. Fedepalma's ability to influence policy-making has come from the operation of two mutually reinforcing mechanisms.

First, because of its strong organization and capacity of representation (it brings together the majority of the oil palm growers and palm oil producers of the country) Fedepalma appears to the government as a legitimate and important stakeholder as regards policies and decisions concerning the agro-industry.

Second, as the palm oil industry has benefited from policy-making, it has grown and acquired more importance for the agricultural sector and the national economy (MADR, 2005). In so doing, Fedepalma's political power has strengthened so that its ability to 
advance the interests of oil palm growers and palm oil producers at the national level has been reinforced

The brief description of Fedepalma's activities posted in its English website illustrates how this organization has worked to gain 'selective access' to the government in order to influence national policies:

"Oil palm growers have one of the most dynamic industrial associations in the Colombian agricultural sector: the National Federation of Oil Palm Growers, Fedepalma. Its activities have been decisive in securing a solid position for the agribusiness in this country... Until the 1980's Fedepalma concentrated much of its efforts on seeking agreements with successive governments regarding the conditions necessary to encourage oil palm production and protect the marketing of its products. In the 1990's, the expansion and consolidation of the industry required the Federation to promote measures to ensure that the production of palm oil would be more competitive and that the conditions of sales at home and abroad would be more defined. As a result of those efforts, the industry today has a strong infrastructure which includes bodies engaged in research, marketing and oil palm development ${ }^{\text {,17 }}$

Among Fedepalma's achievements are the establishment of the Price Stabilisation Fund in 1996 and the applicability of the ICR to the planting and maintaining of late-maturing crops in 1999. Mesa Dishington (2009) provides a detailed historical account of Fedepalma's efforts to influence policy-making and its accomplishments. However, it was during Álvaro Uribe Vélez's government when Fedepalma achieved the strongest governmental support in the history of the palm oil agro-industry. What allowed Fedepalma to have such a strong influence on policy making and implementation during Uribe Vélez's government was a convergence of interests. Due to palm oil suitability for biodiesel production, the interest of Álvaro Uribe Vélez in making of Colombia a biofuel producer became an opportunity for Fedepalma to strongly place the interests of the agro-industry in the public agenda. The following words of Fedepalma's executive president illustrate this argument:

${ }^{17}$ http://portal.fedepalma.org/fede_eng.htm (Accessed May 15, 2013). 
Original in Spanish

"El doctor Álvaro Uribe Vélez llegó a la Presidencia de la República en 2002, con la idea y la decisión de promover los biocombustibles. Asumió esta tarea como uno de los ejes estratégicos de su política agropecuaria y abrió unas posibilidades de desarrollo sectorial que los palmeros no habíamos vislumbrado para el corto ni el mediano plazo....el interés manifiesto del Gobierno de promover la producción de biocombustibles nos mostró una ventana de oportunidad para crecer el negocio." (Mesa Dishington, 2009: 111)
English own translation:

"Doctor Álvaro Uribe Vélez came to the presidency in 2002 with the idea and the decision to promote biofuels. He undertook this task as one of the strategic components of his agricultural policy, and opened up possibilities of development for the palm oil sector that we had not foreseen for the short or the medium term... the explicit interest of the Government in promoting biofuels production provided us as with a window of opportunity to make the business grow."

As a consequence, Fedepalma contributed to the formulation of the law that contains both the general biofuel mandate, and the ten-year tax exemption for the income derived from oil palm cultivation (Law 939, 2004). It also contributed to the formulation of the policy to promote biofuels production in Colombia adopted in 2008. Fedepalma also provided the government with the guidelines for what became the public policy to support the development of the palm oil sector in 2007 (Mesa Dishington, 2009). The fruits of this work are evident in the accelerated expansion of oil palm cultivation and the development of a biodiesel national market between 2002 and 2010.

\subsubsection{Flow of experts:}

The second channel of privileged access is a flow of experts that have worked for the government as public officials or consultants and moved to work for, or advise, Fedepalma (or other entities connected to it as Cenipalma), and vice versa. Fig. 4.3 illustrates a flow of movements between Fedepalma and governmental agencies/positions (shaded circles) of key consultants and managers that worked for Fedepalma in the period 2000-2013. The letters ' $\mathrm{A}$ ' to ' $\mathrm{G}$ ' in Fig. 4.3 represent these consultants and managers. The figure is a graphic representation of Table C.1 in Appendix C, which contains the names of the individuals represented with the letters from ' $A$ ' to ' $G$ ', and the description and period of the positions occupied by such individuals in each organization or agency. 
Fedepalma welcomes experts that worked for the government because:

i) the work they did and the knowledge they acquired during their period in the government are valuable for realising the interests of the palm oil agro-industry, and

ii) they can help Fedepalma to influence policy-making through the network of acquaintances within the government they remain connected with.

Likewise, when experts move from working for Fedepalma to work for the government they become direct contact points within the government through whom the interests of the agro-industry can be placed on the public agenda. This is the case of individuals 'A' and ' $\mathrm{D}$ ' (Fig. 4.3), who played a key role in the policy-making and implementation that favoured the palm oil agro-industry between 1998 and 2010. Individual 'A' played a substantial role in the promotion of palm-oil-based biodiesel from his position in the National Planning Department (DNP) as coordinator of the sustainable biofuels development programme during Álvaro Uribe Vélez's second presidential period.

Fig. 4.3. Flow of individuals moving to work from government to Fedepalma and vice versa.

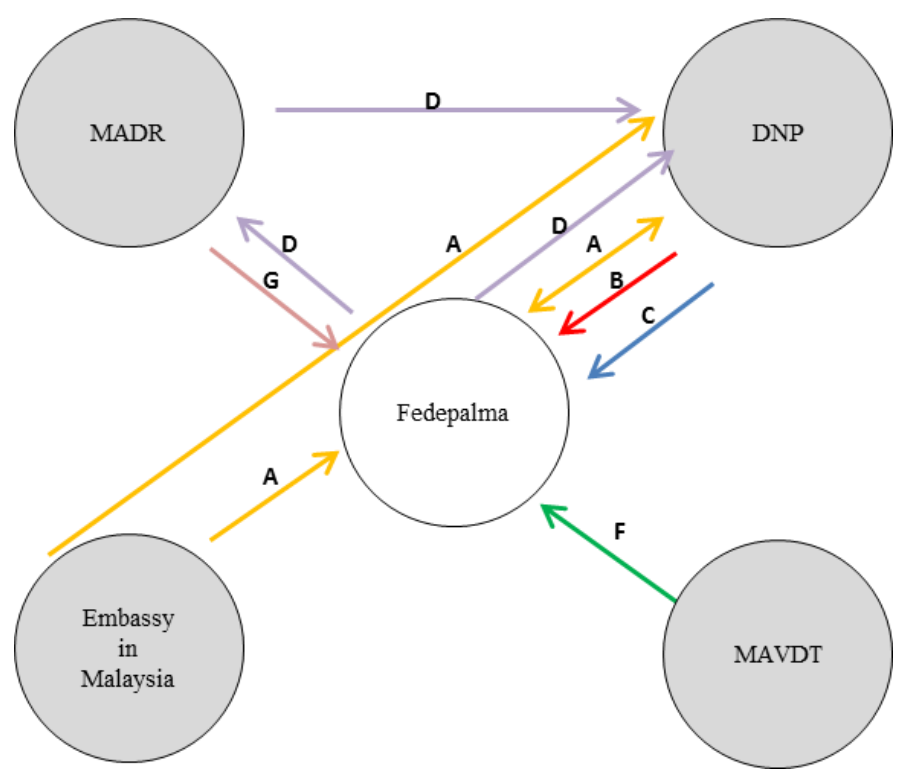

Source: own construction.

Acronyms:

DNP (National Planning Department)

MADR (Ministry of Agriculture and Rural Development)

MAVDT (Ministry of Environment, Housing and Territorial Development). 
However, the relations of individual ' $A$ ' with the palm oil sector dated from several years before. As the Ambassador of Colombia to Malaysia between 1996-2002, he was key to the establishment of cooperation relations between Colombian and Malaysia focused in the palm oil sector. In 1999, he facilitated a visit of a mission from Colombia to Malaysia in order to strengthen connections between both countries' palm oil sectors. The mission included delegates from the government and Fedepalma, and was led by the Ministry of Agriculture and Rural Development (MADR) at the time, Carlos Murgas (who also owned oil palm plantations as explained in Section 4.3.3.3 below). As ambassador, individual 'A' also signed a memorandum of understanding with the Malaysian General Secretary of Primary Industries for scientific and technical cooperation in the field of palm oil production in Colombia. ${ }^{18}$ Moreover, after occupying the position of Ambassador to Malaysia, individual ' $\mathrm{A}$ ' was commissioned by Fedepalma to carry out a study about the technical and economic feasibility of palm oil-based biodiesel in 2004.

Individual ' $\mathrm{D}$ ' had a history of relations with the palm oil agro-industry similar to the history of individual 'A'. After having worked for Fedepalma as economic director, he became the director of agricultural policy at the Ministry of Agriculture and Rural Development (2002-2004). From his position in the Ministry he was crucial to the adoption of incentives to support late-maturing crops such as palm oil.

This flow of experts was further coupled with an agreement signed in 2006 between Fedepalma/Cenipalma, WWF (World Wildlife Fund)-Colombia and an institute connected to the Ministry of Environment as its research branch (the Alexander Von Humboldt Institute for Research on Biological Resources - IAvH). The objective of the agreement was that these organizations worked together on mechanisms of environmental planning for the palm oil sector.

Although the cooperative character of the contract can be seen a positive step, it facilitated the formation of a small and closed circle of experts that connects Fedepalma with the Ministries of Agriculture and Environment. This conclusion emerged from various interviews during the fieldwork in which the same persons were constantly referred to me as 'key informants'. Each of these persons has worked as employee or advisor for at least two of these entities: the Ministry of Agriculture and Rural Development (MADR), the IAvH, the Ministry of Environment, Housing and Territorial Development (MAVDT) and

\footnotetext{
${ }^{18}$ The memorandum became an agreement for economic, technical, scientific and cultural cooperation between Colombia and Malaysia approved through the Law 895, 2004.
} 
WWF; and each of them has been involved in projects resulting from the cooperation between governmental agencies and Fedepalma. ${ }^{19}$

\subsubsection{Family ties and political financing:}

Palm oil producers, oil palm growers and executives working for the palm oil agro-industry not only have access to governmental circles through Fedepalma. Some of them have personal relations with governmental agencies, public officials, ministries, and even with the President, mediated by family ties or support for political campaigns. In some cases the owners of palm oil companies or their relatives have been part of the government themselves and some of them have financed political campaigns either personally or through their companies (Marín, 2009). Table 4.5 illustrates this type of relations with Uribe Vélez's government and the benefits received by specific palm oil growers/palm oil producers during such government. This table is a summary of the more detailed Table C.2 in Appendix C.

The cases of three of the largest oil palm growers/palm oil producers - Oleoflores group, DAABON Group and Indupalma - are illustrative of how the relations of palm oil producers/oil palm growers with the government, especially with Uribe Vélez's government, have been mediated by family ties or support for political campaigns.

Carlos Murgas is the owner of one of the largest business groups in the palm oil agroindustry in Colombia - Grupo Empresarial Oleoflores. He has been president and member of Fedepalma's board of directors for several years, and was Minister of Agriculture between 1998 and 1999. ${ }^{20}$ It was during his time at the Ministry that the ICR was extended to late-maturing crops. Moreover, being minister, he designed the government programme to promote the 'productive alliances' (Mesa Dishington, 2009), which is the business model that Grupo Empresarial Oleoflores applies in order to expand oil palm cultivation. Murgas' business group controls the largest amount of land cultivated with oil palm under the scheme of 'productive alliances' in the country, i.e. about 25.000 hectares by $2011 .{ }^{21}$ Even after his period in the Ministry, Carlos Murgas continued to have access to governmental circles. The presence of the President Álvaro Uribe Vélez in the opening of Oleoflores' palm oil-based biodiesel refinery in 2008 is illustrative.

\footnotetext{
${ }^{19}$ The structure and named of the MAVDR were changed in 2011. The functions related to housing were transferred to a new Ministry of Housing, and the name of the MAVDR was changed as Ministry of Environment and Sustainable Development.

${ }^{20}$ Carlos Murgas is currently an honorary member of Fedepalma's board of directors.

${ }^{21} \mathrm{http}: / /$ www.oleoflores.com/alianzas.html\#content12 (Accessed May 31, 2013).
} 
Table 4.5. Families, individuals and organizations in the palm oil agro-industry connected with the government and beneficiaries from governmental support

\begin{tabular}{|c|c|c|c|c|c|c|c|c|c|}
\hline \multicolumn{2}{|c|}{$\begin{array}{c}\text { Families/Individuals/Organizations in phe Palm } \\
\text { oil agro-industry }\end{array}$} & \multirow{4}{*}{$\begin{array}{l}\text { Personal/family ties } \\
\text { with the government } \\
\text { (all during Álvaro Uribe } \\
\text { Vélez's government } \\
\text { except Carlos Murgas) }\end{array}$} & \multicolumn{3}{|c|}{$\begin{array}{l}\text { Political support to the government } \\
\text { (economic support or advisory roles) }\end{array}$} & \multicolumn{4}{|c|}{ Benefits received during Álvaro Uribe Vélez's government } \\
\hline \multirow[t]{3}{*}{ Name } & \multirow{3}{*}{\begin{tabular}{|l|} 
Relation with palm oil \\
agro-industry \\
Acronyms: \\
Large-scale $=$ LS \\
Oil palm grower $=\mathrm{G}$ \\
Palm oil producer $=\mathrm{P}$ \\
Biodiesel producer $=\mathrm{B}$
\end{tabular}} & & \multirow{3}{*}{$\begin{array}{l}\text { Presidential } \\
\text { campaign } \\
\text { Álvaro } \\
\text { Uribe } \\
\text { Vélez } 2002\end{array}$} & \multirow{3}{*}{$\begin{array}{l}\text { Presidential } \\
\text { campaign } \\
\text { Álvaro Uribe } \\
\text { Vélez } 2006\end{array}$} & \multirow{3}{*}{$\begin{array}{l}\text { Campaign } \\
\text { referendum } \\
\text { 2nd } \\
\text { reelection } \\
\text { Álvaro Uribe } \\
\text { Vélez }\end{array}$} & \multicolumn{3}{|c|}{ Direct } & \multirow{3}{*}{$\begin{array}{c}\text { Credit/ } \\
\text { Subsidies for } \\
\text { 'Productive } \\
\text { alliances' connected } \\
\text { with them. }\end{array}$} \\
\hline & & & & & & \multirow{2}{*}{$\begin{array}{c}\text { Subsidies } \\
\text { under AIS } \\
\text { programme } \\
(2007-2009)\end{array}$} & \multicolumn{2}{|c|}{ Others } & \\
\hline & & & & & & & $\begin{array}{l}\text { Subsidies } \\
2002-2007\end{array}$ & TFZ & \\
\hline $\begin{array}{l}\text { Family Murgas Dávila } \\
\text { (Oleoflores business } \\
\text { group) }\end{array}$ & LS G, P, B & $\begin{array}{l}\text { Carlos Murgas (Ministry } \\
\text { Agriculture 1998-1999 } \\
\text { Andrés Pastrana’s } \\
\text { government) }\end{array}$ & $\checkmark$ & & $\checkmark$ & $\begin{array}{l}\text { ICR } \\
\text { LEC }\end{array}$ & ERC & $\checkmark$ & $\checkmark$ \\
\hline $\begin{array}{l}\text { Family Dávila Abondano } \\
\text { (DAABON business } \\
\text { Group: C.I Tequendama) }\end{array}$ & LS G, P, B & $\checkmark$ & $\checkmark$ & & $\checkmark$ & $\mathrm{I} \& \mathrm{D}$ & ERC & $\checkmark$ & $\checkmark$ \\
\hline $\begin{array}{l}\text { Family Eder } \\
\text { (Manuelita business } \\
\text { group: Aceites Manuelita } \\
\text { s.a.) }\end{array}$ & LS G, P, B & $\checkmark$ & $\checkmark$ & $\checkmark$ & $\checkmark$ & ERC & ERC & $\checkmark$ & \\
\hline \begin{tabular}{l|l|}
$\begin{array}{l}\text { Family Gutt Haime } \\
\text { (Indupalma) }\end{array}$ \\
\end{tabular} & LS G, P & $\checkmark$ & $\checkmark$ & $\checkmark$ & & & & $\checkmark$ & $\checkmark$ \\
\hline $\begin{array}{l}\text { Family Lacouture Pinedo } \\
\text { (C.I El Roble) }\end{array}$ & LS G, P & $\checkmark$ & $\checkmark$ & & & $\mathrm{I} \& \mathrm{D}$ & ERC & & $\checkmark$ \\
\hline $\begin{array}{l}\text { Family Vives Lacouture } \\
\text { (Extractora Frupalma s.a) }\end{array}$ & LS G, P & & $\checkmark$. & & & $\begin{array}{l}\text { I\&D } \\
\text { ERC }\end{array}$ & ERC & & $\checkmark$ \\
\hline Family Solano Tribín & LS G, P & & & & $\checkmark$ & $I \& D$ & & & \\
\hline $\begin{array}{l}\text { Family Mattos Liñán } \\
\text { (Palmagro s.a.) }\end{array}$ & LS G, P & & $\checkmark$ & & & LEC & & & \\
\hline $\begin{array}{l}\text { Family Dangond } \\
\text { Lacouture } \\
\text { (Palmas Oleaginosas de } \\
\text { Cascara) }\end{array}$ & LS G, P & & $\checkmark$ & & & $I \& D$ & ERC & & \\
\hline
\end{tabular}




\begin{tabular}{|c|c|c|c|c|c|c|c|c|}
\hline $\begin{array}{l}\text { Family de Hart Pinto } \\
\text { (Agroince) }\end{array}$ & LS G, P, B & $\checkmark$ & $\checkmark$ & & & ERC & $\checkmark$ & \\
\hline Palmas del Cesar s.a. & LS G, P, B & & $\checkmark$ & & ERC & ERC & $\checkmark$ & $\checkmark$ \\
\hline $\begin{array}{l}\text { Palmas Oleaginosas } \\
\text { Bucarelia s.a. }\end{array}$ & LS G, P, B & & $\checkmark$ & & ERC & ERC & $\checkmark$ & \\
\hline $\begin{array}{l}\text { Palmeras de Puerto } \\
\text { Wilches }\end{array}$ & LS G, P, B & & $\checkmark$ & & & ERC & $\checkmark$ & \\
\hline $\begin{array}{l}\text { Family Espinosa } \\
\text { (Espinosa business } \\
\text { group: Palmar del } \\
\text { Oriente s.a and Palmas } \\
\text { de Tumaco s.a.) }\end{array}$ & LS G, P & & $\checkmark$ & & ERC & ERC & & \\
\hline $\begin{array}{l}\text { Family Dávila Fernández } \\
\text { de Soto }\end{array}$ & LS G, P & & $\checkmark$ & & $\begin{array}{l}\text { I\&D } \\
\text { ERC }\end{array}$ & ERC & & \\
\hline Palmasol s.a. & LS G, P, B & & $\checkmark$ & & ERC & ERC & $\checkmark$ & \\
\hline $\begin{array}{l}\text { Agroindustria el Conuco } \\
\text { s.a. }\end{array}$ & LS G & $\checkmark$ & & & ICR & & & \\
\hline $\begin{array}{l}\text { Family } \\
\text { Zúñiga Caballero } \\
\text { (Urapalma, Palmura, } \\
\text { Extractora Bajirá, } \\
\text { Gradesa) }\end{array}$ & $\begin{array}{ll}\text { LS G } \\
\end{array}$ & $\checkmark$ & & & & ICR & & \\
\hline Jens Mesa Dishington & $\begin{array}{l}\text { Executive president } \\
\text { Fedepalma }\end{array}$ & $\checkmark$ & $\checkmark$ & $\checkmark$ & & & & \\
\hline
\end{tabular}

Source: own construction. See data sources in Appendix C - Table C.2.

Acronyms: AIS: Agro Ingreso Seguro Programme; LEC: Special line of credit with subsidised interest rate; ICR: Rural Capitalisation Incentive I\&D: Subsidy for Irrigation and Drainage; ERC: Subsidy for Exchange Rate Risk Coverage; TFZ: Tax Free Zone(s). 
Oleoflores contributed to financing Álvaro Uribe Vélez's first presidential campaign, and gave funds to an organization that was campaigning for a referendum aimed at reforming the Constitution in order to allow Álvaro Uribe Vélez to run for a third presidential period (Lewis, 2009b). Furthermore, Oleoflores business group's affiliate companies also obtained benefits from the AIS programme (Lewis, 2009b).

Other large oil palm growers/palm oil producers that maintained close relations with Uribe Vélez's government were the DAABON Group and Indupalma.

The DAABON Group belongs to the Dávila-Abondano family, one of the wealthiest families of the north region of Colombia. One of its members made a donation to the first presidential campaign of Uribe Vélez, and two of DAABON's affiliates gave funds to the organization that was campaigning for the referendum mentioned above (Coronell, 2009b; Lewis, 2009b). As in the case of Oleoflores, Álvaro Uribe Vélez also attended the opening of DAABON's biodiesel refinery in 2009, and DAABON Group was beneficiary of subsidies under the AIS programme in 2008 and 2009 (Coronell, 2009a). ${ }^{22}$

Indupalma belongs to the Gutt Haime family's business group. Two members of this family contributed to financing Álvaro Uribe Vélez's second presidential campaign (CdR, 2010). During Uribe Vélez's government, three projects of small-scale growers allied with Indupalma which supply FFB to Indupalma's palm oil extraction plants received soft agricultural credit for the establishment of oil palm plantations that amount to about 4,000 hectares (Indupalma, 2011). Furthermore, Indupalma was chosen by the Ministry of Agriculture to be the operator of a project in land assigned by the government to internally displaced people under the condition that the beneficiaries must cultivate oil palm (see Case 3 in Section 5.4.2, Chapter 5).

Both DAABON and Indupalma also benefited from the law on agro-industrial tax free zones approved during Uribe Vélez's government. DAABON's biodiesel refinery and Indupalma's new palm oil extraction plant were approved as tax free zones in 2007 and 2010 , respectively.

\subsection{Conclusions}

In this chapter I aim to elucidate how governmental support to promote sector-specific extractive activities influences who gains, maintains or controls access to resources and how.

\footnotetext{
${ }^{22}$ http://web.presidencia.gov.co/sne/2007/julio/08/04082007.htm (Accesed August 3, 2012).
} 
On the basis of Ribot and Peluso's theory of access (2003), I explore how governmental support translates into structural and relational mechanisms that enable access to resources to expand extraction frontiers. I do so by drawing on the case of governmental support to the palm oil agro-industry in Colombia.

The "theory of access" provides the conceptual and analytical tools to empirically investigate the structural and relational mechanisms of access at play when extractive activities are strongly supported by the government. It is possible through access analysis to demonstrate the role that governmental support plays in the political economy of 'accumulation by dispossession' (Harvey, 2003) connected with the expansion of extraction frontiers. Since such expansion is often at the basis of socio-environmental conflicts, this type of access analysis contributes to deepen the understanding of the political economy underlying resource access struggles.

In the case of Colombia, an accelerated expansion of the palm oil frontier between 2000 and 2010 is at the basis of socio-environmental conflicts over access to land in regions of oil palm cultivation (see Chapters 3 and 5). Governmental support to the palm oil agro-industry since the late 1990s, but especially between 2002-2010, was key to the expansion of the frontier. Governmental support worked through structural and relational mechanisms of access that constituted the 'bundle of powers' (Ribot and Peluso, 2003: 158) though which oil palm growers/ palm oil producers gained access to large extensions of land for oil palm cultivation.

The key relational mechanism of access was the 'access to authority' in the form of 'selective access to the state' through different channels:

i) a strong institutional organization through the National Federation of Oil Palm Growers - Fedepalma - that worked on influencing policy making on behalf of the majority of palm oil palm growers/ palm oil producers;

ii) a flow of experts between Fedepalma and governmental agencies that facilitated Fedepalma's influence in governmental spheres; and

iii) relations with the government mediated by family ties and political support.

Furthermore, palm growers/ palm oil producers wisely took advantage of the convergence between their interests and the interest of Álvaro Uribe Vélez's (Colombian President 20022010) in making of Colombia a major palm oil-based biodiesel producer.

Due to this convergence of interests, an economic project of the palm oil agro-industry - the development of the palm oil sector - became a national political project of the government. 
The 'selective access to the state' enabled palm growers and palm oil producers to influence policy-making and implementation in their favour, especially during Uribe Vélez's two consecutive governments between 2002 and 2010. During that period, the palm oil agroindustry obtained substantial governmental support in the form of agricultural credit and subsidies, fiscal incentives, and a policy-driven national biodiesel market that would largely absorb palm oil production.

These instruments translated into structural mechanisms of access - access to capital, access to knowledge and technology, and access to markets - that enabled oil palm growers and palm oil producers to expand the palm oil frontier, so gaining access to large extensions of land. These instruments were also applicable to other agricultural and industrial sectors. However, their implementation resulted in an accelerated large expansion of the area cultivated with oil palm, which can be attributed to the great amount of resources that were allocated to the palm oil agro-industry, especially to wealthy individuals and organizations with personal links to the government.

Governmental support was thus a key element of the political economy of land access struggles resulting from the contemporary expansion of the palm oil frontier in Colombia. However, this support is neither exclusive to the palm oil agro-industry nor specific to the Uribe Vélez's government. It is embedded in a historical tendency of governments to pursue models of economic and rural development that privilege capitalist agriculture and an oligarchy of wealthy families, so neglecting the varied and complex modes of rural livelihoods and reinforcing patterns of land concentration and inequitable access to land and hence to the means to a livelihood.

It is possible to draw some conclusions about the relations between governmental support to extractive industries and access to resources from the analysis presented in this chapter about the case of Colombia:

Firstly, the influence of policies on who gains access to resources, and how, is not only defined by the adoption and implementation of tenure regimes that confer property or user rights, but also by policies, laws and governmental measures aimed at promoting economic activities based on the extraction of resources.

Governmental support in the form of incentives and policies to promote extractive activities may translate into relational and structural mechanisms of access that operate in parallel to rights-based and illegal means. Such relational and structural mechanisms constitute the strands of the 'bundle of powers' that enable access to the resources on which the expansion of extraction frontiers is based. 
Actors interested in capital accumulation from extractive activities often rely on 'access to authority' in the form of 'selective access to the state' to benefit from governmental support. They use this relational mechanism to influence the adoption and implementation of policies and measures that work as structural mechanisms of access such as capital, knowledge, technology and access to markets. These structural mechanisms enable them to gain and control access to resources for the expansion of extraction frontiers. Thus, governmental support to extractive activities and the forms of gaining and controlling access to resources this support represents are part of the "political economies of power and accumulation" underlying socio-environmental conflicts (Peluso, 2009: 40).

Secondly, the relational and structural mechanisms at work through governmental incentives supporting extractive activities operate, not only in parallel to rights-based mechanisms, but also in spite of them. Structural mechanisms of access may operate through governmental support to extractive activities that allow benefiting from resources even without controlling access through tenure rights. This is demonstrated in the case of palm oil producers that benefit from land by controlling oil palm plantations of 'productive alliances' that were beneficiaries of governmental support in Colombia.

Moreover, this type of governmental support entails opportunities for capital accumulation and resource control so attractive that interested actors may use both legal and illegal manoeuvres to get around resource tenure regimes in order to participate in the governmentsponsored extractive activities.

Thirdly, the governmental support that privileges specific modes of production and extraction is a manifestation of 'state simplifications' often inscribed in a historical pursuit of economic and rural development guided by a 'high modernist ideology'. ${ }^{23}$ State simplifications typically fail to "represent the actual activity of the society they depict". Moreover "they enable much of the reality they depict to be remade". By doing so, "they make possible quite discrimination interventions" (Scott, 1998: 3).

Thus, models of economic and rural development that privilege extractive activities, such as capitalist agriculture, neglect the plurality of relations that local people establish with the territories they inhabit and the resulting complex and varied livelihoods, and favour access to resources of those aligned with the guiding "high modernist ideology".

\footnotetext{
${ }^{23}$ Scott defines 'high modernist ideology' as "a strong version of the self-confidence about scientific and technical progress, the expansion of production, the growing satisfaction of human needs, the mastery of nature (including human nature), and, above all, the rational design of social order commensurate with the scientific understanding of natural laws" (Scott, 1998: 4).
} 


\section{Chapter 5}

\section{Expansion of Commodity Frontiers, Dimensions of Justice and Human Rights: Justice and Resistance in the Context of the Expansion of the Palm Oil Frontier in Colombia}

\subsection{Introduction}

In this chapter I address Research Sub-question 3 of this dissertation: How are dimensions of justice threatened in practice and defended through human rights politics in local cases of resistance connected with the expansion of commodity frontiers?

As demonstrated in Chapter 3, the expansion of commodity frontiers entails different resource control practices that take the form of 'accumulation by dispossession' (Harvey, 2003), and 'assimilation' (Escobar, 2006a and 2006b). Both types of practices affect local people's livelihoods, so resulting in human rights grievances.

Livelihoods are multi-dimensional. They "are not only economically driven and structured, they are also imbued with cultural and political significance" (Bebbington, 2004: 177). This means that livelihoods are not only sources of subsistence and income, but also sources of identity, meaning, and capabilities understood as freedoms to pursue the lives people value to lead (Bebbington, 1999 and 2004; Bebbington et al., 2008a). 'Accumulation by dispossession' affects livelihoods across their multiple dimensions. 'Assimilation' breaks the complex articulation between such dimensions by denying and erasing the cultural differences that underlie different human groups' relationship with their environments and the natural resources that they depend upon for their livelihoods.

Expansion of commodity frontiers through 'accumulation by dispossession' and 'assimilation' produces, not only injustices in terms of inequitable distribution of material gains and losses, but also it produces grievances affecting:

i) recognition of identity and culture (Fraser, 1998),

ii) capabilities (Sen, 1999 and 2009), and

iii) participation in the decisions that may affect the lives people value to pursue. ${ }^{1}$

\footnotetext{
1 Sen defines 'capability' as "the substantive freedom to achieve alternative functioning combinations". 'Functionings' are defined as "the various things a person may value doing or being" (Sen, 1999: 75). Thus, a set of capabilities represents "the freedoms people enjoy to choose between different ways of living that they can have reason to value" (Sen, 1990: 114).
} 
Thus, these grievances affect the different dimension of environmental justice identified by Schlosberg (2007): distribution; recognition; capabilities; and, participation. ${ }^{2}$ These dimensions of justice form the basis of substantive and procedural human rights.

As a consequence, expansion of commodity frontiers often elicits resistance in defence of livelihoods that results in socio-environmental conflicts. Resistance is operated through varied strategies ranging from the use of 'weapons of the weak' (Scott, 1985) to massive social mobilisation. ${ }^{3}$ Human rights politics is often used in parallel to other strategies (Martinez-Alier, 2002; Schlosberg, 2007). ${ }^{4}$ This reliance on human rights politics as a strategy of resistance can be explained by the emancipatory potential of the human rights framework since it encompasses the different dimensions of justice that underlie the claims of resisting actors.

Schlosberg's pluralistic and multi-dimensional conception of justice underlies much of the recent scholarship on socio-environmental conflicts and environmental justice connected with expansion of commodity frontiers (Carruthers, 2008; Martin, 2013a; Martinez-Alier, 2013; Urkidi and Walter, 2011; Walker and Bulkeley, 2006).

However, only a few studies in the literature on socio-environmental conflicts undertake a justice analysis focused on unveiling the dimensions of justice underlying the conflicts (Urkidi and Walter, 2011; Temper and Martinez-Alier, 2013). These studies analyse how environmental justice dimensions are articulated in the discourses of the actors resisting or opposing the expansion of commodity frontiers. Since these studies remain in the terrain of discourses, they are lacking in a more in-depth analysis of how different dimensions of justice are threatened in practice.

Moreover, most of the research on socio-environmental conflicts and social mobilisation connected with expansion of commodity frontiers focuses on resistance against forms of 'accumulation by dispossession', and the conditions under which such resistance emerges or not (Muradian et al., 2012; Conde and Kallis, 2012). There has been less attention in this literature to analysing resistance within process of 'assimilation' and the emancipatory potential of human rights politics.

\footnotetext{
${ }^{2}$ In Schlosberg's conceptualisation of environmental justice the capabilities dimension is based on Sen's concept of capabilities (see Section 2.2 in Chapter 2).

${ }^{3}$ See Section 2.2.2 in Chapter 2 for details on the Scott's concept 'weapons of the weak'.

${ }^{4} \mathrm{I}$ use the term human rights politics to refer to political action that includes: framing claims in human rights terms, rendering them visible to human rights organizations, trying to influence institutional change through networking, advocacy and lobbying, and bringing cases before the human rights jurisdiction at national and supranational levels (Asian, African, Inter-American and European human rights systems that include commissions and courts).
} 
In this chapter I aim to fill the gaps in the literature mentioned above. To do so, I analyse how dimensions of justice are threatened in practice and defended in local cases of 'accumulation by dispossession' and 'assimilation' connected with the expansion of commodity frontiers. The analysis is based upon two cases of resistance against 'accumulation by dispossession', and one case of resistance against 'assimilation', all connected with the 2000-2010 expansion of the palm oil frontier in Colombia.

As detailed in Chapter 3, the trajectories of expansion of the palm oil frontier in Colombia between 2000 and 2010 encompassed practices of land control at the local level that took the form both of 'accumulation by dispossession' and of 'assimilation'. Thus, the empirical study of cases of conflict and resistance against such practices contribute to shed light on:

i) how expansion of commodity frontiers threatens different dimensions of justice in practice at the local level, and

ii) the potential of human rights politics as an instrument of resistance against the injustices elicited by such expansion.

This chapter is structured as follows: in Section 5.2, I present the conceptual and analytical framework on which the analysis is based. In Section 5.3, I explain case selection criteria and data collection methods. In Section 5.4, I present the results of the empirical analysis. Section 5.4 is divided into three parts: in Section 5.4.1, I present the national and local context of expansion of the palm oil frontier in which the three cases are placed. I describe the context in light of its implications for local populations' access to land. In Section 5.4.2, I analyse the three cases in light of the different livelihood dimensions of the peasants involved in resistance, and the strategies they used to defend them. In Section 5.4.3, I analyse how the threats to different livelihood dimensions identified in Section 5.4.2 affect the different dimensions of justice in practice, and the emancipatory potential of human rights politics. Section 5.5 presents the conclusions.

\subsection{Analytical and conceptual framework: expansion of commodity frontiers, resistance, livelihoods and justice}

The expansion of commodity frontiers often affects local people's access to the natural resources that constitute the material and cultural bases of their livelihoods (Martinez-Alier, 2002; Bebbington et al., 2008a). Access is hindered through, either physical dispossession (i.e. eviction, displacement, locking out, relocation), or the transformation of the environments that sustain people's livelihoods. Thus, resource access struggles connected 
with the expansion of commodity frontiers are about the defence of livelihoods against the threats that such expansion entails (Martinez-Alier, 2002; Muradian et al., 2012).

The empirical analysis carried out in this chapter is built upon the interrelations between access to resources, a multi-dimensional notion of livelihoods (Bebbington, 1999 and 2004; Bebbington et al., 2008a), Schlosberg's pluralistic and multi-dimensional conceptualization of environmental justice (Schlosberg, 2004 and 2007), and human rights. Fig. 5.1 shows the interrelations between access to resources; the dimensions of livelihoods; the dimensions of justice; and, human rights.

Resource control practices of 'accumulation by dispossession' and 'assimilation' used for the expansion of commodity frontiers may affect different dimensions of people's livelihoods at the local level. Harvey used the rubric of 'accumulation by dispossession' to refer to the continuation of all practices labelled by Marx as 'primitive accumulation'. He considered that these practices appear, either in the same forms identified by Marx, or in new guises (Harvey, 2003 and 2007). 'Accumulation by dispossession' encompasses any process of livelihoods deprivation. Thus, it may affect any of the different livelihood dimensions.

Escobar uses the term 'assimilation' to refer practices of incorporation of local populations into modern processes of development, in an attempt to realise a measure of equity, that deny differences rooted in identity and culture (Escobar, 2006a and 2006b). 'Assimilation' practices may appear as livelihoods opportunities. Instead, these practices entail the colonization of people's 'lifeworlds' - "their domains of everyday meaningful practice" (Habermas, 1987 quoted in Bebbington et al., 2008a), so breaking up the complex articulation between the three dimensions of livelihoods.

\footnotetext{
${ }^{5}$ In Harvey's words 'accumulation by dispossession' practices include: “(1) the commodification and privatization of land and the forceful expulsion of peasant populations; (2) conversion of various forms of property rights (common, collective, state, etc.) into exclusively private property rights; (3) suppression of rights to the commons; (4) commodification of labor power and the suppression of alternative (indigenous) forms of production and consumption; (5) colonial, neocolonial, and imperial processes of appropriation of assets (including natural resources); (6) monetization of exchange and taxation, particularly of land; (7) the slave trade (which continues, particularly in the sex industry); and (8) usury, the national debt, and, most devastating of all, the use of the credit system as radical means of primitive accumulation" (Harvey, 2003 and 2007). This is only an indicative list as Harvey observes that since Marx's analysis "wholly new mechanisms of accumulation by dispossession have also opened up" (Harvey, 2003: 147-148).
} 
Fig. 5.1. Analytical framework: interrelations between access, livelihoods, justice and human rights ${ }^{6}$

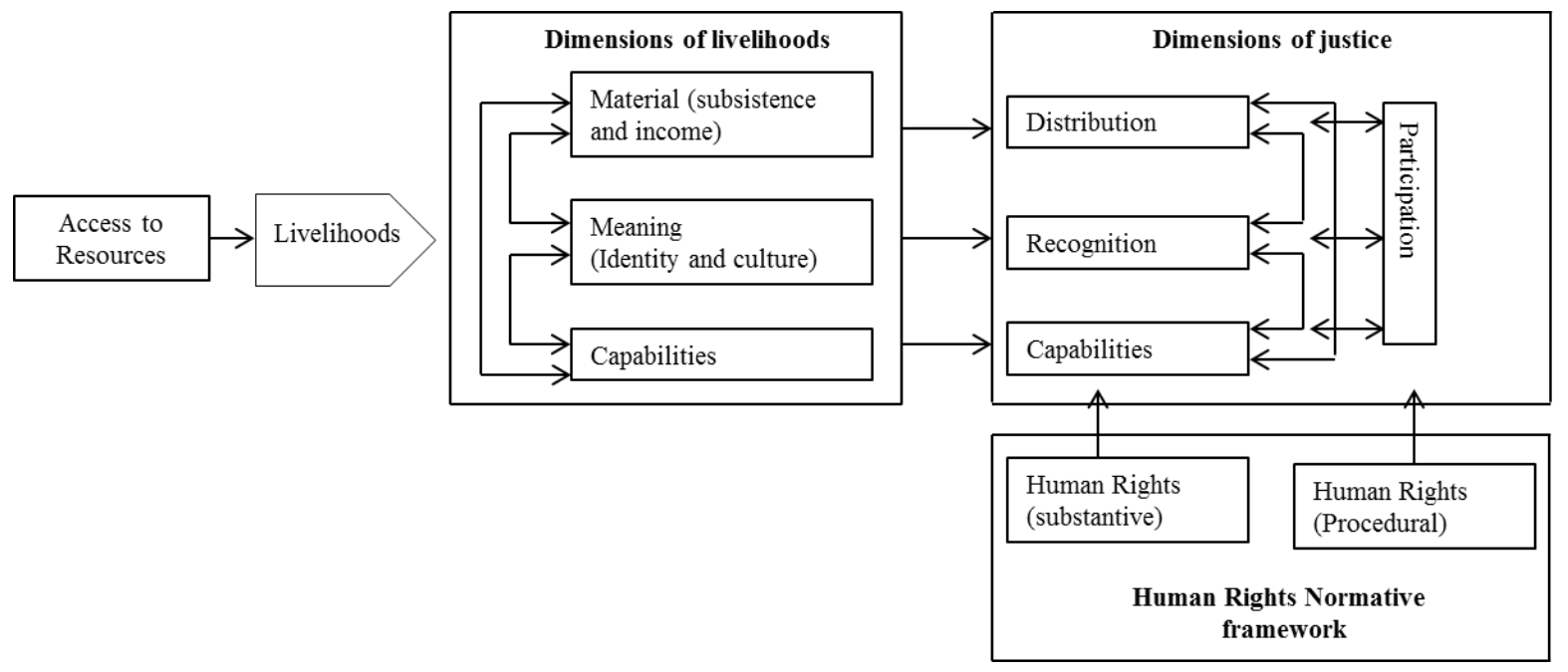

Source: own construction

${ }^{6}$ The capabilities dimension in both Schlosberg's conceptualisation of environmental justice and Bebbington's notion of livelihoods is based on Sen's concept of capabilities (see Section 2.2 in Chapter 2). 
Therefore, local people's resistance in defence of their livelihoods may emerge when expansion of commodity frontiers takes place through processes both of 'accumulation by dispossession' and of 'assimilation'. Thus, resistance arises as "a vehicle for contesting both the colonization of 'lifeworlds' and the material threats to livelihood that flow from accumulation by dispossession" (Bebbington et al., 2008a: 2891). This resistance is reflected in the languages of contestation used by local people involved in resource access struggles and socio-environmental conflicts connected with the expansion of commodity frontiers. Such languages often articulate a plurality of values that denote the multiple dimensions of livelihoods. They allude to the importance of access to resources for subsistence and income generation practices. At the same time, they emphasise that such practices shape and are shaped by individual and/or collective values, such as identity, culture, sacredness, and kinship, which are:

i) incommensurable in economic or monetary terms, and

ii) inextricably connected with local resources and environments

(Martinez-Alier, 2002; Martinez-Alier et al., 2010; Muradian et al., 2012).

The various dimensions of local people's livelihoods compromised by the expansion of commodity frontiers convey the multiple dimensions of justice (Schlosberg, 2007; Martinez-Alier, 2013). Thus, local people's struggles for access to resources threatened by extractive activities can be seen in terms of demands for justice. It is possible to identify four dimensions of justice:

i) equitable distribution of resources (distributional justice);

ii) recognition of the difference in 'lifeworlds' that underlies their interaction with local resources and environments (justice as recognition);

iii) participation in the decisions affecting people's lives and concerning the resources and environments their livelihoods depend upon (procedural justice), and

iv) the capabilities to lead the lives people value to pursue.

These four dimensions of justice - distribution, recognition, participation and capabilities were brought together by Schlosberg in a pluralistic approach to environmental justice that corresponds with both the multiple dimension of livelihoods, and the incommensurability of values underlying local people's contestation and resistance (Schlosberg, 2007: 169).

These four dimensions can be articulated, not only at the individual level, but also at the community level (Schlosberg, 2007; Schlosberg and Carruthers, 2010). These dimensions form the basis of both substantive human rights (social, economic, cultural and territorial 
rights) and procedural human rights (consultation and free, prior and informed participation).

As Adeola points out, “because human rights involve the assurance of people's means of livelihood, any threats to environmental bases of livelihood could be considered a violation of basic human rights" (Adeola, 2000: 689). The human rights framework - in particular social, economic, cultural and territorial rights - encompasses the distribution, recognition and capabilities dimensions of justice compromised by the threats that the expansion of commodity frontiers poses to local people's livelihoods.

Furthermore, procedural human rights account for the participation dimension, in particular, the rights to consultation and to free, prior and informed participation and consent. These procedural rights are aimed at ensuring consultation with, and decision-making power of, local communities in relation with the activities that have the potential to transform the territories they depend on. ${ }^{7}$

Thus, human rights (collective, individual, substantive and procedural) can be used as instruments of resistance when local people's livelihoods are threatened by the expansion of commodity frontiers. However, the emancipatory potential of the human rights framework depends on whether and how local meanings are taken into account in the interpretation and application of such framework (Santos, 2002 and 2007).

"Human rights are not universal in their application" (Santos, 2002: 44) as there are national and regional regimes - European, Inter-American, African and Asian. Moreover, the ways in which such regimes are defined and applied are shaped by cultural meaning and context-based political action (Santos, 2002 and 2007). Strategies of resistance based on human rights politics used by local actors whose livelihoods are threatened by the expansion of commodity frontiers are an example of context-based political action. Such human rights-based political action is imbued with cultural and local meanings. Thus, it contributes to the construction of a multicultural conception of human rights that takes into consideration what human rights mean for unrecognised and marginalised human groups.

Boaventura de Sousa Santos defines the multicultural conception of human rights as "a conception that instead of resorting to false universalisms, organizes itself as a constellation of local and mutually intelligible local meanings, networks of empowering normative references" (Santos, 2002: 47). When human rights are conceived in this manner, they

\footnotetext{
${ }^{7}$ See more details about the concept of territory in Chapters 2 and 7.
} 
constitute an instrument of emancipatory politics for unrecognized, marginalised or silenced individuals, groups and associations (Santos, 2002 and 2007).

Under the multicultural conception, the human rights framework is a normative reference. Its potential to serve emancipatory politics depends on how that normative reference is articulated with local meanings. The analysis of the emancipatory potential of human rights-based strategies of resistance carried out in this chapter is based on this multicultural conception of human rights.

\subsection{Materials and methods}

I focus on three of the local cases reported in Chapter 3 to analyse how dimensions of justice are threatened in practice and defended through human rights politics in local cases of resistance connected with the expansion of commodity frontiers. I selected cases of land access struggles that are representative of land control practices of both 'accumulation by dispossession' and 'assimilation' in the Central Region of the palm oil geography, yet which shared resistance against palm oil growers/producers, geographical location and similar time lines (2000-2010 period), as shown in Table 5.1. ${ }^{8}$

In order to analyse the potential of 'multicultural human rights' politics for the defence of different dimensions of justice, the cases selected include one in which human rights litigation was one of the strategies of resistance (Case 1 in Table 5.1).

The analysis relies in both primary and secondary data. Primary data was collected during fieldwork between August and December of 2011.

Data on Case 1 come mainly from secondary sources. The details of the case and the views of the local actors have been broadly reported through different sources that were crosschecked.

Data on Cases 2 and 3 come mainly from primary sources, in particular interviews and group meetings during fieldwork.

This primary data was complemented with documents and reports about the cases also collected during fieldwork. Direct accounts of the cases narrated by members of the three peasants associations involved in the cases were also crosschecked with recollections of key informants with in-depth knowledge of the cases (see the list of interviewees and group meetings in Appendix A - Table A.2). Most of the interviewees are not identified by their names because of safety reasons or because they asked to remain anonymous.

\footnotetext{
${ }^{8}$ See Section 2.2.1 in Chapter 2 for more details about the reasons for selecting cases in the Central Region of the palm oil geography for this thesis.
} 
Table 5.1. Details of the cases of 'accumulation by dispossession' and 'assimilation' selected for the analysis in Chapter 5

\begin{tabular}{|c|c|c|c|c|c|c|c|}
\hline & \multirow{2}{*}{$\begin{array}{l}\text { Resisting Local } \\
\text { Actors }\end{array}$} & \multirow{2}{*}{$\begin{array}{l}\text { Oil Palm } \\
\text { Growers/ } \\
\text { Palm Oil } \\
\text { Producers }\end{array}$} & \multicolumn{3}{|c|}{ Geographical Location } & \multirow{2}{*}{$\begin{array}{l}\text { Land Access } \\
\text { Control } \\
\text { Practices }\end{array}$} & \multirow{2}{*}{$\begin{array}{l}\text { Time } \\
\text { Line }\end{array}$} \\
\hline & & & $\begin{array}{c}\text { Region In } \\
\text { The Palm } \\
\text { Oil } \\
\text { Geography }\end{array}$ & $\begin{array}{c}\text { Region In } \\
\text { National } \\
\text { Geography }\end{array}$ & Municipality & & \\
\hline \multirow{3}{*}{$\begin{array}{l}\tilde{w} \\
\tilde{c} \\
\tilde{U}\end{array}$} & 1. ASOCAB & $\begin{array}{l}\text { El } \\
\text { Labrador } \\
\text { Consortium }\end{array}$ & Central & $\begin{array}{l}\text { South of } \\
\text { Bolivar } \\
\text { province } \\
\text { (border } \\
\text { with } \\
\text { Magdalena } \\
\text { Medio) }\end{array}$ & El Peñón & $\begin{array}{l}\text { 'Accumulation } \\
\text { by } \\
\text { dispossession' }\end{array}$ & $\begin{array}{c}2007- \\
\text { present }\end{array}$ \\
\hline & $\begin{array}{l}\text { 2.ASOPRODAGRO } \\
\text { PC }\end{array}$ & Indupalma & Central & $\begin{array}{l}\text { Magdalena } \\
\text { Medio }\end{array}$ & San Alberto & $\begin{array}{l}\text { 'Accumulation } \\
\text { by } \\
\text { dispossession' }\end{array}$ & $\begin{array}{l}2002- \\
\text { present }\end{array}$ \\
\hline & 3. ASOBENPRO & Indupalma & Central & $\begin{array}{l}\text { Magdalena } \\
\text { Medio }\end{array}$ & $\begin{array}{l}\text { Sabana de } \\
\text { Torres }\end{array}$ & 'Assimilation' & $\begin{array}{l}2007- \\
2009\end{array}$ \\
\hline
\end{tabular}

The analytical strategy was threefold:

Firstly, I placed the three cases in the national and local context of the contemporary expansion of the palm oil frontier and its implications in terms of rural people's access to land.

Secondly, by looking into the valuation languages conveyed by the members of the peasants associations in the different data sources used for this chapter, I identified the livelihood dimensions articulated in ASOCAB's, ASOPRODAGRO PC's and ASOBENPRO's members' claims. ${ }^{9}$

Thirdly, I connected these livelihood's dimensions with the different dimensions of social justice. On the basis of Case 1, I paid special attention to the emancipatory potential of human rights litigation for the defence of the different dimensions of justice.

\footnotetext{
${ }^{9}$ I draw here upon Hall's notion of articulation which has a dual meaning: "It is the process of rendering a collective identity, position, or set of interests explicit (articulate, comprehensible, distinct, accessible to an audience), and of conjoining (articulating) that position to definite political subjects" (Hall, 1996 cited in Li, 2004: 311).
} 


\subsection{Expansion of the palm oil frontier and dimensions of justice in three cases of resistance in Colombia}

5.4.1. The context: the expansion of the palm oil frontier in the Central Region of the palm oil geography

As explained in Chapter 3, the material requirements of the crop - edapho-climatic conditions and the maximum time interval between harvest and extraction of the oil - define the characteristics of the palm oil geography.

Oil palm cultivation expands forming enclaves around palm oil extraction plants in the geographical regions that offer the appropriate edapho-climatic conditions for the palms to grow.

Dramatic socio-ecological changes underlie the specific landscapes that result from palm oil expansion in the form of enclaves. Oil palm cultivation for industrial palm oil production uses monoculture planting abiding by particular technical specifications that ensure the productivity of the process, and hence its profitability. For example, a plantation has about 143 palms per hectare. Excess of water needs to be drained. On the other hand, if there is water scarcity, palms need to be irrigated. The infrastructure for both irrigation and drainage consists of about 450 metres of canals per hectare (Fedepalma, 2011b).

Thus, the establishment of an oil palm plantation entails a drastic transformation of landscapes from mixed indigenous vegetation or peasant farms to monoculture. Pictures 5.1 and 5.2 show the contrast between the oil palm plantations landscape and the landscape of typical peasant farms.

The transformation of the landscape has consequences for local people's livelihoods. The techniques of industrial oil palm plantation are not compatible with the agricultural practices of peasants. In contrast with the mosaic of agricultural products and activities found in a traditional peasant farm (Picture 5.2), an oil palm plantation is a monoculture that cannot coexist with people, animals or other crops that are not functional to the development of the plantation. Therefore, local people that refuse to devote their lands to oil palm cultivation in the area bordering on a plantation have to be excluded from the physical space. The same applies for animals and crops that may affect the development of the palms. 
Picture 5.1. Photographs of landscapes of agro-industrial oil palm plantations

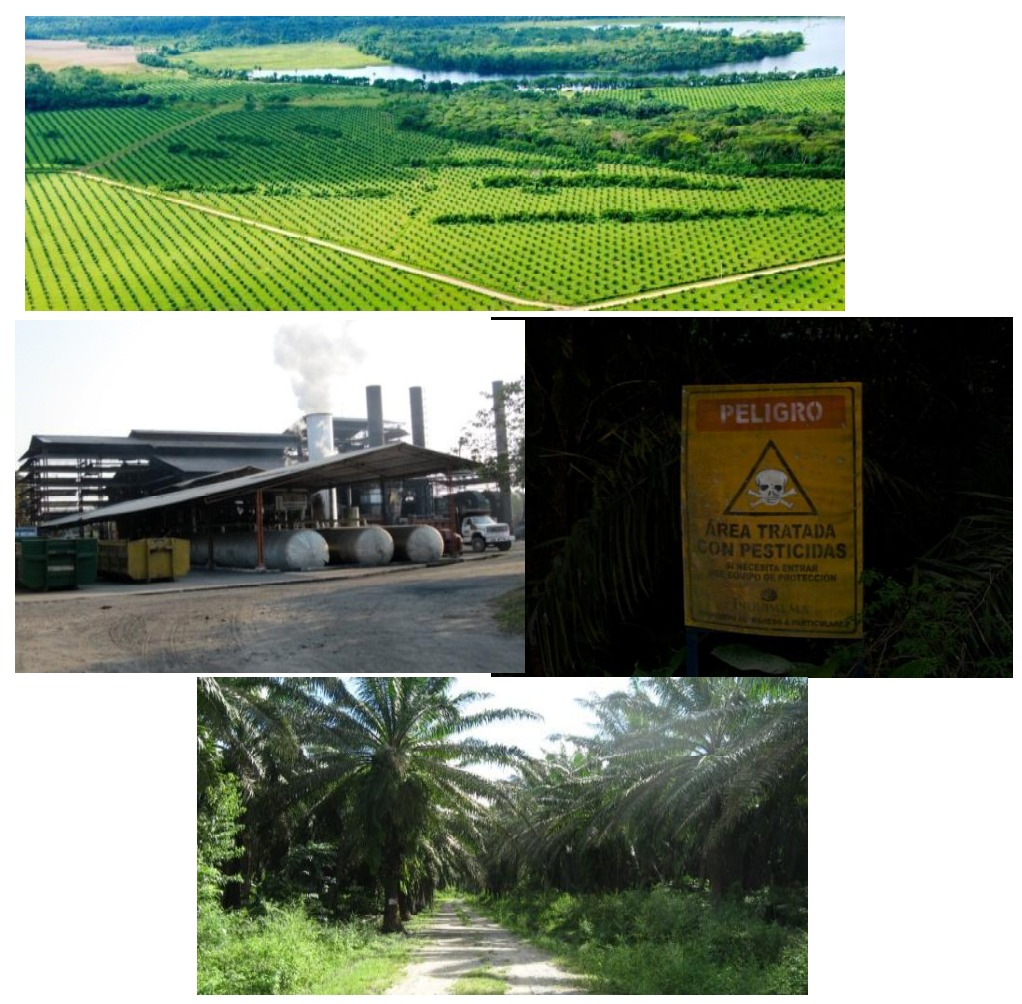

Picture 5.2. Photographs of landscapes of typical peasants farms

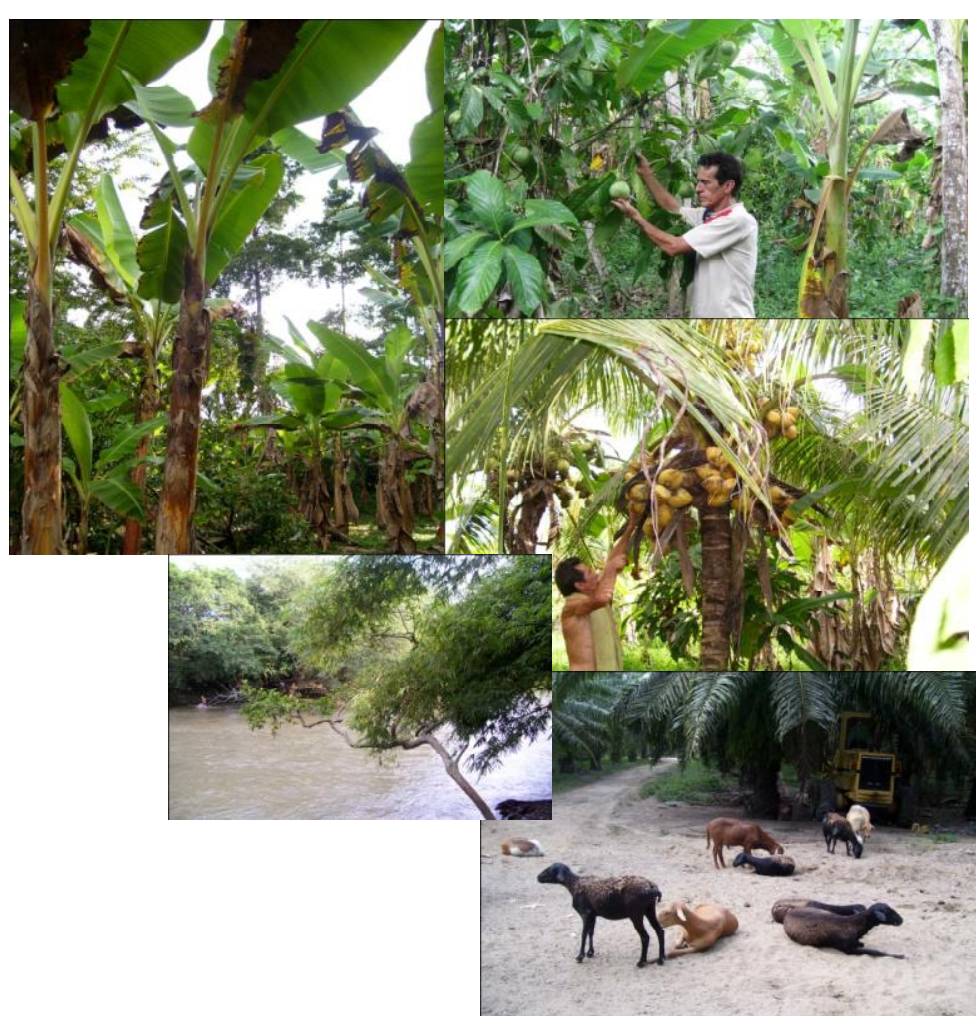

Source: all the pictures were taken by the author during fieldwork, except the first in the left upper corner that was taken by José Sánchez Hachero, who authorized its use. 
Thus, oil palm monoculture expansion is highly exclusionary. It requires "emptying the territories" of living communities. Moreover, as palm nuclei expand taking the form of enclaves, territorial transformation advances from the agro-industrial estate across the geographical region, so producing remarkable physical changes (and visual impacts) that affect the natural material basis of local people's livelihoods. Forero-Álvarez refers to the type of agricultural enclaves produced by oil palm monoculture as "spaces of the agrarian capitalism" in which the capitalist agro-industry has homogenized the socio-productive landscape (Forero-Álvarez, 2010b). ${ }^{10}$

These socio-ecological transformations of oil palm expansion are remarkable in the region of the palm oil geography where the three cases selected for the analysis come from; that is the Central Region, which includes municipalities located within, or in the border with, the sub- regions of Catatumbo and Magdalena Medio of the national geography (see Map 5.1). The cases come specifically from the Magdalena Medio sub-region (Municipalities of San Alberto and Sabana de Torres) and a neighbouring locality (Municipality of El Peñón).

Although the first plantations in the Central Region started in the 1960s, cultivation of oil palm increased rapidly between 2000 and 2010, from about 54,000 hectares in 2000 to about 113,000 in 2010 (Fedepalma, 2005 and 2011a). In 2000, there were eight palm oil extraction plants in operation in the Central Region. By 2010, there were ten in operation and three more in construction, owned by thirteen different organizations. Moreover, seven out of the ten palm oil extraction companies in operation established a biodiesel refinery Ecodiesel - in association with the national oil company Ecopetrol.

The expansion of oil palm cultivation in the Central Region has been to a large extent driven by the demand of the palm oil extraction companies established in the same region for oil palm fresh fruit bunches (FFB). This is the situation in the expansion in the municipalities of San Alberto and Sabana de Torres (Cases 2 and 3). However, in the northern part of the Magdalena Medio sub- region the new frontiers are being opened up by palm oil producers from the North Region of the palm oil geography. This is the situation in the municipality of El Peñón (Case 1).

\footnotetext{
${ }^{10}$ According to Forero-Álvarez (2010b), it is possible to identify six types of spaces in the Colombia rural landscape: i) spaces of agrarian capitalism, ii) spaces of rural capitalism (where family farming coexists in an functional relationship with the capitalist farms, iii) spaces where small, medium and large producers of mechanized crops (corn, rice and cotton) coexist, iv) peasant spaces, v) spaces disputed between peasants and large land holders who devote the land mainly to cattle raising (latifundios), and vi) spaces of colonization where peasants, colonizing industries (extractive or cattle raising), new latifundios and indigenous communities converge.
} 
Map 5.1. Geographical localization of the cases analysed in Chapter $5^{11}$

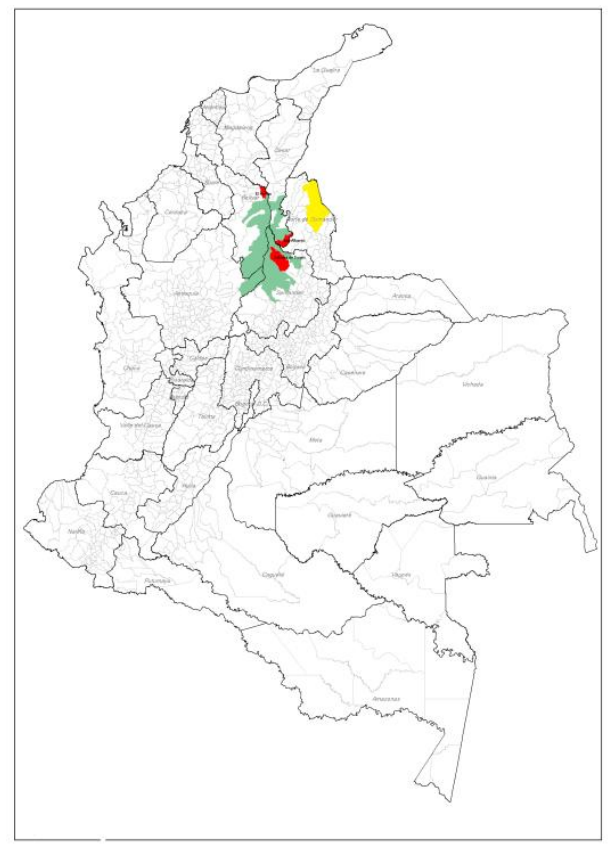

Municipatilites of the Magdalena Medio sub-region (in green and red) and Catatumbo sub-region (in yellow) with oil palm plantations in 2010.

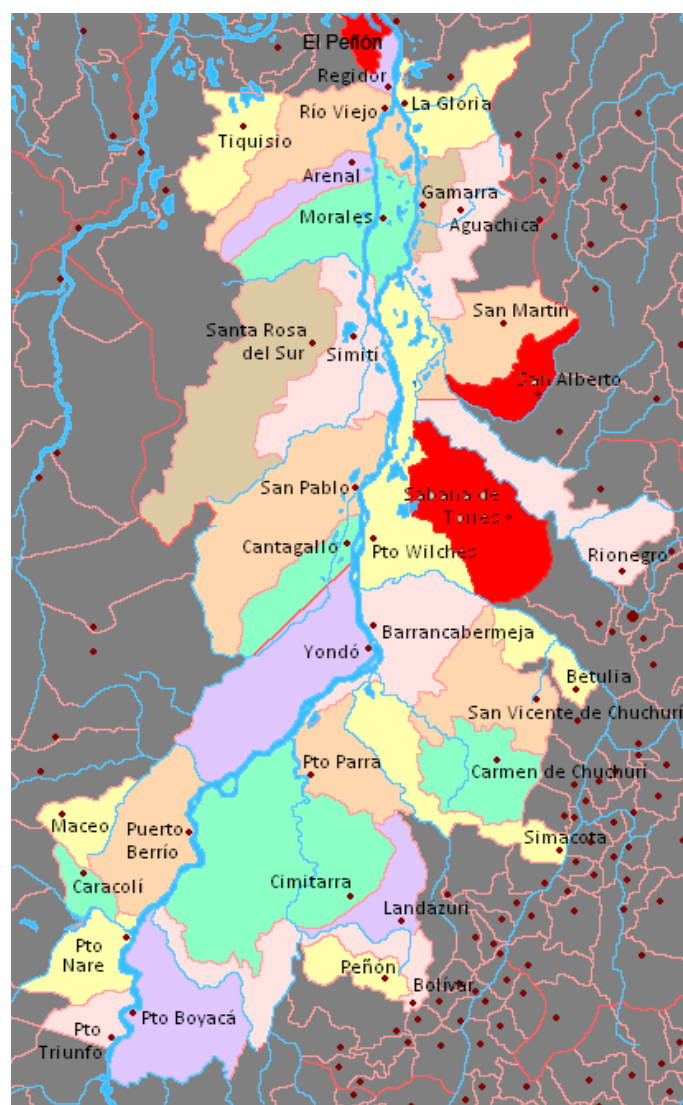

Municipalities of the Magdalena Medio subregion + El Peñón. The cases are located in the municipalities in red (San Alberto, Sabana de Torres and El Peñón).

\footnotetext{
${ }^{11}$ The map with the municipalities the Magdalena Medio sub-region was elaborated by Shadowxfox. Creative commons attribution: by Shadowxfox (Mapa del Magdalena Medio por municipios) [GFDL (http://www.gnu.org/copyleft/fdl.html) or CC-BY-3.0 (http://creativecommons.org/licenses/by/3.0)], via Wikimedia Commons.
} 
From the land cover changes reported by Castiblanco et al. (2013), it can be inferred that the 2000-2010 expansion of oil palm cultivation in the Central Region produced substantial socio-ecological transformations. Castiblanco et al. (2013) found that the $17.3 \%$ of the land on which the expansion of oil palm cultivation took place in the Central Region between 2002 and 2010, was previously covered with natural vegetation (primary and secondary forest, and savannas), $20 \%$ corresponded to heterogeneous agricultural areas (including mosaic of crops; mosaics of crops and natural areas; and mosaics of crops, pastures and natural areas), $6.2 \%$ was previously covered with cocoa, coffee and sugar cane, and $50.7 \%$ was previously covered with pastures. Pastures are typically found in large estates devoted to cattle ranching. Heterogeneous agricultural areas represent the typical land coverage of peasant's farms (Forero-Álvarez, 2002). Cocoa and coffee are also typically cultivated in small-scale farms (Forero-Álvarez, 2002).

The palm oil agro-industry has argued that since most of the land coverage transformation caused by the recent expansion of oil palm cultivation has occurred on pasture or crop land rather than on forest land, hence, this expansion can be considered sustainable (Mesa Dishington, 2013; Rodríguez-Becerra and Van Hoof, 2005). However, the social sustainability of this expansion is questionable. It cannot be ignored that over $25 \%$ of the transformation in the Central Region involved peasants' and small-scale farmers' land. Therefore, the expansion of oil palm cultivation might have affected the livelihoods of the peasants and farmers whose lands were transformed into oil palm plantations. Moreover, transformation of pasture land into oil palm plantations may have also affected the livelihoods of local landless people or people with very small parcels of land. During fieldwork interviews it was mentioned that some of these local people resort to two different types of arrangements with the owners of cattle ranching estates:

i) sharecropping agreements to use small areas of the estate for small-scale farming, and

ii) agreements in which the land owner allows local people to bring their cattle to graze on the estate and receive the same care as the cattle of the owner of the estate in exchange for part of the profit obtained when the cattle are sold. This type of agreement is called 'ganado al aumento' (fieldwork interviews, Forero-Álvarez, 2002).

These arrangements guarantee, totally or partially, a livelihood for local people who are landless or possess very small parcels. Because of the exclusionary character of oil plantations explained above, the practices of sharecropping or 'ganado al aumento' are not possible in the lands devoted to oil palm cultivation. 


\subsubsection{The cases}

\subsubsection{Case 1 - Conflict between ASOCAB (Asociación de Campesinos de Buenos Aires)} and El Labrador Consortium:

The land access struggle of ASOCAB's peasant families against El Labrador Consortium for the lands located on the estate called Las Pavas came into public domain in 2009 when the eviction of the peasant families was reported by both the national and international media (El Tiempo, 2009; Molano Bravo, 2009b; The Observer, 2009).

The dispute started in 2007 and revolved around about 2,600 hectares of land of Las Pavas estate located within the municipality of El Peñon in the area called Corregimiento de Buenos Aires. The municipality of El Peñón limits are with the municipality of Regidor that is part of the Magdalena Medio sub-region (see Map 5.1). These two municipalities, together with the municipality of Rio Viejo (Magdalena Medio sub-region) form Papayal Island, which is one of the new frontiers of palm oil expansion. Papayal Island is however home to a complex ecosystem of marshlands and water streams connected to the Magdalena River. Some of these marshlands and water streams which pass through Las Pavas estate are being drained and polluted by oil palm cultivation activities (Vargas et al., 2010).

In order to establish oil palm plantations, the Consortium bought Las Pavas in March 2007 from a person that claimed to have been the legal owner since 1983 (hereafter I will refer to this person as the 'apparent owner'). ${ }^{12}$ The Consortium was formed from two companies: Aportes San Isidro and C.I Tequendama. Aportes San Isidro is involved in the expansion of the palm oil frontier on Papayal Island, not only on Las Pavas, but also in the municipality of Regidor (Enlaza, 2009; Vargas et al., 2010). C.I Tequendama is an affiliate company of the DAABON business group.

DAABON is a well-established palm oil producer in Colombia and partially owns a biodiesel refinery in the North Region of the palm oil geography. DAABON has historically

\footnotetext{
${ }^{12}$ I use the expression "who claimed to be" because the Colombian Institute for Rural Development (INCODER) - the governmental agency in charge of clarifying the ownership of land in rural areas adopted two decisions in relation to Las Pavas in 2012. In the first decision, the INCODER asserted that part of the land in dispute was public land owned by the state. In the second decision, the INCODER declared extinct the ownership rights of 'apparent owner', because the 'apparent owner' had not exploited the land for more than three continuous years (Law 160, 1994). After these decisions ASOCAB members could start the legal process to obtain the title of the land by demonstrating that they have been using the land for at least five years, as required by the Colombian Agrarian Law (Law 160, 1994).
} 
developed its palm oil activities in the North Region. ${ }^{13}$ However, it has recently led the expansion of the palm oil frontier on Papayal Island. The expansion has been not only by acquiring land for their own plantations (as in the case of Las Pavas), but also through the contract farming arrangements known as 'productive alliances' (see Chapter 3). DAABON has established 'productive alliances' for the plantation of oil palm in about 1,500 hectares in the municipality of Rio Viejo (SGS, 2010). However, DAABON left the Consortium by selling its shares to Aportes San Isidro in October 2010 as the dispute put at risk its commercial interests. This was for two reasons:

Firstly, DAABON was concerned about the effect of the dispute on its application to obtain certification under the sustainability principles of the RSPO (Roundtable on Sustainable Palm Oil).

Secondly, the visibility of the dispute was affecting DAABON's reputation to the point that one of its most important international costumers - The Body Shop - commissioned an independent report about the case and, on the basis of the findings, terminated the supply contract. $^{14}$

ASOCAB's members are 123 families of peasant farmers from the Corregimiento de Buenos Aires. They grow subsistence crops. In 1998, they formed the association to organise themselves for small-scale commercial production of cocoa. In 1997, ASOCAB's families noticed that Las Pavas was abandoned by the 'apparent owner', so they started to occupy the estate and planted crops. ASOCAB's families stayed on the land until 2003, when they were subject to forced displacement by paramilitary groups. Between 2003 and 2006, some of the families intermittently returned to the estate and re-established crops. In 2006, ASOCAB's families initiated the legal actions necessary to obtain recognition of their tenure rights. ${ }^{15}$ In the same year, ASOCAB's members were again threatened with eviction.

\footnotetext{
${ }^{13}$ DAABON owns plantations in the North Region of the palm oil geography amounting to about 3,000 hectares in 2010, and has established 'productive alliances' in the same region through which it controls about 1,700 hectares (data from 2010) (SGS, 2010). DAABON's palm oil extraction plant is also located in the North Region, as well as the biodiesel refinery - Biocombustibles Sostenibles del Caribe S.A. - the ownership of which is shared with Palmeras de la Costa s.a.

${ }^{14}$ See http://www.thebodyshop.com.au/ValuesAndCampaigns.aspx?Id=235\#.UjhILsV25I0 (Accessed September 17, 2013). Palm oil is one of the raw materials used to produce soaps and other cosmetic products. The Body Shop is a multinational company that produces cosmetics, and hence it is an important buyer of palm oil in the international market. The Body Shop is also a founding member of the RSPO. The Body Shop has a strong ethical policy (at leas that is its stated intention) and much of its reputation is built on this. That is not to say it does not make poor judgements but it should respond to negatives (which is what seems to have happened in the case of Las Pavas).

15 In 2006, ASOCAB's members filed a petition asking the INCODER to start the procedure established in the Colombian Agrarian Law to declare extinct the ownership rights of the 'apparent owner' of Las Pavas.
} 
The threats came from the 'apparent owner', who reappeared to finalise the sale of the land to the El Labrador Consortium (Constitutional Court of Colombia, 2011; Vargas et al., 2010).

Since Las Pavas was sold to Aportes San Isidro and C.I Tequendama in 2007, the Consortium used different means (for example, dismantling shelters, destruction of crops and legal actions) to limit ASOCAB's members' access to the land. The dispute escalated to the point that the Consortium managed to get an order of eviction that was executed by the police in July 2009. The eviction drew the attention of the media resulting in the dispute gaining international recognition, for example national and international newspapers covered the story (El Tiempo, 2009; The Observer, 2009).

In April 2011, ASOCAB's members decided to return peacefully to the land as a form of resistance. The members of ASOCAB were strongly supported by local, national and international Non-Governmental Organizations (NGOs), in particular the Corporation Development and Peace of the Magdalena Medio (CDPMM) which provided legal support and advocacy.

ASOCAB's members adopted different strategies of resistance including:

i) the peaceful return to the land after eviction,

ii) networking with national and international civil society organizations in order to make the case visible through the media and catch the attention of customers of the Consortium's members,

iii) a legal strategy to obtain the recognition of the ASOCAB's families' tenure rights, and,

iv) human rights litigation.

Because of the relevance for this chapter, I want to stress that framing their claims in terms of human rights and resorting to the human rights jurisdiction was one of the ASOCAB's resistance strategies that resulted in one of the most remarkable accomplishments in terms of guaranteeing access to land.

In May 2011, the Constitutional Court of Colombia delivered a judgement embedded in human rights considerations, which stated that ASOCAB's members should be able to stay on Las Pavas until tenure rights were clarified, and ordered the government to carry out the procedures conducive to that clarification (Constitutional Court of Colombia, 2011). In 2012, the Colombian Institute for Rural Development (INCODER) - the governmental agency in charge of clarification of ownership rights over rural land - declared the 
ownership rights of 'apparent owner' extinct with regard to some of the plots on Las Pavas. As a consequence, the ownership went to the state. The INCODER also found that the remaining plots were public lands illegally appropriated by the 'apparent owner'. As a consequence, occupation of those plots by the El Labrador Consortium was illegal (INCODER, 2012a and 2012b). Since the state's ownership over Las Pavas was asserted by the INCODER, ASOCAB's members could start the procedure for the recognition of their tenure rights based on ASOCAB's previous occupation and productive use of the land for more than five years (Law 160, 1994).

At first sight, ASOCAB's struggle against the El Labrador Consortium is a land tenure dispute rooted in a complex history of land occupation in Colombia. A history in which land concentration, appropriation of public lands and irregular transfer of land tenure rights overlap with legitimate, but unrecognised occupation by peasants, forced displacement, eviction and institutional weakness.

However, the resistance of ASOCAB's members is articulated in terms more complex than a property rights dispute. It is grounded in the material, capabilities, and meaning - in particular, identity and the sense of belonging - dimensions of land-based livelihoods, threatened by both the eviction from the lands and the establishment of oil palm plantations.

The different dimensions of ASOCAB's members' livelihoods are inextricable connected with the land. As regards the material dimension, the main productive and subsistence activities of ASOCAB's members are dependent on the land as they are farmers and the crops they used to cultivate in Las Pavas were their source of food and income. This is as expressed by one of the members of ASOCAB in a short documentary recorded at the time they had been evicted:

Original in Spanish:

"Para mi era uno de los mejores años que he podido pasar, ya que ahí cultivábamos el pancoger, como que la yuca, el maíz, y con ese cultivo nos sosteníamos tanto en alimentación como en lo económico... Si nosotros pudiéramos regresar a Las Pavas, pues nuevamente cultivamos lo que siempre hemos cultivado, el maíz, la yuca, el plátano, el ñame, patilla, auyama ....y viviríamos feliz." (Testimony of a member of ASOCAB). Source: Fundación Chasquis Comunicación and Fundación Contravía, 2011.
English own translation:

"For me those were the best years I have experienced, because there (referring to Las Pavas) we used to cultivate crops for food such as cassava, maize... and with those crops we sustained both food and economic needs. If we could return to Las Pavas, we would cultivate again what we have always cultivated.. maize, cassava, plantain, ñame, watermelon, pumpkin... and we would live happily". 
Moreover, ASOCAB's members' also establish a two-way connection between their modes of production and subsistence and their identity and culture. Thus, they articulate the material dimension of land-based livelihoods with the meaning dimension. They refer to themselves as campesinos, which gives identity and cultural meaning to that 'way of being' in terms of their interaction with the land and their traditional farming practices, as the following quote illustrate:

Original in Spanish:

"La tierra es que sin ella no podemos vivir, porque si nosotros los campesinos lo que sabemos es poner a la tierra a producir para lo que consumimos, entonces que somos nosotros sin la tierra? Nada!."

(Testimony of Misael Payares representative of $\mathrm{ASOCAB}$ - during the time ASOCAB's members were out of the land after eviction).

Source: Contreras and Figueroa, 2010.
English own translation:

"The land...we cannot live without it, because what we - the campesinos - know is how to make the land give us what we consume... then, what are we without the land? Nothing!."

In addition, they have an historical attachment to the territory that gives meaning to those lands. They have traditionally inhabited the geographical space of the Corregimiento de Buenos Aires and Papayal Island, establishing emotional bonds with the place and developing a sense of belonging, as the following quotes by one of the ASOCAB's leaders illustrate:

Original in Spanish:

"La verdadera casa nuestra es Las Pavas porque es la casa ancestral nuestra, cual es la tristeza mía hoy? Que esa casa nuestra, donde mi abuelo, mi madre y todos mis antepasados permanecieron, hoy la tengan de vivero de palma aceitera y desplazando a los verdaderos dueños que somos nosotros."

(Testimony of Misael Payares representative of $\mathrm{ASOCAB}$ - during the time ASOCAB's members were out of the land after eviction).

Source: Contreras and Figueroa, 2010.
English own translation:

"Our real home is Las Pavas because it is our ancestral home. What is my sadness now? That the home of ours, where my grandfather, my mother and all my ancestors stayed, it is today used as a palm nursery displacing us that are the real owners." 
Original in Spanish:

"Yo estoy acá desde el 49, allí en la tierra que era de Eliseo Payares, allí donde comienza este vivero de palma, allí estoy yo desde el 49, la creciente del año 50 la vine a pasar ahí con mi abuelo y mi padre. Es que yo soy de acá!."

(Conversation of Misael Payares representative of ASOCAB - with a congressmen on the day of the peaceful return to the land)

Source: Fundación Chasquis

Comunicación and Fundación

Contravía, 2011.
English own translation:

"I am here since 1949, there [pointing], in the land that belonged to Eliseo Payares. There [pointing], where that palm nursery starts. I have been there since 1949. I went there [pointing] to avoid the flooding of 1950 with my grandfather and my father. I am from here!."

The monoculture of oil palm for industrial palm oil production and the dramatic landscape transformations that this type of cultivation brings is considered by ASOCAB's members as incompatible with their campesino farming practices, and therefore with their identity and culture. This explains why they rejected a proposal from the El Labrador Consortium to settle the dispute. The Consortium offered to allow ASOCAB's members to exploit the land by cultivating oil palm under the model of 'productive alliances'.

Moreover, ASOCAB's members consider oil palm cultivation as a threat to the material basis of their livelihoods as it modifies the ecological basis of the territory they consider their home, in particular the wetlands and water streams that pass through Las Pavas. The following quote is illustrative:

Original in Spanish:

"Somos colombianos que vivimos en el campo y no estamos pidiendo más que un cuarto de tierra para producir alimentos y que no depreden el ambiente y acaben los humedales con palma. Si estuviéramos detrás de la plata hace rato habríamos aceptado las alianzas que nos han ofrecido los palmeros Macias y DAABON."

(Words of Misael Payares representative of ASOCAB - in an interview with a journalist (Kienyke, 2011)).
English own translation:

We are Colombians who live in the rural areas and we are not asking for more than a small parcel to produce food and that they do not damage the environment and the wetlands with the palm. If we were after the money we would have accepted the alliances that we have been offered by Macías and DAABON palm oil producers." 
The following piece of a song, composed by one of the ASOCAB' members, recounts their story telling of the landscape transformation caused by oil palm cultivation and the incompatibility with campesino way of living:

Original in Spanish:

"El desastre hecho por las palmeras, ha sido peor que una inundación porque arrasaron con la veredas que eran orgullo en mi región. Allí solo ahora se puede ver colegio sin niños y casas sin mujer, razón del destino marcado ayer pro las palmeras y el nuevo cartel."

Source: Fundación Chasquis

Comunicación and Fundación

Contravía, 2011.
English own translation:

"The disaster made by palm companies has been worse than a flood because the cleared the veredas ${ }^{16}$ that were the pride of my region. There you can only see now schools without children and houses without woman. The destiny decided yesterday by the palm companies and the new cartel."

In the case of ASOCAB's members, the material and meaning dimensions of livelihoods are linked with the capabilities dimension represented by human rights. In the lawsuits they filed against the eviction, they framed their claims in terms of human rights. By so doing, they underlined that, in the case of campesinos, the human rights that enable them to pursue the lives they value to lead depend on their access to land. ASOCAB's members used different strategies of resistance. However, resorting to the human rights jurisdiction and framing their claims in the language of human rights was a strategy that resulted in a significant achievement in terms of the protection of the multiple dimensions of their livelihoods. The highest national court under the national human rights jurisdiction decided that ASOCAB's members access to the land should be protected and ensured in order to guarantee the human rights that enable them to live according to their identity and culture.

5.4.2.2. Case 2 - The conflict between and Indupalma and ASOPRODAGRO PC (Asociación de Productores Agropecuarios y Agrícolas del Corregimiento de Puerto Carreño):

ASOPRODAGRO PC is a peasant association consisting of 64 peasant families struggling against Indupalma - a large-scale oil palm grower and palm oil producer company - in

\footnotetext{
${ }^{16}$ The spatial organization of the municipalities in rural areas in Colombia is composed of: i) the town, which corresponds to the urban zone of the municipality, and ii) corregimientos, which are located in the rural zone of the municipality. Corregimientos are divided in Veredas. The concept of veredas is not only a spatial category. It also carries social meaning. According to Forero-Álvarez (2010a), the vereda is the space rural people belong to. It represents the 'rural community'. It is the place where people undertake collective work such as maintaining or building a road or a school. It is a social entity represented by a committee composed of inhabitants of the vereda (called Junta de Accion Comunal), which develops strategies and mechanisms to establish relations with the local authorities and participate in the political life of the municipality (Forero-Álvarez, 2010a).
} 
order to maintain access to plots of land they have used for a long period of time to sustain their livelihoods. The plots add up to about 250 hectares, but they are scattered over a large area that covers several estates in which an Indupalma's oil palm plantation is located, in the Corregimiento de Puerto Carreño in the municipality of San Alberto (Map 5.1). The dispute between the members of ASOPRODAGRO PC and Indupalma has similarities with the dispute between ASOCAB and El Labrador Consortium:

i) in both cases the dispute involves a peasant association on the one side, and largescale palm oil companies or palm oil growers on the other side;

ii) in both cases the land tenure rights to the plots are contested. In the case of ASOPRODAGRO PC, the dispute started to escalate in 2002 when Indupalma started to reclaim the plots to incorporate them into one of its plantations; and

iii) the actions of resistance in both cases, especially those based on litigation, have been supported by the Corporation Development and Peace of the Magdalena Medio (CDPMM).

However, there are some differences:

i) the case of ASOPRODAGRO PC has not received as much media attention and hence visibility as ASOCAB's case;

ii) despite Indupalma's attempts at eviction, the members of ASOPRODAGRO PC have managed to maintain physical access to the plots by different strategies of resistance that range from legal actions to direct confrontation with personnel from Indupalma;

iii) the dispute in the courts has focused purely on land tenure rights, without resorting to the human rights jurisdiction;

iv) unlike El Peñon, the municipality of San Alberto is not a new frontier of palm oil expansion.

San Alberto is one of the municipalities in which oil palm cultivation first started in Colombia in the 1960s. There are about 8,500 hectares of oil palm planted and a palm oil extraction plant, which are all controlled by Indupalma. San Alberto is a palm oil enclave in which the local economy is highly dependent on Indupalma's activities. According to the documents pertaining to San Alberto's history, before the 1960s there were few settlers in the area in which San Alberto is located today. The population started to grow with the establishment of Indupalma in the area, as the company required a workforce for the plantations and the palm oil extraction plant (Fundesvic, 2011; Murcia Navarro, 2010). At present, about three-quarters of the people living in the urban zone of San Alberto $70 \%$ of 
the population) belong to families linked to the palm oil agro-industry (San Alberto's Mayor's office, no date).

ASOPRODAGRO PC's members are farmers who have long inhabited and used the contested lands for agricultural activities that are the basis of their livelihoods (group meetings with ASOPRODAGRO PC's members). Most of them are without formal titles. ${ }^{17}$ Some plots have been occupied by the same family for nearly 40 years. Others have been acquired by the current landholders from previous ones through different informal transfer arrangements such as oral negotiation or informal letters of sale called 'cartas venta' (group meetings with ASOPRODAGRO PC's members). ${ }^{18}$

The size of the plots varies from family to family, ranging from 0.5 to 7 hectares. They practise small-scale farming and raising livestock for subsistence, and they sell some of the produce in the local market. Their plots form a micro-landscape that combines the family house with a mosaic of crops and livestock (fieldwork observations). However, the plots are now enclosed by thousands of hectares of palms perfectly aligned giving a very different visual landscape. The palms are protected with signs meant to keep people other than Indupalma's personnel away. Such signs include 'poisoned area' warnings (see Picture 5.2) and a security gate at the beginning of the public road that connects both the plantation and the plots with the main road towards San Alberto town (fieldwork observations).

The members of ASOPRODAGRO PC report that since the 1960s Indupalma has expanded the plantations by occupying public lands and buying from the original settlers the public landholdings that these original settlers were occupying. As the plantations expanded, much of the original settlers' land was enclosed. As a consequence, many of original settlers sold their plots. Only a few resisted the enclosure and remained.

Since the mid-1980s, Indupalma entered into an economic crisis that precipitated the company to the edge of closure. The closure was avoided when the company embarked on a restructuring process at the beginning of the 1990s (Fadul Ortíz, 2001; Prieto Méndez, 2008). Some of the initial measures taken to overcome the crisis were reducing personnel and stopping the harvest and maintenance of about 3,000 hectares of palm (Prieto Méndez, 2008). As a consequence, there was no expansion of Indupalma's palm oil frontier during

\footnotetext{
${ }^{17}$ In group meeting with ASOPRODAGRO PC's members it emerged that only five families had formal land titles.

${ }^{18}$ The precise time of occupation changes from one family to the other. But, according to one of the leaders of the association, in all the cases it is longer than 5 years, i.e. the time required by the Colombian Agrarian Law for the campesinos to obtain land titles (Law 160, 1994. Art 69).
} 
the 1990s, and hence during that period the pressure of the company on the settlers located close to the plantations lessened (group meeting with ASOPRODAGRO PC's members).

Once the company started to recover from the crisis in 2000, it entered into a process of business renovation and development, renovating and enlarging its plantations, and expanding the palm oil frontier into neighbouring municipalities by the incorporation of new growers through 'productive alliances' (Indupalma, 2011; Fadul Ortíz, 2001; Murcia Navarro 2010; Prieto Méndez, 2008). This process was facilitated by the strong governmental support to the palm oil agro-industry during Álvaro Uribe Vélez's government between 2002 and 2010 (see Chapter 4). ASOPRODAGRO PC's members recall that it was precisely since 2002 that Indupalma's attempts to gain control over their plots started to intensify.

Once the plantations started to be renovated, ASOPRODAGRO PC's members started to come into conflict with Indupalma because some of their livestock were grazing in areas of the renewed plantations. However, Indupalma's practises of territorial control were not limited to fencing livestock out of the plantation. The company sought the control of ASOPRODAGRO PC's members' plots to incorporate them into the plantation. Indupalma resorted to a variety of means of exerting pressure on ASOPRODAGRO PC's members to compel them to leave the plots. Such means included: the establishment of a security gate; retention of ASOPRODAGRO PC's members' livestock; attempts at physical eviction (by Indupalma security personnel or with the intervention of the police); and, prohibition of Indupalma's personnel to buy products from ASOPRODAGRO PC's members.

The clashes between ASOPRODAGRO PC's members and Indupalma's security personnel escalated to the point that violent episodes occurred, such as the destruction of ASOPRODAGRO PC's members' crops and physical attacks (group meeting with ASOPRODAGRO PC's members, fieldwork interviews with key informants). ${ }^{19}$

Since 2007, both ASOPRODAGRO PC's members and Indupalma resorted to legal procedures. Indupalma filed 14 lawsuits claiming ownership over the lands, while the members of ASOPRODAGRO PC structured a legal strategy with the support of the Corporation Development and Peace of the Magdalena Medio (CDPMM). This legal

\footnotetext{
${ }^{19}$ It is important to clarify that during an interview with an executive from Indupalma, I asked if the company had had any type of conflict with local people in the areas of influence of the company. This person categorically denied that Indupalma had been involved in any conflict with local people. This closed any possibility to discuss the views of Indupalma on this conflict and the case of ASOBENPRO (Section 5.4.2.3).
} 
strategy included the defence against Indupalma's lawsuits and the filing of titling processes for 32 plots of ASOPRODAGRO PC' members (Beltrán Ramírez, 2008).

The Lower Court dismissed Indupalma's lawsuits in 2010 (Juzgado Promiscuo del Municipio de Aguachica-Cesar, 2010; La Silla Vacía, 2010).

By the time of the last communication with ASOPRODAGRO PC's members (June 2012), the titling processes were still pending.

Most of ASOPRODAGRO PC's members live on the contested plots and combine a series of land-based subsistence and productive activities that constitute the material dimension of their livelihoods. ${ }^{20}$

As in the case of ASOCAB, ASOPRODAGRO PC's members connect their living on, and making a living out of, the land with the culture and identity of the campesino, which they consider non compatible with the cultivation of oil palm, as they express in the following quotes:

Original in Spanish:

"Mire, anduvimos tres kilómetros, palma palma, palma. $Y$ donde se produce el alimento, así que es el directo, digamos plátano, la yuca, las gallinas, es poquitica el área que hay de terreno. Entonces eso es preocupante, es que es preocupante porque nosotros los campesinos no vamos a cortar el gajito de corozo - lo he dicho como 20,000 veces - y vamos a cocinarlo y a solucionar el desayuno, el almuerzo o la comida, no."

(Group meeting with members of ASOPRODAGRO PC)
English own translation:

"Look, in these three kilometres we made [refereeing to the journey I did together with one of the leaders to arrive at one of their plots] palm, palm and palm. And, where the food, direct food, is produced - I mean plantain, cassava, chicken - is a very small area now. That is worrying, because we, the peasants, we are not going to cut oil palm fruit - I have said this 20,000 times - and cook it and have breakfast, lunch or dinner, no."

${ }^{20}$ According to a database with the characterisation of the members of ASOPRODAGRO PC obtained from a key informant during the fieldwork, about three quarters of ASOPRODAGRO PC members have their houses on their plots. 
Original in Spanish:

"es una cultura, nosotros no queremos hacer más nada... sembrar comida y que haya comida para nosotros y lo que sobre para los vecinos, que haya para llevar a otras regiones donde no haya... Si me gustara sembrar palma, ya hace muchos años la hubiera sembrado porque es que mi cultura es sembrar comida. Desde niño, desde allá que yo me acuerde que tenga memoria, desde allá, toda la vida hemos venido así, sembraba mi abuelo, sembraba mi papá, ahora siembro yo, tengo una hija de 10 años y ella ahora también cuando está aquí siembra sus matas porque eso es lo que se lleva, eso va de cuna."

(Group meeting with members of ASOPRODAGRO PC)
English own translation:

"This is a culture, we do not want anything to do other than cultivate food and produce food for ourselves, and what remains for the neighbours, and make food available to bring to other regions where there is none... If I would like to grow palm, I would have done it years ago, but my culture is to cultivate food. Since I was a child, since I remember, since I have memory, since then, we have done it forever. My grandfather used to cultivate, my father also. I cultivate now. I have a 10 years old daughter. When she is here she cultivates her plants. Because we have that within us, that was born with us."

It was because of the interrelation between the campesino identity and the material practices of subsistence attached to it, that ASOPRODAGRO PC's members refused the offer of a land assignment from the governmental agency in charge of processing their land titling requests. ASOPRODAGRO PC's members recount that the land assignment was subject to two conditions: quitting their claims in the plots in San Alberto and growing palm in the lands to be assigned in a 'productive alliance' with Indupalma.

The incompatibility of oil palm cultivation with campesino identity and practices is illustrated by the following quote about the rejection of the offer: "it did not make any sense, they wanted to change our way of life by force", "they were going to kill us twice by taking over our lands and putting us to grow palm under the company direction" (Group meeting with members of ASOPRODAGRO PC). ${ }^{21}$

\footnotetext{
${ }^{21}$ Original quotes in Spanish: "no tenía como sentido, nos querían cambiar de vocación a la fuerza". "No nos iban a matar sino a contramatar, nos quitan lo de nosotros y nos ponen a sembrar palma y ella [Indupalma] nos maneja".
} 
The meaning dimension of livelihoods in the case of ASOPRODAGRO PC' members, as in the case of ASOCAB, is grounded, not only in the campesino identity and culture, but also in their personal attachment to the land. They also articulate their relation with the land in terms of 'belonging', and hence they frame the dispute with Indupalma in these terms, as the following quotes illustrate:

Original in Spanish:

"La empresa nos ha llamado invasores, y le digo que no, que la invasora es la empresa que llego de fuera, nosotros somos de aqui del territorio."

"Nosotros somos de acá de esta zona. Nosotros somos de acá. nunca podemos ser invasores. Yo creo que por el hecho de los padres de nosotros nacer acá y nosotros nacer acá tenemos algún derecho. Acá nos hicieron, acá nacimos, aquí estamos y si Dios quiere moriremos de viejos acá."

(Group meeting with members of ASOPRODAGRO PC)
English own translation:

"The company has called us invaders, and I say no, the invader is the company that comes from elsewhere, we are from here, from the territory."

"We are from here, from this area. We are from here. I think that because our parents were born here and we were born here, we have some rights. We were conceived here, we were born here, we are here, and if God wants so, we are going to die here."

ASOPRODAGRO PC's members do not frame their claims explicitly in terms of human rights, as ASOCAB do. However, the capabilities dimension of their livelihoods emerges from the reference to the threats that the expansion of palm oil cultivation represents for their ability to live as campesinos, i.e. threats to produce food for subsistence and income generation, to live on the land, to decide what and how to farm, and to be able to participate on the decisions concerning what their consider their territory.

Such threats materialise not only in the land control practices of the palm oil companies, but also in the transformation of the local environments that sustain people's livelihoods. As in the case of ASOCAB, ASOPRODAGRO PC's members connect the expansion of oil palm cultivation with a transformation of the landscape that limits their access to land due to the exclusionary character of oil palm plantations, as expressed in the following quotes: 
Original in Spanish:

"Las palmas ellas viven solas, es decir, todo árbol que este dentro de la palma, tiene que cortárselo, árboles nativos, para que ellas se puedan desarrollar. Entonces yo he sacado una conclusión, yo digo, estos cultivos y los dueños son iguales, ellos quieren extinguir todo el que habite ahí.. La palma hace desaparecer veredas. Únicamente quedarían, si la suerte es buena, los corregimientos. Este corregimiento tiene una característica no tiene veredas. ¿Por qué no tiene veredas? Porque todo está poblado en palma."

"Esta zona era rica en pescao. Usted iba y tiraba la atarraya allá, y vea, si le iba mal, sacaba 10 - 15 pescaos cuantas veces la lanzara. Ahora solo quebradas por donde pasan esos cultivos. Se dieron a la tarea de canalizar, destruir todos los bosques que habian nativos, ahora quedaron quebradas como hacer una quebrada por la mitad de la carretera." (Group meeting with members of ASOPRODAGRO PC)
English own translation:

"Palms live alone, I mean, any tree standing where the palms are has to be cut - native trees -, so the palms can grow. Thus, I have concluded that these crops and their owners are alike, they want to extinguish all what dwells where they are... The palms cause the disappearance of the veredas. Only the corregimientos will remain if we are lucky. This corregimiento has a characteristic, it does not have veredas. Why does not it have veredas? because it is filled with palm."

"This area was rich in fish. If you threw the net there you could catch 10 or 15 fish as many times as you threw it. Now, there are only water channels where those plantations are. They canalised water streams and destroyed the native forest. Only water channels were left, it is like making a water channel in the middle of a road."

\subsubsection{Case 3 - ASOBENPRO (Asociación de Beneficiarios del Proyecto the Palma El}

Progreso) Vs Indupalma:

As the transformation of the landscape for oil palm expansion is reaching its geographical limits in the municipality of San Alberto, Indupalma is expanding its frontier towards neighbouring municipalities of Sabana de Torres and Puerto Wilches, and even to other regions within the palm oil geography $(5,000$ hectares in the East Region of the palm oil geography).

Indupalma built a palm oil extraction plant called Oro Rojo in the municipality of Sabana de Torres (see Map 5.1). The plant has a large processing capacity - 60 tonnes of oil palm fresh fruit bunches (FFB) per hour (Indupalma, 2009). The company has expanded the frontier in that municipality through the establishment of 'productive alliances'. The palm oil plant was built in the location called vereda La Moneda. This is the same site where the lands of a estate called La Pampa are located. In October 2007, the government decided to assign the lands of La Pampa to a group of 115 families in a situation of forced internal 
displacement. The assignment was accepted by 90 out of the 115 families. ${ }^{22}$ The assignment of the land was conditional on the obligation of growing oil palm in the estate.

The families that moved to La Pampa formed the association ASOBENPRO for the management of oil palm project and the collective tenure of the land. The government provided the seed capital to establish the plantation and selected an organisation that would act as the operator of the project to provide the necessary technical assistance and support to ensure the proper establishment and development of the plantation in both economic and agronomic terms. The operator chosen by the government was Indupalma.

Indupalma was in a favourable position for, and had an obvious interest in, becoming the operator of the project for two reasons. First, it had experience in the palm oil agri-business in the region. Second, the location of La Pampa would facilitate the supply of the raw material (oil palm fresh fruit bunches) to the Oro Rojo extraction plant. Indupalma was selected by the government as the operator of ASOBENPRO's oil palm project on the basis of the 'productive alliances' business model it had designed and already tried in the region (see Chapter 3 for a more detailed description of 'productive alliances' business model).

Conversely, the members of ASOBENPRO did not have other option other than growing oil palm if they wanted to be beneficiaries of the land assignment. Moreover, they were not involved in the decision-making process about the operator and the model under which the oil palm project should be carried out. Once they came to know the conditions of Indupalma's model in October 2008, some of the ASOBENPRO's members started the resistance. Indupalma's model implied that the land had to be cleared for the plantation, i.e. no people could live on the land and they would be re-located in a neighbourhood of the town of Sabana de Torres. This meant that ASOBENPRO's members would keep land tenure rights but they would have no control over the land, and they could not decide on the farming practices used on the land.

This was the breaking point for those members of ASOBENPRO that came from the campesino tradition. They rejected the model of Indupalma and in so doing entered into conflict with the company and the government (group meeting with members of ASOBENPRO; Defensoría del Pueblo, 2011: Anexo I; Ramón Jácome, 2010).

Due to their vulnerable situation as displaced people, they faced the trade-off between gaining and maintaining access to land, which was conditional on the cultivation of palm,

\footnotetext{
${ }^{22}$ The exact number of families that were living in La Pampa at the moment of the fieldwork was not clear. Although 90 families received the lands, during the interviews and group meetings it was said that only 65 were present in La Pampa.
} 
and their campesino identity, which was not compatible with the model of cultivation imposed by Indupalma. Thus, the resistance of ASOBENPRO's members is articulated in terms of campesino identity as well as both the farming practices and the relation with the land connected with that identity.

The opinion of one of the key informants for this case is illustrative of this misfit between the campesino identity of ASOBENPRO's members and the 'productive alliance' model of oil palm cultivation proposed by Indupalma: "the model was built upon the wrong assumptions. They are not entrepreneurs and were not willing to capitulate their worldview...that model disregards other worldviews...they do not define themselves like that...they want to live in the territory" (interview with a lawyer who represents ASOBENPRO in land tenure legal procedures). ${ }^{23}$

Thus, Indupalma's model represented a form of 'assimilation' that entailed the disarticulation of the different dimensions of campesino livelihoods and failed to recognise the campesino identity, as expressed by a member of ASOBENPRO: "what they did [referring to Indupalma] was to ignore us and discriminate us" (member of ASOBENPRO quoted in Ramón Jácome, 2010: 54). ${ }^{24}$ Under Indupalma's model of 'productive alliance' the land is disarticulated from the identity by forcing farming practices and ways of living that are at odds with the campesino culture. ASOBENPRO members were going to be forced to live away from the land, so losing the possibility to practice land-based activities such as growing food in their backyards or livestock raising, which are part or campesino culture. Their resistance was thus in defence of their 'lifeworlds', and the ability to decide on what to do with the land and how.

ASOBENPRO's members managed to find an operator that would support the oil palm project respecting their basic demands, i.e. the ability to live in the land and keep a piece of it for growing food crops and having livestock. The support came, as in the other two cases, from the Corporation Development and Peace of the Magdalena Medio (CDPMM).

CDPMM has a programme to support associations of small-holding farmers in the establishment and managements of oil palm projects under a model different from that proposed by Indupalma. CDPMM's model is called Finca Campesina con Palma (peasant farm with palm). Under such a model farmers with small-holdings of minimum 10 hectares devote a portion of their land to grow oil palm and form an association with other farmers

\footnotetext{
${ }^{23}$ Original quote in Spanish: "el modelo estaba montado sobre supuestos equivocados. Estos no son empresarios y no están dispuestos a capitular su manera de ver el mundo...ese modelo desconoce otra maneras de ver el mundo...ellos no se identifican así...ellos quieren vivir en el territorio".

${ }^{24}$ Original quote in Spanish: "Lo que hicieron fue desconocernos y discriminarnos".
} 
who are also involved in the programme in the same municipality (in the case of a 10 hectares farm, the portion devoted to palm is maximum of eight hectares).

The association functions as a mechanism of management through which the small growers jointly commercialise the oil palm fresh fruit bunches (FFB) they harvest and negotiate the prices of transport and agricultural inputs. The small-holding growers have access to technical, administrative, financial and legal assistance through the associations provided by an umbrella organization - Fundepalma. Fundepalma was created by the CDPMM to manage the programme Finca Campesina con Palma (fieldwork interviews and observations; Fundepalma, 2011). Fundepalma also assists the associations in applications for credit and subsidies financed by the government.

Under the CDPMM's model, the small-holding growers can live on the land and can use the remaining part of their parcels of land for subsistence activities other than oil palm cultivation (for example livestock raising and cultivation of subsistence crops). Thus, under such a model, the participants can establish and manage small plantations in a way that is closer to their campesino culture and traditional farming practices, and they are not subject to the control of a specific palm oil producer. This is expressed in the following quote from a member of ASOBENPRO about the Finca Campesina con Palma programme: "this [programme] it is focused on what we want and respects our campesino way of being" (member of ASOBENPRO quoted in Ramón Jácome, 2010: 52). ${ }^{25}$

Some of the associations of small growers belonging to the Finca Campesina con Palma programme have reached the productivity levels expected for large plantations that have the same age according to the national average of productivity defined by Cenipalma (the Oil Palm Research Centre). ${ }^{26}$ This demonstrates that small-holding growers can be as productive as large-scale growers.

5.4.3. The livelihood and justice dimensions of resource access struggles and the emancipatory potential of human rights

The cases analysed in this chapter show that under the expansion of the palm oil frontier agrarian processes of dispossession have converged with grievances resulting from the transformation of the environments local people depend upon. This convergence has

\footnotetext{
${ }^{25}$ Original quote in Spanish: "este [programa] sí está enfocado en lo que queremos nosotros y respetan nuestro ser campesino".

${ }^{26}$ This is the case of ASOPALVI in the municipality of San Vicente del Chucurí and ASOPALMAR in the municipality of San Martín. ASOPALVI produced 12.6 tonnes of FFB per hectare in the fifth year. ASOPALMAR produced 20 tonnes of FFB per hectare in the seventh year (Fundepalma, 2011; Cecodes, 2010). The national average of expected productivity for the fifth year and the seventh year as defined by Cenipalma are 12 and 20 tonnes of FFB per hectare, respectively (Cecodes, 2010).
} 
occurred in such a way that it is not only the material basis of livelihoods that is at stake, but also local people's 'lifeworlds' and the freedom to conduct the lives they value to lead in light of such 'lifeworlds'.

The members of ASOCAB, ASOPRODAGRO PC and ASOBENPRO recount how the interrelated dimensions of their livelihoods are affected by two types of threats to land access arising from the expansion of the palm oil frontier. First, the threat of physical dispossession from the land, and second, the transformation of landscapes and 'lifeworlds' that oil palm cultivation entails. That explains why they oppose the expansion of the palm oil frontier that threatens the environments that sustain their campesino livelihoods and identity. That also explains why they rejected the offers to gain or maintain access to land to grow oil palm in association with palm oil producers under the form of 'productive alliances'. Thus, from the languages of contestation of the members of ASOCAB, ASOPRODAGRO PC and ASOBENPRO emerge the different dimensions of livelihoods dependent on access to land. Land is not simply a means through which they make a living. It also gives meaning to their world, and gives them the capability to be and to act in light of that meaning (Bebbington, 1999).

The multiple dimensions of land-based livelihood that the members of ASOCAB, ASOPRODAGRO PC and ASOBENPRO articulate in their languages of contestation convey the multiple and interrelated dimensions of Schlosberg's pluralistic justice approach (Schlosberg, 2007). Equity in the distribution of land in order to be able to meet subsistence and income generation needs is the first dimension.

The second dimension is the recognition of the campesino culture and identity that shapes and is shaped by campesinos' relation with land and the "formation of place", i.e. what they do on, and with the land, and how they do it (Bebbington, 2004). The romantic image of the campesino whose productive activities are totally dependent on land and natural resources has been highly contested. It has been demonstrated that campesinos rely on both on-farm and off-farm activities to make a living (Bebbington, 1999, Forero-Álvarez, 2002).

Some members of ASOCAB, ASOPRODAGRO PC and ASOBENPRO derive part of their income from off-farm activities. However, they consider themselves campesinos as they are connected with the land. That connection with the land, what they do with the land and how they do it is the source of their campesino identity.

This identity, however, does not exclude the reality of off-farm activities as sources of income. This coincides with the conclusions of the studies of Ploeg (2008) about the peasantry and the studies of Forero-Álvarez on campesino agriculture in Colombia. In the 
case of Colombia, Forero-Álvarez has found that the campesino identity is defined by the relation campesinos establish with the land and the rural community they belong to, regardless of the fact that they combine in-farm activities with off-farm jobs (ForeroÁlvarez, 2002).

According to Forero-Álvarez, "peasants are family farmers (or family farm workers) who think of the soil not only as a productive asset, but also as part of their cultural heritage (physical or symbolic) and who belong to and are an active part of their rural communities" (Forero-Álvarez, 2013: 29).

Thus, what Tania Li concluded about self-identification resulting from her studies on indigenous people's identity in Indonesia is also applicable to campesinos. According to $\mathrm{Li}$ "a group's self-identification is not natural or inevitable, but neither is it simply invented, adopted, or imposed. It is, rather, a positioning which draws upon historically sedimented practices, landscapes, and repertoires of meaning, and emerges through particular patterns of engagement and struggle" (Li, 2004: 309).

Thus, the cases analysed in this chapter demonstrate that the inextricable relation between land and campesino identity is not a romantic ideal. The empirical evidence demonstrates otherwise. Unpacking such a relation is analytically relevant to understand the different livelihood dimensions of the campesino population, and the dimension of justice compromised when their land access and 'lifeworlds' are threatened.

Interrelated with the distribution and recognition dimensions of justice is the capabilities dimension. This means that the recognition of campesino identity and culture entails guaranteeing the freedoms that enable campesinos to be and act as such, i.e. freedom to work on the land, freedom to produce food for subsistence and income generation, freedom to live on the land, freedom to enjoy a healthy environment. In order to guarantee the other three dimensions of justice, participation in the decision-making about projects and activities that affect the territories they inhabit and depend on needs also to be ensured.

Thus, the different dimensions of justice are interrelated. Therefore, dispossessing campesinos from the material basis of their livelihoods, either through direct dispossession from the land, or through transformation of the environments they depend upon without their consent - such as in the cases of ASOCAB's and ASOPRODAGRO PC's members results in grievances related to distribution, recognition, capabilities and participation.

Moreover, the imposition of a trade-off between land access and campesino 'lifeworlds' through 'assimilation' strategies - such as in the case of ASOBENPRO - results in the 
disarticulation of livelihoods dimensions, so compromising the realisation of justice in its different dimensions: recognition, capabilities and participation. As the different dimensions of justice are interrelated, "one is never to be considered a replacement for the others" (Schlosberg, 2007: 171-172).

In none of the three cases presented in this chapter, have the members of the peasant associations been passive victims. Conversely, they have been agents of resistance, so putting their power into action to counteract the power exerted by palm oil companies. Although, they have resorted to both legal and de facto means of resistance, the case of ASOCAB demonstrates the potential of the human rights normative framework to articulate multiple dimensions of justice for emancipatory politics. Framing their struggle in terms of human rights and resorting to the human rights jurisdiction resulted in a decision by the highest court in Colombia recognising the different dimensions of livelihoods, so contributing to the realisation of the multiple dimensions of justice.

The case of ASOCAB demonstrates that the 'constellation of local meanings' (Santos, 2002) and application of the human rights normative framework in specific contexts may be shaped by the way in which excluded, unrecognized or silenced individuals or groups articulate their struggles for the realisation of the different dimensions of justice.

The decision of the Constitutional Court recognising that the realisation of the human rights of the ASOCAB's members depends on the respect for, and defence of, the different dimensions of their land-based livelihoods, is a remarkable political achievement for the attainment of the different dimensions of justice.

This court decision safeguarded the material access to land that allows a particular way of being and living, and by so doing it conveyed "new meaning about the dignity and political potential" of the campesino population (Bebbington, 2004: 184). ASOCAB's political action and its outcomes represent a challenge to the foundations of access to land in Colombia.

Thus, the case of ASOCAB demonstrates the emancipatory power of the human rights framework for social actors that convey different dimensions of justice in their struggles for the defence of their livelihoods against the expansion of commodity frontiers.

In Fig. 5.2 I place the results of the analysis of the three cases presented in this chapter in the analytical framework presented in Fig. 5.1. Thus, Fig. 5.2 shows how the human rights framework, the multiple dimensions of justice and the multiple dimensions of livelihoods interrelate in the cases presented in this chapter. 
Fig. 5.2. Interrelations between land access struggles connected with the expansion of the palm oil frontier in Colombia, dimensions of livelihood, dimensions of justice and human rights

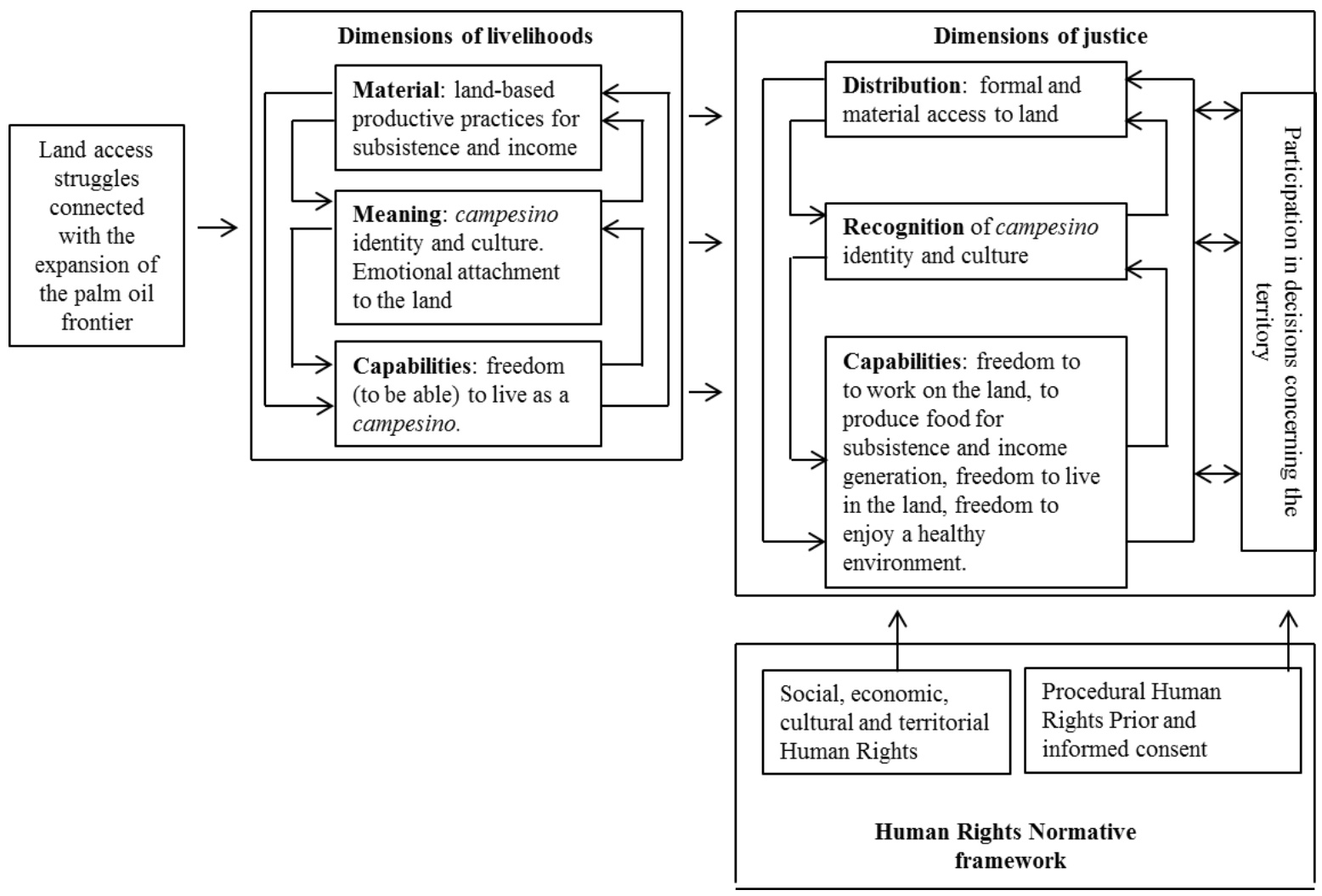

Source: own construction. 


\subsection{Conclusions}

In this chapter I set out to:

i) identify the multiple dimensions of justice compromised when expansion of commodity frontiers threatens local people's access to the resources that sustain their livelihoods and takes away their identity, and

ii) explore the emancipatory potential of the human rights framework as an instrument of resistance against the expansion of commodity frontiers.

The three cases analysed in this chapter show that for local people involved in struggles for access to resources, the multiple dimensions of their livelihoods (material, capabilities, and meaning understood as identity and sense of belonging) are dependent on that access.

In the three cases, the land is considered by the members of the campesino associations not only as the material basis for subsistence and income, but also as the basis of the campesino 'lifeworld' and a source of capabilities to be and act as campesinos. The way in which the members of the campesino associations value their land and territory is in clear conflict with the way in which the palm oil companies articulate value regarding the contested lands. Thus, "different social groups experience places in different ways, depending on their particular interests" (Bebbington, 2004: 180). Although it seems an obvious observation, it has important implications in terms of justice. What is at stake for the members of the campesino associations is not an economic asset for capital accumulation, but their means of subsistence, their identity and the rights that enable them to pursue the lives they value to lead. Thus, the multiple dimensions of livelihoods that emerge from the languages of contestation in the three cases analysed in this chapter demonstrate that also multiple dimensions of justice - distribution, recognition, capabilities and participation - are at stake in resource access struggles and socio-environmental conflicts connected with the expansion of commodity frontiers. Moreover, the three cases show that local people are not passive victims of such expansion and the injustices it represents, but they have agency, which they translate into resistance. From the different strategies of resistance adopted by the three campesino associations, the positive outcome in terms of land access that ASOCAB achieved by resorting to the human rights framework and jurisdiction demonstrates the emancipatory potential of this framework. The emancipatory outcome was rooted in an application and interpretation of the human rights framework that embraced the constellation of local meanings represented in local people's livelihoods and identities.

From the analysis presented in this chapter is possible to draw some conclusions about how the dimensions of justice are threatened in practice and defended through the politics of 
human rights in cases of local resistance connected with the expansion of commodity frontiers.

Firstly, the expansion of commodity frontiers entails not only the dispossession of the material basis of livelihoods. The socio-environmental transformations produced by such expansion also entail the dispossession of identity and capabilities. As a new landscape is produced, so do 'lifeworlds' and meanings attached to place (Bebbington and Batterbury, 2001: 375). Material, identity and cultural dispossession, in turn, weaken the capabilities of local people to pursue the lives they value to live. This means that the expansion of commodity frontiers without the consent of the local people concerned, compromises the different dimensions of justice.

Secondly, local populations are not passive victims of the expansion of commodity frontiers and the injustices it represents, but they use their agency to exert power through resistance. However, the potential of resistance to overcome the grievances depends on the mechanisms used. Often, local people resort to different mechanism in parallel, as in the three cases analysed in this chapter. Without dismissing the importance of other forms of resistance, the case of ASOCAB shows that the human rights framework is an instrument of resistance with significant emancipatory potential. The simultaneous engagement with distribution, recognition and capabilities dimensions of justice through legal action grounded in the human rights framework created a precedent with significant political implications for the defence of access to land of the campesino population. Thus, the case of ASOCAB shows how the human rights framework is a powerful instrument to articulate the multiple dimensions of justice in defence of the multiple dimensions of livelihoods threatened by the expansion of commodity frontiers. However, the emancipatory potential of human rights politics depends on how the human rights framework is applied and constructed. The case of ASOCAB demonstrates that human rights politics produces emancipatory outcomes when the application and interpretation of the normative framework reflect the local meanings of marginalised and silenced groups. This way of applying and interpreting human rights corresponds with Santos's 'multicultural conception of human rights' (Santos, 2002 and 2007). 


\section{Chapter 6}

\section{Contesting Legitimacy of Non-state Market-driven Sustainability Governance: Valuation Languages and Procedural Power in the Roundtable on Sustainable Palm Oil in Colombia}

This chapter is based on:

Marin-Burgos, V., Clancy, J.S., Lovett, J.C., 2014 (in press). Contesting legitimacy of Voluntary Sustainability Certification Schemes: valuation languages and power asymmetries in the Roundtable on Sustainable Palm Oil in Colombia. Ecological Economics (2014), http://dx.doi.org/10.1016/j.ecolecon.2014.04.011.

\subsection{Introduction:}

In this chapter I address Research Sub-question 4 of this dissertation: How do power asymmetries among local actors and differences in values deployed in national standardsetting processes influence legitimacy contestation of NSMD sustainability governance systems at the national scale?

Voluntary certification schemes aimed at ensuring producer compliance with a set of sustainability criteria have emerged as market-based governance responses to concerns about socio-environmental impacts of industries based on agricultural, forest, mineral or marine resources. These schemes constitute innovative forms of global sustainability governance beyond the state (Arts, 2006; Bernstein, 2005; Cashore, 2002; Pattberg, 2005, Take, 2012). They are market-based instruments of governance, operating within broader governance systems that fall into the specific category identified by Cashore, (2002) as nonstate market-driven (NSMD) governance systems, i.e. "deliberative and adaptive governance institutions designed to embed social and environmental norms in the global marketplace that derive authority directly from interested audiences, including those who seek to regulate, not from sovereign states" (Bernstein and Cashore, 2007: 348). ${ }^{1}$ Legitimacy is a major concern when dealing with this type of governance system and has become a focus for research (Bäckstrand, 2006; Bernstein, 2005; Bernstein and Cashore, 2007; Biermann and Gupta, 2011). This concern is grounded in two characteristics: i) there is neither electoral nor representative legislative processes, which are the sources of legitimacy for rule-making in national democracies (Bäckstrand, 2006; Tamm Hallström

\footnotetext{
${ }^{1}$ A NSMD governance system encompasses the entire institutional apparatus underlying the adoption and implementation of a NSMD governance mechanism, which includes the NSMD governance mechanism itself.
} 
and Boström, 2010), and ii) these governance systems involve many issue areas affecting different groups of actors at different scales (Bernstein, 2011). However, due to their market-driven nature, these governance systems may not be responsive to issues beyond the need for consumer confidence and commercial viability (Klooster, 2010).

Most socio-environmental effects that NSMD governance systems seek to address are experienced locally, such as alteration of environments that sustain local peoples' livelihoods, and have negative impacts on access to natural resources. Such effects are often at the centre of socio-environmental conflicts, i.e. conflicts over access to natural resources and over the burdens of environmental impacts, that are rooted in differences in values and inequalities in power and wealth among human groups (Escobar, 2006a; Martinez-Alier, 2002). Typically, local actors involved in such conflicts have opted for self-exclusion from the industrial commodity chain because participation does not fit with their values (Hospes and Clancy, 2011). Thus, they are stakeholders that may grant or contest legitimacy, depending on how their values are reflected and power is mobilised in processes that are used to develop sustainability criteria. ${ }^{2}$ Legitimacy of NSMD systems in relation to these local actors is important for two reasons. Firstly, because it increases the chances that they will participate in the decision-making and implementation processes, thereby ensuring that social and environmental impacts that affect them are actually taken into account. Secondly, because legitimacy contestation by local actors undermines the potential of NSMD systems to protect business actors who participate in such systems, because they consider that participation in the system protects them from naming and shaming boycott campaigns (Cashore et al., 2004; Nikoloyuk et al., 2010).

However, granting of legitimacy by local actors involved in socio-environmental conflicts has not been the subject of extensive empirical research. Much of the work on legitimacy of NSMD sustainability governance instruments and systems uses a priori legitimacy criteria (Risse, 2006; Bäckstrand, 2006; Take, 2012) and focuses on how internal governance and the standard-setting processes are structured and developed at the international level (Auld and Gulbrandsen, 2010; Klooster, 2010; Partzsch, 2011; Schouten and Glasbergen, 2011). This type of approach is not well suited to exploring how legitimacy is actually granted or contested in a specific local context. Therefore, in this chapter, I adopt Bernstein's concept

\footnotetext{
${ }^{2}$ The local actors that resist extractive activities include individuals, communities, and civil society organizations. These actors are not a homogeneous group. They differ between the categories of actors and also within categories. They may hold different positions and interests, and pursue different objectives, which may even conflict. Therefore, I am aware that categories such as local communities, civil society organizations and local actors are contested. However, for analytical purposes in this chapter I use the category of local actors to refer to individuals, communities and civil society organizations that resist the expansion of industrial oil palm cultivation and contest legitimacy of the RSPO.
} 
of legitimacy as acceptance of a rule by 'relevant audiences' as appropriate and justified (Bernstein, 2005 and 2011; Bernstein and Cashore, 2007). ${ }^{3}$ Most empirical analyses based on this notion of legitimacy focus either on legitimacy granting by actors within the commodity chain (Cashore et al., 2004; Cashore et al., 2007), or on the international dimension of NSMD mechanisms (Schouten and Glasbergen, 2011; von Geibler, 2012). ${ }^{4}$ Very few studies have included local actors in their analyses (Johansson, 2012; McDermott, 2012). To fill this gap, research on perceptions of legitimacy is needed at the local level to broaden understanding of legitimisation processes (Schouten and Glasbergen, 2011; Bernstein and Cashore, 2004).

This chapter's objective is twofold. Firstly, to explore how different values and power deployed in national processes of sustainability criteria development influence legitimacy granting or contestation by local actors involved in socio-environmental conflicts, and secondly, to contribute to the study of legitimacy of NSMD sustainability governance systems, by integrating concepts from ecological economics and political ecology into the analysis of legitimacy dynamics of acceptance or contestation at the national scale. To do so, I analyse the process of adoption of the Colombian National Interpretation of the Roundtable on Sustainable Palm Oil (RSPO) Principles and Criteria by combining the legitimacy literature based on critical sociology with the concepts of valuation languages and 'procedural power'.

Global palm oil production and consumption have increased at an accelerated pace since 2000 , becoming the world's most consumed vegetable oil in 2005 . World demand for palm oil increased sharply in the period 1995-2010 (+32 million tonnes). In 2010, 46.8 million tonnes of palm oil were consumed (MVO, 2010). Global production increased from 21.8 million tonnes in 2000 to 45.8 million tonnes in 2010 (Oil World, 2001 and 2011). The RSPO was formed in 2004 as an initiative of Unilever and the World Wildlife Fund (WWF), to respond to sustainability concerns associated with the accelerated growth of the palm oil industry worldwide. ${ }^{5}$ The generic RSPO Principles and Criteria (RSPO P\&C) were released in 2007 as approved for use, while the certification system was adopted in 2008. As a condition for certification of local producers, the RSPO system requires a national interpretation of the international RSPO P\&C to be carried out in the producer countries (RSPO, 2007). ${ }^{6}$ None of the research studies on the RSPO found by the author focuses on

\footnotetext{
${ }^{3}$ See Section 6.2 for Bernstein's definition of 'relevant audiences'.

${ }^{4}$ See Chapter 2 for the definition of 'commodity chain' used in this dissertation.

${ }^{5}$ Unilever is a multinational company that produces food, cosmetic, and household care goods. Since palm oil is one of the raw materials used to produce these consumer goods, Unilever is an important buyer of palm oil in the international market

${ }^{6}$ If a national interpretation process has not been carried out in a specific country when a producer seeks certification, the international RSPO P\&C will be applicable. "Where the international RSPO
} 
national interpretation processes (Castañeda-Silva, 2011; Hospes, 2011; Nikoloyuk et al., 2010; Partzsch, 2011; Pesqueira and Glasbergen, 2012; Schouten and Glasbergen, 2011 and von Geibler, 2012). Colombia is particularly interesting for this type of study because most of the palm oil production sustainability concerns relevant for local actors are at the core of socio-environmental conflicts. Colombia is the fifth-leading palm oil producer in the world and first in the Americas. Increasing palm oil production in the country has entailed an accelerated expansion in industrial cultivation of oil palm, especially since the year 2000 . The land area devoted to oil palm increased from 157,000 hectares in 2000 to 404,000 hectares in 2010 (Fedepalma, 2005 and 2011a), and this growth has been accompanied by cases of socio-environmental conflicts between the agro-industry, and peasants or AfroColombian communities. There is also substantial opposition to expansion of oil palm cultivation from several civil society organizations. At the core of these conflicts there are sustainability concerns related to alteration of ecological and environmental characteristics; and modification of land access arrangements in areas considered by rural dwellers to be their territories. The palm oil industry represented by Fedepalma (National Federation of Oil Palm Growers) responded to the social and environmental concerns by: i) becoming a member of the RSPO, and ii) paving the way for producer certification through adoption of the Colombian National Interpretation of the generic RSPO P\&C (NI). Although the NI process was meant to develop the generic RSPO P\&C in accordance with local concerns through a participatory process that included several stakeholder meetings, the RSPO system and the certification mechanism have been strongly contested by local actors. Therefore, analysing the case of the NI process in Colombia sheds light on how legitimacy granting or contestation by local actors is shaped by the way values and power are deployed in national processes of sustainability criteria development.

This chapter is structured as follows. In Section 6.2 I explain the conceptual framework used to integrate the concept of legitimacy with those of valuation languages and 'procedural power', thereby enabling analysis of legitimacy dynamics of NSMD sustainability governance systems. Section 6.3 introduces the background of the RSPO and the NI in Colombia and contains a description of the data collection methods. Sections 6.4 and 6.5 contain the analysis of the National Interpretation (NI) process of the RSPO P\&C in Colombia and the discussion about its implications for the legitimacy of RSPO in Colombia. Section 6.6 presents the conclusions.

Criteria are being used, the certification body must develop local indicators through a consultative process, available in the local language" (RSPO, 2007: 18). 


\subsection{Legitimacy, plurality of values and 'procedural power' in NSMD sustainability governance}

Bernstein's conceptualization of legitimacy underpinning our analysis states that "legitimacy always rests on shared acceptance of rules and rule by affected groups, who constitute the community that grants legitimacy and on the justificatory norms they recognize" (Bernstein 2011: 21; Bernstein, 2005; Bernstein and Cashore, 2007). Bernstein refers to the affected groups as 'relevant audiences', and his approach acknowledges that legitimacy requirements of global governance schemes depend on the "historically contingent values, goals, and practices" of such 'relevant audiences' (Bernstein, 2011: 24). Therefore, to understand legitimacy dynamics at the national scale, substantive and procedural legitimacy requirements need to be investigated empirically with respect to both national 'relevant audiences' and national processes used to develop the international standard.

The substantive legitimacy requirements on the basis of which 'relevant audiences' grant or contest legitimacy lie in both the core values of the 'relevant audiences' and the interaction of 'relevant audiences' values with the values and goals that the governance system represents and promotes. In the case of NSMD sustainability governance systems, the 'relevant audiences' are broad and varied "in terms of identities, geographic location, and interests" (Bernstein, 2005: 164; 2011; Cashore, 2002). They may hold diverse and even conflicting core values, not only between each other, but also with respect to the values that the governance system represents and promotes, i.e. normative divergence or contestation. Substantive normative divergence or contestation may emerge when the social and environmental negative impacts that NSMD governance mechanisms aim to tackle, constitute arenas of socio-environmental conflict at the local level. This is because local actors involved in the conflicts are at the same time 'relevant audiences' of the NSMD governance system. Due to the particular market-based nature of NSMD governance mechanisms, local actors' normative contestation may be rooted in concerns about the appropriateness of NSMD governance mechanisms to deal with the tension between market values and local actors' socio-environmental values (Guthman, 2007; Klooster, 2010; McAfee, 1999; Taylor, 2005). The market-based nature of the mechanism implies that producers will adhere to a sustainable behaviour, because of market pressures or rewards in the form of market access or price premiums (Bernstein and Cashore, 2007; Cashore, 2002). This requires the existence of a market for sustainable products (Ponte, 2012), so that the continuous growth of the industry remains uncontested. This is questioned by some 'relevant audiences' who hold social and environmental values, as shown by empirical evidence (Elgert, 2012; García-López and Arizpe, 2010). 
With respect to procedural criteria, Bernstein has found that inclusiveness and participation of different 'relevant audiences' are key procedural requirements for legitimacy granting, especially in cases of strong substantive normative divergence (Bernstein, 2011). Inclusiveness and participation are two of the elements of what Scharpf (1997) labelled as 'input legitimacy' i.e. the procedural requirements of the rule-making process (Bäckstrand, 2006; Biermann and Gupta, 2011). Some authors consider that the multi-stakeholder and deliberative nature of NSMD systems indicates that these systems are well suited to ensure representation and inclusiveness (Bernstein, 2005; Pattberg, 2006). However, the multistakeholder representation and deliberation at the international level does not guarantee inclusion and participation of local actors (Pesqueira and Glasbergen, 2012). To overcome this pitfall, some NSMD sustainability governance systems provide for processes of regional or national interpretation of the international standard. ${ }^{7}$ These national or regional interpretation processes are means of "jumping scales" (Smith, 1984 quoted in Swyngedouw, 2005), i.e. "the transfer of policy domains to sub-national or transnational forms of governance". As a result, "the choreography of actors changes" and "new actors emerge and consolidate their position in the process, while others are excluded or become more marginal" (Swyngedouw, 2005: 2001). Thus, such processes create particular dynamics of legitimacy at the national scale (Bernstein and Cashore, 2004) in which the terms of inclusion and participation, as well as the decisions about effectivenessparticipation trade-offs, are determined by who holds the 'procedural power' and how it is used, i.e. the power to decide sustainability decision-making procedures and the valuation languages determining the bottom-line of the decision-making process (Martinez-Alier, 2002; Muradian et al., 2003; Zografos and Howarth, 2010).

In contexts where sustainability concerns are at the core of socio-environmental conflicts, the values of 'relevant audiences' can be explored through their valuation languages. These are the languages used by actors involved in socio-environmental conflicts to articulate their values, interests and concerns (Martinez-Alier, 2002 and 2009; Avc1 et al., 2010). Moreover, their inclusion and participation in national processes of development of the international standard can be explained in terms of 'procedural power'. Since the concepts of valuation languages and procedural power are used for the analysis, this chapter adds to recent efforts to complement insights from ecological economics and political ecology (Kallis et al., 2013; Zografos and Howarth, 2010). The conceptual framework outlined in this section, showing how the concept of legitimacy is interrelated with the concepts of valuation languages and 'procedural power', is presented in Figure 6.1.

\footnotetext{
${ }^{7}$ The RSPO, the Roundtable on Sustainable Soy and the Forest Stewardship Council are examples of NSMD governance that establish national or regional interpretation processes of the international standard.
} 
Fig. 6.1. Conceptual Framework - Legitimacy, Valuation Languages and Procedural Power

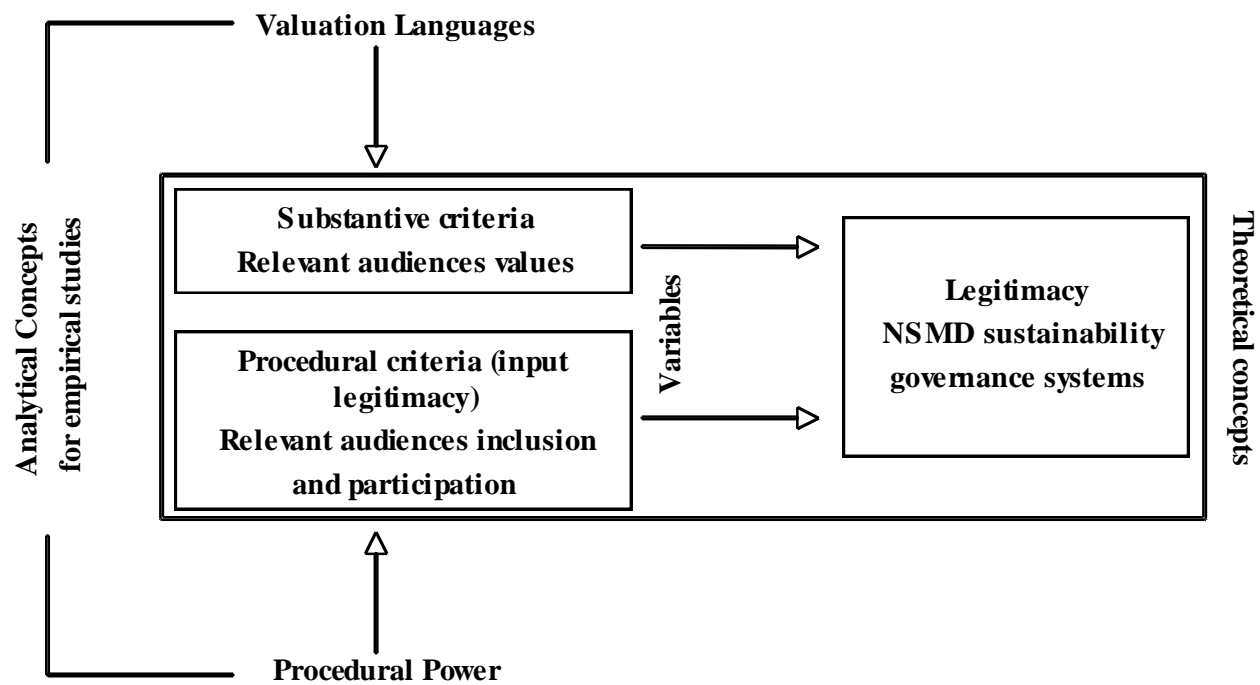

Using this conceptual framework I explore the process of adoption of the Colombian National Interpretation of the RSPO Principles and Criteria focusing on the influence of different actors values and powers on legitimacy granting or contestation of the RSPO in Colombia.

\subsection{Legitimacy contestation of the RSPO in Colombia}

Accelerated expansion of industrial oil palm cultivation in Colombia between 2000 and 2010 has resulted in strong opposition from civil society organizations, and in some places socio-environmental conflicts between the agro-industry and peasants or Afro-Colombian communities have arisen (Table 6.1). ${ }^{8}$ In response to socio-environmental concerns expressed mainly by civil society organization and local actors, the palm oil industry represented by Fedepalma became a member of the RSPO and embarked on the NI process to pave the way for certification of palm oil producers. The conflicts surrounding oil palm expansion in Colombia involve a broad range of local actors who may be potentially affected by, or refuse expansion of oil palm cultivation, and so are 'relevant audiences' of the RSPO in Colombia. It includes actors involved in socio-environmental conflicts such as those identified in Table 6.1, other local actors that may be potentially affected, and the civil society organizations that support different groups of actors.

8 Table 6.1 summarises those cases contained in Table 3.4 (Chapter 3) in which practices of 'accumulation by dispossession' have resulted in socio-environmental conflicts. 
Table 6.1. Socio-environmental conflicts connected with the 2000-2010 expansion of oil palm cultivation in Colombia

\begin{tabular}{|c|c|c|c|c|c|c|}
\hline \multirow[t]{2}{*}{ Case } & \multirow{2}{*}{$\begin{array}{l}\text { Geographical area } \\
\text { (region of the palm } \\
\text { oil geography) }\end{array}$} & \multicolumn{2}{|c|}{ Actors } & \multirow{2}{*}{$\begin{array}{l}\text { Organizations supporting } \\
\text { and advancing claims of } \\
\text { local actors }\end{array}$} & \multirow{2}{*}{$\begin{array}{c}\text { Year of initiation or } \\
\text { exacerbation of the } \\
\text { conflict }\end{array}$} & \multirow[t]{2}{*}{ Source } \\
\hline & & Local actors & \begin{tabular}{|c|} 
Actors in the palm \\
oil commodity chain
\end{tabular} & & & \\
\hline $\begin{array}{l}\text { 1. Las Pavas estate. } \\
\text { Land dispute. Expansion of oil } \\
\text { palm cultivation in the area of } \\
\text { Papayal Island. Eviction of } \\
\text { peasants from areas they use for } \\
\text { their livelihood. Ecological } \\
\text { damage to the marshlands. }\end{array}$ & $\begin{array}{l}\text { Municipality of } E l \\
\text { Peñón-Bolívar } \\
\text { (Central Region) }\end{array}$ & $\begin{array}{l}123 \text { families members } \\
\text { of the peasant } \\
\text { association ASOCAB } \\
\text { (Asociación de } \\
\text { Campesinos de Buenos } \\
\text { Aires) }\end{array}$ & $\begin{array}{l}\text { Consortium of two } \\
\text { large companies of } \\
\text { oil palm cultivation } \\
\text { and palm oil } \\
\text { production }\end{array}$ & $\begin{array}{l}\text { Corporación Desarrollo y } \\
\text { Paz del Magdalena Medio - } \\
\text { CDPMM } \\
\text { (Corporation Development } \\
\text { and Peace of the Magdalena } \\
\text { Medio) }\end{array}$ & 2007 & $\begin{array}{l}\text { Constitutional Court of } \\
\text { Colombia 2011; Soler and } \\
\text { León, 2009; Vargas et al., } \\
\text { 2010. Interview with } \\
\text { coordinator of the land } \\
\text { protection project of the } \\
\text { CPDMM, 2010. }\end{array}$ \\
\hline $\begin{array}{l}\text { 2. Land dispute: plots in the } \\
\text { middle of palm oil plantations in } \\
\text { the municipality of San Alberto } \\
\text { used by peasants for small-scale } \\
\text { subsistence farming. }\end{array}$ & $\begin{array}{l}\text { Municipality of San } \\
\text { Alberto-Cesar } \\
\text { (Central Region) }\end{array}$ & $\begin{array}{l}64 \text { families members } \\
\text { of ASOPRODAGRO } \\
\text { PC (Asociación de } \\
\text { productores } \\
\text { Agropecuarios y } \\
\text { agrícolas del } \\
\text { Corregimiento de } \\
\text { Puerto Carreño) }\end{array}$ & $\begin{array}{l}\text { Large palm oil } \\
\text { cultivation and } \\
\text { production company }\end{array}$ & $\begin{array}{l}\text { CDPMM - land protection } \\
\text { project (legal support for } \\
\text { defence in court). }\end{array}$ & $2003-2004$ & $\begin{array}{l}\text { Juzgado Promiscuo del } \\
\text { Municipio de Aguachica- } \\
\text { Cesar, 2010. (Lower Court). } \\
\text { Interviews fieldwork, } 2011 .\end{array}$ \\
\hline $\begin{array}{l}\text { 3. Afro-Colombian territories in } \\
\text { the Jiguamiandó and Curvaradó } \\
\text { rivers basins. Forced } \\
\text { displacement and ecological } \\
\text { damage in the territories of } \\
\text { Afro-Colombian communities. } \\
\text { Following their eviction and } \\
\text { internal displacement by } \\
\text { paramilitary groups, companies } \\
\text { started oil palm cultivation on } \\
\text { the lands left by displaced } \\
\text { people. At the time of writing } \\
\text { twenty one people were under } \\
\text { criminal judgment linked to } \\
\text { these incidents, including } \\
\text { representatives and shareholders } \\
\text { of palm oil companies. }\end{array}$ & $\begin{array}{l}\text { Municipality of } \\
\text { Carmen del Darién- } \\
\text { Chocó. } \\
\text { (North Region) }\end{array}$ & $\begin{array}{l}\text { Afro-Colombian } \\
\text { communities }\end{array}$ & $\begin{array}{l}\text { Illegal paramilitary } \\
\text { groups and oil palm } \\
\text { cultivation/palm oil } \\
\text { production } \\
\text { companies }\end{array}$ & $\begin{array}{l}\text {-Proceso de Comunidades } \\
\text { Negras (PCN) } \\
\text {-Comisión Intereclesial de } \\
\text { Justicia y Paz } \\
\text { - Defensoría del Pueblo } \\
\text { (Ombudsman Office) }\end{array}$ & 2000 & $\begin{array}{l}\text { Constitutional Court of } \\
\text { Colombia, 2010a; } \\
\text { Defensoría del Pueblo, } \\
\text { 2005; Franco and Restrepo, } \\
\text { 2011; ICHR, 2008; Alfonso } \\
\text { et al., 2011. } \\
\text { Interview National } \\
\text { Ombudsman Office } \\
\text { fieldwork, 2010. }\end{array}$ \\
\hline
\end{tabular}




\begin{tabular}{|c|c|c|c|c|c|c|}
\hline $\begin{array}{l}\text { 4. Afro-Colombian territories of } \\
\text { Alto Mira and Frontera. } \\
\text { Palm oil company illegally } \\
\text { occupied land belonging to the } \\
\text { collective territories of the Afro- } \\
\text { Colombian communities. } \\
\text { Occupation by palm oil } \\
\text { company started in } 1998 \text { but a } \\
\text { legal decision was made in } 2006 \\
\text { declaring the occupation as } \\
\text { illegal and recognizing the Afro- } \\
\text { Colombian communities's right } \\
\text { to the land. }\end{array}$ & $\begin{array}{l}\text { Municipality of } \\
\text { Tumaco-Nariño } \\
\text { (South-west Region) }\end{array}$ & $\begin{array}{l}\text { Afro-Colombian } \\
\text { communities }\end{array}$ & $\begin{array}{l}\text { Palm oil production } \\
\text { and cultivation } \\
\text { company }\end{array}$ & $\begin{array}{l}\text { - Proceso de Comunidades } \\
\text { Negras (PCN) } \\
\text { - Defensoría del Pueblo } \\
\text { (National Ombudsman } \\
\text { Office) }\end{array}$ & $\begin{array}{l}\text { Displacement started in } \\
1996 \text { (around } 100 \\
\text { persons), but it reached } \\
\text { its peak in } 2000 \text { (around } \\
8,500 \text { persons). } \\
\text { Also around year } 2000, \\
\text { six companies started to } \\
\text { plant oil palm in the } \\
\text { area. }\end{array}$ & $\begin{array}{l}\text { Defensoría del Pueblo, } \\
\text { 2010; } \\
\text { Fiscalía General de la } \\
\text { Nación, 2010. } \\
\text { Interview National } \\
\text { Ombudsman Office } \\
\text { fieldwork, 2010. }\end{array}$ \\
\hline $\begin{array}{l}\text { 5. Guapi Abajo palm oil project. } \\
\text { Disputes about the ecological, } \\
\text { economic and social effects of a } \\
\text { project for the cultivation of oil } \\
\text { palm in } 15,000 \text { hectares } \\
\text { belonging to the collective } \\
\text { territory of the Afro-Colombian } \\
\text { community of Guapi Abajo. }\end{array}$ & $\begin{array}{l}\text { Municipality of } \\
\text { Guapi-Cauca } \\
\text { (South-west Region) }\end{array}$ & $\begin{array}{l}\text { Afro-Colombian } \\
\text { communities of } \\
\text { collective territories } \\
\text { other than Guapi } \\
\text { Abajo. }\end{array}$ & $\begin{array}{l}\text { National } \\
\text { government, local } \\
\text { government and the } \\
\text { Afro-Colombian } \\
\text { community of Guapi } \\
\text { Abajo. }\end{array}$ & $\begin{array}{l}\text { - COCOCAUCA (regional } \\
\text { organization grouping } 9 \\
\text { Afro-Colombian } \\
\text { communities from the } \\
\text { Cauca province) } \\
\text { - Proceso de Comunidades } \\
\text { Negras }(\text { PCN) } \\
\text { - Vicariato de Guapi } \\
\end{array}$ & 2007 & $\begin{array}{l}\text { IAvH, 2008; Carvajal, } \\
\text { 2010; Alfonso et al., } 2011\end{array}$ \\
\hline $\begin{array}{l}\text { 6. Bellacruz estate. } \\
\text { Land dispute dating from the } \\
\text { late } 1980 \text { s between a wealthy } \\
\text { family that appropriated public } \\
\text { lands and peasants that } \\
\text { requested titling. Peasants had to } \\
\text { leave the lands due to } \\
\text { displacement through violent } \\
\text { acts. When they returned, they } \\
\text { tried to continue with the legal } \\
\text { procedure for titling. However, } \\
\text { they found that palm oil } \\
\text { companies had occupied the } \\
\text { land with an oil palm plantation. }\end{array}$ & $\begin{array}{l}\text { Municipality of } L a \\
\text { Gloria-Cesar } \\
\text { (Central Region) }\end{array}$ & $\begin{array}{l}64 \text { families members } \\
\text { of the peasant } \\
\text { association ASOCOL } \\
\text { (Asociación } \\
\text { Colombiana Horizonte } \\
\text { de Población } \\
\text { Desplazada) }\end{array}$ & $\begin{array}{l}\text { Business group made } \\
\text { of new foreign } \\
\text { investors and } \\
\text { national oil palm } \\
\text { growers that bought } \\
\text { the land from the } \\
\text { family involved in } \\
\text { the historical dispute. }\end{array}$ & & 2008 & $\begin{array}{l}\text { Verdad Abierta, 2011a, } \\
\text { 2011b and 2013a. }\end{array}$ \\
\hline
\end{tabular}


The NI process was meant to develop the generic RSPO P\&C through a participatory process in accordance with local concerns. However, the RSPO has been strongly contested by local actors. Several civil society actors from both Colombia and elsewhere signed the 'Declaration of Social Organizations and Communities Regarding the Intentions of the First Latin American Meeting of the Roundtable on Sustainable Palm Oil in Cartagena, Colombia'. Organizations that give voice to rural actors involved in socio-environmental conflicts in Colombia were among the signatories, including: i) national Non-Governmental Organization (NGOs) that have supported these rural groups in advancing their claims, such as the Comisión Intereclesial de Justicia y Paz (it has supported actors in Case 3 in Table $6.1)$; ii) grassroots organizations representing local actors, for example the Proceso de Comunidades Negras PCN (represents Afro-Colombian communities including those in Cases 3, 4 and 5 in Table 6.1) and ANUC-UR Asociación Nacional de Usuarios Campesinos Unidad y Reconstrucción (represents peasants such as those involved in Cases 1, 2 and 6 in Table 6.1), and iii) communities involved in socio-environmental conflicts like those in Case 3 in Table 6.1.

The declaration referenced to above was prepared for First Latin American Meeting of the RSPO in Colombia (this meeting took place after the stakeholders meetings carried out for the Colombian NI process were held). The message contained in the declaration can be seen as a clear contestation of legitimacy, as illustrated by the following paragraph:

"We reject initiatives like the Roundtable on Sustainable Palm Oil
(RSPO), which is based on the false premise of establishing criteria for
sustainability and giving a stamp of approval to palm plantations, in
order to sell the product with social and environmental guarantees, thus
seeking to legitimize a harmful business that infringes on the rights of
$\underline{\text { indigenous, Afro-Colombian and peasant communities. At the same time }}$
as it seriously impacts lands and natural heritage through a strategy that
$\underline{\text { seeks to facilitate the marketing of products derived from the oil palm, the }}$
$\underline{\text { RSPO generates only higher dividends, and not solutions to the conflicts }}$
$\underline{\text { that are created. In fact, no certification process can guarantee such }}$
solutions." (Emphasis added).

This legitimacy contestation can be explained by: i) the core values of local actors who are involved in socio-environmental conflicts to resist expansion of industrial oil palm

9 The complete text of declaration in its English version is available at: http://www.wrm.org.uy/subjects/agrofuels/Declaration_Social_Organizations_Communities_Regardi ng_RTSPO.html (accessed January 14, 2013). 
cultivation (Section 6.4); and ii) where the 'procedural power' was held, and by whom, in the NI process and how it influenced inclusion and participation (Section 6.5).

For this study, I collected data on: i) socio-environmental conflicts connected with oil palm cultivation in Colombia and the valuation languages of the actors involved, and ii) data on RSPO and the Colombian National Interpretation of the RSPO P\&C.

Data on socio-environmental conflicts were drawn from: i) a literature review of cases for which socio-environmental effects have been reported in different regions of palm oil cultivation in Colombia; and ii) open-ended interviews, group meetings and direct observation during fieldwork in Colombia. The literature review of cases followed the method of Gerber (2011) in his analysis of conflicts over tree plantations. I only selected cases from public official documents of state institutions and the academic literature, or cases that have been subject to in-depth analysis by several institutions, so that information could be cross-checked. This choice of sources is justified by the difficulties and constraints of cross-checking information about cases documented in single reports published by nongovernmental organizations, industry or media. I complemented the literature review with primary data from open-ended unstructured interviews and group meetings with different actors in one of the regions of palm oil cultivation - Central region - and relevant informants at national level. Interviews, group meetings and direct observation were conducted during two periods of fieldwork in Colombia (see Chapter 2 and Appendix A).

Analysis of the NI process is based on data from interviews with key informants and secondary sources that recall how the process was conducted, and the positions of different actors in respect of oil palm expansion, the RSPO and the NI process. Data were principally collected from two sources: i) open-ended unstructured interviews with key informants conducted during the fieldwork, plus one open-ended interview made abroad with the person representing the only member of the RSPO executive board that visited Colombia to check the NI process - Oxfam Novib, and ii) the documents of the NI process published by Fedepalma and the RSPO, as well as a report by Seebolt and Salinas (2010) that contains the results of an evaluation of the Colombian NI process commissioned by Oxfam Novib.

The analysis reported in Sections 6.4 and 6.5 is based on the conceptual framework explained in Section 6.2 that combines insights from the literature on legitimacy of NSMD governance systems based on critical sociology, with concepts from ecological economics and political ecology. 


\subsection{Actors and values in oil palm socio-environmental conflicts and the legitimacy of the RSPO in Colombia}

There are two types of actors associated with socio-environmental conflicts resulting from the expansion of oil palm cultivation in Colombia, as shown in Table 6.1. The first group is made of actors interested in industrial oil palm cultivation, which follows a monoculture model. For practical reasons, in this chapter I call this group the 'oil palm actors'. The second group is made up of people living in rural areas (rural people), such as peasants and Afro-Colombian communities, who resist integration into palm oil production chains. The valuation languages of these two groups as regards the contested land and the expansion of oil palm cultivation reveal pronounced differences among their core values. This clash of values is at the root of the socio-environmental conflicts.

The concepts of wealth creation, competitiveness, economies of scale, entrepreneurship, market share, and efficiency are repeatedly present in the language of oil palm actors. They also claim to be committed to rural development and social inclusion, and some of them actually have corporate social responsibility programmes. For example, the Colombian palm oil industry 'inclusive businesses' strategy seeks to integrate small-scale farmers in the production chain through contract farming agreements called 'productive alliances' (see Chapter 3). However, the industry engages with this model because of its interest in increasing the scale of production. As Rangel et al., (2009: 21) point out: these alliances are "an innovative paradigm of collective action connected with economies of scale." 10

Thus, the rationale of oil palm actors when they seek access to land for oil palm cultivation corresponds with their business goals and interests. As a consequence, when they refer to land they use the language of exploitation and the language of the market. The factors that they take into account in relation to land access are illustrative: i) how much the land costs, ii) the minimum amount of land needed for the cultivation to be economically feasible, iii) how much land is required to produce enough palm fruit to meet the production capacity of the palm oil extraction plant and ensure economies of scale, and iv) the most efficient strategies to gain access to land in such a way that maximum profitability and competitiveness are achieved. Land is therefore valued in financial cost-benefit terms.

In contrast, rural people involved in the cases given in Table 6.1 consider land as an essential element of the whole environment that constitutes not only the "place" or "space" where they make a living, but also the "space for being" i.e. the habitat where they develop "their being in/with nature" (Escobar, 1998 and 2008). Peasants, indigenous people and

10 The original quote in Spanish is: "un novedoso paradigma de acción colectiva vinculado a economías de escala". 
Afro-Colombians often use the term 'territory' to refer to this space. They attribute a meaning to this concept that encompasses the cultural, ecological and productive dimensions of their lives. In their view, the 'territory' comprises of both ecological and human elements in a way that their livelihood practices and identity are inextricably intertwined with the natural environment they inhabit. ${ }^{11}$ This particular language of 'territory' entails a mode of relating with land that includes its productive function but goes beyond it. It is central to their identity. The land sustains not only the natural environment that indigenous people, Afro-Colombians and peasants inhabit and depend on, but also the relationships, practices and human-nature interactions that identify their specific culture and identity. In the interviews, peasants consistently mentioned that living on, and with the land, as well as their traditional land-based forms of production, are at the core of being peasants. The traditional systems of production may include multiple activities such as low-intensity agriculture of traditional food crops like plantain and fruits, livestock raising, and fishing (Escobar, 2003; fieldwork observations). Therefore, the productive activities and practices that are essential to these actors' identity and culture co-exist with, and depend on, the natural environment in a different way to that of agro-industrial oil palm monoculture. Furthermore, living on the land allows the establishment and reinforcement of kinshipbased social relationships, thereby strengthening identity and culture, and contributing to formation of social capital and solidarity ties (fieldwork observations). Therefore, the language of the 'territory' reflects values that cannot be measured exclusively in monetary terms and does not follow the logic of utilitarian economic cost-benefit decision. Thus, land is valued in terms of livelihoods understood as a source of identity (Avc1 et al., 2010; Bebbington et al., 2008a). The land is not only a means to make a living, but also gives meaning to their worlds and gives them "the capability to be and to act" (Bebbington, 1999: 2022).

Industrial cultivation of oil palm, as revealed by its market language of exploitation, entails a substantial change in the traditional practices and modes of interaction with the land and the environment of the indigenous people, Afro-Colombians and peasants who resist oil palm cultivation. It is incompatible with their values. Unlike traditional production systems, industrial oil palm cultivation takes the form of monoculture plantations of palm from which people not directly involved in palm cultivation, other crops and livestock are excluded. A statement from one interviewee is illustrative of how these rural actors perceive this difference between their traditional practices and oil palm agro-industry: "the palms are as their owners, they cannot live in the same space with something or someone that is different from themselves" (group meeting during fieldwork in 2011, Case 2 Table 6.1).

\footnotetext{
${ }^{11}$ For definitions of 'territory' by indigenous people, peasants and Afro-Colombian communities see http://www.pazdesdelabase.org/index.php?option=com_wrapper\&view=wrapper\&Itemid $=253$

(accessed January 14, 2013)
} 
Furthermore, in contrast to most of the crops that these actors grow in their lands, oil palm fruits are not edible. This is one of their main concerns. As one interviewee expressed, if they leave their lands to oil palm cultivation, they put at risk their food-security, as they cannot eat oil palm fruits (interview during fieldwork in 2011, Case 2 Table 6.1). Moreover, oil palm being a non-native tree, rural people do not know how to grow it and they fear they would become dependent on the farming knowledge of the agro-industry. Finally, the monoculture requires farming practices that are irreconcilable with these actors' tradition of living in and with the land, such as aerial spread of pesticides and the maximum exploitation of the terrain that leaves minimum space for native species and other land uses (group meetings during fieldwork in 2011, Case 2 Table 6.1).

It is because of this particular vision of the 'territory', that the rural people involved in the conflicts detailed in Table 6.1 oppose expansion of industrial oil palm cultivation in the places that constitute the territories of the former, and reject integration into the global or national palm oil chain. They see it as a threat to their traditional farming practices and way of life, while industrial production exploits the resources of the environments that have ensured their livelihoods (group meeting during fieldwork in 2011, Case 2 Table 6.1; Case 1 Table 6.1).

Furthermore, not only does the language of the actors differ in regard to their relation with land, but also the language they use to refer to the impacts of expansion of palm oil cultivation are remarkably different. Oil palm actors consistently resort to quantitative and statistical data to emphasise the potential and actual positive results of increasing oil palm cultivation, in terms of rural development and employment, environmental sustainability, and economic contribution to the national and local economies (palm oil agro-industry interviews and documents). Conversely, rural people involved in socio-environmental conflicts report potential or existing negative impacts of palm oil expansion that they experience as inhabitants of the 'territory'. They recount these impacts from the perspective of their own experiences and traditional knowledge. For example, they tell of the death of fish and livestock after pesticides are spread aerially over the oil palm plantations. They also report the decrease in fish numbers and pollution of the river that passes through both their parcels of land and the oil palm plantation (interviews during fieldwork in 2011, Case 2 Table 6.1). To identify these impacts they draw on the experiences from their daily life and knowledge of the environment they inhabit. However, oil palm actors and technical experts working for them, or for the government, often dismiss the language through which this knowledge is expressed. This difference between languages has translated into power imbalances. Since the government speaks the same language as the oil palm actors, the latter's quantitative discourse has served to justify expansion of the agro-industry with strong governmental support and poor regulatory control. Conversely, the experience-based 
claims of rural people resisting oil palm cultivation have been rejected as isolated and anecdotal cases lacking "hard" evidence.

The valuation languages through which the rural actors who resist expansion of oil palm cultivation articulate their values were reproduced in response to the RSPO, as demonstrated in the following paragraph of the declaration against the RSPO referred to in Section 6.3:

\begin{abstract}
"We advocate: Recognition and respect for the rights of local communities to their lands and their heritage, as well as reparations for the victims of the agro-industrial model of oil palm production in the country.

A halt to the expansion of palm plantations and the processing of raw materials for agro fuels on the lands of local communities, since these fuels are intended to supply unsustainable markets and consumption, $\underline{a t}$ the cost of the sacrifice of our heritage and our lands." (Emphasis added)
\end{abstract}

The call for "a halt to the expansion of palm plantations" is in clear conflict with the goal promoted by the RSPO: "the growth and use of sustainable palm oil through cooperation within the supply chain and open dialogue between its stakeholders" (RSPO, 2007). Implicit in the RSPO's goal is defence of the palm oil market, which entails increasing oil palm cultivation. This is the logical corollary of the market-driven nature of the RSPO. However, expansion of oil palm cultivation is exactly what local actors involved in socioenvironmental conflicts reject on the basis of their valuation of land as an essential part of their 'territories'. This explains why these local actors, and the civil society organizations that support them, expressly denied legitimacy to the RSPO by refusing to accept its appropriateness to solve the issues at the centre of socio-environmental conflicts, as shown in the excerpt of the declaration quoted in Section 6.3.

\title{
6.5. Whose values, whose power in the Colombian National Interpretation of the RSPO Principles and Criteria
}

The RSPO has established a minimum set of rules that must be followed during any national interpretation process in order to be endorsed by the RSPO Executive Board. The process has to be initiated and coordinated by a RSPO member; and to ensure that all RSPO interest categories are included, the process must be carried out by a working group, which should consist of representatives of each of the following categories and at least one member of each interest category should be an RSPO member: i) producers, including small-scale growers, ii) supply chain and investors, iii) environmental interests, iv) social 
interests. Relevant government representatives and technical experts should also be invited to be part of the working group. Moreover, the RSPO system includes two rules to provide the process with a participatory character: i) "the working group must show evidence that it has sought and taken account of input from producers, supply chain and investors, environmental interests and social interests", and ii) there must be public consultation periods for obtaining comments on the national interpretation drafts (RSPO, 2007).

In the case of the Colombian National Interpretation, Fedepalma initiated the process and was part of the working group together with World Wildlife Fund (WWF) Colombia and the Institute Alexander von Humboldt (IAvH). Fedepalma's general mission is to protect the interests of the palm oil producers and oil palm growers, and the role of WWF Colombia in the process was mainly to represent the environmental interests. ${ }^{12}$ The IAvH is an independent institute connected to the Ministry of Environment, Housing and Territorial Development (MAVDT) and acts as its research branch. However, its role in the NI process is considered marginal (personal interviews). Therefore, no member of the leading working group represented the interests of local actors who are, or may be, affected by socioenvironmental impacts of oil palm cultivation. It was mainly Fedepalma and WWF Colombia who decided the structure of the process and the actors who would be convened to participate in the NI process. They also drafted the first version of the NI that was going to be discussed, as well as the versions that followed the compilation of the results from the meetings with experts and stakeholders. They prepared the final version of NI, as well as the supporting document of the process, that were sent for endorsement by the RSPO Executive Board. Thus, 'procedural power' was in the hands of Fedepalma and WWF Colombia. This shaped the terms of inclusion and participation of different actors. This is a typical top-down model where "[i]t is the initiating actors who select the form and function of the process, the stakeholders, and those who will represent them. The final decision often rests with the initiators, and the process is seen as advisory, not binding" (García-López and Arizpe, 2010: 197).

In compliance with RSPO rules aimed at giving the national interpretation processes a participatory character, the working group resorted to two strategies. First, the NI documents were posted on Fedepalma's website for online consultation with the possibility for outsiders to make comments. Second, actors considered by working group as representatives of different categories of stakeholders (environmental, social and productive

\footnotetext{
12 The person representing WWF Colombia in the NI working group moved to work for Fedepalma after the NI process was endorsed, raising doubts about the independent and genuine representation of environmental interests in the NI process. This change of office had already taken place by the time of my fieldwork and WWF Colombia's interviewee who replaced this person appeared to be not very familiar with the NI process. This explains why the views of WWF Colombia are underrepresented in this chapter.
} 
sectors) were requested to participate in workshops in the capital - Bogotá - and in the four regions of palm oil production (see Fig. 6.2). Research and education institutions, international organizations, certification agencies and the media were also invited. The process was planned to be completed in about 10 months, starting in July 2008. The initial plan was to submit the NI for RSPO endorsement in May 2009 (Seebolt and Salinas, 2010). The plan was delayed due to intervention of Oxfam Novib, using its power as a member of the RSPO Executive Board, to commission an evaluation of the NI process (see Fig. 6.2).

Some findings of the evaluation include: i) neither representatives of Afro-Colombian, indigenous people and peasant grassroots, nor food security organizations were present in any of the meetings, ii) participation in terms of numbers by these actors was low and iii) representatives of social and environmental organizations considered that the methodology used was not appropriate for effective participation.

Fig. 6.2. Timeframe of the Colombian RSPO P\&C NI process

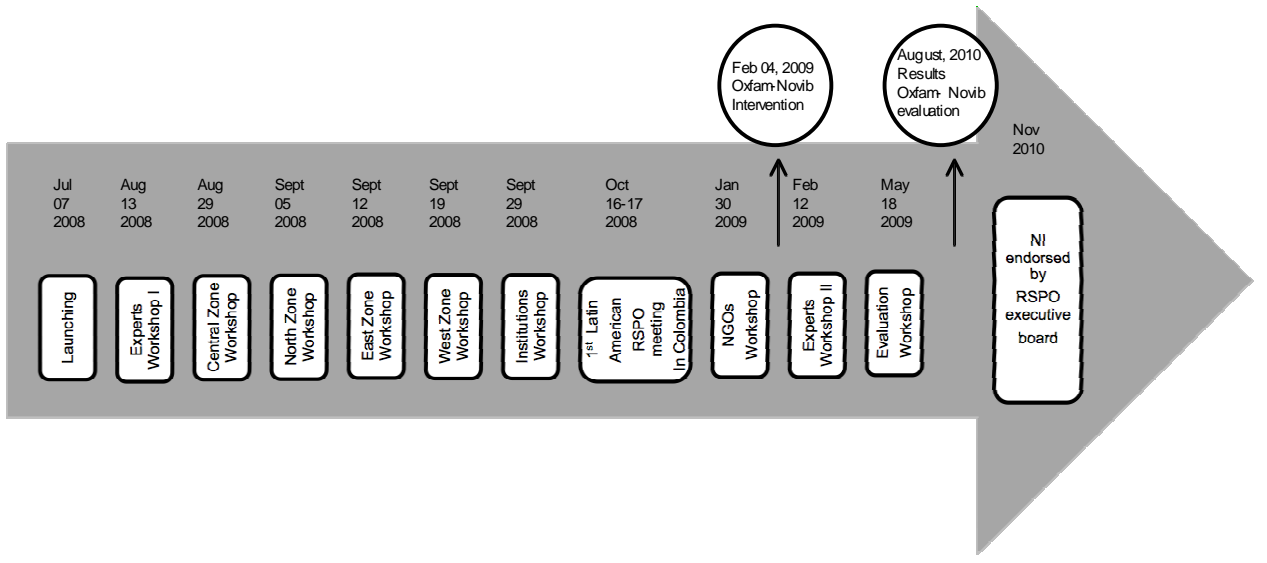

Source: Fedepalma, 2010b; Seebolt and Salinas, 2010.

Two characteristics of the NI process show that in spite of its apparent participatory character, 'procedural power' in the hands of Fedepalma undermined the effective participation by local actors affected by, or resisting against, expansion of oil palm cultivation.

First, attendance at, and representation of, these actors in the regional workshops was limited, even though these meetings were held in places that could be considered better 
suited for their effective participation. Furthermore, participation of local actors versus representatives of the productive sector, was unbalanced. Attendees were about $50 \%$ of invitees (Fig. 6.3). Of those who attended, more than $50 \%$ were representatives of the productive sector in the four regional workshops. Conversely, local actor representatives were less than $10 \%$ of attendees in three workshops (see Fig. 6.4). Although the proportion increased to $23 \%$ in the case of the Central Region workshop, it is important to clarify that this $23 \%$ includes representatives of small-scale growers of oil palm (Fedepalma, 2010b: 27). This means that the percentage of participants independent of the productive sector was less than $23 \%$.

Fig. 6.3. Comparison of invitees and attendees to regional workshops held for the Colombian RSPO P\&C NI

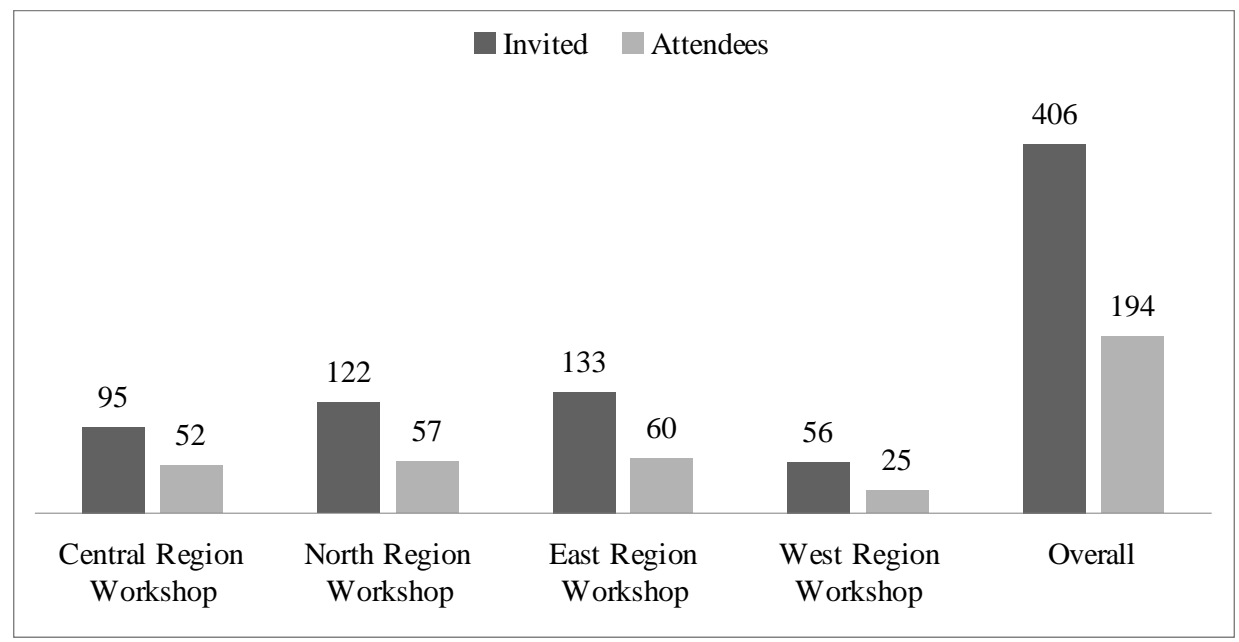

Source: based on numbers presented by Fedepalma to the RSPO in its final report of the NI process (Fedepalma, 2010b). However, I would like to clarify that the number of people invited to the regional workshops reported by Fedepalma (406 persons) differs from that reported in the evaluation commissioned by Oxfam Novib (1350 persons) (Seebolt and Salinas, 2010). 
Fig. 6.4. Participation per sector of the attendees to the regional workshops held for the Colombian RSPO P\&C NI.

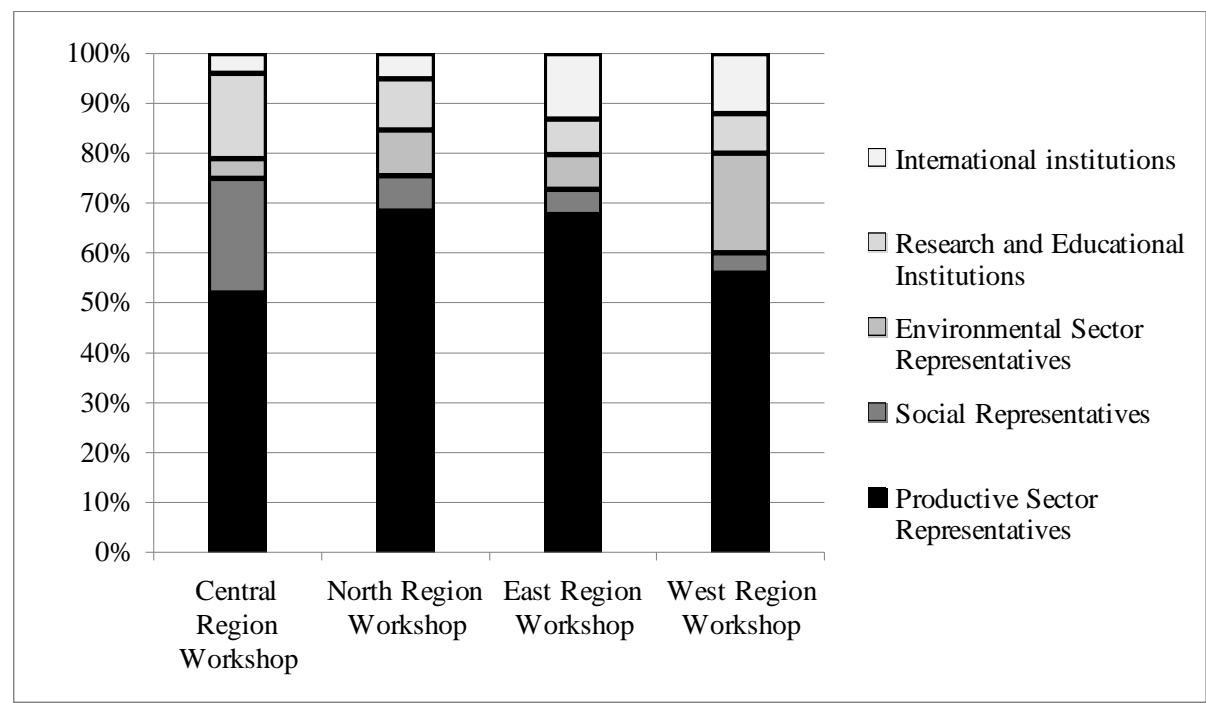

Source: Fedepalma, 2010b.

The relatively small percentage of social representatives that participated in the regional workshops (Fig. 6.4) may be explained by the influence of three factors: i) actors who could bring to the table the issues at the core of socio-environmental conflicts - representatives of Afro-Colombians, indigenous people and peasants - were not invited. Thus, 'procedural power' was used to operate a "selective inclusion of stakeholders" (García-López and Arizpe, 2010: 197) that facilitated exclusion of contentious issues from the discussions. In that way the NI process could move smoothly in accordance with the planned schedule. ii) The regional workshops were planned by the organizers to follow a very tight schedule, i.e. four to be held within 22 days (see Fig. 6.2). As a consequence they were organized as oneday meetings held in one town for each palm oil producer region. Under these conditions, attendance and effective participation of representatives of rural people was highly unlikely. This is because each region is vast (see Table 6.2), and locations of the workshops meant it was difficult - if not impossible - and/or expensive for rural people living in remote areas who rely on public transport to attend. In this way the 'procedural power' in the hands of Fedepalma worked against effective participation of local actors, while Fedepalma responded to the interests of the business actors to conduct the process as quickly and efficiently as possible to ensure market access through certification. iii) The NI process was led by the organization representing the interests of their adversaries - Fedepalma - which may have created a feeling of distrust in the NI process on the part of local actors resisting 
oil palm cultivation, thereby influencing decisions of voluntary exclusion from the process. This lack of trust is rooted in the ecological and social threats that industrial oil palm cultivation, embodied by Fedepalma and its members, is seen to pose to their 'territories' and livelihoods in the eyes of local actors. This echoes the argument of Pesqueira and Glasbergen (2012: 7) that "scandals involving RSPO members about abusive corporate practices in land disputes in Colombia, Indonesia, and Malaysia diminish the capacity of the RSPO to provide meaningful mechanisms for accountability and social participation". Similar findings have been reported in connection with the Roundtable on Responsible Soy. Peasants and civil society organizations opted out of consultations on standard-setting for the Roundtable on Responsible Soy as the expansion of soy cultivation is seen by these actors as a threat to local communities' livelihoods (Elgert, 2012; García-López and Arizpe, 2010).

Table 6.2. Oil palm producer towns and hectares planted per region.

\begin{tabular}{|l|l|l|l|l|}
\hline & Central Region & North Region & East Region & West Region \\
\hline $\begin{array}{l}\text { Producer towns in the } \\
\text { regions in 2007 }\end{array}$ & 28 & 37 & 29 & 2 \\
\hline $\begin{array}{l}\text { Hectares planted with } \\
\text { oil palm in the region in } \\
2007\end{array}$ & 77,594 & 97,881 & 106,317 & 34,610 \\
\hline
\end{tabular}

Source: Fedepalma, 2008

Second, the perception of some representatives of the social and environmental sectors who attended NI workshops was that the process was not really inclusive and the methodology was not appropriate to enable true participation, in the sense that participants were able to influence outcomes. The evaluation report commissioned by Oxfam Novib sums up the views of these organizations in this regard:

"In their view, these events were nothing more than formal spaces, which
lacked adequate mechanisms for participation and representation and
offered no possibility for addressing or further analysing the problems
identified or the scope of the RSPO as an instrument to help seek
solutions or to improve the palm industry." (Seebolt and Salinas, 2010:
43).

These perceptions, like the scarce attendance and participation of social representatives in the regional workshop, are grounded in the choices made by the working group with respect to aspects of the design of the process such as the schedule, and the number and duration of the workshops. 
In summary, the design of the NI process was neither appropriate to enable inclusion of the people living in rural areas that may be affected by or resist oil palm cultivation, nor was it suitable to facilitate meaningful participation and deliberation of social representatives during the meetings. A design aimed at ensuring inclusion and participation would have required more meetings per region and providing the resources (either transport of financial assistance) to enable attendance by those people living in remote areas far from the meeting place. This requires more consultation with all actors about their needs for effective participation. Moreover, more than one day per workshop would have been necessary to ensure deliberation, which requires building consensus (Zografos and Howarth, 2010). However, such a design would have entailed a longer NI process and more financial resources, which would have played against the efficiency interests of the business actors represented by Fedepalma. Therefore, by virtue of having the 'procedural power', Fedepalma solved the trade-off between efficiency and participation by constructing processes that favoured the interests of its constituencies. As a key interviewee who closely followed the NI process pointed out, Fedepalma did just the minimum necessary to comply with the requirements of the RSPO for endorsement of the NI process. Indeed, Fedepalma considered that the national interpretation was not meant to be a consultation process (interview with Fedepalma official). Furthermore, in the words of Fedepalma in its response to Oxfam Novib's evaluation report "the national interpretation process consisted of an academic exercise" (Fedepalma, 2010b: 44).

The input legitimacy outcomes of the NI process in Colombia thus resonate with Swyngedouw's argument that the inclusive and participatory promises of the governance system are illusory "under conditions in which the democratic character of the political sphere is increasingly eroded by the encroaching imposition of market forces that set the 'rules of the game"' (Swyngedouw, 2005: 1993).

The weaknesses of the NI process in terms of input legitimacy requirements described in this section probably reinforced legitimacy contestation of the RSPO by local actors resisting oil palm cultivation. This is demonstrated by the fact that the declaration against the RSPO was released after the regional and national workshops took place, on the occasion of the First Latin American Meeting of the RSPO (see Fig. 6.2).

\subsection{Conclusions}

This chapter focuses on the legitimacy of NSMD sustainability governance systems. It aims to investigate how different values and powers at play in national processes of developing sustainability criteria influence legitimacy granting or contestation by local actors involved in socio-environmental conflicts. To do so, I analysed the case of the process of adopteion 
of the Colombian National Interpretation of the RSPO P\&C using an approach that combines a concept of legitimacy based on critical sociology with concepts from political ecology and ecological economics. This study reveals how national legitimacy dynamics of acceptance or contestation of NSMD sustainability governance systems are shaped by both: i) the core values of the relevant local audiences as regards the resources disputed through socio-environmental conflicts and ii) who holds 'procedural power' and how it is used to ensure or hinder inclusion and participation of 'relevant audiences' in national processes of developing sustainability criteria. Thus, this chapter also explores the appropriateness of the notions of valuation languages and 'procedural power' that come from ecological economics and political ecology to investigate legitimacy dynamics of NSMD sustainability governance systems. These notions enable an analysis of how legitimacy granting or contestation by 'relevant audiences' is shaped by values and power at play in standardsetting processes that involve plurality of actors holding conflicting values and asymmetrical powers, which would not be shown by other approaches. The study of legitimacy of non-state global governance mechanisms, such as NSMD schemes, has been traditionally approached using perspectives that come from the disciplines of law, political philosophy, political science and sociology (Bernstein, 2005; Schouten and Glasbergen, 2011). Therefore, the way in which I operationalise the conceptual framework based on Bernstein's notion of legitimacy using concepts that come from research at the intersection between political ecology and ecological economics constitutes an innovation in the study of the legitimacy of NSMD sustainability governance mechanisms.

In the case of Colombia I found that the process of adoption of the national interpretation of the RSPO P\&C revealed power asymmetries among stakeholders and clashes between their different values. This resulted in strong contestation of the legitimacy of the RSPO from the part of civil society organizations and local actors who resisted expansion of oil palm cultivation. Such contestation was coupled with deficiencies in input legitimacy (lack of inclusion and participation) rooted in a use of 'procedural power' by Fedepalma that: i) aligned the process with the cost-benefit market-driven values of its constituencies, and subtly overlooked values and interests of rural people self-excluded from the commodity chain.

Although legitimacy of the RSPO has been strongly contested by local actors, in the short run this contestation has not transformed the market logic underlying the certification mechanism. For example, criticisms regarding the NI contained in the evaluation of the Colombian NI process commissioned by Oxfam Novib were partially and superficially addressed in the National Interpretation document that was presented to, and endorsed by the RSPO Executive Board. Moreover, the only palm oil producing company that has obtained certification in Colombia according to data available until the end of 2013 - C.I 
Tequendama (an affiliate of DAABON business group) - had been involved in a socioenvironmental conflict (Case 1 in Table 6.1). This company was able to obtain RSPO certification in spite of its previous involvement in a land conflict because it sold its shares to its business partner in the palm oil project connected with the conflict (see Case 1 in Chapter 5). Thus, the RSPO certification mechanism did not contribute to addressing local actors' concerns at the core of the conflict. This demonstrates that in design and implementation of the RSPO Principles and Criteria, market interests of business actors prevail over a genuine desire to address socio-environmental issues.

However, local actors have used the market logic of business actors in the palm oil commodity chain for advancing their claims. For example, in the same case of conflict referred to in the previous paragraph (Case 1 in Table 6.1), the local actors used strategies of advocacy out of the RSPO system that affected the businesses and market access of C.I Tequendama. Visibility of the dispute achieved through the advocacy strategy affected the palm oil company's reputation to the point that one of its most important international costumers commissioned an independent report about the case and, on the basis of the findings, terminated the supply contract (see Case 1 in Chapter 5).

From the analysis of NI process in Colombia it is possible to draw some conclusions about how power asymmetries among local actors and differences in values deployed in national standard-setting processes influence legitimacy contestation of NSMD sustainability governance systems at the national scale.

Firstly, when the sustainability concerns that NSMD systems aim to address are at the centre of socio-environmental conflicts involving different actors with plural and conflicting values at the local level, all the actors involved in these conflicts are 'relevant audiences' of the governance system. The actors in conflict are on the one side often actors within the commodity chain; while on the other side, there are actors who have opted for self-exclusion from the commodity chain on the basis of values that oppose a market-driven logic. Thus, legitimacy of NSMD systems not only rests on business actors but also on local actors affected by, or resisting against the effects of the industries that NSMD systems aim to govern.

Secondly, legitimacy granting by local actors opposing the industries governed by a NSMD system depends on: i) their perception about the NSMD system's ability to deal with the issues at the core of their claims, which is shaped by correspondence between the local actors' core values and values that the governance system represents and promotes; and ii) their effective participation and inclusion in processes of standard-setting creation and implementation at national and local levels, i.e. compliance with requirements of input legitimacy. 
Thirdly, legitimacy granting by local actors is difficult to achieve if their core values conflict with those of the NSMD governance system. The case of the RSPO in Colombia shows that this occurs when the goals of the NSMD system reflect a choice for accommodating values mainly of interest to the industry due to its market-driven nature. Similar findings from the Roundtable on Responsible Soy standard-setting process confirm this conclusion (Elgert, 2012; García-López and Arizpe, 2010).

Fourthly, input legitimacy can be gained if processes of national interpretation and implementation of the international sustainability criteria are designed in accordance with reality on the ground, i.e. the existence of socio-environmental conflicts. To do so, NI processes should incorporate adequate strategies and methods to facilitate attendance and effective participation of all 'relevant audiences'. This should also include those who opted for self-exclusion from the commodity chain, and who can be affected by the potential socio-environmental impacts of the industries governed by NSMD systems. The marketdriven logic that underlies NSMD governance systems may lead to processes in which the 'procedural power' is used to privilege values and interests of powerful business actors at the expense of local actors affected by, or resisting the effects of the industries governed by NSMD systems. In such a case, legitimacy contestation by those local actors is likely to occur.

Thus, I posit that in such contexts, where clashing values and asymmetries in power that unfold in socio-environmental conflicts are reproduced within the governance system, building trust among the 'relevant audiences' is key to achieving legitimacy by all actors. Trust building requires processes with strong adherence to input legitimacy requirements. Those processes can take long time, entailing a trade-off between participation and efficient decision-making that business actors may not be willing to bear.

Because input legitimacy requirements of inclusion and participation were weakly implemented in the case of the Colombian RSPO P\&C national interpretation process, the analysis contained in this Chapter leaves an important question unanswered: can local level opposition to NSMD systems on the basis of its market-based nature be overcome through a strong and effective inclusion of all 'relevant audiences' into the decision-making process? Further empirical research about other national interpretation processes of international sustainability standards is required to shed light on this subject. 


\section{Chapter 7 \\ Conclusions}

\subsection{Introduction}

The accelerated expansion of commodity frontiers at the expense of environments that sustain the lives of local populations is unfolding in a growing number of socioenvironmental conflicts at the global scale. However, local geographies and domestic social, political and economic processes shape the country-specific trajectories of commodity frontiers expansion and resistance.

In this dissertation, I set out to analyse how the expansion of commodity frontiers is manifested in country-specific trajectories of inequitable resource access. I did so through a case study research on the expansion of the palm oil frontier in Colombia between the years 2000 and 2010 looking at the resource access struggles and resistance connected with such expansion.

The research was approached from the perspective of political ecology using the 'extended case method' (Burawoy, 2009). I also used concepts and insights from other disciplinary fields to enrich the analytical potential of political ecology. In particular, concepts from ecological economics, political economy, peasant studies and critical sociology, as well as theories of environmental justice and human rights.

Section 7.2 of this chapter presents the answers to the research questions set out in Chapter 1. Section 7.3 summarises the contribution of this study to knowledge and practice, and Section 7.4 outlines areas for future research.

\subsection{Conclusions from the empirical chapters}

The empirical chapters of this thesis (Chapters 3, 4, 5 and 6) address the four research subquestions on the basis of empirical evidence from the 2000-2010 expansion of the palm oil frontier in Colombia.

In the following sub-sections (7.2.1 to 7.2.4) I present the conclusions drawn from the empirical chapters for each of the research sub-questions.

In sub-section 7.2.5, I synthesise these conclusions to answer the overarching research question of this dissertation. 
7.2.1. Interactions between global expansion of commodity frontiers, and country-specific trajectories of expansion and resource access control

It is possible to draw some conclusions from the analysis presented in Chapter 3 about how the global expansion of commodity frontiers interacts with national geographies and socioeconomic and political processes to produce country-specific trajectories of expansion and resource access control (Research sub-question 1)

Firstly, the country-specific trajectories of expansion of the palm oil frontier in Colombia demonstrate that commodity booms at a global scale (in terms of accelerated increase in demand and production), and the forms of expansion of commodity frontiers at the national and local scales, are mediated by complex interrelations between national geographies and social, economic and political factors and their historical roots. Therefore, generalised explanations about the causes, effects and forms of expansion of a commodity frontier, based on overall observations at the global level, or, on single country case studies, may result in misleading conclusions with regard to the global dynamics of expansion and expansion in other producing countries. A better understanding of the dynamics of expansion of commodities frontiers requires locally-specific research at the country/local levels, as well as comparative analysis across and between countries and localities.

Secondly, the case study findings support Hall's emphasis on the relevance of the crop features to understand trajectories of expansion in the case of 'crop booms' (Hall, 2011). The Colombian case shows how the 'flex crop' nature of palm oil makes it possible for palm oil producers to align the trajectories of expansion in the 'space-of-flows' with new market opportunities that are more profitable. This supports the conclusion by Borras et al. (2012) that the accelerated expansion of 'flex crops' during the current phase of capitalism is logical, since these crops' versatility allows continuous capital accumulation in a context of multiple converging crises (Borras et al., 2012: 851).

Thirdly, although global expansion of commodity frontiers often entails 'accumulation by dispossession' (Harvey, 2003, Muradian et al., 2012), the case of Colombia demonstrates that it also proceeds through practices of 'assimilation', i.e. an incorporation of the local population into modern processes of development that deny differences rooted in their identity and culture in an attempt to realise a measure of equity (Escobar 2006a and 2006b). Moreover, the analysis carried out in Chapter 3 corroborates Harvey's observation that "accumulation by dispossession can occur in a variety of ways and there is much that is both contingent and haphazard about its modus operandi" (Harvey, 2003: 149). The study of the case of Colombia shows how such ways and modus operandi are shaped by social, economic and political processes specific to the territories of extraction resulting in country- 
specific forms of: 'accumulation by dispossession'; 'assimilation'; and, resistance and conflict.

Finally, in spite of the specificity of the trajectories of the expansion of a commodity frontier in each producing country, those trajectories can be placed in the broader global context, as they correspond with general process associated with capitalist expansion at the global scale. For example, the specific trajectories of land control practices associated with the expansion of the palm oil frontier in Colombia are immersed in a global dynamic of resource extraction in which a "series of changing contexts, emergent processes and forces, and contestations [are] producing new conditions and facilitating shifts in both de jure and de facto land control" (Peluso and Lund, 2011: 669).

7.2.2. Governmental support to extractive industries and power relations shaping access to resources

It is possible to draw some conclusions from the analysis of the Colombian case presented in Chapter 4 about how governmental incentives to support extraction activities mediate power asymmetries among actors in access to resources (Research sub-question 2).

Firstly, the influence of policies on who gains access to resources, and how, is defined, not only by the adoption and implementation of tenure regimes that confer property or user rights, but also by policies, laws and governmental measures aimed at promoting economic activities based on the extraction of resources.

Governmental support in the form of incentives and policies to promote extractive activities may translate into relational and structural mechanisms of access that operate in parallel to rights-based and illegal means of access. Such relational and structural mechanisms constitute the strands of the 'bundle of powers' that enable access to the resources on which the expansion of extraction frontiers is based. Actors interested in capital accumulation from extractive activities frequently rely on access to authority in the form of a 'selective access to the state' to benefit from governmental support. They use this relational mechanism to influence the adoption and implementation of policies and measures that work as structural mechanisms of access, such as capital, knowledge, technology and access to markets. These structural mechanisms enable them to gain and control access to resources for the expansion of extraction frontiers. Thus, governmental support to extractive activities and the forms of access to and control over resources it represents are part of the "political economies of power and accumulation" underlying socio-environmental conflicts (Peluso, 2009: 40). 
Secondly, the relational and structural mechanisms at work through governmental incentives supporting extractive activities operate, not only alongside rights-based mechanisms, but also in spite of them. Structural mechanisms of access may operate through governmental support to extractive activities that allow benefiting from resources even without controlling access through tenure rights. This is demonstrated in the case of palm oil producers that benefit from land by controlling oil palm plantations of 'productive alliances' that were beneficiaries of governmental support in Colombia. Moreover, this type of governmental support entails opportunities for capital accumulation and resource control so attractive that interested actors may use both legal and illegal manoeuvres to get around resource tenure regimes in order to participate in the government-sponsored extractive activities.

Thirdly, the governmental support that privileges specific modes of production and extraction is a manifestation of 'state simplifications' repeatedly inscribed in a historical pursuit of economic and rural development guided by a 'high modernist ideology'. ${ }^{1}$ State simplifications typically fail to "represent the actual activity of the society they depict". Moreover "they enable much of the reality they depict to be remade". By doing so, "they make possible quite discriminating interventions" (Scott, 1998: 3).

Thus, models of economic and rural development that privilege extractive activities, such as capitalist agriculture, neglect the plurality of relations that local people establish with the territories they inhabit and the resulting complex and varied livelihoods. Instead these models favour access to resources of those aligned with the guiding "high modernist ideology".

7.2.3. Justice dimensions involved in the expansion of commodity frontiers and the emancipatory potential of human rights politics

The cases analysed in Chapter 5 lead to the following conclusions about how the dimensions of justice are threatened in practice and defended through the politics of human rights in cases of local resistance connected with the expansion of commodity frontiers (Research sub-question 3).

Firstly, contestation and conflict are signs of, and responses to, the injustices enmeshed in the threats that frontier expansion poses to local people's livelihoods (Martinez-Alier, 2013). The cases analysed show that justice is affected in its four dimensions: distribution,

\footnotetext{
${ }^{1}$ Scott defines 'high modernist ideology' as "a strong version of the self-confidence about scientific and technical progress, the expansion of production, the growing satisfaction of human needs, the mastery of nature (including human nature), and, above all, the rational design of social order commensurate with the scientific understanding of natural laws" (Scott, 1998: 4).
} 
recognition, capabilities and participation (Schlosberg, 2007). However, the ways in which the threats to livelihoods affect different dimensions of justice are case-specific. They depend on how different dimensions of livelihoods - material, meaning and capabilities (Bebbington 1999 and 2004) - are constructed and valued in each specific case.

Secondly, the threats to livelihoods and the resulting injustices derive from two types of practices through which resource control for the expansion of the frontiers takes place, i.e. 'accumulation by dispossession' and 'assimilation'. 'Accumulation by dispossession' affects livelihoods across their multiple dimensions. 'Assimilation' breaks the complex articulation between such dimensions by denying and erasing the cultural differences that underlie different human groups' relationship with their environments and the natural resources that they depend upon for their livelihoods.

Thirdly, the capacity of resistance to overcome the grievances caused by the expansion of commodity frontiers depends on the mechanisms used. Although local populations regularly use different mechanism in parallel, the analysis in Chapter 5 shows that the human rights framework is one of the most powerful instruments of resistance. It allows the articulation of plural dimensions of justice in defence of livelihoods. However, the emancipatory potential of human rights politics depends on how the human rights framework is applied and constructed. Case 1 in Chapter 5 demonstrates that human rights politics produces emancipatory outcomes when the application and interpretation of the normative framework reflect the local meanings of marginalised and silenced groups. This way of applying and interpreting human rights corresponds with Santos's 'multicultural conception of human rights' (Santos, 2002 and 2007).

The analysis in Chapter 5 confirms the conclusion of existing political ecology research that the support of third parties is a factor that enhances the emancipatory potential of resistance. In the cases analysed, third parties, such as grassroots organizations, national and international NGOs, and state or international entities in charge of ensuring rights protection (such as the Office of the Ombudsman and the local and national courts), have been instrumental in:

i) enabling local people who reject oil palm cultivation to maintain access to their lands without being forced to participate in oil palm cultivation; or

ii) making available models of incorporation in commodity chains that are more respectful of culture and identity, and enable independency, self-management and capacity building. 
7.2.4. Legitimacy contestation of non-state market-driven (NSMD) sustainability governance systems at the national scale

From Chapter 6 it is possible to formulate the following conclusions about how power asymmetries among local actors and differences in values deployed in national standardsetting processes influence legitimacy contestation of NSMD sustainability governance systems at the national scale (Research sub-question 4).

Firstly, when the sustainability concerns that NSMD systems aim to address are at the centre of socio-environmental conflicts involving different actors with plural and conflicting values at the local level, all the actors involved in these conflicts are 'relevant audiences' or stakeholders of the system. The actors in conflict are, on the one side, often actors within the commodity chain; while, on the other side, there are actors who have opted for self-exclusion from the commodity chain on the basis of values that oppose a market-driven logic. Thus, legitimacy of NSMD systems rests, not only on business actors, but also on local actors affected by, or resisting the effects of the industries that NSMD systems aim to govern.

Secondly, legitimacy granting by local actors opposing the industries governed by the NSMD system depends on:

i) Their perception about the NSMD system's ability to deal with the issues at the core of their claims; and

ii) Their effective participation and inclusion in processes of standard-setting creation and implementation at national and local levels, i.e. compliance with requirements of input legitimacy.

Thirdly, legitimacy granting by local actors is difficult to achieve if their core values conflict with those of the NSMD governance system. The case of the Roundtable on Sustainable Palm Oil (RSPO) in Colombia shows that this occurs when the goals of the NSMD system reflect a choice for accommodating values mainly of interest to the industry due to its market-driven nature.

Fourthly, input or procedural legitimacy can be gained if processes of national interpretation and implementation of international sustainability criteria are designed in accordance with the reality on the ground, i.e. the existence of socio-environmental conflicts. To do so, national interpretation processes should incorporate adequate strategies and methods to facilitate attendance and effective participation of all 'relevant audiences'. This should include also those who opted for self-exclusion from the commodity chain, and who can be affected by the potential socio-environmental impacts of the industries 
governed by NSMD systems. The market-driven logic that underlies NSMD governance systems may lead to processes in which procedural power is used to privilege the values and the interests of powerful business actors at the expense of local actors affected by, or resisting, the effects of the industries governed by NSMD systems. In such a case, legitimacy contestation by those local actors is likely to occur.

Finally, building trust among the 'relevant audiences' is crucial to achieving legitimacy in contexts in which clashing values and asymmetries in power that unfold in socioenvironmental conflicts are reproduced within the governance system. Trust building requires processes with strong adherence to input legitimacy requirements. Those processes can take a long time and entail a trade-off between participation and efficient decisionmaking that business actors may not be willing to bear.

7.2.5. How is the expansion of commodity frontiers manifested in country-specific trajectories of inequitable resource access?

On the basis of the conclusions drawn from the empirical chapters it is possible to answer the overarching research question of this thesis: how is the expansion of commodity frontiers manifested in country-specific trajectories of inequitable resource access?

The political ecology scholarship has demonstrated already that resource control practices for commodity frontiers expansion frequently take the form of 'accumulation by dispossession' (Harvey, 2003; Muradian et al., 2012). The research of this thesis shows that:

i) Resource control practices also take the form of 'assimilation',

ii) Both 'accumulation by dispossession' and 'assimilation' may be manifested in multiple and varied practices at the country and local levels that produce inequitable access to resources.

The analysis of a number of cases in Colombia shows six types of country-specific practices of 'accumulation by dispossession' used to gain control over land for the expansion of the palm oil frontier, while 'assimilation' was embodied in some of the contract farming arrangements called 'productive alliances'. Actors interested in the expansion of the palm oil frontier gained control over access to land through these practices, while local populations lost, or risked to lose, control over the resources that sustain their livelihoods or accepted 'assimilation' practices at odds with their identity and 'lifeworlds' in order to maintain their access. 
Expansion of a commodity frontier at the national level and the multiple and varied forms that resource control practices of 'accumulation by dispossession' and 'assimilation' take at the local level are shaped by country-specific socio-economic and political processes and national geographies, as well as the material requirements and characteristics of the commodity. These factors define the physical spaces where expansion takes place and how control over access to resources is gained, lost or maintained by different actors in such spaces.

In the case of Colombia the expansion of oil palm oil cultivation between 2000 and 2010 was influenced strongly by an increasing national production of palm oil to be processed into biodiesel for the national market. This increasing production was driven by governmental policies that promoted national biofuel production and consumption and supported palm oil production as a feedstock. Governmental support to the palm oil agroindustry, peasant marginalization, and the socio-political processes connected with the armed conflict shaped the country-specific 'accumulation by dispossession' and 'assimilation' practices used to control land for the expansion of oil palm cultivation in Colombia.

The case of the 2000-2010 expansion of the palm oil frontier in Colombia shows that governmental support to the extractive activities is a very relevant factor mediating actors' power asymmetries in access to resources in commodity frontiers. Such support results in inequitable outcomes when it translates into structural and relational mechanisms of access that facilitate 'accumulation by dispossession' and 'assimilation' practices. However, governmental support to extractive activities varies from country to country because:

i) each country may adopt a different set of incentives and,

ii) the webs of relations that influence who benefits of incentives and how is also context-specific.

As a consequence, the resulting power asymmetries in access to resources also vary from one country to the other and also within countries.

The empirical chapters also show that the inequitable access to resources that result from country-specific manifestations of 'accumulation by dispossession' and 'assimilation' are expressed in threats to different dimensions of the local populations' livelihoods. These threats represent grievances affecting the distribution, recognition, capabilities and participation dimensions of justice. The responses to those threats and grievances by local populations are context-specific. When there is resistance several context- and case-specific factors determine the emancipatory potential of resistance. 
The empirical study of this thesis shows that support from third parties (e.g., NGOs; grassroots organizations; Ombudsman Offices; courts) and the type of mechanisms of resistance used are key factors determining emancipatory outcomes. Case 1 in Chapter 5 demonstrates that human rights politics is a powerful instrument of resistance when the human rights normative framework is applied and interpreted in accordance with a local populations' constellation of meanings.

NSMD sustainable governance mechanisms - such as voluntary certification schemes - are becoming commonly adopted at the national level to address the socio-environmental concerns underlying resistance against the expansion of commodity frontiers. However, the case of the national interpretation of the principles and criteria of the RSPO demonstrates that resistance present in socio-environmental conflicts can reproduce as legitimacy contestation of NSMD sustainable governance mechanisms at the national level.

The case of the RSPO in Colombia also demonstrates that legitimacy contestation occurs when the decision-making process reproduces local and national power asymmetries and overlooks the values of the local populations. This explains why local actors that dispute the expansion of commodity frontiers resort to different strategies outside of NSMD governance systems to articulate their resistance.

\subsection{Contributions to knowledge and practice}

True to the principles of both the reflexive model of science and 'the epistemologies of the South' that underpin this research (see Chapter 2), this thesis contributes to the development and reconstruction of existing knowledge and brings into practice 'the sociology of absences' and 'the sociology of emergences'.

\subsubsection{Contributions to knowledge}

The political ecology scholarship has contributed to a better understanding of the conflicts and resistance that emerge in connection with the expansion of commodity frontiers by:

i) Analysing the interplay between ecological, socio-economic and political processes shaping control over access to resources and the distribution of environmental 'goods' and 'bads', and

ii) Paying special attention to both power relations and the different values and meanings that determine the human-nature interactions of differentiated actors involved in conflict and resistance. 
Political ecology has contributed also to a better understanding of the social mobilisations and resistance through the analysis of:

i) The organisation, strategies and instruments used by the resisting actors, and

ii) The conditions that facilitate or constrain the emergence of resistance and social mobilisation.

Thus, political ecology has offered most of the conceptual and analytical tools used in this thesis to analyse how the expansion of commodity frontiers is manifested in countryspecific trajectories of inequitable resource access (see Chapter 2). However, the research contained in this dissertation furthers political ecology knowledge on socio-environmental conflicts connected with the expansion of commodity frontiers by demonstrating that:

i) Resource control practices for the expansion of commodity frontiers occur, not only through 'accumulation by dispossession', but also through 'assimilation'. 'Assimilation' practices may be contested as much as practices of 'accumulation by dispossession' are, since they disarticulate the material and capabilities dimension of livelihoods from their meaning (identity) dimension.

ii) Access to resources is influenced, not only by systems of governance of resources, such as land tenure governance or forest management policies. The governmental support to extractive activities that facilitates the expansion of commodity frontiers also mediates power asymmetries in access to resources. It does so through both structural mechanisms of access (access to capital, knowledge and technology, and access to markets) and relational mechanisms (privileged access to the state). These structural and relational mechanisms of access constitute the strands of the power bundles through which actors interested in the expansion of a commodity frontier gain control over access to resources, while local populations lose control over resources or accept 'assimilation' practices in order to maintain their access.

iii) The expansion of commodity frontiers in contexts of agrarian struggle often transforms agrarian conflicts into socio-environmental conflicts. This is because such expansion threatens, not only local populations' access to land through physical dispossession, but also through the transformation of the environments that sustain their livelihoods. This change in the nature of conflicts corresponds with what Gerber and Veuthey (2010) have identified as the 'greening of the agrarian question', i.e. "the shift from traditional agrarian reform struggles to ecology-oriented conflicts... Because land is a natural resource, its appropriation, use and politics are embedded in ecological conditions, and hence linked with some kind or another of environmentalist question" (Gerber, 2010: 97; Gerber and Veuthey, 2010). 
iv) The dimensions of justice compromised by expansion of commodity frontiers (distribution, recognition, capabilities and participation) are present in the discursive frames used by local actors to articulate their resistance. They are also affected in practice, since threats to livelihood dimensions (material, meaning and capabilities) translate into injustices in terms of:

a. inequitable distribution of access resources,

b. lack of identity recognition,

c. lack of freedoms to pursue the lives people value to live, and

d. lack of participation in the decision-making about the use and distribution of the resources local people depend upon for their livelihoods.

v) Human rights are one of the valuation languages through which resistance is articulated in the case of socio-environmental conflicts. However, human rights also constitute a powerful vehicle for emancipatory politics against the expansion of commodity frontiers when their application and interpretation are based on a multicultural notion of human rights, i.e. an interpretation of human rights that reflects what these rights mean for local populations, and takes into account the multiple meanings these populations attach to the environments they inhabit. It is through such multicultural interpretation of human rights that different dimensions of justice can be achieved in specific local cases of socio-environmental conflict and resistance.

vi) Procedural power and plurality of values are relevant factors explaining why the resistance manifested in socio-environmental conflicts is reproduced as legitimacy contestation of non-state market-driven sustainability governance systems (like voluntary certification schemes) at the national level. This finding contributes, not only to the political ecology scholarship on socio-environmental conflicts connected with the expansion of commodity frontier, but also to the literature on legitimacy of NSMD sustainability governance systems. It demonstrates the relevance of integrating concepts from ecological economics and political ecology - valuation languages and procedural power - into the analysis of legitimacy of NSMD sustainability governance systems.

vii) Finally, a significant contribution of this dissertation to political ecology research is the construction of an analytical approach that can be applied to the study of the expansion of any commodity frontier in any country.

In this dissertation I pose that expansion of commodity frontiers follow country-specific trajectories of resources access control and resistance in producing countries, focusing on the 2000-2010 expansion of the palm oil frontier in Colombia and the resistance that it has elicited. As a consequence, the findings about the case of the expansion of the palm oil frontier of Colombia cannot be generalised. 
However, I constructed an analytical approach that incorporates different aspects that are key to composing the picture of the country-specific trajectories of inequitable access to resources connected with to the expansion of commodity frontiers. This approach can be summarised as:

i) Identify the practices of resource access control that result in inequitable outcomes (the different forms in which 'accumulation by dispossession', 'assimilation' or other type of practices manifest at the national and local levels).

ii) Identify the geographic, material (characteristics of the commodity and material requirements for its production), economic and socio-political factors that shape country-specific trajectories of resources access control.

iii) Identify the governmental support to the extractive activity and analyse ways in which it mediates power asymmetries in access to resources.

iv) Identify the effects of resource access control practices on local populations' livelihoods, and analyse how they affect different dimensions of justice.

v) Analyse whether and how governance mechanisms adopted to counteract the negative effects of the expansion of a commodity frontier allow participation and reflect the plural values of the local populations that may be affected; and

vi) Analyse the response of the local populations in defence of their livelihoods, as well as the mechanisms and strategies of resistance and contestation and their emancipatory potential.

\subsubsection{Political relevance in lieu of policy recommendations}

As explained in Chapter 2 (Section 2.4.3) the research from a political ecology perspective entails political engagement with environmental justice. That engagement may be with policy-making through formulating policy recommendations, or with the political action of subaltern groups by providing knowledge that is relevant for their strategies of resistance (Blaikie, 2012; Rocheleau, 2008).

I have one main policy recommendation regarding the case of Colombia analysed in this thesis as follows:

1. The establishment of oil palm plantations (or any other type of agro-industrial plantations) should be subject to both environmental licensing and prior and informed consultation with local populations and their consent.

At the moment, environmental licences and consultation with local populations are only required for mineral, oil and gas extraction projects, but not for agro-industrial plantations. Likewise, participation of local populations should be guaranteed in local and national 
decision-making processes aimed at adopting measures to stimulate oil palm cultivation or other type of agro-industrial plantations.

This recommendation is based on the evidence presented in this dissertation that the expansion of oil palm cultivation takes the form of enclaves, which produce socioenvironmental changes in entire geographical regions that substantially affect the lives of local populations and have environmental consequences.

I offer only one policy recommendation and I do not have high expectations about its implementation because I share Neumann's statement about the policy relevance of critical research: "policy relevance is only to a very small degree the responsibility of the critical researcher. Academic researchers, regardless of how they may try to make themselves relevant and to reach out to people, bureaucracies, and organizations in charge of making and implementing policy often find they have little power over how their work is or is not used. Whether or not such efforts will result in meaningful policy reform will depend upon 'where power lies and how it is used' (Blaikie, 1985: 6 quoted in Neumann, 2008: 734)" (Neumann, 2008: 734).

Following Neumann's logic, the close relations between the government and the palm oil agro-industry presented in Chapter 4 led me to conclude that policy recommendations based on the finding of this research might not be implemented. Therefore, offering policy recommendations in this thesis might have little or no impact on the situation of local populations whose livelihoods are threatened by the expansion of the palm oil frontier.

On the contrary, the achievements that these local populations have accomplished by challenging the structures that shape access to resources demonstrate that contributing to their emancipatory politics can be more fruitful for attaining social and environmental justice than policy recommendations. A way to contribute to such emancipatory politics is by engaging with the 'sociology of the absences' and the 'sociology of emergences' (see Chapter 2). I do so in this dissertation by:

i) Rendering visible the very distinct ways in which subaltern groups threatened and affected by the expansion of the palm oil frontier relate with the environmental resources that constitute the material basis of their livelihoods (Chapters 5 and 6);

ii) Unveiling the forms and means through which this difference is denied by dominant worldviews of resource use and land exploitation represented by agro-industrial oil palm cultivation (Chapters 3 and 4),

iii) Demonstrating that such denial produce grievances for local populations across different dimensions of justice (Chapter 5); and 
iv) Exposing the emancipatory potential of the resistance of these subaltern groups (Chapter 5).

It is my hope that through this route this research also reaches policy-makers and policyexecutors. In which case, I would have accomplished more than what I expected from this research project.

\subsection{Areas for future research}

I have identified four areas for future research as follows:

Firstly, more empirical research on the contract farming schemes called 'productive alliances'. One main contribution of this dissertation is to demonstrate that practices of resource access control for the expansion of commodity frontiers take, not only the form of 'accumulation by dispossession', but also of 'assimilation'.

In the case of Colombia, this dissertation shows that contract farming schemes used for expansion of oil palm cultivation - called 'productive alliances' - may embody 'assimilation' practices. However, the analysis carried out in this research as regards 'productive alliances' is rather limited. It only shows:

i) The role of 'productive alliances' in the expansion of oil palm cultivation between 2000 and 2010 (about 25\% of the new hectares cultivated with oil palm during this period was under the form of 'productive alliances');

ii) The socio-economic and political factors that favoured the use of 'productive alliances' for the expansion of the palm oil frontier; and

iii) The analysis of 'productive alliances' as a form of assimilation in one specific case (Case 3, Chapter 5).

However, the members of alliances are not a homogeneous group. There are many associations engaged in oil palm 'productive alliances' in Colombia (more than hundred), and the membership configuration of these associations is varied and complex. Moreover, the socio-economic, geographical and political contexts in which incorporation takes place may vary from one case to the other.

Therefore, 'productive alliances' require much more empirical research and analysis than that carried out in this thesis to assess the conditions under which such alliances embody 'assimilation' and/or incorporation in disadvantageous terms. 
There are also other aspects of 'productive alliances' that require further research:

1. How labour and benefits or disadvantages of participation are distributed along gender lines in 'productive alliances';

2. How internal politics of associations affects association's power position vis-a-vis the anchor palm oil company;

3. Whether and how the use of 'productive alliances' for the expansion of oil palm cultivation has facilitated:

a. Obtaining more institutional support (from government, multilateral organizations, development agencies and foreign aid) for the palm oil agroindustry; and

b. Projecting an image of the Colombian palm oil agro-industry as socially sustainable; and

4. The processes of peasant differentiation and agrarian change elicited by the spread of palm oil 'productive alliances' across the national rural geography.

Secondly, there is a need for studies that unpack the internal politics and differentiation of different categories of actors involved in socio-environmental conflicts and resistance connected with the expansion of the commodity frontiers (see Chapter 2, Section 2.4.2).

Thirdly, external conditions and factors influencing success or failure of emancipatory politics is an interesting topic for future research. By external factors I mean those that are not related to the organization of the resistance. Examples of external factors are de facto constraints to resistance (such as the threat of violence by armed actors), or the institutional environment (laws, regulations and the existence of state agencies that provide for protection of rights of local populations). For example, Bebbington (2012c) notes that more attention should be paid to counter-hegemonic movements within the state, the central government, the judiciary and the press that can support local populations' claims so influencing success of resistance strategies.

The factors underlying the emergence of resistance (or lack of it) have been analysed by political ecologists (Conde and Kallis, 2012). However, external conditions that may influence the success or failure of resistance have received less attention.

Fourthly, there is a need for more empirical research on the implementation of NSMD sustainability governance mechanisms at the national and local levels. The analysis on RSPO in Colombia presented in Chapter 6 was limited to the process of national interpretation because at the time of the research there was not data available on the implementation through the certification mechanism. Empirical research on the implementation of the certification mechanism and its outcomes would shed light on the 
potential of the NSDM mechanisms to modify unsustainable practices and gain legitimacy among local populations. 


\section{Epilogue}

\section{Overview of Country-specific Trajectories of Expansion of the Palm Oil Frontier in Colombia after 2010}

In this dissertation I analyse the country-specific trajectories of the expansion of the palm oil frontier in Colombia and the resistance and socio-environmental conflicts connected with such expansion. Since the expansion of the palm oil frontier is an ongoing process, this thesis focuses on the period between 2000 and 2010 for practical reasons (see Section 2.4.2.2 in Chapter 2). However, I provide a brief update in this epilogue of the most relevant developments after 2010 to the end of 2013 regarding the four topics analysed in this thesis:

i) the country-specific trajectories of expansion and resource access control of the palm oil frontier in both the space-of-flows and the space-of-place;

ii) the governmental support to the palm oil agro-industry that mediates power asymmetries in access to resources;

iii) the grievances suffered by local populations in connection with the expansion of the palm oil frontier and the resulting resistance and conflicts; and

iv) the legitimacy of the non-state market-driven sustainability governance of the palm oil agro-industry in Colombia represented by the RSPO certification mechanism.

$i$. The country-specific trajectories of expansion and resource access control of the palm oil frontier in Colombia after 2010:

The country-specific trajectories of expansion presented in Chapter 3 have not changed significantly after 2010. Palm oil production has continued to increase from 753,000 tonnes in 2010 to 1,041,000 tonnes in 2013 (CONtextoganadero, 2014; Fedepalma, 2011a). Most of the national palm oil production has been directed to the national market, since palm oil demand for national biodiesel production has continued to increase. The national biodiesel industry absorbed $40 \%$ of the palm oil production in 2011 (Fedepalma, 2012a), and about 45\% in 2012 and 2013 (CONtextoganadero, 2014; Fedepalma, 2013a). This is explained by the gradual implementation of the $10 \%$ biodiesel blending mandate as of 2008 (see Chapter 4). The average percentage of biodiesel in the transport fuel mix at the national level was $7.12 \%$ in $2010,8 \%$ in 2011, and $9.2 \%$ in 2012 and 2013.

Although the national biodiesel industry has absorbed most of the increased production of palm oil since 2008, exports started to rise in 2011 because: 
a. the palm oil demand for national biodiesel production is reaching its maximum as the biodiesel blend approaches to the $10 \%$ mandate, and

b. the demand for palm oil from the traditional national market (food, oleochemical, soaps and animal feed) has not absorbed the palm oil surplus (Fedepalma, 2012a).

Therefore, the palm oil agro-industry has sought to sell the surplus in exports markets. The most important export destination has been The Netherlands. Over $40 \%$ of the crude palm oil exports in 2011 and 2012 were destined to the Netherlands (42\% in 2011 and 48\% in 2012). Palm oil consumption increased substantially in the Netherlands in 2012. 'Domestic disappearance' of palm oil in this country increased from about 600,000 tonnes in 2011 to 1.3 million tonnes in 2012. ${ }^{1}$ According to some analysts this increase in palm oil use in the Netherlands is to a large extent connected with an increase in biodiesel production. In 2011 the Finland-based company Neste Oil opened a new biodiesel plant in Rotterdam with capacity to process 0.8 million tonnes of vegetable oils per year. It is estimated that the Neste Oil plant in Rotterdam consumed 0.4 million tons of palm oil in 2012 (Gerasimchuk and Koh, 2013).

Along with the increase in palm oil production, the area cultivated with oil palm has also increased from 404,000 hectares in 2010 to 477,000 hectares in 2013. (Fedepalma, 2011a; CONtextoganadero, 2014). Like in the 2000-2010 period, after 2010 the array of land control practices displayed to expand oil palm cultivation include legitimate acquisition, 'productive alliances' as well as forms of 'accumulation by dispossession'.

For example, a new case of 'accumulation by dispossession' came into public domain in 2013. It is the case of a land dispute between an oil palm grower and twenty peasant families of the area called vereda Pitalito in the municipality of Chimichagua-Cesar (North Region of the palm oil geography) (Verdad Abierta, 2013c).

This case resembles the conflict between the members of ASOCAB and El Labrador Consortium for the land of Las Pavas (see Chapter 5). Since January 2010, an oil palm grower claims the ownership of the land that the peasant families of vereda Pitalito have occupied for several years. The peasant families were evicted from the land in June 2010. In May 2013, the families of vereda Pitalito decided to return peacefully to the land as a form of resistance. However, they were evicted for the second time in October 2013 (Verdad Abierta, 2013c and 2013d).

Land control through 'productive alliances' has continued also to increase in new frontiers, as illustrated by the case of Oleoflores business group. The land cultivated under

\footnotetext{
1 "The term 'domestic disappearance' is largely synonymous with consumption, but also includes losses and waste" (Gerasimchuk and Koh, 2013: 7).
} 
'productive alliances' linked to Oleoflores increased from about 25,000 hectares in 2011 to about 38,000 hectares in 2013 (Dangond, 2013). ${ }^{2}$ Most of this expansion has taken place in new frontiers in the regions of Catatumbo (Central Region of the palm oil geography) and Montes de María (North Region of the palm oil geography). In Catatumbo and Montes de María land control through 'productive alliances' combines with 'accumulation by dispossession'. As these two regions have gradually taken the form of palm oil enclaves, livelihood dispossession of the local population has started to be reported (Coronado and Dietz, 2013; Correa et al., 2012; Gómez López, 2010; Molano Bravo, 2012).

An important trajectory of oil palm cultivation between 2011 and 2013 has been the removal and renewal of plantations affected by the 'bud rot' disease. ${ }^{3}$ In 2010 , this disease had already affected about 40,000 hectares. By the end of 2013, the number of hectares affected by the 'bud rot' had reached more than 70,000; all of them located in the Southwest and Central Regions of the palm oil geography (MADR, et al., 2014). Therefore, controlling the spread of the disease, as well as removing and renewing the oil palms affected, has become a priority for the palm oil agro-industry. By the end of 2013, about 40,000 hectares of oil palm affected by the 'bud rot' had been removed and about 19,000 hectares had been renewed (MADR et al., 2014).

ii) Governmental support to the palm oil agro-industry mediating power asymmetries in access to resources after 2010:

Although the government changed in 2010 (Juan Manuel Santos was elected as President), this change has not affected the palm oil agro-industry's 'privileged access to the government' (see Chapter 4). Like in Uribe Vélez's government, members of families involved in the business of oil palm cultivation and palm oil production have also been part of Santos's government (see Table C.3 in Appendix C).

Like in Uribe Vélez's government, experts and managers that used to work for the palm oil agro-industry have also been appointed for leading positions in Santos's government, in particular, leading positions at the Ministry of Agriculture and Rural Development (MADR). A former economic director of Fedepalma, who had become director of agricultural policy at the MADR during the first government of Álvaro Uribe Vélez, was appointed as Vice-minister of Agriculture during the first two years of Santos's government (2010-2012). Moreover, the person who had been the Chief Executive Officer for twenty

\footnotetext{
${ }^{2}$ In the Oleoflores website is reported that by 30 September 2011, there were 25,133 hectares with oil palm under 'productive alliances' linked to Oleoflores. See Oloeflores website http://www.oleoflores.com/alianzas.html\#content12 (accessed March 23, 2014).

${ }^{3}$ See Section 3.4.1.1 in Chapter 3 (footnote 9) for more details about the 'bud rot' disease.
} 
years of the large-scale palm oil company Indupalma - Rubén Darío Lizarralde - was appointed as Minister of Agriculture and Rural Development in September 2013.

The palm oil agro-industry has also continued to benefit largely from agricultural soft credit and subsidies during Santos's government. For example, the amount of agricultural soft credit received by the palm oil agro-industry increased in 2011 and 2012 with respect to 2010 (Fedepalma, 2012a and 2013b). The amount of credit granted in 2011 for financing oil palm growing activities showed an increase of $48 \%$ with respect to 2010 (Fedepalma, 2012a).

Even though the Minister of Agriculture Juan Camilo Restrespo (August 2010 - June 2013) introduced some changes to the rules governing the assignment of subsidies that were key to the 2000-2010 expansion of the palm oil frontier, oil palm growers have continued to benefit from subsidies.

Juan Camilo Restrepo created a programme called Equitable Rural Development - DRE (Desarrollo Rural con Equidad) as a substitute for the AIS programme (Agro Ingreso Seguro). Under the DRE programme, the Rural Capitalisation Incentive (ICR) could no longer be granted to large-scale oil palm growers, unless they were in 'productive alliances' with small-scale growers. Likewise, large-scale growers could not have access to subsidies for irrigation and drainage under the DRE programme.

However, rather than reducing access to the ICR by the palm oil agro-industry, the government adjusted the application of the subsidy to the needs of this agro-industry. For example, the MADR allocated COP 210,000 million (about US\$ 105 million) in 2013 to be destined to assist the palm oil agro-industry in the removal and renewal of the hectares of oil palm affected by the 'bud rot' disease (CONtextoganadero, 2013). This amount is being granted in the form of ICR to oil palm growers whose plantations have been affected by the disease.

Other governmental decisions and measures to protect or favour the industry include:

a. A reduction of the Value Added Tax (VAT) applied to the sales of crude palm oil. This measure benefits palm oil producers that vertically integrate palm oil production with processing activities such as biodiesel production (Fedepalma, 2012b).

b. The establishment of trade barriers to imports from Argentina of refined soy and sunflower oils in order to protect the national palm oil commodity chain (CONtextoganadero, 2014).

c. The declaration of tax free zones of two more palm oil mills - Extractora la Gloria s.a.s and Extractora Loma Fresca Sur de Bolívar s.a - (MCIT, 2013). 
iii. The grievances suffered by local populations in connection with the expansion of the palm oil frontier and the resulting resistance and conflicts:

As presented in section i) above, after the 2010 'productive alliances' have continued to be an important land control practice for the expansion of the palm oil frontier. However, some cases of 'adverse incorporation' and negative impacts for small-scale growers have started to emerge. For example, the members of a 'productive alliance' linked to Indupalma in the municipality of Sabana de Torres (Central Region) argue that the benefits promised had not been realised. They claim that:

a. They have not received the payments for the sale of the oil palm fresh fruit bunches in the terms that were agreed with Indupalma, and

b. They are highly indebted and hence at the edge of losing their lands (Vanguardia, 2012).

In the municipality of Tumaco (South-west Region) the small-scale growers affected by the 'bud rot' disease had to use a method for removal of the affected palms cheaper than the method used by large-scale growers. However, the cheaper method involves the use of chemicals that are affecting the small-scale growers and the local population in general. Instead, large-scale growers used backhoes to remove the affected palms. This is costly, but less harmful than chemical methods (Bermúdez Liévano, 2013).

Expansion of the palm oil frontier after 2010 has proceeded in some cases through land control practices of 'accumulation by dispossession' affecting local population's livelihoods (see point (i) above). However, there is a positive development during Juan Manuel Santos's government regarding cases of land dispossession. The emphasis that the government of Juan Manuel Santos put on land restitution has led to:

a. The investigation and discovery of land control practices of 'accumulation by dispossession' for the expansion of the palm frontier involving unlawful accumulation of land by large-scale oil palm growers (see Chapter 3 and Cases 11-16 in Table B.1 Appendix B.

b. Decisions from The Colombian Institute for Rural Development (INCODER) - the governmental agency in charge of clarifying the ownership of land in rural areas that have favoured peasant claims for access to land in cases involving large-scale oil palm growers or palm oil producers. This is the situation in the cases of Las Pavas estate (see Chapter 5 and Case 3 in Table B.1 Appendix B.2) and La Bellacruz estate (Case 4 in Table B.1 Appendix B.2).

These investigations and decisions took place under the leadership of Juan Camilo Restrepo as Minister of Agriculture and Rural Development, who appointed Miriam Villegas as the 
director of the INCODER. Miriam Villegas had worked for the Corporation Development and Peace of the Magdalena Medio (CDPMM) for several years. Hence, she was aware of the claims and needs of the peasant population. ${ }^{4}$

Under Miriam Villegas direction, the INCODER prioritized the land tenure clarification of the contested lands in the estates of Las Pavas and La Bellacruz and found that, to a great extent, they were public lands which the state could assign to peasant population according to the Colombian Agrarian Law (INCODER, 2012a, 2012b and 2012c). Since the state's ownership over land in Las Pavas and La Bellacruz estates was asserted by the INCODER, the peasants involved in the disputes with oil palm growers could start the procedure for the recognition of their tenure rights.

iv) The legitimacy of the non-state market-driven sustainability governance of the palm oil agro-industry in Colombia represented by the RSPO (Roundtable on Sustainable Palm Oil) certification mechanism:

The process of the Colombian National Interpretation of the RSPO Principles and Criteria was adopted in November 2010. However, by the end of 2013, there was only one palm oil producer certified (C.I Tequendama owned by DAABON group).

The RSPO international standard was revised in 2103. As a consequence, the RSPO system requested the revision of the National Interpretation by April 2014 in order to adjust it to the revised international standard. A difference with the previous National Interpretation process in Colombia (see Chapter 6 ) is that the revision process is led by a large-scale palm oil producer (DAABON group) rather than by Fedepalma (RSPO, 2013).

Another difference is the inclusion in the working group in charge of the revision process of more organizations representing social and environmental interests (see RSPO, 2013 for details about the composition of the working group).

It is particularly interesting that Indepaz has been included in the working group as a representative of the social interests. Indepaz is a Colombian NGO that participated in the evaluation of the Colombian National Interpretation process commissioned by OxfamNovib (see Chapter 6). In this evaluation, Indepaz had included a detailed review of the weaknesses of both the National Interpretation and the process to adopt it (Seebolt and Salinas, 2010). Therefore, the participation of Indepaz in the revision process may help to overcome such weaknesses.

\footnotetext{
${ }^{4}$ Miriam Villegas was the coordinator of the CDPMM programme Finca Campesina con Palma. She left the direction of the INCODER when Rubén Darío Lizarralde was appointed as Minister of Agriculture and Rural Development in September 2013. See also Chapter 5 for more information about CDPMM's support to peasant associations.

${ }^{5}$ See Section 3.4.2.2 in Chapter 3 for some details about the assignment of public lands to peasants according to the Colombian Agrarian Law.
} 


\section{Appendix A}

\section{List of interviews and meetings during fieldwork in Colombia}

Table A.1. List of interviews and group meetings during exploratory fieldwork in Colombia, January - February 2010

\begin{tabular}{|c|c|c|c|c|c|}
\hline \multicolumn{2}{|c|}{ Category } & \multirow{2}{*}{$\begin{array}{l}\text { Institution or organization } \\
\text { Office of the Ombudsman }\end{array}$} & \multirow{2}{*}{$\begin{array}{c}\text { Type of } \\
\text { interview/meeting } \\
\text { In-depth interview }\end{array}$} & \multirow{2}{*}{$\begin{array}{l}\text { Interviewee/participant(s) } \\
\text { Officer collective rights }\end{array}$} & \multirow{2}{*}{$\begin{array}{l}\text { Place and date } \\
\text { Bogotá, } \\
\text { January } 20,2010\end{array}$} \\
\hline Government \& & National & & & & \\
\hline & \multirow[t]{2}{*}{ Local } & $\begin{array}{l}\text { Office of the Mayor of } \\
\text { Barrancabermeja }\end{array}$ & In-depth interview & Mayor & $\begin{array}{l}\text { Barrancabermeja-Santander, } \\
\text { February } 3,2010\end{array}$ \\
\hline & & $\begin{array}{l}\text { Agricultural Technical } \\
\text { Assistance Unit of the } \\
\text { municipality of } \\
\text { Barrancabermeja }\end{array}$ & In-depth interview & Officer & $\begin{array}{l}\text { Barrancabermeja-Santander } \\
\text { February 4, } 2010\end{array}$ \\
\hline & \multirow[t]{3}{*}{ Regional } & $\begin{array}{l}\text { Secretariat of Agriculture of } \\
\text { Meta Province }\end{array}$ & In-depth interview & $\begin{array}{l}\text { Tow persons: the coordinator of productive } \\
\text { chains and the officer in charge of the biofuel } \\
\text { productive chain }\end{array}$ & $\begin{array}{l}\text { Villavicencio-Meta } \\
\text { February } 16,2010\end{array}$ \\
\hline & & $\begin{array}{l}\text { Cormacarena } \\
\text { (regional environmental } \\
\text { authority for Meta } \text { Province) } \\
\end{array}$ & In-depth interview & Officer & $\begin{array}{l}\text { Villavicencio-Meta } \\
\text { February } 17,2010\end{array}$ \\
\hline & & $\begin{array}{l}\text { Regional Office of the } \\
\text { Ombudsman Meta Province }\end{array}$ & In-depth interview & Regional Ombudsman & $\begin{array}{l}\text { Villavicencio-Meta } \\
\text { February } 16,2010 \\
\end{array}$ \\
\hline \multirow{2}{*}{$\begin{array}{l}\text { Palm oil agro- } \\
\text { industry and } \\
\text { biodiesel industry }\end{array}$} & \multirow{2}{*}{$\begin{array}{l}\text { Large-scale palm oil } \\
\text { producers/oil palm } \\
\text { growers }\end{array}$} & $\begin{array}{l}\text { Palmas Oleaginosas Bucarelia } \\
\text { s.a. }\end{array}$ & In-depth interview & Manager mill & $\begin{array}{l}\text { Puerto Wilches- Santander, } \\
\text { February 3, } 2010\end{array}$ \\
\hline & & Oleaginosas Las Brisas s.a. & In-depth interview & $\begin{array}{l}\text { Employee - department corporate social } \\
\text { responsibility plantation and mill }\end{array}$ & $\begin{array}{l}\text { Puerto Wilches- Santander } \\
\text { February 3, } 2010\end{array}$ \\
\hline \multirow{3}{*}{\multicolumn{2}{|c|}{$\begin{array}{l}\text { Associations of small-scale oil palm growers } \\
\text { part of the programme Finca Campesina } \\
\text { con Palma }\end{array}$}} & APALSA & In-depth interview & Director and member of the association & $\begin{array}{l}\text { San Pablo-Bolívar, } \\
\text { February 2, } 2010\end{array}$ \\
\hline & & & Group meeting & Four members of the association & $\begin{array}{l}\text { San Pablo-Bolívar } \\
\text { February 2, } 2010\end{array}$ \\
\hline & & ASOPEPA & In-depth interview & Director and member of the association & $\begin{array}{l}\text { Puerto Wilches- Santander } \\
\text { February 3, } 2010\end{array}$ \\
\hline
\end{tabular}




\begin{tabular}{|c|c|c|c|c|c|}
\hline \multirow{2}{*}{\multicolumn{2}{|c|}{ Local leaders }} & $\begin{array}{l}\text { Asociación Departamental de } \\
\text { Usuarios Campesinos } \\
\text { (Regional peasant association of } \\
\text { the Meta } \text { Province) }\end{array}$ & In-depth interview & Two members of the association & $\begin{array}{l}\text { Villavicencio-Meta } \\
\text { February } 16,2010\end{array}$ \\
\hline & & $\begin{array}{l}\text { Macupaz } \\
\text { (Workgroup on environment and } \\
\text { peace culture in the Meta } \\
\text { Province) }\end{array}$ & In-depth interview & Two members of Macupaz & $\begin{array}{l}\text { Villavicencio-Meta } \\
\text { February } 16,2010\end{array}$ \\
\hline \multirow[t]{7}{*}{ NGOs } & Local & $\begin{array}{l}\text { Fundación Fruto Social de la } \\
\text { Palma-Puerto Wilches }\end{array}$ & In-depth interview & Director & $\begin{array}{l}\text { Puerto Wilches- Santander, } \\
\text { February } 3,2010\end{array}$ \\
\hline & \multirow[t]{6}{*}{ Regional } & \multirow[t]{6}{*}{ CDPMM } & In-depth interview & $\begin{array}{l}\text { Coordinator of the programme Finca } \\
\text { Campesina con Palma }\end{array}$ & $\begin{array}{l}\text { Bogotá, } \\
\text { January 23, } 2010\end{array}$ \\
\hline & & & In-depth interview & $\begin{array}{l}\text { Agronomic coordinator of the programme } \\
\text { Finca Campesina con Palma }\end{array}$ & $\begin{array}{l}\text { Barrancabermeja-Santander, } \\
\text { February } 4,2010\end{array}$ \\
\hline & & & In-depth interview & $\begin{array}{l}\text { Regional coordinator environment and } \\
\text { sustainable development }\end{array}$ & $\begin{array}{l}\text { Barrancabermeja-Santander, } \\
\text { February } 4,2010\end{array}$ \\
\hline & & & In-depth interview & $\begin{array}{l}\text { Regional coordinator sustainable productive } \\
\text { processes }\end{array}$ & $\begin{array}{l}\text { Barrancabermeja-Santander, } \\
\text { February } 4,2010\end{array}$ \\
\hline & & & In-depth interview & $\begin{array}{l}\text { Coordinator of the CDPMM's land protection } \\
\text { project }\end{array}$ & $\begin{array}{l}\text { Barrancabermeja-Santander, } \\
\text { February } 4,2010\end{array}$ \\
\hline & & & In-depth interview & $\begin{array}{l}\text { Coordinator of the CDPMM's peace } \\
\text { observatory }\end{array}$ & $\begin{array}{l}\text { Barrancabermeja-Santander, } \\
\text { February } 4,2010\end{array}$ \\
\hline \multirow[t]{3}{*}{ Key Informants } & Practitioners & & $\begin{array}{l}\text { Meeting in } \\
\text { preparation for } \\
\text { fieldwork }\end{array}$ & $\begin{array}{l}\text { Yamile Salinas Abdala } \\
\text { (consultant and legal expert on environmental } \\
\text { and human rights issues) }\end{array}$ & $\begin{array}{l}\text { Bogotá, } \\
\text { January } 19,2010\end{array}$ \\
\hline & \multirow[t]{2}{*}{ Researchers } & Unillanos University & In-depth interview & Lecturer & $\begin{array}{l}\text { Villavicencio-Meta } \\
\text { February } 17,2010\end{array}$ \\
\hline & & $\begin{array}{l}\text { Escuela de Administración } \\
\text { Pública de Villavicencio (Public } \\
\text { Administration School of } \\
\text { Villavicencio) }\end{array}$ & In-depth interview & Lecturer & $\begin{array}{l}\text { Villavicencio-Meta } \\
\text { February } 16,2010\end{array}$ \\
\hline
\end{tabular}




\begin{tabular}{|c|l|l|l|l|l|}
\hline Key Informants & $\begin{array}{l}\text { From international } \\
\text { organizations }\end{array}$ & $\begin{array}{l}\text { United Nations Development } \\
\text { Programme Colombia - Meta } \\
\text { office }\end{array}$ & $\begin{array}{l}\text { Meeting in } \\
\text { preparation for } \\
\text { interviews }\end{array}$ & Director & $\begin{array}{l}\text { Villavicencio-Meta } \\
\text { February 15, 2010 }\end{array}$ \\
\cline { 3 - 5 } & $\begin{array}{l}\text { Office of the United Nations } \\
\text { High Commissioner for } \\
\text { Refugees Colombia }- \text { Meta } \\
\text { office }\end{array}$ & In-depth interview & Officer & $\begin{array}{l}\text { Villavicencio-Meta } \\
\text { February 17, 2010 }\end{array}$ \\
\hline
\end{tabular}

Note 1: the exploratory fieldwork also included the organization of, and participation in, a workshop held in Bogotá on 25 February 2010 with the participation of representatives of the palm oil agro-industry, the biofuel industry, the academia, civil society organizations, and governmental agencies.

Note 2: the exploratory fieldwork was carried out with funds from the CoCooN programme of the Netherlands Organisation for Scientific Research. The preliminary research proposal for a project called "Agrofuels, a recipe for conflict? The case of Colombia from a global to local perspective" was positively evaluated to pass to the second round of the first call for proposals of the CoCooN programme. Some funding was granted to carry out stakeholder consultation in order to prepare the complete research proposal. The field visits, interviews and meetings carried out for the stakeholder consultation constituted the exploratory fieldwork for this thesis. However, the complete proposal was not selected for full funding.

The exploratory fieldwork was carried out with the support of the two Colombian partners of the consortium formed for the research proposal: the NGO Grupo Semillas and the Cinara Institute - University of Valle. In particular the following persons: Paula Álvarez and Lina Forero (Grupo Semillas), Mario Alejandro Pérez and Paola Arias (Cinara Institute - University of Valle). 
Table A.2. List of interviews and group meetings during fieldwork in Colombia, August - December 2011

\begin{tabular}{|c|c|c|c|c|c|}
\hline \multicolumn{2}{|c|}{ Category } & $\begin{array}{l}\text { Institution or } \\
\text { organization }\end{array}$ & $\begin{array}{l}\text { Type of } \\
\text { interview/meeting }\end{array}$ & Interviewee/participant(s) & Place and date \\
\hline \multirow[t]{2}{*}{$\begin{array}{l}\text { Government \& } \\
\text { state institutions }\end{array}$} & Local & $\begin{array}{l}\text { Office of the Mayor of San } \\
\text { Alberto }\end{array}$ & In-depth interview & Director of projects & $\begin{array}{l}\text { San Alberto, } \\
\text { September } 8,2011\end{array}$ \\
\hline & National & $\begin{array}{l}\text { Ministry of Environment, } \\
\text { Housing and Territorial } \\
\text { Development }\end{array}$ & In-depth interview & $\begin{array}{l}\text { Officer within the division: sector-specific } \\
\text { sustainable development. }\end{array}$ & $\begin{array}{l}\text { Bogotá, } \\
\text { November 8, } 2011\end{array}$ \\
\hline \multirow[t]{3}{*}{$\begin{array}{l}\text { Palm oil agro- } \\
\text { industry and } \\
\text { biodiesel industry }\end{array}$} & \multirow[t]{2}{*}{$\begin{array}{l}\text { Federations of } \\
\text { producers }\end{array}$} & Fedepalma & In-depth interview & $\begin{array}{l}\text { Leader of the 'social division' within the } \\
\text { department of 'Sector Planning and Sustainable } \\
\text { Development' }\end{array}$ & $\begin{array}{l}\text { Bogotá, } \\
\text { October 18, } 2011\end{array}$ \\
\hline & & Fedebiocombustibles & In-depth interview & Member of the Board of Directors & $\begin{array}{l}\text { Bogotá, } \\
\text { November 10, } 2011\end{array}$ \\
\hline & $\begin{array}{l}\text { Large-scale palm oil } \\
\text { producers/oil palm } \\
\text { growers }\end{array}$ & Indupalma & In-depth interview & Business development director & $\begin{array}{l}\text { Bogotá, } \\
\text { October 31, } 2011\end{array}$ \\
\hline \multirow{4}{*}{\multicolumn{2}{|c|}{ Peasant associations }} & \multirow[t]{3}{*}{ ASOPRODAGRO PC } & Group meeting & $\begin{array}{l}\text { Five members of ASOPRODAGRO PC } \\
\text { (representing four families) }\end{array}$ & $\begin{array}{l}\text { San Alberto, } \\
\text { September 4, } 2011\end{array}$ \\
\hline & & & In-depth interview & $\begin{array}{l}\text { Two members of ASOPRODAGRO PC } \\
\text { (representing one family) }\end{array}$ & $\begin{array}{l}\text { San Alberto, } \\
\text { September 4, } 2011\end{array}$ \\
\hline & & & Group meeting & $\begin{array}{l}\text { Twelve members of ASOPRODAGRO PC } \\
\text { (representing twelve families) }\end{array}$ & $\begin{array}{l}\text { San Alberto, } \\
\text { September } 8,2011\end{array}$ \\
\hline & & ASOBENPRO & Group meeting & Five leaders of ASOBENPRO & $\begin{array}{l}\text { Sabana de Torres, } \\
\text { September } 13,2011\end{array}$ \\
\hline
\end{tabular}




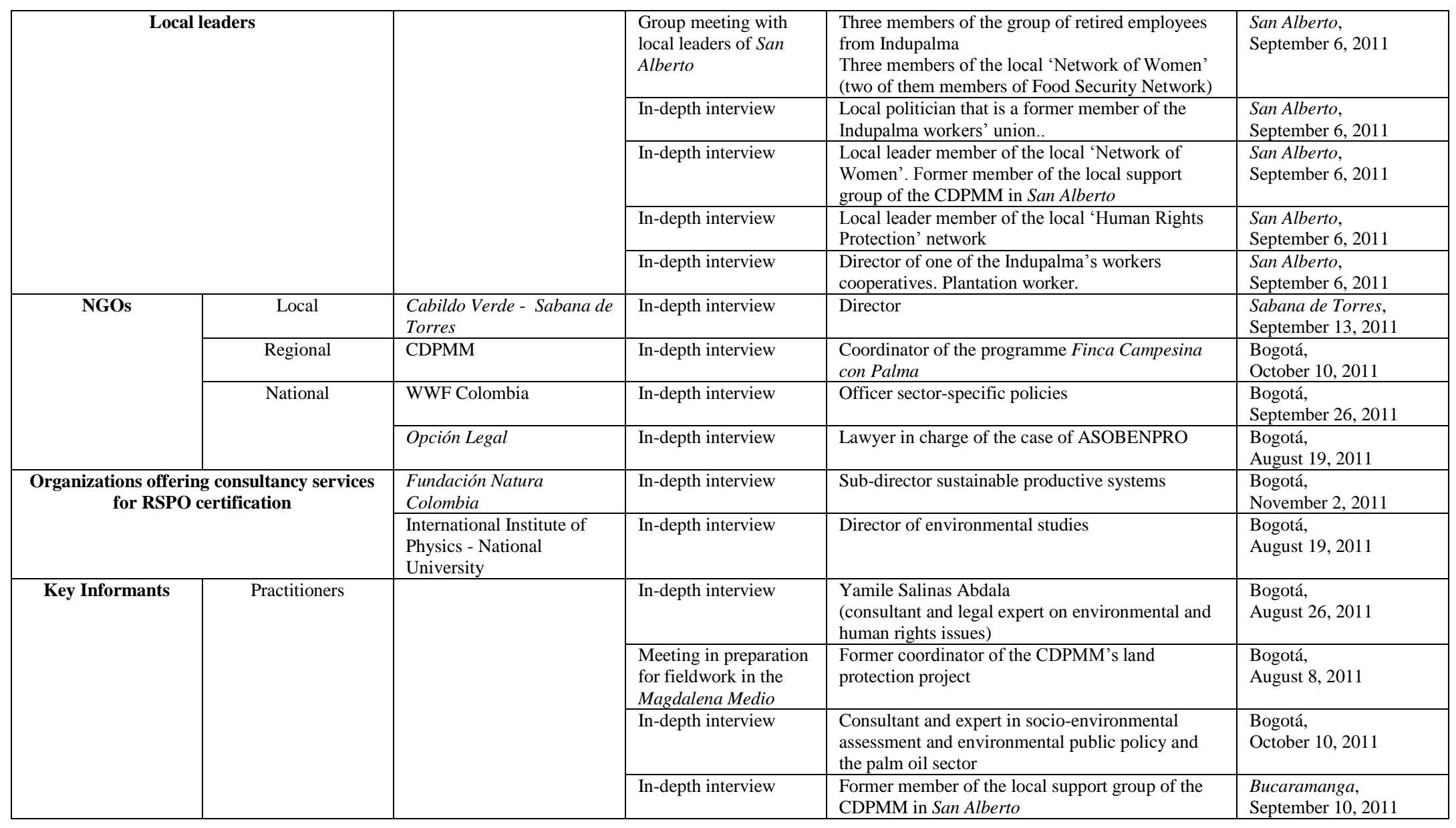




\begin{tabular}{|c|c|c|c|c|c|}
\hline \multirow[t]{6}{*}{ Key Informants } & \multirow[t]{3}{*}{ Researchers } & Externado University & In-depth interview & $\begin{array}{l}\text { Dario Fajardo (lecturer and researcher on agrarian } \\
\text { policy, peasant economies and food security) }\end{array}$ & $\begin{array}{l}\text { Bogotá, } \\
\text { August 23, } 2011\end{array}$ \\
\hline & & $\begin{array}{l}\text { Alexander Von Humboldt } \\
\text { Institute for Research on } \\
\text { Biological Resources }\end{array}$ & In-depth interview & Planning and evaluation officer & $\begin{array}{l}\text { Bogotá, } \\
\text { November 3, } 2011\end{array}$ \\
\hline & & $\begin{array}{l}\text { Observatory of Ethnic } \\
\text { Territories - Javeriana } \\
\text { University }\end{array}$ & In-depth interview & Researcher & $\begin{array}{l}\text { Bogotá, } \\
\text { November 4, } 2011\end{array}$ \\
\hline & \multirow[t]{3}{*}{ From NGOs } & Grupo Semillas & $\begin{array}{l}\text { Meetings in } \\
\text { preparation for } \\
\text { fieldwork }\end{array}$ & $\begin{array}{l}\text { Coordinator area trade, environment and public } \\
\text { policy }\end{array}$ & $\begin{array}{l}\text { Bogotá, } \\
\text { August } 11 \text { and 18, } 2011\end{array}$ \\
\hline & & SWISSAID Colombia & In-depth interview & $\begin{array}{l}\text { Programme coordinator (carried out research on the } \\
\text { effects of expansion of oil palm plantations in } \\
\text { Simiti-Bolivar). }\end{array}$ & $\begin{array}{l}\text { Bogotá, } \\
\text { August 23, } 2011\end{array}$ \\
\hline & & $\begin{array}{l}\text { Corporación Obusinga and } \\
\text { Corporación Compromiso }\end{array}$ & $\begin{array}{l}\text { Meeting in preparation } \\
\text { for fieldwork in the } \\
\text { Magdalena Medio }\end{array}$ & Directors of each corporation & $\begin{array}{l}\text { Bucaramanga, } \\
\text { August 31, } 2011\end{array}$ \\
\hline
\end{tabular}

Note: I also attended the following meetings and forums as participant observer:

1) "Dialogo sobre Proyecto de Ley Desarrollo Rural" (October 5, 2011).

2) International colloquium "Territorios Étnicos y Autonomía en América Latina" (November 9-11, 2011). 


\section{Appendix B}

\section{Details of the cases of 'accumulation by dispossession' presented in Chapter 3}

Table B.1. Details of the cases of 'accumulation by dispossession' presented in Table 3.4 in Chapter 3

\begin{tabular}{|c|c|c|c|c|c|c|}
\hline \multirow[t]{2}{*}{ Case } & \multirow[b]{2}{*}{$\begin{array}{c}\text { Geographical } \\
\text { area } \\
\text { (Region in the } \\
\text { palm oil } \\
\text { geography) }\end{array}$} & \multicolumn{2}{|r|}{ Actors } & \multirow{2}{*}{$\begin{array}{c}\text { Organizations } \\
\text { supporting and } \\
\text { advancing claims of } \\
\text { local actors }\end{array}$} & \multirow[b]{2}{*}{$\begin{array}{c}\text { Year oil palm } \\
\text { expansion starts } \\
\text { or land } \\
\text { appropriation } \\
\text { takes place } \\
\end{array}$} & \multirow[t]{2}{*}{ Source } \\
\hline & & $\begin{array}{c}\text { Local population } \\
\text { affected }\end{array}$ & $\begin{array}{l}\text { Palm oil producers/growers } \\
\text { and government }\end{array}$ & & & \\
\hline $\begin{array}{l}\text { 1. Afro-Colombian territories in the } \\
\text { Jiguamiandó and Curvaradó rivers } \\
\text { basins. Forced displacement and } \\
\text { ecological damage in the collective } \\
\text { territories of Afro-Colombian } \\
\text { communities. Following their eviction } \\
\text { and internal displacement operated by } \\
\text { paramilitary groups, companies started } \\
\text { oil palm cultivation projects on the } \\
\text { lands left by displaced people. At the } \\
\text { time of writing twenty one people were } \\
\text { under criminal judgment linked to these } \\
\text { incidents, including representatives and } \\
\text { shareholders of palm oil companies. }\end{array}$ & $\begin{array}{l}\text { Municipality of } \\
\text { Carmen del } \\
\text { Darién-Chocó. } \\
\text { (North Region) }\end{array}$ & $\begin{array}{l}\text { Afro-Colombian } \\
\text { communities }\end{array}$ & $\begin{array}{l}\text { Illegal paramilitary groups } \\
\text { and multiple oil palm } \\
\text { cultivation and palm oil } \\
\text { production companies }\end{array}$ & $\begin{array}{l}\text {-Proceso de } \\
\text { Comunidades Negras } \\
\text { (PCN) } \\
\text {-Comisión } \\
\text { Intereclesial de } \\
\text { Justicia y Paz } \\
\text { - Defensoría del } \\
\text { Pueblo (Ombudsman } \\
\text { Office) }\end{array}$ & 2000 & $\begin{array}{l}\text { Constitutional Court of } \\
\text { Colombia, 2010a; } \\
\text { Defensoría del Pueblo, } \\
\text { 2005; Franco and } \\
\text { Restrepo, 2011; ICHR, } \\
2008 \text {; Alfonso et al., } \\
2011 . \\
\text { Interview with officer } \\
\text { from the Office of the } \\
\text { Ombudsman during } \\
\text { fieldwork in 2010. }\end{array}$ \\
\hline $\begin{array}{l}\text { 2. Forced displacement and oil palm } \\
\text { cultivation in the areas of Monterrey } \\
\text { and San Blas. }\end{array}$ & $\begin{array}{l}\text { Municipality of } \\
\text { Simití-Bolívar } \\
\text { (Central Region) }\end{array}$ & $\begin{array}{l}\text { Small-holding } \\
\text { peasants, landless } \\
\text { peasants }\end{array}$ & $\begin{array}{l}\text { Illegal paramilitary group led } \\
\text { by alias 'Macaco' that created } \\
\text { a company for oil palm } \\
\text { cultivation (Corpoagrosur) }\end{array}$ & $\begin{array}{l}\text { Corporación } \\
\text { Desarrollo y Paz del } \\
\text { Magdalena Medio - } \\
\text { CDPMM } \\
\end{array}$ & 2002 & $\begin{array}{l}\text { Álvarez, 2009; Fiscalía } \\
\text { General de la Nación, } \\
\text { 2009; Presidencia de la } \\
\text { República, } 2010 .\end{array}$ \\
\hline $\begin{array}{l}\text { 3. Las Pavas estate. } \\
\text { Land dispute. Expansion of oil palm } \\
\text { cultivation in the area of Papayal } \\
\text { Island. Eviction of peasants from areas } \\
\text { they use for their livelihood. Ecological } \\
\text { damage to the marshlands. } \\
\text { (see Chapter 5) }\end{array}$ & $\begin{array}{l}\text { Municipality of } E l \\
\text { Peñón-Bolívar } \\
\text { (Central Region) }\end{array}$ & $\begin{array}{l}123 \text { families } \\
\text { members of the } \\
\text { peasant association } \\
\text { ASOCAB }\end{array}$ & $\begin{array}{l}\text { El Labrador Consortium: } \\
\text { Aportes San Isidro and } \\
\text { C.I Tequendama (DAABON } \\
\text { group) }\end{array}$ & $\begin{array}{l}\text { Corporación } \\
\text { Desarrollo y Paz del } \\
\text { Magdalena Medio - } \\
\text { CDPMM }\end{array}$ & 2007 & $\begin{array}{l}\text { Constitutional Court of } \\
\text { Colombia 2011; Soler } \\
\text { and León, 2009; Vargas } \\
\text { et al., 2010. Interview } \\
\text { with the CPDMM's } \\
\text { coordinator of the land } \\
\text { protection project during } \\
\text { fieldwork in 2010. }\end{array}$ \\
\hline
\end{tabular}


4. Land dispute for 1,500 hectares of the Bellacruz estate dating from the late 1980 s between a wealthy family that appropriated public lands and peasants that requested titling. Peasants had to leave the lands due to displacement through violent acts. When they returned, they tried to continue with the legal procedure for titling. However,

they found that palm oil companies had occupied the land with an oil palm plantation.

5. Land disputes: plots in the middle of palm oil plantations in the

Municipality of San Alberto used by peasants for small-scale subsistence

farming.

(See Chapter 5)

6. Massive establishment of oil palm by different actors in the Municipality of Simití-Bolivar.

Land use changes and alteration of institutions that shaped access to land resulting in loss of land access by small-holding peasants and landless peasants that used public lands for their livelihoods. Environmental damage to marshlands.

\begin{tabular}{|c|c|c|c|c|c|}
\hline $\begin{array}{l}\text { Municipality of } \\
\text { La Gloria-Cesar } \\
\text { (Central Region) }\end{array}$ & $\begin{array}{l}64 \text { families } \\
\text { members of the } \\
\text { peasant association } \\
\text { ASOCOL }\end{array}$ & $\begin{array}{l}\text { Dolce Vista Estate Inc. which } \\
\text { bought the land from the } \\
\text { family involved in the } \\
\text { historical dispute. } \\
\text { The shareholders of the Dolce } \\
\text { Vista Estate Inc are: } \\
\text { - New foreign investors } \\
\text { (Germán Efromovich; US } \\
\text { investment fund) } \\
\text { - National oil palm growers } \\
\text { (Carlos Murgas; Andrés } \\
\text { Londoño and Daniel Peláez) }\end{array}$ & & 2008 & $\begin{array}{l}\text { Verdad Abierta, 2011a, } \\
2011 \mathrm{~b} \text { and 2013a. }\end{array}$ \\
\hline $\begin{array}{l}\text { Municipality of } \\
\text { San Alberto-Cesar } \\
\text { (Central Region) }\end{array}$ & $\begin{array}{l}64 \text { families } \\
\text { members of the } \\
\text { peasant association } \\
\text { ASOPRODAGRO } \\
\text { PC }\end{array}$ & Indupalma & $\begin{array}{l}\text { CDPMM - land } \\
\text { protection project } \\
\text { (legal support for } \\
\text { defence in court). }\end{array}$ & $2003-2004$ & $\begin{array}{l}\text { Juzgado Promiscuo del } \\
\text { Municipio de Aguachica- } \\
\text { Cesar, 2010. (Lower } \\
\text { Court). } \\
\text { Interviews and group } \\
\text { meetings during } \\
\text { fieldwork in 2011. } \\
\text { Beltrán Ramírez, } 2008\end{array}$ \\
\hline $\begin{array}{l}\text { Municipality of } \\
\text { Simiti-Bolivar. } \\
\text { (Central Region) }\end{array}$ & $\begin{array}{l}\text { Small-holding } \\
\text { peasants, landless } \\
\text { peasants }\end{array}$ & $\begin{array}{l}\text { - Agricolombia (Foreign } \\
\text { investors) } \\
\text { - Compañia Palmera Simití } \\
\text { (Public-private alliance: local } \\
\text { people with land, public funds } \\
\text { from INCUAGRO, and the } \\
\text { national private investors } \\
\text { Asopalma and Walkirias s.a. } \\
\text { - Palmas del Sur } \\
\text { (Public-private alliance: local } \\
\text { small- and medium- scale oil } \\
\text { palm growers; public funds } \\
\text { from the municipality; private } \\
\text { capital from Copalcol Ltda.) }\end{array}$ & & 2000 & Álvarez, 2009 \\
\hline
\end{tabular}


7. Afro-Colombian territories of Alto

Mira and Frontera.

Land dispute. Palm oil company

illegally occupied land belonging to the

collective territories of the Afro-

Colombian communities. Occupation

by palm oil company started in 1998

but a legal decision was made in 2006

declaring the occupation as illegal and

recognizing the Afro-Colombian

communities's right to the land.

8. Massive establishment of oil palm.

Municipality of Zona Bananera-

Magdalena.

Appropriation of land left by local

people due to forced displacement.

Further displacement of local

population due to: 1) food insecurity and lower employment opportunities associated with the transition from

banana to oil palm cultivation, and 2 loss of access to land because of land acquisition by businessmen, companies and paramilitaries for palm oil cultivation.

9. Guapi Abajo palm oil project

Disputes about the ecological,

economic and social effects of a project

for the cultivation of oil palm in 15,000

hectares belonging to the collective

territory of the Afro-Colombian

community of Guapi Abajo.

\begin{tabular}{|c|c|c|c|c|c|}
\hline $\begin{array}{l}\text { Municipality of } \\
\text { Tumaco-Nariño } \\
\text { (South-west } \\
\text { Region) }\end{array}$ & $\begin{array}{l}\text { Afro-Colombian } \\
\text { communities }\end{array}$ & Palmeiras s.a. & $\begin{array}{l}\text { - Proceso de } \\
\text { Comunidades Negras } \\
\text { (PCN) } \\
\text { - Defensoría del } \\
\text { Pueblo (National } \\
\text { Ombudsman Office) }\end{array}$ & $\begin{array}{l}\text { Displacement } \\
\text { started in } 1996 \\
\text { (around } 100 \\
\text { persons), but it } \\
\text { reached its peak in } \\
2000 \text { (around } \\
8,500 \text { persons). } \\
\text { Six companies } \\
\text { started to plant oil } \\
\text { palm in the area } \\
\text { around year } 2000 .\end{array}$ & $\begin{array}{l}\text { Defensoría del Pueblo, } \\
2010 \text {; } \\
\text { Fiscalía General de la } \\
\text { Nación, } 2010 . \\
\text { Interview with officer } \\
\text { from the Office of the } \\
\text { Ombudsman during } \\
\text { fieldwork in } 2010 .\end{array}$ \\
\hline $\begin{array}{l}\text { Municipality of } \\
\text { Zona Bananera- } \\
\text { Magdalena (North } \\
\text { Region) }\end{array}$ & $\begin{array}{l}\text { Small-holding } \\
\text { peasants, landless } \\
\text { peasants, former } \\
\text { employees of } \\
\text { banana plantations }\end{array}$ & $\begin{array}{l}\text { Former large-scale producers } \\
\text { of banana. Established large- } \\
\text { scale palm oil producers and } \\
\text { growers. New comers } \\
\text { interested in oil palm } \\
\text { cultivation. } \\
\text { Paramilitary groups }\end{array}$ & & 2003 & Goebertus, 2008 \\
\hline $\begin{array}{l}\text { Municipality of } \\
\text { Guapi-Cauca } \\
\text { (South-west } \\
\text { Region) }\end{array}$ & $\begin{array}{l}\text { Afro-Colombian } \\
\text { communities of } \\
\text { collective territories } \\
\text { other than Guapi } \\
\text { Abajo. }\end{array}$ & $\begin{array}{l}\text { National government, local } \\
\text { government and the Afro- } \\
\text { Colombian community of } \\
\text { Guapi Abajo. }\end{array}$ & $\begin{array}{l}\text { - COCOCAUCA } \\
\text { (regional } \\
\text { organization } \\
\text { grouping } 9 \text { Afro- } \\
\text { Colombian } \\
\text { communities from } \\
\text { the Cauca province) } \\
\text { - Proceso de } \\
\text { Comunidades Negras } \\
\text { (PCN) } \\
\text { - Vicariato de Guapi }\end{array}$ & 2007 & $\begin{array}{l}\text { IAvH, 2008; Carvajal, } \\
\text { 2010; Alfonso et al., } 2011\end{array}$ \\
\hline
\end{tabular}


10. El Agrado1, 2, 3 estates.

Municipality of Mapiripán-Meta

The lands of El Agrado1, 2, 3 estates

amount to 4,300 hectares of public

lands (that could be assigned to

peasants) that were used by local

people. After massive forced

displacement of local population

occurred at the end of 1990s, Illegal

paramilitary groups unlawfully

appropriated the lands through

fraudulent means in order to establish

oil palm plantations.

11. El Secreto 1, 2, 3 estates.

Municipality of Mapiripán-Meta

The lands of El Secreto 1, 2, 3 estates

amount to 4,655 hectares accumulated

by an oil palm grower to establish oil

palm plantations (under investigation

for unlawful accumulation of land).

\begin{tabular}{l|l} 
Cases of & 12. Palmeras estate.
\end{tabular}

concentration 210 hectares

of land by oil accumulated

palm growing

companies

(under

investigation

for unlawful

accumulation

of land).

\section{Poligrow palm oi}

project. 5,577 hectare

accumulated

14. Bioagroindustrial

de Colombia Ltda

1,040 hectares

accumulated

15. Inversiones Palma

Oriente

526 hectares

accumulated

16. Ecopalma s.a.s

65 hectares

accumulated

\begin{tabular}{|c|c|c|c|c|}
\hline $\begin{array}{l}\text { Municipality of } \\
\text { Mapiripán-Meta } \\
\text { (East Region) }\end{array}$ & $\begin{array}{l}\text { Undetermined } \\
\text { displaced people }\end{array}$ & $\begin{array}{l}\text { Illegal paramilitary groups } \\
\text { (Bloque Centauros) }\end{array}$ & 2007 & Verdad Abierta, 2012 \\
\hline $\begin{array}{l}\text { Municipality of } \\
\text { Mapiripán-Meta } \\
\text { (East Region) }\end{array}$ & $\begin{array}{l}\text { Undetermined } \\
\text { displaced people }\end{array}$ & $\begin{array}{l}\text { Sociedad Villa Diana } \\
\text { (owned by a national palm oil } \\
\text { grower. Eduard Mattos } \\
\text { Barrero) }\end{array}$ & 2007 & $\begin{array}{l}\text { Verdad Abierta, 2012; } \\
\text { MADR, } 2013 .\end{array}$ \\
\hline $\begin{array}{l}\text { Municipality San } \\
\text { Juan de Arama- } \\
\text { Meta (East } \\
\text { Region) }\end{array}$ & $\begin{array}{l}\text { Undetermined } \\
\text { displaced people }\end{array}$ & Palmavista & $2008-2009$ & \multirow[t]{5}{*}{$\begin{array}{l}\text { MADR, 2013; Verdad } \\
\text { Abierta, 2013b. }\end{array}$} \\
\hline $\begin{array}{l}\text { Municipality } \\
\text { Mapiripán-Meta } \\
\text { (East Region) }\end{array}$ & $\begin{array}{l}\text { Undetermined } \\
\text { displaced people }\end{array}$ & Poligrow & $2008-2009$ & \\
\hline $\begin{array}{l}\text { Municipality of } \\
\text { Tibú-Norte de } \\
\text { Santander } \\
\text { (Central Region) }\end{array}$ & $\begin{array}{l}\text { Undetermined } \\
\text { displaced people }\end{array}$ & $\begin{array}{l}\text { Bioagroindustrial de } \\
\text { Colombia Ltda }\end{array}$ & $\begin{array}{l}2001,2008, \\
2009\end{array}$ & \\
\hline $\begin{array}{l}\text { Tibú-Norte de } \\
\text { Santander } \\
\text { (Central Region) }\end{array}$ & $\begin{array}{l}\text { Undetermined } \\
\text { displaced people }\end{array}$ & Inversiones Palma Oriente & 2009 & \\
\hline $\begin{array}{l}\text { Tibú-Norte de } \\
\text { Santander } \\
\text { (Central Region) }\end{array}$ & $\begin{array}{l}\text { Undetermined } \\
\text { displaced people }\end{array}$ & Ecopalma s.a.s & 2010 & \\
\hline
\end{tabular}




\section{Appendix C}

\section{Details of the palm oil agro-industry 'privileged access to the government'}

Table C.1. Details of the flow of individuals moving to work from government to Fedepalma and vice versa.

\begin{tabular}{|c|c|c|c|c|c|c|}
\hline \multirow{2}{*}{$\overbrace{\text { Individuals }}^{\text {Organizations }}$} & \multicolumn{2}{|c|}{ Palm oil sector } & \multicolumn{4}{|c|}{ Government } \\
\hline & Fedepalma & Cenipalma & DNP & MADR & MAVDT & Other \\
\hline A (Arturo Infante Villareal) & \begin{tabular}{|l} 
Consultant* \\
(2004)
\end{tabular} & $\begin{array}{l}\text { President of Board of } \\
\text { Directors Cenipalma } \\
2007 \\
\text { Member board of } \\
\text { directors Cenipalma } \\
\text { (2011-2013) } \\
\end{array}$ & $\begin{array}{l}\text { National Coordinator of } \\
\text { sustainable biofuels development } \\
(2007-2008)\end{array}$ & & & $\begin{array}{l}\text { Ambassador in } \\
\text { Malaysia } \\
(1996-2002)\end{array}$ \\
\hline B (Ricardo Torres Carrasco) & $\begin{array}{l}\text { Director of Planning } \\
\text { and Development } \\
\text { (June 2011-present) }\end{array}$ & & $\begin{array}{l}\text { Director sustainable rural development } \\
\text { (No data-2011) }\end{array}$ & & & \\
\hline C (Juan Carlos Espinosa Camacho) & $\begin{array}{l}\text { Environmental } \\
\text { Director } \\
(2011 \text {-present) }\end{array}$ & & $\begin{array}{l}\text { Worked as a professional in the Environmental } \\
\text { Policy Direction } \\
(2001)\end{array}$ & & & \\
\hline D (Ricardo Sánchez López) & $\begin{array}{l}\text { Economic Director } \\
\text { (before 2002) }\end{array}$ & & Consultant & $\begin{array}{l}\text { Agricultural Policy } \\
\text { Director } \\
(2002-2004) \\
\text { Vice-Minister } \\
(2010-2012)\end{array}$ & & \\
\hline D (Miguel Mazorra Valderrama) & $\begin{array}{l}\text { Environmental } \\
\text { Director } \\
(2000-2011) \\
\end{array}$ & & & & $1995-1999$ & \\
\hline E (Juan Felipe Quintero Villa) & $\begin{array}{l}\text { Economic planning } \\
\text { leader } \\
(2011-2012)\end{array}$ & & & $\begin{array}{l}\text { Advisor vice- } \\
\text { minister } \\
(2006-2008)\end{array}$ & & \\
\hline
\end{tabular}

* Coordinator of a study commissioned by Fedepalma about the technical and economic feasibility of crude palm oil-based biodiesel in Colombia. (Estudio sobre la Prefactibilidad Técnica y Económica de la Producción en Colombia de los Derivados del Aceite Crudo de Palma como Carburantes para Motores de Ciclo Diesel). 
Table C.2. Families, individuals and organizations in the palm oil agro-industry connected with the government and beneficiaries from governmental support

\begin{tabular}{|c|c|c|c|c|c|c|c|c|c|}
\hline \multicolumn{2}{|c|}{$\begin{array}{c}\text { Families/individuals/organizations in } \\
\text { the palm oil agro-industry }\end{array}$} & \multirow{4}{*}{$\begin{array}{c}\text { Personal/family ties } \\
\text { with the government } \\
\text { (all during Álvaro } \\
\text { Uribe } \\
\text { Vélez's government } \\
\text { except Carlos Murgas) }\end{array}$} & \multicolumn{3}{|c|}{$\begin{array}{l}\text { Political support to the government } \\
\text { (economic support or advisory roles) }\end{array}$} & \multicolumn{4}{|c|}{ Benefits received during Álvaro Uribe Vélez's government } \\
\hline \multirow[t]{3}{*}{ Name } & \multirow{3}{*}{$\begin{array}{c}\text { Relation with palm } \\
\text { oil agro-industry }\end{array}$} & & \multirow{3}{*}{$\begin{array}{l}\text { Presidential } \\
\text { campaign } \\
\text { Álvaro Uribe } \\
\text { Vélez } 2002\end{array}$} & \multirow{3}{*}{$\begin{array}{l}\text { Presidential } \\
\text { campaign } \\
\text { Álvaro Uribe } \\
\text { Vélez } 2006\end{array}$} & \multirow{3}{*}{$\begin{array}{c}\text { Campaign } \\
\text { referendum } \\
\text { 2nd } \\
\text { reelection } \\
\text { Álvaro Uribe } \\
\text { Vélez }\end{array}$} & \multicolumn{3}{|c|}{ Direct } & \multirow{3}{*}{$\begin{array}{c}\text { Credit/ } \\
\text { Subsidies for } \\
\text { 'Productive } \\
\text { alliances' } \\
\text { connected } \\
\text { with them. }\end{array}$} \\
\hline & & & & & & \multirow{2}{*}{$\begin{array}{c}\text { Subsidies under } \\
\text { AIS programme } \\
\text { (2007-2009) }\end{array}$} & \multicolumn{2}{|c|}{ Others } & \\
\hline & & & & & & & $\begin{array}{c}\text { Subsidies } \\
2002-2007\end{array}$ & $\begin{array}{l}\text { Tax Free } \\
\text { Zone }\end{array}$ & \\
\hline $\begin{array}{l}\text { Family Murgas } \\
\text { Dávila } \\
\text { (Oleoflores } \\
\text { business group) }\end{array}$ & $\begin{array}{l}\text { Oleoflores s.a. } \\
\text { Dolce Vista Estate } \\
\text { Inc. }\end{array}$ & $\begin{array}{l}\text { Carlos Murgas was } \\
\text { Ministry of Agriculture } \\
\text { 1998-1999 }\end{array}$ & $\begin{array}{l}\text { Contribution } \\
\text { by Oleoflores } \\
\text { Ltda. }\end{array}$ & & $\begin{array}{l}\text { Contribution } \\
\text { by Oleoflores } \\
\text { s.a. }\end{array}$ & $\begin{array}{l}\text { ICR (Murgas } \\
\text { Dávila y } \\
\text { Compañía s en c) } \\
\text { LEC (Extractora } \\
\text { Maria la Baja) }\end{array}$ & $\begin{array}{l}\text { ERC in } 2006 \\
\text { Oleoflores }\end{array}$ & $\begin{array}{l}\text { Oleflores } \\
\text { (biodiesel } \\
\text { refinery) }\end{array}$ & $\begin{array}{l}\text { Credits and } \\
\text { subsidies for } \\
\text { 'productive } \\
\text { alliances' } \\
\text { linked to } \\
\text { Oleoflores }\end{array}$ \\
\hline $\begin{array}{l}\text { Family Dávila } \\
\text { Abondano } \\
\text { (DAABON } \\
\text { business group) }\end{array}$ & $\begin{array}{l}\text { C.I Tequendama } \\
\text { Biocombustibles } \\
\text { Sostenibles del } \\
\text { Caribe s.a. }\end{array}$ & $\begin{array}{l}\text { Sergio Díaz-Granados } \\
\text { (nephew of Carmen } \\
\text { Abondano) was vice- } \\
\text { minister for business } \\
\text { development at the } \\
\text { Ministry of Industry, } \\
\text { Trade and Tourism } \\
\text { between 2006-2008. }\end{array}$ & $\begin{array}{l}\text { Contribution } \\
\text { by Alberto } \\
\text { Dávila } \\
\text { Diazgranados } \\
\text { (father) }\end{array}$ & & $\begin{array}{l}\text { Contribution } \\
\text { by } \\
\text { C.I. } \\
\text { Tequendama } \\
\text { and } \\
\text { C.I La Samaria }\end{array}$ & $\begin{array}{l}\text { Subsidies I\&D } \\
\text { (C.I Tequendama; } \\
\text { C.I La Samaria; } \\
\text { two members of } \\
\text { family and } \\
\text { employees) } \\
\text { Subsidy ERC in } \\
\text { 2008 (C.I. La } \\
\text { Samaria) }\end{array}$ & $\begin{array}{l}\text { ERC In } 2006 \\
\text { (C.I } \\
\text { Tequendama), } \\
\text { ERC in } 2007 \\
\text { (C.I } \\
\text { Tequendama, } \\
\text { C.I La } \\
\text { Samaria), }\end{array}$ & $\begin{array}{l}\text { Bicombusti } \\
\text { bles } \\
\text { Sostenibles } \\
\text { del Caribe } \\
\text { (biodiesel } \\
\text { refinery) }\end{array}$ & $\begin{array}{l}\text { Credits and } \\
\text { subsidies for } \\
\text { 'productive } \\
\text { alliances' } \\
\text { linked to C.I } \\
\text { Tequendama }\end{array}$ \\
\hline $\begin{array}{l}\text { Family Eder } \\
\text { (Manuelita } \\
\text { business group) }\end{array}$ & $\begin{array}{l}\text { Aceites Manuelita } \\
\text { s.a }\end{array}$ & $\begin{array}{l}\text { Alejandro Eder } \\
\text { Director of the } \\
\text { Cooperation and } \\
\text { International Relations } \\
\text { Unit at the Office of the } \\
\text { High Presidential } \\
\text { Commissioner for Peace } \\
\text { and Reintegration 2007- } \\
2010\end{array}$ & $\begin{array}{l}\text { Contribution } \\
\text { by Manuelita } \\
\text { s.a and Sandra } \\
\text { Giovanelly } \\
\text { Eder }\end{array}$ & $\begin{array}{l}\text { Contribution } \\
\text { by Henry } \\
\text { James Eder } \\
\text { Caicedo }\end{array}$ & $\begin{array}{l}\text { Contribution } \\
\text { by Manuelita } \\
\text { s.a }\end{array}$ & $\begin{array}{l}\text { Subsidy ERC in } \\
2008 \text { (Aceites } \\
\text { Manuelita) }\end{array}$ & $\begin{array}{l}\text { Subsidy ERC } \\
\text { in } 2006 \text { and } \\
2007 \text { (Aceites } \\
\text { Manuelita) }\end{array}$ & & \\
\hline
\end{tabular}




\begin{tabular}{|c|c|c|c|c|c|c|c|c|c|}
\hline $\begin{array}{l}\text { Family Gutt-Haime } \\
\text { (Indupalma) }\end{array}$ & Indupalma & & $\begin{array}{l}\text { Contribution } \\
\text { by Detergentes } \\
\text { s.a. }\end{array}$ & $\begin{array}{l}\text { Contribution } \\
\text { by } \\
\text { Carlos Haime } \\
\text { Daniel Haime }\end{array}$ & & & & $\begin{array}{l}\text { Palm oil } \\
\text { extraction } \\
\text { plant } \text { Oro } \\
\text { Rojo }\end{array}$ & $\begin{array}{l}\text { Credits and } \\
\text { subsidies for } \\
\text { Indupalma's } \\
\text { 'productive } \\
\text { alliances' }\end{array}$ \\
\hline $\begin{array}{l}\text { Family Lacouture } \\
\text { Pinedo }\end{array}$ & $\begin{array}{l}\text { C.I El Roble } \\
\text { (Changed name to } \\
\text { Extractora el Roble } \\
\text { s.a.s) } \\
\text { C.I Biocosta s.a }\end{array}$ & $\begin{array}{l}\text { Maria Claudia Lacouture } \\
\text { (daughter) was the } \\
\text { director of the } \\
\text { governmental campaign } \\
\text { 'Colombia es Pasion' at } \\
\text { Proexport governmental } \\
\text { agency 2008-2010 }\end{array}$ & $\begin{array}{l}\text { Contribution } \\
\text { Alfredo } \\
\text { Lacouture } \\
\text { Dangond } \\
\text { (father) }\end{array}$ & & & $\begin{array}{l}\text { Subsidies I\&D for } \\
\text { several members } \\
\text { of the family and } \\
\text { companies (C.I El } \\
\text { Roble and C.I } \\
\text { Palomino) }\end{array}$ & $\begin{array}{l}\text { Subsidy ERC } \\
\text { in } 2007 \text { (C.I El } \\
\text { Roble }\end{array}$ & & $\begin{array}{l}\text { Credits and } \\
\text { subsidies for } \\
\text { 'productive } \\
\text { alliances' } \\
\text { linked to C.I } \\
\text { El Roble }\end{array}$ \\
\hline $\begin{array}{l}\text { Family Vives } \\
\text { Lacouture }\end{array}$ & $\begin{array}{l}\text { Extractora Frupalma } \\
\text { s.a. } \\
\text { C.I Biocosta s.a }\end{array}$ & & $\begin{array}{l}\text { Contribution } \\
\text { by Frupalma } \\
\text { s.a. }\end{array}$ & & & $\begin{array}{l}\text { Subsidies I\&D for } \\
\text { several members } \\
\text { of the family and } \\
\text { companies (C.I } \\
\text { Palomino, Almaja } \\
\text { s.a.) } \\
\text { Subsidy ERC in } \\
2008 \text { (Almaja s.a. } \\
\text { and Frupalma) in } \\
2009 \text { (Almaja) }\end{array}$ & $\begin{array}{l}\text { Subsidy ERC } \\
\text { in } 2006 \\
\text { (Frupalma) } \\
\text { Subsidy ERC } \\
\text { in } 2007 \\
\text { (Frupalma and } \\
\text { Almaja) }\end{array}$ & & $\begin{array}{l}\text { Credits and } \\
\text { subsidies for } \\
\text { 'productive } \\
\text { alliances' } \\
\text { linked to } \\
\text { Frupalma }\end{array}$ \\
\hline $\begin{array}{l}\text { Family Solano } \\
\text { Tribín }\end{array}$ & Inagro s.a & & & & $\begin{array}{l}\text { Contribution } \\
\text { by Nicolás } \\
\text { Simón Solano } \\
\text { Tribín }\end{array}$ & $\begin{array}{l}\text { Subsidies I\&D for } \\
\text { several members } \\
\text { of the family } \\
\text { Inagro s.a }\end{array}$ & & & \\
\hline $\begin{array}{l}\text { Family Mattos } \\
\text { Liñán }\end{array}$ & $\begin{array}{l}\text { Palmagro s.a } \\
\text { C.I Biocosta s.a }\end{array}$ & & $\begin{array}{l}\text { Contribution } \\
\text { by Palmeras } \\
\text { Alamosa s.a } \\
\text { (currently } \\
\text { Palmagro s.a) } \\
\end{array}$ & & & $\begin{array}{l}\text { LEC } \\
\text { Carlos Enrique } \\
\text { Mattos Liñan }\end{array}$ & & & \\
\hline $\begin{array}{l}\text { Family Dangond } \\
\text { Lacouture }\end{array}$ & $\begin{array}{l}\text { Palmas Oleaginosas } \\
\text { de Cascara Ltda }\end{array}$ & & $\begin{array}{l}\text { Contribution } \\
\text { by Palmas } \\
\text { Oleaginosas de } \\
\text { Cascara Ltda. }\end{array}$ & & & $\begin{array}{l}\text { Subsidies I\&D } \\
\text { (Palmas } \\
\text { Oleaginosas de } \\
\text { Cascara Ltda) }\end{array}$ & $\begin{array}{l}\text { Subsidy ERC } \\
\text { in } 2006 \\
\text { (Palmas } \\
\text { Oleaginosas de } \\
\text { Cascara Ltda.) } \\
\end{array}$ & & \\
\hline
\end{tabular}




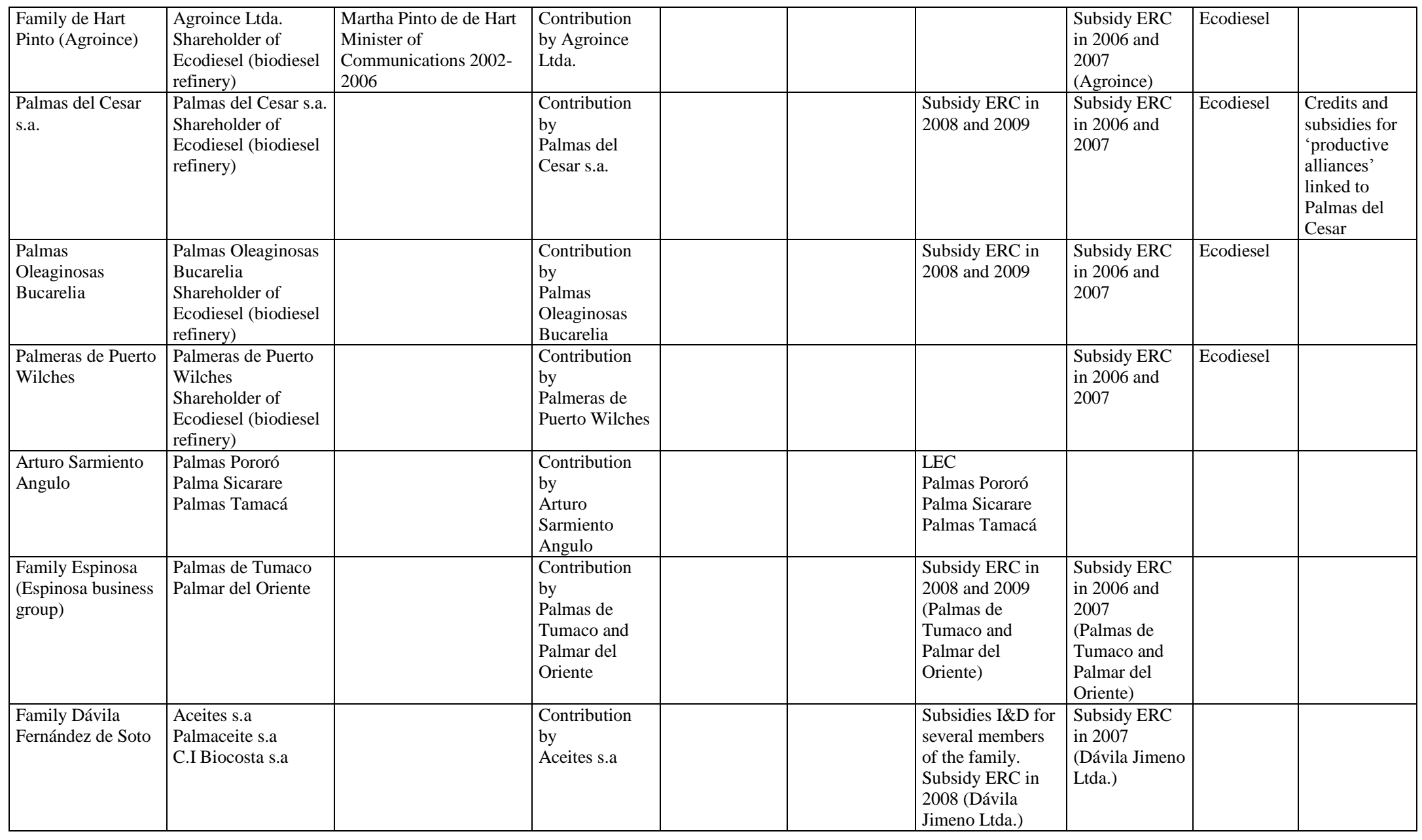




\begin{tabular}{|c|c|c|c|c|c|c|c|}
\hline Guaicaramo s.a. & $\begin{array}{l}\text { Guaicaramo s.a. } \\
\text { Shareholder of Bio } \\
\text { D (biodiesel } \\
\text { refinery) }\end{array}$ & & $\begin{array}{l}\text { Contribution } \\
\text { by } \\
\text { Guaicaramo } \\
\text { s.a. }\end{array}$ & & $\begin{array}{l}\text { Subsidy ERC in } \\
2008 \text { and } 2009\end{array}$ & $\begin{array}{l}\text { Subsidy ERC } \\
\text { in } 2007\end{array}$ & Bio D \\
\hline Palmasol s.a. & $\begin{array}{l}\text { Palmasol s.a. } \\
\text { Shareholder of Bio } \\
\text { D (biodiesel } \\
\text { refinery) }\end{array}$ & & $\begin{array}{l}\text { Contribution } \\
\text { by } \\
\text { Palmasol s.a. }\end{array}$ & & $\begin{array}{l}\text { Subsidy ERC in } \\
2008\end{array}$ & $\begin{array}{l}\text { Subsidy ERC } \\
\text { in } 2007\end{array}$ & Bio D \\
\hline $\begin{array}{l}\text { Agroindustria el } \\
\text { Conuco s.a }\end{array}$ & Oil palm growers & $\begin{array}{l}\text { The shareholders were in } \\
\text { public offices during } \\
\text { Uribe Vélez's } \\
\text { government. Néstor Díaz } \\
\text { Saavedra (Director of } \\
\text { the taxes and customs } \\
\text { agency - DIAN) and } \\
\text { Hernando Carvalho } \\
\text { Quigua (Director of the } \\
\text { Savings National Fund) }\end{array}$ & & & ICR & & \\
\hline $\begin{array}{l}\text { Family } \\
\text { Zúñiga Caballero }\end{array}$ & $\begin{array}{l}\text { Urapalma, Palmura, } \\
\text { Extractora Bajirá, } \\
\text { Gradesa }\end{array}$ & $\begin{array}{l}\text { Maria Fernanda Zúñiga } \\
\text { Chaux was Director of } \\
\text { Fiduagraria } \\
\text { (governmental agency } \\
\text { attached to MADR) } \\
\text { 2006-2008. }\end{array}$ & & & & ICR & \\
\hline $\begin{array}{l}\text { Jens Mesa } \\
\text { Dishington }\end{array}$ & $\begin{array}{l}\text { Executive President } \\
\text { of Fedepalma }\end{array}$ & \begin{tabular}{|l|} 
Maria del Rosario \\
Guerra (the wife of Jens \\
Mesa Dishington) was \\
Director of Colciencias \\
2003-2006. \\
Minister of \\
Communications 2006- \\
2010
\end{tabular} & \begin{tabular}{|l} 
Contribution \\
by Jens Mesa \\
Dishington
\end{tabular} & \begin{tabular}{|l} 
Maria del \\
Rosario Guerra \\
worked in the \\
campaign as \\
advisor
\end{tabular} & & & \\
\hline
\end{tabular}

Sources: CdR, 2010; Constitutional Court of Colombia, 2010b; Coronell, 2009a and 2009b; Franco and Restrepo, 2011; Lewis, 2009a and 2009b; Marín, 2009; MCIT, 2013; Revista Cambio, 2009; Transparencia por Colombia, 2006; Votebien.com, 2006; List of beneficiaries of the AIS programme; Listado de beneficios otorgardos por el Ministerio de Agricultura y Desarrollo Rural - Beneficiarios del Programa de Coberturas. 
Table C.3. Members of families in the palm oil agro-industry connected with the governments of Álvaro Uribe Vélez and Juan Manuel Santos

\begin{tabular}{|c|c|c|c|}
\hline \multicolumn{2}{|c|}{$\begin{array}{c}\text { Families/individuals/organizations in the palm oil agro- } \\
\text { industry }\end{array}$} & \multirow{2}{*}{\begin{tabular}{l}
\multicolumn{1}{c}{$\begin{array}{c}\text { Position in Álvaro Uribe } \\
\text { Vélez's government }\end{array}$} \\
Sergio Díaz-Granados (nephew of Carmen Abondano) was \\
vice-minister for business development at the Ministry of \\
Industry, Trade and Tourism between 2006-2008.
\end{tabular}} & \multirow{2}{*}{\begin{tabular}{|l|} 
Position in Juan Manuel Santos's government \\
$\begin{array}{l}\text { Sergio Díaz-Granados (nephew of Carmen Abondano) } \\
\text { Minister of Industry, Trade and Tourism 2010-2013. }\end{array}$
\end{tabular}} \\
\hline $\begin{array}{l}\text { Family Dávila Abondano } \\
\text { (DAABON business group) }\end{array}$ & $\begin{array}{l}\text { C.I Tequendama } \\
\text { Biocombustibles } \\
\text { Sostenibles del Caribe s.a. }\end{array}$ & & \\
\hline $\begin{array}{l}\text { Family Eder } \\
\text { (Manuelita business group) }\end{array}$ & Aceites Manuelita s.a & $\begin{array}{l}\text { Alejandro Eder } \\
\text { Director of the Cooperation and International Relations Unit } \\
\text { at the Office of the High Presidential Commissioner for } \\
\text { Peace and Reintegration 2007-2010. }\end{array}$ & $\begin{array}{l}\text { Alejandro Eder } \\
\text { High Presidential Commissioner for Social and Economic } \\
\text { Reintegration since } 2010 .\end{array}$ \\
\hline Family Lacouture Pinedo & $\begin{array}{l}\text { C.I El Roble } \\
\text { (Changed name to Extractora } \\
\text { el Roble s.a.s) } \\
\text { C.I Biocosta s.a }\end{array}$ & $\begin{array}{l}\text { Maria Claudia Lacouture (daughter) was the director of the } \\
\text { governmental campaign 'Colombia es Pasion' at Proexport } \\
\text { governamental agency 2008-2010 }\end{array}$ & $\begin{array}{l}\text { Maria Claudia Lacouture (daughter) Director of Proexport } \\
\text { governamental agency since } 2010 \text {. }\end{array}$ \\
\hline Family de Hart Pinto & $\begin{array}{l}\text { Agroince Ltda. Shareholder of } \\
\text { Ecodiesel (biodiesel refinery) }\end{array}$ & $\begin{array}{l}\text { Martha Pinto de de Hart Minister of Communications 2002- } \\
2006\end{array}$ & $\begin{array}{l}\text { Carlos de Hart Pinto } \\
\text { Vice-minister for business development at the Ministry of } \\
\text { Industry, Trade and Tourism since } 2010\end{array}$ \\
\hline
\end{tabular}




\section{References}

Abdullah, R., 2011. World Palm Oil Supply, Demand, Price and Prospects: Focus on Malaysian and Indonesian Palm Oil Industries. Oil Palm Industry Economic Journal 11(2), 13-25.

Adeola, F.O, 2000. Cross-National Environmental Injustice and Human Rights Issues: A Review of Evidence in the Developing World. American Behavioral Scientist 43(4), 686-706.

Aguilera, M.M., 2002. Palma Africana en la Costa Caribe: Un semillero de empresas solidarias. Documentos de Trabajo Sobre Economía Regional, 31. Banco de la República, Cartagena, Colombia.

Alfonso, T., Grueso, L., Prada, M., Salinas, Y., Lemaitre, J., 2011. Derechos enterrados. Comunidades étnicas y campesinas en Colombia, nueve casos de estudio. Ediciones Uniandes, Bogotá, Colombia.

Alonso-Fradejas, A., 2012. Land control-grabbing in Guatemala: the political economy of contemporary agrarian change. Canadian Journal of Development Studies 33(4), 509528.

Álvarez, P., 2008. Una mirada sobre la transformación del campo: el caso de los agrocombustibles en Colombia, in Moncayo, H.L. et al., La cuestión agraria hoy. Colombia: tierra sin campesinos. Instituto Latinoamericano de Servicios Legales Alternativos (ILSA), Bogotá, Colombia, pp. 151-180.

Álvarez, A., 2009. Efectos del monocultivo de la palma de aceite en los medios de vida de las comunidades campesinas. El caso de Simití - Sur de Bolívar. Master thesis. Pontificia Universidad Javeriana, Bogotá, Colombia.

Arts, B., 2006. Non-state actors in global environmental governance - new arrangements beyond the state, in Koenig-Archibugi, M., Zürn, M. (Eds.), New Modes of Governance in the Global System - Exploring Publicness, Delegation and Inclusiveness. Palgrave Macmillan, Hamshire, pp. 177-200.

Auld, G. and L.H. Gulbrandsen, 2010. Transparency in Nonstate Certification: Consequences for Accountability and Legitimacy. Global Environmental Politics 10(3), 97-119.

Avc1, D., Adaman, F., Özkaynak, B., 2010. Valuation languages in environmental conflicts: How stakeholders oppose or support gold mining at Mount Ida, Turkey. Ecological Economics 70(2), 228-238.

Ayodele, T., 2010. African Case Study: Palm Oil and Economic Development in Nigeria and Ghana. Recommendations for the World Bank's 2010 Palm Oil Strategy. Initiative for Public Policy Analysis, Lagos, Nigeria. 
Bäckstrand, K., 2006. Multi-Stakeholder Partnerships for Sustainable Development: Rethinking Legitimacy, Accountability and Effectiveness. European Environment 16(5), 290-306.

Bailey, R., 2008. Another Inconvenient Truth: How biofuel policies are deepening poverty and accelerating climate change. Oxfam International, Oxford.

Barragán, G., 2010. Caso empresarial de negocio inclusivo en palma de aceite y lecciones de mejores prácticas: Alianzas estratégicas productivas y sociales. Palmas 31(2), 161166.

Bebbington, A., 1999. Capital and capabilities: a framework for analising peasants viability, rural livelihoods and poverty. World Development 27(12), 2021-2044.

Bebbington, A. 2004. Livelihood transitions, place transformations: grounding globalization and modernity, in Gwynne, R. and Kay, C. (Eds.), Latin America Transformed. Globalization and Modernity, 2nd edition. Arnold, London, 173-192.

Bebbington, A. (Ed.), 2012a. Social Conflict, Economic Development and Extractive Industry: Evidence from South America. Routledge, London.

Bebbington, A., 2012b. Extractive industries, socio-environmental conflicts and political economic transformations in Andean America, in Bebbington, A. (Ed.), Social Conflict, Economic Development and Extractive Industry: Evidence from South America. Routledge, London, pp. 3-26.

Bebbington, A., 2012c. Underground political ecologies: The second Annual Lecture of the Cultural and Political Ecology Specialty Group of the Association of American Geographers. Geoforum 43(6), 1152-1162.

Bebbington, A., Batterbury, S.P.J., 2001. Transnational Livelihoods and Landscapes: Political Ecologies of Globalization. Ecumene 8(4), 369-380.

Bebbington, A., Humphreys Bebbington, D., Bury, J., Lingan, J., Muñoz, J.P., Scurrah, M., 2008a. Mining and Social Movements: Struggles Over Livelihood and Rural Territorial Development in the Andes. World Development 36(12), 2888-2905.

Bebbington, A., Hinojosa, L., Humphreys Bebbington, D., Burneo, M. L., Warnaars, X., 2008b. Contention and Ambiguity: Mining and the Possibilities of Development. Development and Change 39(6), 887-914.

Bebbington, A., Bury, J. (Eds.), 2013. Subterranean Struggles: New Dynamics of Mining, Oil, and Gas in Latin America. University of Texas Press, Austin.

Beltrán Ramírez, L., 2008. Parceleros de San Alberto. Un conflicto con Indupalma. Corporación Desarrollo y Paz del Magdalena Medio - Proyecto Regional de Tierras, Barrancabermeja, Colombia (unpublished).

Berdal, M., Malone, D. (Eds.), 2000. Greed and grievance: economic agendas in civil wars. Lynne Rienner, Boulder, CO. 
Bermúdez Liévano, A., 2013. El fallo de tutela que tiene al Gobierno con los pelos de punta. La Silla Vacía. Available at: http://lasillavacia.com/historia/el-fallo-de-tutelaque-tiene-al-gobierno-con-los-pelos-de-punta-41515 (Accessed March 23, 2014).

Bernstein, S., 2005. Legitimacy in global environmental governance. Journal of International Law and International Relations 1(1-2), 139-166.

Bernstein, S., 2011. Legitimacy in intergovernmental and non-state global governance, Review of International Political Economy 18(1), 17-51.

Bernstein, S., Cashore, B., 2004. Non-State Global Governance: Is Forest Certification a Legitimate Alternative to a Global Forest Convention?, in Kirton, J., Trebilcock, M. (Eds.), Hard Choices, Soft Law: Combining Trade, Environment, and Social Cohesion in Global Governance, Ashgate, London, pp. 33-63.

Bernstein, S., Cashore, B., 2007. Can non-state global governance be legitimate? An analytical framework. Regulation \& Governance 1, 347-371.

Biermann, F., Gupta, A., 2011. Accountability and legitimacy in earth system governance: A research framework. Ecological Economics 70(11), 1856-1864.

Biersack, A., 2006. Reimagining Political Ecology: Culture/Power/History/Nature, in Biersack, A., Greenberg, J.B. (Eds), Reimagining Political Ecology. Duke University Press, Durham, pp. 3-40.

Blaikie, P., 1985. The political economy of soil erosion in developing countries. Longman, New York.

Blaikie, P., 1999. A Review of Political Ecology. Issues, Epistemology and Analytical Narratives. Zeitschrift für Wirtschaftsgeographie 43(3-4), 131-147.

Blaikie, P., 2012. Should some political ecology be useful? The Inaugural Lecture for the Cultural and Political Ecology Specialty Group, Annual Meeting of the Association of American Geographers, April 2010. Geoforum 43(2), 231-239

Blaikie, P., Brookfield, H., 1987. Land Degradation and Society. Methuen, London.

Borras, S.M., McMichael, P., Scoones, I., 2010. The politics of biofuels, land and agrarian change: editors' introduction. The Journal of Peasant Studies 37(4), 575-592.

Borras, S.M., Franco, J.C., Gómez, S., Kay, C., Spoor, M., 2012. Land grabbing in Latin America and the Caribbean. The Journal of Peasant Studies 39(3-4), 845-872.

Bridge, G., 2004. Mapping the Bonanza: Geographies of Mining Investment in an Era of Neoliberal Reform. The Professional Geographer 56(3), 406-421.

Broegaard, R.B., 2009. Land Access and Titling in Nicaragua. Development and Change 40(1), 149-169.

Bryant, R.L., 1992. Political ecology: An emerging research agenda in Third-World studies. Political Geography 11(1), 12-36.

Bryant, R.L., 1998. Power, knowledge and political ecology in the third world: a review. Progress in Physical Geography 22(1), 79-94.

Bryant, R.L., Bailey, S., 1997. Third World Political Ecology. Routledge, London. 
Buchanan, K.S., 2013. Contested discourses, knowledge, and socio-environmental conflict in Ecuador. Environmental Science \& Policy 30, 19-25.

Burawoy, M., 1998a. The Extended Case Method. Sociological Theory 16(1), 4-33.

Burawoy, M., 2009. The Extended Case Method: Four Countries, Four Decades, Four Great Transformations and One Theoretical Tradition. University of California Press, Berkeley.

Cabra Martínez, J.A., 2011. Avances en el manejo sanitario de la palma de aceite en Colombia: organización, tecnología, aplicación, gestión de recursos. Palmas 32(2), 100-108.

Cárdenas, R., 2012. Green multiculturalism: articulations of ethnic and environmental politics in a Colombian 'black community'. The Journal of Peasant Studies 39(2), 309333.

Carruthers, D. (Ed.), 2008. Environmental Justice in Latin America: Problems, Promise, and Practice. The MIT Press, Cambridge, Massachusetts.

Collier, P., 2000. Economic causes of civil conflict and their implications for policy. World Bank, Washington, DC.

Carvajal, D.V., 2010. El Proyecto Palmero en el Territorio Colectivo de Guapi Abajo: Análisis del choque de intereses y su afectación sobre el Proceso de Toma de Decisiones. Bachelor thesis. Universidad Colegio Mayor de Nuestra Señora del Rosario, Bogotá, Colombia.

Cashore, B., 2002. Legitimacy and the Privatization of Environmental Governance: How Non-State Market-Driven Governance Systems Gain Rule-Making Authority. Governance: an International Journal of Policy, Administration, and Institutions 15(4), 503-529.

Cashore, B., Auld, G., Newsom, D., 2004. Governing Through Markets: Forest Certification and the Emergence of Non-state Authority. Yale University Press, New Haven, CT.

Cashore, B., Egan, E., Auld, G., Newsom, D., 2007. Revising theories of nonstate marketdriven (NSMD) governance: lessons from the Finnish forest certification experience. Global Environmental Politics 7(1), 45-68.

Castañeda-Silva, L., 2011. A forest of evidence: third-party certification and multiple forms of proof - a case study of oil palm plantations in Indonesia. Agriculture and Human Values 29(3), 361-370.

Castells, M., 1999. Grassrooting the space of flows. Urban Geography 20(4), 294-302.

Castiblanco, C., Etter, A., Mitchel Aide, T., 2013. Oil palm plantations in Colombia: a model of future expansion. Environmental Science \& Policy 27, 172-183.

CdR - Consejo de Redacción, 2010. ¿Quiénes financiaron las campañas presidenciales en 2002 y 2006?. CdR, online. Available at: http://www.zoomonline.info/investigacion- 
periodistica/investigaciones-cdr/365-iquienes-financiaron-las-campanas-presidencialesen-2002-y-2006 (Accessed February 5, 2014).

Cecodes - Consejo Empresarial Colombiano para el Desarrollo Sostenible, 2010. Informe Final Evaluación del modelo de Alianzas Productivas en Palma de Aceite. Fedepalma SNV - USAID, Bogotá, Colombia (unpublished).

Cenipalma - Corporación Centro de Investigación en Palma de Aceite, Fedepalma Federación Nacional de Cultivadores de Palma de Aceite, 2009. Agenda Prospectiva de Investigación y Desarrollo Tecnológico para la Cadena Productiva de Palma de Aceite en Colombia con Énfasis en Oleína Roja. Cenipalma - Fedepalma, Bogotá, Colombia.

CGR - Contraloría General de la República, 2006. Análisis de tres instrumentos de política sectorial: el incentivo a la capitalización rural - ICR, el fondo agropecuario de garantías - FAG y el incentivo a la cobertura cambiaria - ICC. Contraloría General de la República, Bogotá, Colombia.

CGR - Contraloría General de la República, 2009. Concentración en la distribución de los apoyos económics sectoriales agropecuarios. Contraloría General de la República, Bogotá, Colombia.

CGR - Contraloría General de la República, 2010. Apoyos económicos en el sector agropecuario colombiano. Contraloría General de la República, Bogotá, Colombia.

Clancy, J., 2013. Biofuels and Rural Poverty. Earthscan, London.

Colchester, M., Jiwan, N., Andiko, Sirait, M., Firdaus, A.Y., Surambo, A., Pane, H., 2006. Promised Land: Palm oil and Land Acquisition in Indonesia - Implications for Local Communities and Indigenous Peoples. Forest Peoples Programme - SawitWatch, Moreton-in-Marsh and Bogor.

Collier, P., Hoeffler, A., 2005. Resource rents, governance and conflict. The Journal of Conflict Resolution 49(4), 625-633.

Comisión Intereclesial de Justicia y Paz, 2007. Palma Aceitera en Colombia: Impactos ambientales socioeconómicos y efectos sobre la tenencia de la tierra, en comunidades campesinas, negras e indígenas. Revista Semillas 30/31. Available at: http://www.semillas.org.co/sitio.shtml?apc=I1----\&x=20154778 (Accessed March 10, 2014).

Conde, M., Kallis, G., 2012. The global uranium rush and its Africa frontier. Effects, reactions and social movements in Namibia. Global Environmental Change 22(3), 596610.

CONPES - Consejo Nacional de Política Económica y Social, 2001. CONPES 3111 Autorización al Gobierno Nacional para Contratar un Crédito Externo con el Banco Mundial por US \$32 Millones para Financiar el Proyecto Alianzas Productivas para la Paz. Departamento Nacional de Planeación, Bogotá, Colombia. 
CONPES - Consejo Nacional de Política Económica y Social, 2003. CONPES 3218 Programa de Desarrollo Alternativo 2003 - 2006. Departamento Nacional de Planeación, Bogotá, Colombia.

CONPES - Consejo Nacional de Política Económica y Social, 2007a. CONPES 3467 Concepto Favorable a la Nación para Contratar un Empréstito Externo con la Banca Multilaterl por un Valor de hasta US \$30 Millones o su Equivalente en otras Monedas, para Financiar Parcialmente el Proyecto "Apoyo a Alianzas Productivas Fase II". Departamento Nacional de Planeación, Bogotá, Colombia.

CONPES - Consejo Nacional de Política Económica y Social, 2007b. CONPES 3477 Estrategia para el Desarrollo Competitivo del Sector Palmero Colombiano. Departamento Nacional de Planeación, Bogotá, Colombia.

CONPES - Consejo Nacional de Política Económica y Social, 2008. CONPES 3510 Lineamientos de Política Para Promover la Producción Sostenible de Biocombustibles en Colombia. Departamento Nacional de Planeación, Bogotá, Colombia.

Constitutional Court of Colombia, 2010a. Auto Mayo 18, 2010.

Constitutional Court of Colombia, 2010b. Sentencia C-141/10.

Constitutional Court of Colombia, 2011. Sentencia T-267, 2011.

CONtextoganadero, 2013. Se crea frente para atacar la Pudrición de Cogollo. CONtextoganadero.com. Available at:

http://contextoganadero.com/agricultura/se-crea-frente-para-atacar-la-pudricion-decogollo (Accessed March 23, 2014).

CONtextoganadero, 2014. Producción de aceite de palma se incrementó 7\% en 2013. CONtextoganadero.com. Available at:

http://www.contextoganadero.com/economia/produccion-de-aceite-de-palma-seincremento-7-en-2013 (Accessed March 23, 2014).

Contreras, M. (Dir.), Figueroa, R. (Prod.). November 12, 2010. La tierra y el territorio. Online video clip. YouTube. Accessed March 15, 2014. https://www.youtube.com/watch?v=L59hqRcRfyU\#t=477.

Cooke, F.M., 2002. Vulnerability, control and oil palm in Sarawak: globalization and a new era?. Development and Change 33(2), 189-211.

Corbera, E., Brown, K., 2010. Offsetting benefits? Analyzing access to forest carbon. Environment and Planning A 42(7), 1739-1761.

Coronado Delgado, S., Dietz, K., 2013. Controlando territorios, reestructurando relaciones socio-ecológicas: La globalización de agrocombustibles y sus efectos locales, el caso de Montes de María en Colombia. Iberoamericana 49, 93-116.

Coronell, D., 2009a. Otras Zonas Francas. Revista Semana, Bogotá, Colombia. Available at: http://www.semana.com/opinion/articulo/otras-zonas-francas/109562-3. (Accessed February 5, 2014). 
Coronell, D., 2009b. El Pastorcito. Revista Semana, Bogotá, Colombia. Available at: http://www.semana.com/opinion/articulo/el-pastorcito/108240-3 (Accessed February 5, 2014).

Correa, H.D., Burgos, P., HEKS, Post Office Cowboys. February 2, 2012. De palmas, puentes y memoria. Un llamado desde El Catatumbo. Online video clip. YouTube. Accessed March 23, 2014. https://www.youtube.com/watch?v=mU6WxYrZfOs.

Corredor Ríos, A., 2008. Competitividad de costos de la agroindustria de la palma de aceite en Colombia. Presentation at the meeting of the National Federation of Oil Palm Growers-Fedepalma held in Villavicencio-Colombia on November 14, 2008. Available at: http://portal.fedepalma.org//discursos.htm (Accessed June 12, 2013).

Cramb, R.A., Curry, G.N. (Eds.), 2012. Special Issue: Oil Palm and Rural Livelihoods in the Asia-Pacific Region. Asia Pacific Viewpoint 53(3), 223-342.

Curry, G.N., Koczberski G., 2009. Finding common ground: Relational concepts of land tenure and economy in the oil palm frontier of Papua New Guinea. The Geographical Journal 175(2), 98-111.

Dangond, I., 2013. La verdad sobre las alianzas. Kienyke.com. Available at: http://www.kienyke.com/kien-escribe/verdad-alianzas-productivas/ (Accessed March 23, 2014).

Dauvergne, P., Neville, K.J., 2010. Forests, food, and fuel in the tropics: the uneven social and ecological consequences of the emerging political economy of biofuels. The Journal of Peasant Studies 37(4), 631-660.

Defensoría del Pueblo, 2005. Resolución Defensorial No 39. Violación de los Derechos Humanos por siembra de Palma africana en territorios colectivos de Jiguamiandó y Curvaradó - Chocó. Bogotá D. C. junio de 2005. Defensoría del Pueblo, Bogotá, Colombia.

Defensoría del Pueblo, 2010. Resolución Defensorial No 59. Vulneración de los derechos a la tierra, al territorio y al medio ambiente de la comunidad de Alto Mira y Frontera Tumaco (Nariño). Bogotá D. C. 29 de diciembre de 2010. Defensoría del Pueblo, Bogotá, Colombia.

Defensoría del Pueblo, 2011. Informe de Seguimiento 2011 a la Sentencia T-025 de 2004. Defensoría del Pueblo, Bogotá, Colombia.

Demaria, F., 2010. Shipbreaking at Alang-Sosiya (India): An ecological distribution conflict. Ecological Economics 70(2), 250-260.

Dion, M.L., Russler C., 2008. Eradication Efforts, the State, Displacement and Poverty: Explaining Coca Cultivation in Colombia during Plan Colombia. Journal of Latin American Studies 40(3), 399-421.

Dobson, A., 1998. Justice and the Environment: Conceptions of Environmental Sustainability and Theories of Distributive Justice. Oxford University Press, Oxford. 
Domhoff, G. W., 2006. Who Rules America? Power, Politics, \& Social Change (5th ed.). McGraw-Hill, New York.

Domhoff, G.W., 2007. C. Wright Mills, Floyd Hunter, and 50 Years of Power Structure Research. Michigan Sociological Review 2, 1-54.

EC - European Commission, 2003. Directive 2003/30/EC of the European Parliament and of the Council of 8 May 2003 on the promotion of the use of biofuels or other renewable fuels for transport. Official Journal of the European Union L123/42-46. European Commission, Brussels.

EC - European Commission, 2009. Directive 2009/28/EC of the European Parliament and of the Council of 23 April 2009 on the promotion of the use of energy from renewable sources amending and subsequently repealing Directives 2001/77/EC and 2003/30/EC. Official Journal of the European Union L140/16-62. European Commission, Brussels.

EC - European Commission, 2010. Commission sets up system for certifying sustainable biofuels. MEMO/10/247, 10 June 2010. European Commission, Brussels,. Available at: http://europa.eu/rapid/pressReleasesAction.do?reference=MEMO/10/247\&format=HT ML\&aged $=0 \&$ language $=E N \&$ guiLanguage $=$ fr $($ Accessed July 4, 2013).

Ecofys, Fraunhofer, BBH, Energy Economics Group - TU Vienna, Winrock International, Fischer, G., 2012. Progress in Renewable Energy and Biofuels Sustainability. European Commission, Brussels.

Eden, S., 2004. The politics of certification: consumer knowledge, power, and global governance in ecolabeling, in Peet, R., Robbins, P., Watts, M. (Eds.), Global Political Ecology. Routledge, New York, pp. 169-184.

Edwards, R., Szekeres, S., Neuwahl, F., Mahieu, V., 2008. Biofuels in the European Context: Facts and Uncertainties (G. de Santi, Ed.). European Commission Joint Research Centre (JRC), Petten, The Netherlands.

El Tiempo, 2007. 'Fiebre' por la palma de aceite desplazó a 4.000 campesinos en el sur de Bolívar. El Tiempo online. Available at:

http://www.eltiempo.com/archivo/documento/CMS-3385535 (Accessed March 19, 2014).

El Tiempo, 2009. Polémica por desalojo de desplazados en sur de Bolívar. El Tiempo online. Available at: http://www.eltiempo.com/archivo/documento/CMS-5642386 (Accessed August 31, 2013).

Elgert, L., 2012. Certified discourse? The politics of developing soy certification standards. Geoforum 43(2), 295-304.

Enlaza, 2009. Caracterización Socio-Ambiental Consorcio El Labrador S.A. Enlaza (unpublished).

Escobar, A., 1998. Whose Knowledge, Whose nature? Biodiversity, Conservation, and the Political Ecology of Social Movements. Journal of Political Ecology 5, 53-82. 
Escobar, A., 2001. Culture sits in places: reflections on globalism and subaltern strategies of localization. Political Geography 20(2), 139-174.

Escobar, A., 2003. Displacement, development, and modernity in the Colombian Pacific. International Social Science Journal 55(175), 157-167.

Escobar, A., 2006a. Difference and Conflict in the Struggle Over Natural Resources: A political ecology framework. Development 49(3), 6-13.

Escobar, A., 2006b. An ecology of difference: Equality and conflict in a glocalized world. Focaal-European Journal of Anthropology 47, 120-137.

Escobar, A., 2008. Territories of Difference: Place, Movements, Life, Redes. Duke University Press, Durham.

Escobar, A., 2010. Postconstructivist political ecologies, in Redclift, M. and Woodgate G. (Eds.), The International Handbook of Environmental Sociology, 2nd edition. Elgar, Cheltenham, pp. 91-105.

EurObserv'ER, 2004. Biofuels Barometer. Systèmes Solaires - le journal des énergies renouvelables 161. Available at: http://www.ieo.pl/en/component/docman/cat_view/54barometry-biopaliwowe.html (Accessed July 4, 2013).

EurObserv'ER, 2005. Biofuels Barometer. Systèmes Solaires - le journal des énergies renouvelables 167. Available at: http://www.ieo.pl/en/component/docman/cat_view/54barometry-biopaliwowe.html (Accessed July 4, 2013).

EurObserv'ER, 2006. Biofuels Barometer. Systèmes Solaires - le journal des énergies renouvelables 173. Available at: http://www.ieo.pl/en/component/docman/cat_view/54barometry-biopaliwowe.html (Accessed July 4, 2013).

EurObserv'ER, 2007. Biofuels Barometer. Systèmes Solaires - le journal des énergies renouvelables 179. Available at: http://www.ieo.pl/en/component/docman/cat_view/54barometry-biopaliwowe.html (Accessed July 4, 2013).

EurObserv'ER, 2008. Biofuels Barometer. Systèmes Solaires - le journal des énergies renouvelables, 185. Available at: http://www.eurobserv-er.org/pdf/baro185.pdf (Accessed July 4, 2013).

EurObserv'ER, 2009. Biofuels Barometer. Systèmes Solaires - le journal des énergies renouvelables, 192. Available at: http://www.eurobserv-er.org/pdf/baro192.pdf (Accessed July 4, 2013).

EurObserv'ER, 2010. Biofuels Barometer. Systèmes Solaires - le journal des énergies renouvelables, 198. Available at: http://www.energies-renouvelables.org/observer/stat_baro/observ/baro198.pdf (Accessed July 4, 2013).

EurObserv'ER, 2011. Biofuels Barometer. Systèmes Solaires - le journal des énergies renouvelables, 204. Available at: http://www.energies-renouvelables.org/observer/stat_baro/observ/biofuels_2011.pdf (Accessed July 4, 2013).

Fadul Ortíz, M., 2001. Informe Alianzas por la Paz: El Modelo Indupalma. Indupalma, Bogotá, Colombia. 
Fairhead, J., Leach, M., Scoones, I., 2012. Green Grabbing: a new appropriation of nature?. The Journal of Peasant Studies 39(2), 237-261.

Fajardo Montaña, D.A., 2009. Territorios de la agricultura colombiana. Departamento de Publicaciones Universidad Externado de Colombia, Bogotá, Colombia.

FAO - Food and Agriculture Organization, 2008. The state of food and agriculture 2008. Biofuels: prospects, risks and opportunities. FAO, Rome.

FAO - Food and Agriculture Organization, 2012. Biofuel co-products as livestock feed Opportunities and challenges, edited by Harinder P.S. Makkar. FAO, Rome.

FAS-USDA - Foreign Agricultural Service of the United States Department of Agriculture, 2010. Database online. Available at: http://www.fas.usda.gov/psdonline/psdQuery.aspx (Query from September 3, 2010).

Fedebiocombustibles - Federación Nacional de Biocombustibles de Colombia, 2011. Cifras Informativas del Sector Biocombustibles - Biodiesel de Palma de Aceite. Available at: http://www.fedebiocombustibles.com/files/Cifras\%20Informativas\%20del\%20Sector\% 20Biocombustibles\%20-\%20BIODIESEL(13).pdf (Accessed July 4, 2013).

Fedepalma - Federación Nacional de Cultivadores de Palma de Aceite, 2001. Geografía Socioeconómica del Cultivo de la Palma de Aceite en Colombia. Fedepalma, Bogotá, Colombia. Available at: http://portal.fedepalma.org/GeoPalma/index.htm. (Accessed July 4, 2013).

Fedepalma - Federación Nacional de Cultivadores de Palma de Aceite, 2005. Statistical yearbook 2005. Fedepalma, Bogotá, Colombia.

Fedepalma - Federación Nacional de Cultivadores de Palma de Aceite, 2008. Statistical yearbook 2008. Fedepalma, Bogotá, Colombia.

Fedepalma - Federación Nacional de Cultivadores de Palma de Aceite, 2009. Statistical yearbook 2009. Fedepalma, Bogotá, Colombia.

Fedepalma - Federación Nacional de Cultivadores de Palma de Aceite, 2010a. Statistical yearbook 2010. Fedepalma, Bogotá, Colombia.

Fedepalma - Federación Nacional de Cultivadores de Palma de Aceite, 2010b. Process for the National Interpretation of the Principles and Criteria of the Roundtable on Sustainable Palm Oil for Colombia. Support Document. Fedepalma, Bogotá, Colombia.

Fedepalma - Federación Nacional de Cultivadores de Palma de Aceite, 2011a. Statistical yearbook 2011. Fedepalma, Bogotá, Colombia.

Fedepalma - Federación Nacional de Cultivadores de Palma de Aceite, 2011b. Guía ambiental de la agroindustria de la palma de aceite en Colombia. Fedepalma, Bogotá, Colombia.

Fedepalma - Federación Nacional de Cultivadores de Palma de Aceite, 2012a. Statistical yearbook 2012. Fedepalma, Bogotá, Colombia.

Fedepalma - Federación Nacional de Cultivadores de Palma de Aceite, 2012b. Informe de Gestión Fedepalma 2012. Fedepalma, Bogotá, Colombia. Available at: 
http://publicaciones.fedepalma.org/index.php/labfedepalma (Accessed March 23, 2014).

Fedepalma - Federación Nacional de Cultivadores de Palma de Aceite, 2013a. Boletín Económico Marzo de 2013. Fedepalma, Bogotá, Colombia. Available at: http://web.fedepalma.org/sites/default/files/files/Balance\%202012\%204Q\%281\%29.pd f, (Accessed November 27, 2013).

Fedepalma - Federación Nacional de Cultivadores de Palma de Aceite, 2013b. Minianuario Estadístico 2013. Fedepalma, Bogotá, Colombia. Available at: http://fedepalma.portalpalmero.com/bigdata/fedepalma/pdf/minianuario_estadistico_20 13.pdf (Accessed March 23, 2014).

Fediol - The EU Oil and Proteinmeal Industry, 2013a. Vegetable Oils - EU production, imports, exports and consumption statistics. Evolution 1980 - 2011. Available at: http://www.fediol.eu/data/1376905903Stat\%20oils\%20evolution.pdf (Accessed July 4, 2013).

Fediol - The EU Oil and Proteinmeal Industry, 2013b. Food, Feed and Fuels: A Deeper Look. Fediol, Brussels. Available at:

http://www.fediol.eu/data/1364981503A\%20deeper\%20look_policy\%20paper_FINAL. pdf (Accessed July 3, 2013).

Finagro, 2008. Sistema de Información Sectorial - Palma. Finagro, Bogotá, Colombia.

Fiscalía General de la Nación, 2009. Bloque Central Bolívar' entrega bienes por 25 mil millones de pesos. Fiscalía General de la Nación, Bogotá, Colombia. Available at: http://www.fiscalia.gov.co/colombia/noticias/bloque-central-bolivar-entrega-bienespor-25-mil-millones-de-pesos/ (Accessed July 25, 2013).

Fiscalía General de la Nación, 2010. Afrodescendientes en busca de la tierra prometida. Revista Huellas 71, 16-17, Bogotá - Colombia.

Fitzgerald, D., 2003. Every Farm a Factory: The Industrial Ideal in American Agriculture.

Yale University Press, New Haven.

Forero-Álvarez, J., 2002. La Economía Campesina Colombiana 1990-2001. Cuadernos Tierra y Justicia No. 2, ILSA - Instituto Latinoamericano de Servicios Legales Alternativos, Bogotá, Colombia.

Forero-Álvarez, J., 2010a. Prólogo, in Forero-Álvarez, J. (Ed.), El campesino colombiano. Entre el protagonismo económico y el desconocimiento de la sociedad. Editorial Javeriana, Bogotá, Colombia, pp. 3-6.

Forero-Álvarez, J., 2010b. Economía campesina, pobreza, tierra y desplazamiento en Colombia, in Forero-Álvarez, J. (Ed.), El campesino colombiano. Entre el protagonismo económico y el desconocimiento de la sociedad. Editorial Javeriana, Bogotá, Colombia, pp. 69-119.

Forero-Álvarez, J., 2013. The Economy of Family Farming Production. Cuadernos de Desarrollo Rural, 10(70), 27-45. 
Forsyth, T., 2008. Political ecology and the epistemology of social justice. Geoforum 39(2), 756-764.

Foucault, M., 1978. The History of Sexuality Volume 1: The Will to Knowledge. Penguin, Harmondsworth.

Foucault, M., 1983. The Subject and Power, in Dreyfus, H., Rabinow, P. (Eds.), Michel Foucault: Beyond Structuralism and Hermeneutics 2nd edition. The University of Chicago Press, Chicago, pp. 208-226.

Franco, V.L., Restrepo, J.D., 2011. Empresarios palmeros, poderes de facto y despojo de tierras en el Bajo Atrato, in Romero, M. (Ed.), La economía de los paramilitares: redes de corrupción, negocios y política. Corporación Nuevo Arco Iris - Random House Mondadori, Bogotá, Colombia, pp. 269-410.

Fraser, N., 1998. Social Justice in the Age of Identity Politics: Redistribution, Recognition, and Participation, in Peterson, G.B. (Ed.), The Tanner Lectures on Human Values, volume. 19. University of Utah Press, Salt Lake City, pp. 1-67.

Friends of the Earth, 2008. Fuelling destruction in Latin America, the real price of the drive for agrofuels. Friends of the Earth International, Amsterdam.

Friends of the Earth, LifeMosaic and Sawit Watch, 2008. Losing Ground: The human rights impacts of oil palm plantation expansion in Indonesia. Friends of the Earth LifeMosaic - Sawit Watch, London, Edinburgh and Bogor.

Fundación Chasquis Comunicación, Fundación Contravía. May 4, 2011. Las Pavas, la hora del retorno. Online video clip. YouTube. Accessed March 15, 2014. https://www.youtube.com/watch?v=NJqXTFD2sFA\#t=1444.

Fundepalma, 2011. Plan de Desarrollo del Proyecto Finca Campesina con Palma. Ocupación Productiva del Territoria en el Magdalena Medio por sur Propios Pobladores 2011-2020. Fundepalma, Bogotá, Colombia (unpublished).

Fundesvic, 2011. Las familias trabajadoras de la palma contamos nuestra historia. Memoria de las víctimas del sur del Cesar. Cartilla No. 1: “...y empezó nuestro sueño”. Fundesvic - Asociación Minga - Sintraproaceites, Bucaramanga, Colombia.

García-López, G.A., Arizpe, N., 2010. Participatory processes in the soy conflicts in Paraguay and Argentina. Ecological Economics 70(2), 196-206.

García Reyes, P., 2011. La Paz Perdida: Territorios colectivos, palma africana y conflicto armado en el Pacífico colombiano. Doctoral thesis. FLACSO, México.

García Romero, H., Calderón Etter, L., 2012. Evaluación de la política de Biocombustibles en Colombia. Fedesarrollo, Bogotá, Colombia. Available at:

http://www.fedesarrollo.org.co/wp-content/uploads/2011/08/Evaluaci\%C3\%B3n-de-lapol\%C3\%ADtica-de-Biocombustibles-en-Colombia.pdf (Accessed May 20, 2013).

Gerasimchuk, I., Koh, P.Y., 2013. The EU Biofuel Policy and Palm Oil: Cutting subsidies or cutting rainforest?. The International Institute for Sustainable Development (IISD), Winnipeg, Canada. 
Gerber, J-F., 2010. A political ecology of industrial tree plantations with special reference to Cameroon and Ecuador. Doctoral thesis, Autonomous University of Barcelona, Barcelona, Spain.

Gerber, J-F., 2011. Conflicts over industrial tree plantations in the South: Who, how and why?. Global Environmental Change 21(1), 165-176.

Gerber, J-F., Veuthey, S., Martínez-Alier, J., 2009. Linking political ecology with ecological economics in tree plantation conflicts in Cameroon and Ecuador. Ecological Economics 68(12), 2885-2889.

Gerber, J-F., Veuthey, S., 2010. Plantations, resistance and the greening of the agrarian question in coastal Ecuador. Journal of Agrarian Change 10(4), 455-481.

Gereffi, G., Korzeniewicz, M., Korzeniewicz, R.P., 1994. Introduction: global commodity Chains, in Gereffi, G., Kozeniewicz, M. (Eds.), Commodity chains and global capitalism. Praeger, Westport, pp. 1-14.

Gleditsch, N.P., 1998. Armed Conflict and the Environment: A Critique of the Literature. Journal of Peace Research 35(3), 381-400.

GMH - Grupo Memoria Histórica, 2013. ¡Basta ya! Colombia: Memorias de guerra y dignidad. Centro Nacional de Memoria Histórica, Bogotá, Colombia.

Goebertus, J., 2009. Palma de aceite y desplazamiento forzado en Zona Bananera: "trayectorias" entre recursos naturales y conflicto. Colombia Internacional 67, 152-175.

Gómez López, A.O., 2010. Palma de aceite y desarrollo local: Implicaciones en un territorio complejo. Master thesis. Universidad de los Andes, Bogotá, Colombia.

Gramsci, A., 1971. Selections from the Prison Notebooks of Antonio Gramsci, edited and translated by Quintin Hoare and Geoffrey Nowell Smith. International Publishers, New York.

Grossman, L.S., 1998. The Political Ecology of Bananas: Contract Farming, Peasants, and Agrarian Change in the Eastern Caribbean. University of North Carolina Press, Chapel Hill.

Guáqueta, A., 2005. Change and Continuity in U.S.-Colombian Relations and the War Against Drugs. Journal of Drug Issues 35(1), 27-56.

Guha, R., Martinez-Alier, J., 1997. Varieties of Environmentalism: Essays North and South. Earthscan, London.

Guha, R., 2000. The Unquiet Woods: Ecological Change and Peasant Resistance in the Himalaya, expanded edition. University of California Press, Berkeley.

Guthman, J., 2007. The Polanyian way? Voluntary food labels as neoliberal governance. Antipode 39(3), 456-478.

Habermas, J., 1987. The theory of communicative action (vol. 2): System and lifeworld. Polity Press, Cambridge.

Hall, D., 2011. Land grabs, land control, and Southeast Asian crop booms. The Journal of Peasant Studies 38(4), 837-857. 
Harvey, D., 2003. The New Imperialism. Oxford University Press, Oxford and New York. Harvey, D., 2007. Neoliberalism as Creative Destruction. The Annals of the American Academy of Political and Social Science, 610(1), 21-44.

Hecht, S.B., Cockburn, A., 1989. The Fate of the Forest: Developers, Destroyers and Defenders of the Amazon. Verso, London.

Herrera, L., 2008. Minagricultura advierte a campesinos de El Retén (Magdalena) de no vender tierras. El Tiempo online. Available at:

http://www.eltiempo.com/archivo/documento/CMS-4157021 (Accesed, August 22, 2013).

Hickey, S., du Toit., A., 2007. Adverse incorporation, social exclusion and chronic poverty. Working Paper No. 81. Chronic Poverty Research Centre, Manchester.

Holifield, R., Porter, M., Walker, G. (Eds.), 2009. Special issue: Spaces of environmental justice. Antipode 41(4).

Homer-Dixon, T.F., 1999. Environment, scarcity and violence. Princeton University Press, Princeton, NJ.

Hopkins, T.K., Wallerstein, I., 1986. Commodity Chains in the World-Economy Prior to 1800. Review 10(1), 157-170.

Hospes, O., 2011. Private law making at the round table on sustainable palm oil, in Van Der Meulen, B. (Ed.), Private Food Law: Governing Food Chains Through Contract Law, Self-regulation, Private Standards, Audits and Certification Schemes. Wageningen Academic Publishers, The Netherlands, pp. 187-202.

Hospes, O., Clancy, J.S., 2011. Unpacking the Discourse of Social Inclusion in Value Chains, in Helmsing, A.H.J. and Vellema, S. (Eds.), Value Chains, Inclusion and Endogenous Development: Contrasting Theories and Realities. Routledge, Abingdon, pp. 23-41.

Houldey, G., 2008. Fuelling Fear: the human cost of biofuels in Colombia. War on Want, London.

Hurtado, M., Hernández-Salazar, G.A., 2010. Perfil local y agroindustria palmera: Explorando el caso de San Alberto y San Martín (Cesar). Cuadernos de Desarrollo Rural 7(65), 127-149.

IADB - Inter-American Development Bank, 2012. GEF (Global Environmental Facility) project document: Mainstreaming biodiversity in palm cropping in Colombia with an ecosystem approach. IADB, Washington,D.C. Available at:

http://www.thegef.org/gef/sites/thegef.org/files/documents/document/2-1412\%20Colombia-webdoc.pdf (Accessed February 5, 2014).

ICHR - Inter-American Court of Human Rights, 2008. Resolution of February 5, 2008.

Medidas Provisionales respecto de la República de Colombia. Asunto Comunidades del Jiguamiandó y del Curvaradó. Inter-American Court of Human Rights, Washington, D.C. 
IAvH - Instituto Alexander von Humboldt, 2008. Evaluación ambiental estratégica de políticas, planes y programas de biocombustibles en Colombia, con énfasis en biodiversidad. Instituto Alexander von Humboldt. Bogotá, Colombia.

Ibanez, M., 2010. Who crops coca and why? The case of Colombian farmers. Discussion Paper 40. Courant Research Centre 'Poverty, Equity and Growth'.

Ibáñez, A.M., Moya, A., 2010. Do Conflicts Create Poverty Traps? Asset Losses and Recovery for Displaced Households in Colombia, in Di Tella, R., Edwards, S., Schargrodsky, E. (Eds.), The Economics of Crime: Lessons for and from Latin America. National Bureau of Economic Research Conference Report. University of Chicago Press, Chicago and London, pp. 137-172.

ICHR - Inter-American Court of Human Rights, 2008. Resolution of February 5, 2008. Medidas Provisionales respecto de la República de Colombia. Asunto Comunidades del Jiguamiandó y del Curvaradó. Inter-American Court of Human Rights, Washington, D.C.

INCODER, 2012a. Incoder identificó 10 predios baldíos de la nación en la hacienda "Las Pavas". Boletín de prensa No. 133. Incoder, Bogotá, Colombia. Available at: http://www.incoder.gov.co/documentos/Boletines\%20septiembre\%202012/1493_Bolet \%C3\%ADn133LasPavasbald\%C3\%ADos270912.pdf (Accessed September 12, 2013).

INCODER, 2012b. Incoder pone punto final al emblématico caso de la hacienda "Las Pavas”. Boletín de prensa No. 156. Incoder, Bogotá, Colombia. Available at: http://www.incoder.gov.co/documentos/Boletines\%20noviembre\%202012/Bolet\%C3\% ADn156DecisiónFinalLasPavas.pdf (Accessed September 12, 2013).

INCODER, 2012c. "Sí hay predios baldíos en la finca Bellacruz": Incoder. Boletín de prensa No. 22. Incoder, Bogotá, Colombia. Available at:

http://www.incoder.gov.co/documentos/398_Boletin_Bellacruz140212.pdf (Accessed March 23, 2014).

Indupalma, 2009. En el 2010 y en Sabana de Torres se abrirá la planta extractora "Oro Rojo". La Siembra No. 2 - Informativo para comunidades vecinas y amigos de la palma y del campo. Indupalma, Bogotá, Colombia, p. 2.

Indupalma, 2010. La reponsabilidad social empresarial en Indupalma. Indupalma, Bogotá, Colombia.

Indupalma, 2011. Informe de Sostenibilidad 2010-2011. Indupalma, Bogotá, Colombia. Available at:

http://www.unglobalcompact.org/system/attachments/15386/original/Informe_Sostenib ilidad_INDUPALMA_webpage.pdf?1337024883 (Accessed September 12, 2013).

Johansson, J., 2012. Challenges to the Legitimacy of Private Forest Governance - the Development of Forest Certification in Sweden. Environmental Policy and Governance 22(6), 424-436. 
Julia, White, B., 2012. Gendered experiences of dispossession: oil palm expansion in a Dayak Hibun community in West Kalimantan. The Journal of Peasant Studies 39(3-4), 995-1016.

Juzgado Promiscuo del Municipio de Aguachica-Cesar, 2010. Court Decision August 23, 2010 on the process Indupalma S.A. Vs Mariela Ayala Espitia. Juzgado Promiscuo del Municipio de Aguachica-Cesar, Aguachica/Cesar, Colombia.

Kallis, G., Gómez-Baggethun, E., Zografos, C., 2013. To value or not to value? That is not the question. Ecological Economics 94, 97-105.

Kalmanovitz, S., López Enciso, E., 2006. La Agricultura Colombiana en el Siglo XX. Fondo de Cultura Económica - Banco de la República, Bogotá, Colombia.

Kienyke, 2011. Habla la pieza clave en caso Las Pavas. Kienyke.com. Available at: http://www.kienyke.com/historias/habla-la-pieza-clave-en-el-caso-de-las-pavas/ (Accessed September 3, 2013).

Klooster, D., 2006. Environmental Certification of Forest in Mexico: the Political Ecology of a Nongovernmental Market Intervention. Annals of the Association of American Geographers 96(3), 541-565.

Klooster, D., 2010. Standardizing sustainable development? The Forest Stewardship Council's plantation policy review as neoliberal environmental governance. Geoforum 41(1), 117-129.

La Silla Vacía, 2010. El caso de Indupalma. La Silla Vacía. Available at: http://www.lasillavacia.com/queridodiario/18539/el-caso-de-indupalma (Accessed September 17, 2013).

Larson, A., Ribot, J.C., 2007. The poverty of forestry policy: double standards on an uneven playing field. Journal of Sustainability Science 2(2), 189-204.

Lastarria-Cornhiel, S., 1998. El Arrendamiento de Tierras en Colombia: Prácticas y Marco Teórico-Histórico. Departamento Nacional de Planeación - Ministerio de Agricultura y Desarrollo Rural - Instituto Interamericano de Cooperación para la Agricultura, Bogotá, Colombia.

Le Billon, P., 2001. The political ecology of war: natural resources and armed conflicts. Political Geography 20(5), 561-584.

Leff, E., 2012. Political Ecology: A Latin America Perspective, in UNESCO-EOLSS Joint Committee (Eds.), Encyclopedia of Life Support Systems (EOLSS) - Encyclopedia of Social Sciences and Humanities - Culture, Civilization and Human Society. UNESCO, Eolss Publishers, Oxford.

Lewis, J.E. 2009a. Estas son las 15 familias que están en boca de todos en el Congreso por los subsidios millonarios de Agro Ingreso Seguro. La Silla Vacía. Available at: http://www.lasillavacia.com/historia/5090. (Accessed March 5, 2011).

Lewis, J.E. 2009b. Estos son los 51 beneficiarios de Agro Ingreso Seguro que aportaron a campañas de Uribe. La Silla Vacía. Available at: 
http://www.lasillavacia.com/historia/5033?page=2 (Accessed March 5, 2011).

Li, T.M., 1996. Images of Community: Discourse and Strategy in Property Relations. Development and Change 27(3), 501-527.

Li, T.M., 2004. Environment, indigeneity and transnationalism, in Peet, R. and Watts, M. (Eds.), Liberation Ecologies: environment, development, social movements, 2nd edition. Routledge, London/New York, pp. 309-337.

Low, N., Gleeson, B., 1998. Justice, Society and Nature: An Exploration of Political Ecology. Routledge, London.

Lund, C., 2009. Recategorizing 'Public' and 'Private' Property in Ghana. Development and Change 40(1), 131-148.

Machado, A., 1998. La Cuestión Agraria en Colombia a Fines del Milenio. El Ancora Editores, Bogotá, Colombia.

Machado, A., 2002. De la estructura agraria al sistema agroindustrial. Universidad Nacional de Colombia, Colección Sede, Bogotá.

Machado, A., 2009. Ensayos para la historia de la política de tierras en Colombia: de la colonia a la creación del Frente Nacional. Universidad Nacional de Colombia, Centro de Investigaciones para el Desarrollo (CID), Bogotá, Colombia.

Machado, A., Salgado, C., Naranjo, S., 2013. Territorios para el desarrollo de las sociedades y economías campesinas, in Garay Salamanca, L.J. et al., Reflexiones sobre la ruralidad y el territorio en Colombia. Problemáticas y retos actuales. Oxfam, Bogotá, Colombia, pp. 275-366.

MADR - Ministerio de Agricultura y Desarrollo Rural, 2010a. Anuario estadístico del sector agropecuario y pesquero 2010. MADR, Bogotá, Colombia.

MADR - Ministerio de Agricultura y Desarrollo Rural, 2010b. Informe de Rendición de Cuentas, Gestión 2002-2010. MADR, Bogotá, Colombia.

MADR - Ministerio de Agricultura y Desarrollo Rural, 2010c. Informe de Gestión de la Dirección de Cadenas Productivas 2002-2010. MADR, Bogotá, Colombia.

MADR - Ministerio de Agricultura y Desarrollo Rural, 2011. Informe de Rendición de Cuentas, Gestión 2010-2011. MADR, Bogotá, Colombia.

MADR - Ministerio de Agricultura y Desarrollo Rural, 2013. Implementación de la Política Integral de Tierras 2010-2013. MADR, Bogotá, Colombia.

MADR, ICA, Fedepalma, 2014. ABC de la pudrición del cogollo (PC). MADR - ICA Fedepalma, Bogotá, Colombia. Available at:

http://www.palmasana.org/sites/default/files/files/Fitosanitario/ABCdela_PC.pdf (Accessed March 23, 2014).

Malins, C., 2013. Vegetable oil markets and the EU biofuel mandate. International Council on Clean Transportation, London.

Marín, L., 2009. Genealogía de la palma en el Gobierno de Alvaro Uribe. La Silla Vacía. Available at: http://lasillavacia.com/historia/192 (Accessed May 31, 2013). 
Marin-Burgos, V., 2013. Acceso a Recursos y Políticas Sectoriales: el caso del acceso a la tierra y los agrocombustibles en Colombia, in Pérez-Rincón, M., Rojas, J., Galvis, R. (Eds.), Sociedad y Ecosistemas: Minería, Megaproyectos y Educación Ambiental. Programa Editorial Universidad del Valle, Cali, Colombia.

Marin-Burgos, V., Forthcoming 2014. Social-environmental conflicts and agrofuel crops: The case of oil palm expansion in Colombia, in Dietz, K., Engels, B., Pye, O., Brunnengräber A. (Eds.), The Political Ecology of Agrofuels. Routledge ISS Studies in Rural Livelihoods. Routledge, London.

Marin-Burgos, V., Clancy, J.S., Lovett, J.C., 2014 (in press). Contesting legitimacy of Voluntary Sustainability Certification Schemes: valuation languages and power asymmetries in the Roundtable on Sustainable Palm Oil in Colombia. Ecological Economics (2014), http://dx.doi.org/10.1016/j.ecolecon.2014.04.011

Martin, A. (Ed.), 2013. Themed Section: Global environmental in/justice, in practice. The Geographical Journal 179(2), 98-149.

Martinez-Alier, J., 2002. The Environmentalism of the Poor: A Study of Ecological Conflicts and Valuation. Edward Elgar, Cheltenham.

Martinez-Alier, J., 2009. Social Metabolism, Ecological Distribution Conflicts, and Languages of Valuation. Capitalism Nature Socialism 20(1), 58-87.

Martinez-Alier, J., 2012. Joan Martinez-Alier interviewed by Lorenzo Pellegrini. Development and Change 43(1), 341-359.

Martinez-Alier, J., 2013 (in press). The environmentalism of the poor. Geoforum (2013), http://dx.doi.org/10.1016/j.geoforum.2013.04.019.

Martinez-Alier, J., Kallis, G., Veuthey, S., Walter, M., Temper, L., 2010. Social Metabolism, Ecological Distribution Conflicts and Valuation Languages. Ecological Economics 70(2), 153-158.

Martinez-Alier J., Anguelovski I., Bond P., Del Bene D., Demaria F., Gerber J.-F., Greyl L., Haas W., Healy H., Marín-Burgos V., Ojo G., Porto M., Rijnhout L., RodríguezLabajos B., Spangenberg J., Temper L., Warlenius R., Yánez, I., 2014. Between activism and science: grassroots concepts for sustainability coined by Environmental Justice Organizations. Journal of Political Ecology 21, 19-60.

Martínez López, G., 2010. Pudrición del cogollo, Marchitez sorpresiva, Anillo rojo y Marchitez letal en la palma de aceite en América. Palmas 31(1), 43-53.

McAfee, K., 1999. Selling nature to save it? Biodiversity and green developmentalism. Environment and Planning D: Society and Space 17(2), 133-154.

McCarthy, J.F., 2010. Processes of inclusion and adverse incorporation: oil palm and agrarian change in Sumatra, Indonesia. The Journal of Peasant Studies 37(4), 821-850.

McCarthy, J.F., Cramb, R.A., 2009. Policy narratives, landholder engagement, and oil palm expansion on the Malaysian and Indonesian frontiers. The Geographical Journal 175(2), 112-123. 
McDermott, C., 2012. Trust, legitimacy and power in forest certification: A case study of the FSC in British Columbia. Geoforum 43(3), 634-644.

MCIT - Ministerio de Comercio, Industria y Turismo, 2013. Informe de Zonas Francas Aprobadas. MCIT, Bogotá, Colombia. Available at:

https://www.mincomercio.gov.co/minindustria/publicaciones.php?id=168 (Accessed May 31, 2013).

Meertens, D., 1985. La aparcería en Colombia: formas, condiciones e incidencia actual. Cuadernos de Agroindustria y Economía Rural 14/15, 11-62.

Mejía Alfonso, S.L., 2010. La política de agrocombustibles y sus conflictos socioecológicos distributivos en Colombia. Master thesis. Universidad Nacional de Colombia. Bogotá, Colombia.

Mesa Dishington, J., 2009. Lo gremial, pilar del desarrollo palmero. Fedepalma, Bogotá, Colombia.

Mesa Dishington, J., 2011. La palma de aceite: un actor relevante para la reconciliación, los biocombustibles y el desarrollo de la Orinoquía. Presentation at the forum "Reconciliación-Urbanismo-Energía" on August 23, 2011, Bogotá, Colombia.

Available at: http://www.urosario.edu.co/urosario_files/45/45878930-aa4d-4504-b06282c717f14070.pdf (Accessed June 27, 2013).

Mesa Dishington, J., 2013. Fedepalma, un gremio mirando al futuro. Palmas 34(1), 73-77.

Mingorance, F., 2006. The flow of palm oil Colombia - Belgium/Europe. A study from a human rights perspective. Human Rights Everywhere (HREV) - Coordination Belge pours la Colombie, Brussels. Available at http://cbc.collectifs.net/doc/informe_en_v31.pdf (Accessed April 18, 2011).

Molano Bravo, A., 2004. Coca, Land and Corruption, in Baud, M., Meertens, D. (Eds.), Colombia from the Inside: Perspectives on Drugs, War and Peace. CEDLA, Amsterdam, pp. 65-78.

Molano Bravo, A, 2009a. En medio del Magdalena Medio. Centro de Investigación y Educación Popular (Cinep), Bogotá, Colombia.

Molano Bravo, A., 2009b. Las Pavas, crónica de un desalojo. El Espectador online. Available at: http://www.elespectador.com/impreso/articuloimpreso153956-pavascronica-de-un-desalojo (Accessed August 31, 2013).

Molano Bravo, A., 2012. Paramilitarismo y palma en el Catatumbo. El Espectador online. Available at: http://www.elespectador.com/impreso/judicial/articulo-330074paramilitarismo-y-palma-el-catatumbo (Accessed March 23, 2014).

Monbiot, G., 2005. Worse Than Fossil Fuel. The Guardian, London. Available at: http://www.monbiot.com/2005/12/06/worse-than-fossil-fuel/ (Accessed August 21, 2013) 
Moore, D.S., 1993. Contesting Terrain in Zimbabwe's Eastern Highlands: Political Ecology, Ethnography and Peasant Resource Struggles. Economic Geography 69(4), 380-401.

Moore, J.W., 2000. Sugar and the expansion of the early modern world-economy: Commodity frontiers, ecological transformation, and industrialization. Review 23(3), 409-433.

Mosquera Montoya, M., Gómez Cuervo, P.L., Bernal Hernández, P., 2007. Topics to be Considered for Establishing Competitive Plantations of Oil Palm in Colombia. Palmas 28(3), 37-44.

Mosquera, M., Grogan, K.A., Evans, E.A., Spree, T., 2012. A Dynamic Model of Pudrición del Cogollo Disease (PC) Control in the Colombian Palm Oil Industry. Selected Paper prepared for presentation at the Agricultural \& Applied Economics Association 2012 Annual Meeting, Seattle, Washington on August 12-14, 2012. Available at: http://ageconsearch.umn.edu/bitstream/124785/2/MosqueraEtAlFinal.pdf (Accessed February 26, 2014).

Muradian, R., Martinez-Alier, J., Correa, H., 2003. International Capital Versus Local Population: The Environmental Conflict of the Tambogrande Mining Project, Peru. Society and Natural Resources 16(9), 775-792.

Muradian, R., Walter, M., Martinez-Alier, J., 2012. Hegemonic transitions and global shifts in social metabolism: Implications for resource-rich countries. Introduction to the special section. Global Environmental Change 22(3), 559-567.

Murcia Navarro, A., 2010. Informe de Consultoría. Indupalma, Bogotá, Colombia.

Murgas, C., 1999. Alianzas productivas y sociales para sembrar la paz. Ministerio de Agricultura y Desarrollo Rural, Bogotá, Colombia.

MVO - Product Board for Margarine, Fats and Oils, 2008. Fact Sheet Rapeseed 2008. MVO, Rijswijk, The Netherlands.

MVO - Product Board for Margarine, Fats and Oils, 2009. Market Analysis Oils and Fats for Fuel 2009. MVO, Rijswijk, The Netherlands.

MVO - Product Board for Margarine, Fats and Oils, 2010. Fact Sheet Palm Oil 2010. MVO, Rijswijk, The Netherlands.

Neumann, R.P., 2008. Probing the (in)compatibilities of social theory and policy relevance in Piers Blaikie's political ecology. Geoforum 39(2), 728-735.

Nikoloyuk, J., Bruns, T., de Man, R., 2010. The promise and limitations of partnered governance: the case of sustainable palm oil. Corporate Governance 10(1), 59-72.

Nouwen, S., 2013., 'As You Set Out for Ithaka': Practical, Epistemological, Ethical and Existential Questions About Socio-Legal Empirical Research in Conflict. University of Cambridge Faculty of Law Research Paper No. 43/2013. Available at SSRN: http://ssrn.com/abstract=2341150 or http://dx.doi.org/10.2139/ssrn.2341150 (Accessed March 13, 2014). 
Observatorio Agrocadenas, 2006. Agroindustria y competitividad: Estructura y dinámica en Colombia 1992 - 2005. Ministerio de Agricultura y Desarrollo Rural - IICA, Bogotá, Colombia.

Ocampo Valencia, S., 2009. Agroindustria y conflicto armado. El caso de la palma de aceite. Colombia Internacional 70, 169-190.

OCMAL - Observatorio de Conflictos Mineros de América Latina, 2014. Databse of mining conflicts, projects and corporations in Latin América. Available at: http://basedatos.conflictosmineros.net/ocmal_db (Accessed January 28, 2014).

Oil World, 2001. Oil World Annual 2001. ISTA Melke GmbH, Hamburg, Germany.

Oil World, 2011. Oil World Annual 2011. ISTA Melke GmbH, Hamburg, Germany.

Oleaginosas Las Brisas S.A., 2010. Informe de Sostenibilidad 2009-2010. Oleaginosas Las Brisas S.A, Bucaramanga, Colombia.

Olssen, M., 1999. Michel Foucault: materialism and education. Bergin and Garvey, Westport, CT.

Oosterkamp, J.W., de Bruin, I., Auza, G., 2007. Oil Palm: comparing Chocó (Colombia) with West Kalimantan (Indonesia). Cordaid, Bogotá, Colombia.

Orta-Martínez, M., Finer, M., 2010. Oil frontiers and indigenous resistance in the Peruvian Amazon. Ecological Economics 70(2), 207-218.

Ortíz, C., 2004. Agricultura, Cultivos Ilícitos y Medio Ambiente en Colombia, in Cárdenas M., Rodríguez, M. (Eds.), Guerra, Sociedad y Medio Ambiente. Foro Nacional Ambiental, Bogotá, Colombia, pp. 297-349.

Ospina Bozzi, M.L., 2007. The Faces of Oil Palm. Fedepalma, Bogotá, Colombia.

Overbeek, W., Kröger, M., Gerber, J-F., 2012. An overview of industrial tree plantation conflicts in the global South. Conflicts, trends, and resistance struggles. EJOLT Report No. 3.

Özkaynak, B., Rodriguez-Labajos, B., Arsel, M., Avc1, D., Carbonell, M.H., Chareyron, B., Chicaiza, G., Conde, M., Demaria, F., Finamore, R., Kohrs, B., Krishna, V.V., Mahongnao, M., Raeva, D., Singh, A.A., Slavov, T., Tkalec, T., Yánez, I., Walter, M., Živčič, L., 2012. Mining Conflicts around the World: Common Grounds from Environmental Justice Perspective. EJOLT Report No. 7.

Partzsch, L., 2011. The legitimacy of biofuel certification. Agriculture and Human Values 28(3), 413-425.

Pattberg, P., 2005. The institutionalization of private governance: How business and nonprofits agree on transnational rules. Governance: An International Journal of Policy, Administration, and Institutions 18(4), 589-610.

Pattberg, P., 2006. Private Governance and the South: lessons from global forest politics. Third World Quarterly 27(4), 579-593.

Paulson, S., Gezon, L. (Eds.), 2004. Political Ecology across Spaces Scales and Social Groups. Rutgers University Press, New Brunswick, NJ. 
Peet, R., Watts, M. (Eds.), 1996a. Liberation Ecologies: environment, development, social movements. Routledge, London/New York.

Peet, R., Watts, M., 1996b. Liberation Ecology: Development, sustainability, and environment in an age of market triumphalism, in Peet, R., Watts, M. (Eds.), Liberation Ecologies: environment, development, social movements. Routledge, London/New York, pp. 1-45.

Peet, R., Watts, M. (Eds.), 2004. Liberation Ecologies: environment, development, social movements, 2nd edition. Routledge, London/New York.

Peluso, N.L., 1992a. Rich Forests, Poor People: Resource Control and Resistance in Java. University of California Press, Berkeley.

Peluso, N.L., 1992b. The Political Ecology of Extraction and Extractive Reserves in East Kalimantan, Indonesia. Development and Change 23(4), 49-74.

Peluso, N.L., 2009. Rubber Erasures, Rubber Producing Rights: Making Racialized Territories in West Kalimantan, Indonesia. Development and Change 40(1), 47-80.

Peluso, N.L., Lund. C., 2011. New frontiers of land control: Introduction. The Journal of Peasant Studies 38(4), 667-681.

Peluso, N.L., Watts, M. (Eds.), 2001a. Violent Environments. Cornell University Press, Ithaca and London.

Peluso, N.L., Watts, M., 2001b. Violent Environments, in Peluso, N.L., Watts, M. (Eds.), Violent Environments. Cornell University Press, Ithaca and London, pp. 3-38.

Peña, D.G., 2003. Identity, Place and Communities of Resistance, in Agyeman, J., Bullard, R.D., Evans, B. (Eds.), Just Sustainabilities: Development in an Unequal World. Earthscan - MIT Press, London, pp. 146-167.

Pérez Castro, G., 2012. Corozo en Zona Bananera: Etnografía del Cultivo de Palma Entre Pequeños Productores. Bachelor thesis. Universidad del Magdalena, Santa Marta, Colombia.

Pérez-Rincón, M.A., 2008. Los agrocombustibles: ¿Sólo canto de sirenas?. Análisis de los impactos ambientales y sociales para el caso colombiano, in Vélez, I. (Ed.), Agrocombustibles: Llenando tanques, vaciando territorios. CENSAT Agua Viva Proceso de Comunidades Negras, Bogotá, Colombia, pp. 81-116.

Pesqueira, L., Glasbergen, P., 2012 Playing the politics of scale: Oxfam's intervention in the Roundtable on Sustainable Palm Oil. Geoforum 45, 296-304.

Ploeg, J.D. van der, 2008. The new peasantries: struggles for autonomy and sustainability in an era of empire and globalization. Earthscan, London.

PNUD - Programa de las Naciones Unidas para el Desarrollo, 2011. Informe Nacional de Desarrollo Humano 2011: Colombia rural. Razones para la esperanza. PNUD, Bogotá, Colombia.

Ponte, S., 2012. The Marine Stewardship Council (MSC) and the Making of a Market for 'Sustainable Fish'. Journal of Agrarian Change 12(2,3), 300-315. 
Presidencia de la República, 2010. Campesinos de Bolívar reciben 1.600 hectáreas de tierras que alias 'Macaco' había arrebatado a sus dueños. Presidencia de la República, Bogotá, Colombia. Available at:

http://wsp.presidencia.gov.co/Prensa/2010/Septiembre/Paginas/20100903_13.aspx

(Accessed July 25, 2013).

Prieto Méndez, A., 2008. Informe el Modelo de Gestión de Indupalma. Indupalma, Bogotá, Colombia.

Pulido, L., 1996. Environmentalism and Economic Justice: Two Chicano Struggles in the Southwest. University of Arizona Press, Tucson, AZ.

Pye, O,. 2010. The biofuel connection - transnational activism and the palm oil boom. The Journal of Peasant Studies, 37(4), 851-874.

Ramón Jácome, G.A., 2010. La Cooperación Internacional de la Unión Europea y los

Desafíos Reales del Desplazamiento Forzado en Colombia: Análisis Crítico en el Magdalena Medio. Bachelor thesis, Pontificia Universidad Javeriana, Bogotá, Colombia.

Rangel, A., Ramírez Tobón, W., Betancur, P.A., Cifuentes, F., Hurtado, G., 2009. La palma africana: mitos y realidades del conflicto. Fundación Seguridad y Democracia, Bogotá, Colombia.

Reales Castilla, R.D., 2009. Evaluación de Alianzas Estratégicas en Palma Aceitera en los Municipios de la Jagua de Ibirico y Becerril, Departamento del Cesar. Master thesis. Universidad Nacional de Colombia, Bogotá, Colombia.

Restrepo, E., 2004. Un Océano Verde para Extraer Aceite. Hacia una Etnografía del Cultivo de la Palma Africana en Tumaco. Universitas Humanística XXXI(58), 72-87.

Revista Cambio, 2009. Programa Agro Ingreso Seguro ha beneficiado a hijos de políticos y reinas de belleza. Revista Cambio, Bogotá, Colombia. Available at: http://www.cambio.com.co/paiscambio/847/ARTICULO-WEB-

NOTA_INTERIOR_CAMBIO-6185730.html (Accessed May 31, 2013).

Revista Dinero, 2012. Puro cuento... japonés. Revista Dinero, Bogotá, Colombia. Available at: http://www.dinero.com/Imprimir.aspx?idItem=154190 (Accessed July 3, 2013).

Reyes Posada, A., 2009. Guerreros y campesinos: el despojo de la tierra en Colombia. Grupo Editorial Norma, Bogotá, Colombia.

Reyes Posada, A., Duica Amaya, L., Pedraza, W.A., 2009. Identificación de los agentes colectivos responsables del abandono de tierras en los municipios colombianos. Agencia Presidencial para la Acción Social y la Cooperación Internacional, Bogotá, Colombia.

Reyes Posada, A., Duica Amaya, L., Pedraza, W.A., 2010. El despojo de tierras por paramilitares en Colombia. Mimeo, Bogotá, Colombia.

Ribot, J.C., 1998. Theorizing access: Forest Profits along Senegal's Charcoal Commodity Chain. Development and Change 29(2), 307-341. 
Ribot, J.C., Peluso, N.L., 2003. A Theory of Access. Rural Sociology 66(2), 153-181.

Rice, T., 2010. Meals per gallon: The impact of industrial biofuels on people and global hunger. ActionAid UK, London.

Risse, T., 2006. Transnational Governance and Legitimacy, in Benz A., Papadopoulos, I., (Eds.), Governance and Democracy: Comparing National, European and International Experiences. Routledge, London, pp. 179-99.

Rist, L., Feintrenie, L., P. Levang, P., 2010. The livelihood impacts of oil palm: smallholders in Indonesia. Biodiversity Conservation 19(4), 1009-1024.

Robbins, P., 2004. Political Ecology: A Critical Introduction. Blackwell Publishing, Oxford and Cambridge.

Robbins, P., 2012. Political Ecology: A Critical Introduction, 2nd edition. Wiley-Blackwell, Oxford.

Rocheleau, D., 2008. Political ecology in the key of policy: From chains of explanation to webs of relation. Geoforum 39(2), 716-727.

Rocheleau, D., Ross, L., 1995. Trees as tools, trees as text: struggles over resources in Zambrana-Chacuey, Dominican Republic. Antipode 27(4), 407-428.

Rocheleau, D., Thomas-Slayter B., Wangari E. (Eds.), 1996. Feminist Political Ecology: Global issues and local experiences. Routledge, New York.

Rodríguez-Becerra, M., Van Hoof, B., 2005. Environmental Performance of the Colombian Oil Palm Industry. Fedepalma, Bogotá, Colombia.

Ross, M.L., 2004. How do Natural Resources Influence Civil War? Evidence from Thirteen Cases. International Organization 58(1), 35-67.

Rothkopf, G., 2007. A Blueprint for Green Energy in the Americas. Strategic Analysis of Opportunities for Brazil and the Hemisphere. Featuring: The Global Biofuels Outlook 2007. Inter American Development Bank, Washington, D.C.

RSPO, 2007. RSPO Certification Systems. RSPO, Geneva. Available at: http://www.rspo.org/sites/default/files/RSPOcertification-systems.pdf (Accessed September 3, 2012).

RSPO, 2013. Colombia National Interpretation Taskforce (NITF) Composition - Members \& Alternates. Available at:

http://www.rspo.org/file/Colombia\%20NI_Letter_Composition.pdf (Accessed March 23, 2014).

San Alberto's Mayor's office, no date available. San Alberto - Cesar, Puerta de Oro del Sur del Cesar. Available at: http://sites.google.com/site/datosdesanalbertocesar/ (Accessed September 12, 2013).

Santos, B., 2002. Toward a Multicultural Conception of Human Rights, in HernándezTruyol, B. (Ed.), Moral Imperialism - A Critical Anthology. New York University Press, New York, pp. 39-60. 
Santos, B., 2006. Conocer desde el Sur. Para una cultura política emancipatoria. Fondo Editorial de la Facultad de Ciencias Sociales de la Universidad Mayor de San Marcos, Lima.

Santos, B., 2007. Human Rights as an Emancipatory Script? Cultural and Political Conditions, in Santos, B. (Ed.), Another Knowledge is Possible. Beyond Northern Epistemologies. Verso, London, pp. 1-40.

Santos, B., 2012. Public Sphere and Epistemologies of the South. Africa Development XXXVII(1), 43-67.

Santos, B., Rodríguez-Garavito, C., 2005. Law, politics, and the subaltern in counterhegemonic globalization, in Santos, B., Rodríguez-Garavito, C. (Eds.), Law and Globalization from Below. Towards a Cosmopolitan Legality. Cambridge University Press, Cambridge.

Scharpf, F.W., 1997. Economic integration, democracy and the welfare state. Journal of European Public Policy 4, 18-36.

Schlosberg, D., 2004. Reconceiving environmental justice: global movements and political theories. Environmental Politics 13(3), 517-540.

Schlosberg, D., 2007. Defining Environmental Justice: Theories, Movements, and Nature. Oxford University Press, New York.

Schlosberg, D., Carruthers, D., 2010. Indigenous Struggles, Environmental Justice, and Community Capabilities. Global Environmental Politics 10(4), 12-35.

Schmidt, J.H., Weidema, B.P., 2008. Shift in the Marginal Supply of Vegetable Oil. The International Journal of Life Cycle Assessment 13(3), 235-239.

Schouten, G., Glasbergen, P., 2011. Creating legitimacy in private global governance: The case of the Roundtable on Sustainable Palm Oil. Ecological Economics 70(11), 18911899.

Schroeder, R., St Martin, K., Wilson, B., Sen, D. (Eds.), 2008. Special issue: Third World Environmental Justice. Society and Natural Resources 21(7).

Scott, J.C. 1985. Weapons of the Weak: Everyday Forms of Peasant Resistance. Yale University Press, New Haven.

Scott, J.C., 1998. Seeing Like a State. How Certain Schemes to Improve the Human Condition Have Failed. Yale University Press, New Haven.

Seebolt, S., Salinas, Y., 2010. Responsibility and Sustainability of the palm oil industry. Are the Principles and Criteria of the RSPO feasible in Colombia?. Oxfam Novib Indepaz, Bogotá, Colombia.

Segura, F., 2008. Palma de aceite y conflicto armado en Colombia: Una exploración de la economía política de la palma de aceite en las regiones colombianas. Master thesis. Universidad de los Andes, Bogotá, Colombia.

Sen, A., 1990. Justice: Means versus Freedoms. Philosophy and Public Affairs 19(2), 111121. 
Sen, A., 1999. Development as Freedom. Oxford University Press, Oxford.

Sen, A., 2009. The Idea of Justice. Harvard University Press, Cambridge, Massachusetts.

SGS - Société Générale de Surveillance, 2010. The DAABON Group oil palm plantation management verification report. SGS, Kuala Lumpur. Available at:

http://www.rspo.org/sites/default/files/MY02299-

06\%20CI\%20Tequendama\%202010\%2010\%20Summary\%20Report\%20Rev2.pdf

(Accessed February 10, 2014).

Sheil, D., Casson, A., Meijaard, E., van Nordwijk, M., Gaskell, J., Sunderland-Groves, J., Wertz, K., Kanninen, M., 2009. The impacts and opportunities of oil palm in Southeast Asia: What do we know and what do we need to know?. Occasional paper No. 51. CIFOR, Bogor.

Sikor, T., 2006. Analyzing community-based forestry: Local, political and agrarian perspectives. Forest Policy and Economics 8(4), 339-349.

Sikor, T., and Lund, C., 2009. Access and Property: A Question of Power and Authority. Development and Change 40(1), 1-22.

Sirait, M.T., 2009. Indigenous Peoples and Oil Palm Plantation Expansion in West Kalimantan, Indonesia. Indonesia country report prepared for the study: Environmental degradation, natural resources and violent conflict in indigenous habitat in KalimantanIndonesia, Bayaka-Central African Republic and San Marcos-Guatemala. Amsterdam University - Cordaid, The Hague.

SISPA - Statistics Information System of the Palm Oil Sector. http://sispa.fedepalma.org/sispaweb/default.aspx (Accessed May 31, 2013).

Smith, N., 1984. Uneven Development. Blackwell, Oxford.

SNR - Superintendencia de Notariado y Registro, 2013. Para que los colombianos recuperen su tierra. SNR, Bogotá, Colombia. Available at:

https://www.supernotariado.gov.co/portalsnr/images/archivosupernotariado/DelegadaT ierras2013/Publicaciones/De\%201a\%20proteccion\%20y\%20el\%20registro1.pdf (Accessed March 19, 2014).

Soler, J.P., León, D., 2009. Impactos ambientales de la expansión de Palma Aceitera en el Magdalena Medio, hablan los pobladores - Estudio de Caso Las Pavas. Asociación Campesina de Cacaoteros de Buenos Aires (ASOCAB) - Programa de Desarrollo y Paz del Magdalena Medio, Magdalena Medio, Colombia.

Stonich, S.C,, Vandergeest, P., 2001. Violence, Environment, and Industrial Shrimp Farming, in Peluso, N.L., Watts, M. (Eds.), Violent Environments. Cornell University Press, Ithaca and London, pp. 261-286.

Svampa, M., 2008. La disputa por el desarrollo: territorios y lenguajes de valoración, in Svampa, M., Cambio de época. Movimientos sociales y poder político. Siglo XXI, Buenos Aires, pp. 93-114. 
Svampa, M., 2011. Resource Extractivism and Alternatives: Latin American Perspectives on Development, in Lang, M., Mokrani, D. (Eds.), Beyond Development: Alternative visions from Latin America, First translated edition 2013. Transnational Institute Rosa Luxemburg Foundation, Amsterdam and Quito, pp. 117-144.

Swyngedouw, E., 1997. Neither Global nor Local: "Glocalisation" and the politics of scale, in Cox, K.R, Spaces of Globalisation: Reasserting the Power of the Local. The Guilford Press, London, pp. 137-166.

Swyngedouw, E., 2004. Scaled geographies: nature, place and the politics of scale, in

Sheppard, E., McMaster, R.B. (Eds.), Scale and geographic inquiry. Blackwell, Oxford, pp. 129-53.

Swyngedouw, E., 2005. Governance Innovation and the Citizen: The Janus Face of Governance-beyond-the-State. Urban Studies 42(11), 1991-2006.

Swyngedouw, E., Heynen, N.C., 2003. Urban Political Ecology, Justice and the Politics of Scale. Antipode 35(5), 898-918.

Take, I., 2012. Legitimacy in Global Governance: International, Transnational and Private Institutions Compared. Swiss Political Science Review 18(2), 220-248.

Tamm Hallström, K., Boström. M., 2010. Transnational Multi-Stakeholder Standardization: Organizing Fragile Non-State Authority. Edward Elgar, Cheltenham, UK.

Taylor, P.L., 2005. In the Market But Not of It: Fair Trade Coffee and Forest Stewardship Council Certification as Market-Based Social Change. World Development 33(1), 129147.

Temper, L., Martinez-Alier, J., 2013. The god of the mountain and Godavarman: Net Present Value, indigenous territorial rights and sacredness in a bauxite mining conflict in India. Ecological Economics 96, 79-87.

The Observer, 2009. Body Shop ethics under fire after Colombian peasant evictions. The observer online. Available at: http://www.theguardian.com/world/2009/sep/13/bodyshop-colombia-evictions (Accessed August 31, 2013).

The Rainforest Foundation UK, 2013. Seeds of Destruction - Expansion of Industrial Oil Palm in the Congo Basin: Potential Impacts on Forests and People. The Rainforest Foundation UK, London.

Thoenes, P., 2007. Biofuels and Commodity Markets - Palm Oil Focus. Food and Agriculture Organization (FAO), Rome.

Transparencia por Colombia, 2006. Los donantes de la campaña presidencial de Álvaro Uribe. Transparencia por Colombia. Available at lwww.semana.com/documents/Doc1256_200668.pdf (Accessed March 5, 2011).

Tribunal Superior del Distrito Judicial de Cúcuta, 2013. Sentencia No. 5400122210022013-00026-00.

Tudela, J.W., Rosales, R., Samacá, H., 2004. Un análisis empírico del Fondo de Estabilización de Precios en el mercado de aceite de palma colombiano. Universidad de 
los Andes, Centro de Estudios sobre Desarrollo Económico (CEDE), Bogotá, Colombia.

UN - United Nations, 2007. Report of the Special Rapporteur on the right to food, Jean Ziegler, submitted in accordance with General Assembly resolution 61/163. UN document A/62/289.

UN - United Nations, 2008. Report of the Special Rapporteur on the right to food, Jean Ziegler. UN document A/HRC/7/5.

Urkidi, L., 2010. A glocal environmental movement against gold mining: Pascua-Lama in Chile. Ecological Economics 70(2), 219-227.

Urkidi, L., Walter, M., 2011. Dimensions of environmental justice in anti-gold mining movements in Latin America. Geoforum 42(6), 683-695.

USAID - United States Agency for International Development, 2010. Portafolio de Proyectos de Palma de Aceite Apoyados por USAID (Estatus a diciembre de 2009). Presentation at the meeting of palm oil municipalities, Bogotá, Colombia on February 10, 2010. Available at: http://portal.fedepalma.org//discursos.htm (Accessed July 22, 2013).

Vanguardia, 2012. Palmeros de Sabana pidieron el pago por convenio a Indupalma. Vanguardia.com. Available at:

http://www.vanguardia.com/santander/barrancabermeja/184934-palmeros-de-sabanapidieron-el-pago-por-convenio-a-indupalma (Accessed March 23, 2014).

Vargas, R., Mow, J.M., Pérez, M., Rivas, A., 2010. Report Independent Commission Land Conflict - Las Pavas - Bolívar, Colombia. Body Shop - Christian Aid, Bogotá, Colombia. Available at: http://www.christianaid.org.uk/images/laspavasreport.pdf (Accessed September 12, 2013).

Vargas Meza, R., 2010. Desarrollo Alternativo en Colombia y Participación Social: propuestas hacia un cambio de estrategia. Diálogo Inter-Agencial en Colombia, Bogotá, Colombia.

Vargas Tovar, E., 2002. The 1960's and 1970's Oil Palm: From Farm to Enterprises. Palmas 23(3), 86-92.

Vayda, A.P., Walters, B.B., 1999. Against Political Ecology. Human Ecology 27(1), 167179.

Vélez, I. (Ed.), 2008. Agrocombustibles: Llenando tanques, vaciando territorios. CENSAT Agua Viva - Proceso de Comunidades Negras, Bogotá, Colombia.

Verdad Abierta, 2011a. Tierra Prometida en la Bellacruz. Verdadabierta.com. Available at: http://www.verdadabierta.com/component/content/article/158-captura-de-rentaspublicas/3530-tierra-prometida-en-la-bellacruz/ (Accessed July 25, 2013).

Verdad Abierta, 2011b. Las trampas de la Bellacruz. Verdadabierta.com. Available at: http://www.verdadabierta.com/component/content/article/197-paraeconomia/3424-lastrampas-de-bellacruz (Accessed July 25, 2013). 
Verdad Abierta, 2012. El secreto de Mapiripán. Verdadabierta.com. Available at: http://www.verdadabierta.com/el-secreto-de-mapiripan (Accessed July 25, 2013).

Verdad Abierta, 2013a. En la Bellacruz hay 1200 hectáreas de baldíos y deben restituirse. Verdadabierta.com. Available at:

http://www.verdadabierta.com/component/content/article/48-despojo-de-tierras/4520mil-200-hectareas-de-la-bellacruz-son-baldios-y-deben-restituirse-incoder (Accessed July 25, 2013).

Verdad Abierta, 2013b, Tres agroindustrias de los Llanos compraron tierras con líos y violencia. Verdadabierta.com. Available at:

http://www.verdadabierta.com/tres-agroindustrias-de-los-llanos-compraron-tierras-conlios-y-violencia (Accessed July 25, 2013).

Verdad Abierta, 2013c. Pitalito, Cesar, una vereda entre el despojo y el desalojo. Verdadabierta.com. Available at: http://www.verdadabierta.com/tierras/despojo-detierras/4660-pitalito-cesar-una-vereda-entre-el-despojo-y-el-desalojo (Accessed March 23, 2014).

Verdad Abierta, 2013d. Se agrava conflicto por predio en Pitalito, Cesar. Verdadabierta.com. Available at: ttp://www.verdadabierta.com/tierras/la-lucha-por-latierra/5059-se-agrava-conflicto-por-predio-en-pitalito-cesar (Accessed March 23, 2014).

Veuthey, S., Gerber, J-F., 2011. Valuation Contests over the Commoditisation of the Moabi Tree in South-Eastern Cameroon. Environmental Values 20(2), 239-264.

Vidal Tovar, C., Villarroel, I., 2011. Alianzas Estratégicas para el Cultivo de Palma Aceite. Una Metodología de Recuperación e Integración Agroindustrial en María la Baja, Departamento de Bolívar, Colombia. Tecnología, Gerencia y Educación 12(24), 145 159.

Wagle, S., Warghade, S., Sathe, M., 2012. Exploiting policy obscurity for legalising water grabbing in the era of economic reform: The case of Maharashtra, India. Water Alternatives 5(2), 412-430.

von Geibler, J., 2012. Market-based governance for sustainability in value chains: conditions for successful standard setting in the palm oil sector. Journal of Cleaner Production 56, 39-53.

Votebien.com, 2006. Financiación campañas en las elecciones presidenciales 2002. Votebien.com Available at:

http://www.terra.com.co/elecciones_2006/centro_de_documentacion/informeuribe.pdf (Accessed March 5, 2011).

Wakker, E., 2005. Greasy palms: the social and ecological impacts of large-scale oil palm plantation development in Southeast Asia. Friends of the Earth, London.

Walker, P.A., 2005. Political ecology: where is the ecology?. Progress in Human Geography 29(1), 73-82. 
Walker, G., Bulkeley, H. (Eds.), 2006. Themed Issue: Geographies of environmental justice, of Geoforum 37(5), 665-738.

Walter, M., Martinez-Alier, J., 2010. How to Be Heard When Nobody Wants to Listen: Community Action against Mining in Argentina. Canadian Journal of Development Studies 30(1-2), 281-303.

Watts, M., 2004. Violent environments: petroleum conflict and the political ecology of rule in the Niger Delta, Nigeria, in Peet, R., Watts, M. (Eds.), Liberation Ecologies: environment, development, social movements, 2nd edition. Routledge, London/New York, pp. 250-272.

Watts, M., Peet, R., 2004. Liberating Political Ecology, in Peet, R., Watts, M. (Eds.), Liberation Ecologies: environment, development, social movements, 2nd edition. Routledge, London/New York, pp. 3-43.

WB - The World Bank, IFC - International Finance Corporation, 2011. The World Bank Group Framework and IFC Strategy for Engagement in the Palm Oil Sector. WB IFC, Washington, D.C.

White, B., Dasgupta, A., 2010. Agrofuels capitalism: a view from political economy. The Journal of Peasant Studies 37(4), 593-607.

Whittington, E., 2009. Growing Pains: The Possibilities and Problems of Biofuels. Christian Aid, London.

World Growth, 2009. Palm oil: The sustainable oil. World Growth, Arlington.

WRM - World Rainforest Movement, 2006. Oil Palm: From Cosmetics to Biodiesel. Colonization Lives On. WRM, Montevideo.

Yin, R., 2009. Case study research: design and methods, 4th edition. Sage publications, Thousand Oaks, CA.

Zografos, C., Howarth, R.B., 2010. Deliberative Ecological Economics for Sustainability Governance. Sustainability 2(11), 3399-3417. 


\section{Summary}

The current model of world economic development largely rests on the global expansion of commodity frontiers, i.e. "the production and distribution of specific commodities, and of primary goods in particular, that have restructured geographic spaces in such a way as to require further expansion" (Moore, 2000: 410). In this new millennium, the expansion of commodity frontiers is unfolding at an unprecedented rate and scale that it has set the scene for a proliferation of socio-environmental conflicts (Muradian et al., 2012).

Several studies suggest a remarkable increase since the mid-1990s in the intensity of both physical and biological resource extraction, especially in the Global South. The extraction route has led to a growing number of struggles in which access by "socially disadvantaged groups" (Bryant, 1992) to the environments that constitute the basis of their livelihoods and culture is defended against the interests of powerful actors pursuing different and often conflicting use and exploitation of those environments.

The currently accelerating expansion of "commodity frontiers" is taking place at the global scale. However, country-specific geographies and their social, political and economic processes shape the ways in which the expansion of a specific commodity frontier unfolds in a particular country. In this thesis, I use the concept of 'country-specific trajectories of commodity frontiers expansion' to refer to the specific ways in which the expansion of commodity frontiers unfolds in a particular country. Country-specific trajectories involve different practices in order to gain, control or maintain access to a resource. These practices are often shaped by government incentives to support extractive activities and hence these incentives define power asymmetries between actors in access to resources. Countryspecific trajectories also encompass the different responses from local social actors situated in the places where expansion takes place. These responses often take the form of struggle and contestation in defence of livelihoods. Contestation and conflict are signs of, and responses to, the injustices enmeshed in such threats to livelihoods (Martinez-Alier, 2013). Non-state market-driven (NSMD) governance mechanisms, such as voluntary certification schemes, have become one of the global governance mechanisms commonly used to address the socio-environmental concerns associated with the expansion of agro-industrial commodities extraction that are at the core of conflict and contestation. However, the processes of adoption and implementation of the certification standards at the national scale often constitute arenas where contestation occurs, thereby challenging the legitimacy of the governance system. Legitimacy contestation may be rooted in: i) the different values of the local actors vis-à-vis the values that the governance system represents, and ii) decisionmaking procedures not taking into account such plurality of values. Local actors that dispute the expansion of commodity frontiers may resort to different strategies outside 
NSMD governance systems to articulate their resistance, especially when there is contestation of the legitimacy of these governance systems. Human rights politics is often used as a strategy of resistance in parallel to other strategies. This reliance on human rights politics can be explained by the fact that the human rights framework encompasses the various dimensions of justice that underlie the claims of resisting actors. These claims include equitable distribution of access to resources, recognition of difference in identity and culture, equal participation and freedom to pursue the lives people value to lead (Schlosberg, 2007). Thus, in the analysis of country-specific trajectories of expansion of commodity frontiers, important elements include the factors that influence the legitimacy contestation of NSMD sustainability governance systems at the national scale, as well as local actors' strategies of resistance and their potential for emancipatory politics.

The main objective of this thesis is to provide new insights into how the expansion of commodity frontiers is manifested in country-specific trajectories of resource access, control and contestation. Based on this objective, the overarching research question addressed in this dissertation is: how is the expansion of commodity frontiers manifested in country-specific trajectories of inequitable resource access?

I address this research question from a political ecology perspective by analysing the expansion of the palm oil frontier in Colombia between 2000 and 2010, and the resourceaccess struggles and resistance connected with this expansion. The global expansion of the palm oil frontier occurs at different rates and scales across countries that represent very different contexts in which to study country-specific trajectories of commodity frontier expansion. Palm oil production especially takes place in the Global South in tropical areas of Africa, Asia and Latin America where the appropriate agro-climatic conditions are found to grow the oil palm tree. Indonesia, Malaysia, Thailand, Nigeria and Colombia are the world's five leading producers. The global palm oil market has experienced a remarkable boom since 2000. Global production increased from 21.8 million tonnes in 2000 to 45.8 million tonnes in 2010. The rise in palm oil production has led to an accelerated expansion of oil palm cultivation in producing countries, raising questions about the resulting locallevel socio-environmental impacts. Colombia is a relevant case for analysing how the global expansion of commodity frontiers is manifested in country-specific trajectories of control over access to resources, and contestation. It is one of the world's leading producers of palm oil and the expansion of the frontier accelerated across a large area between 2000 and 2010. The amount of land cultivated with oil palm almost tripled from 157,000 hectares in 2000 to 404,000 hectares in 2010. Moreover, the country has been repeatedly cited in negative terms in the literature dealing with the socio-environmental impacts of palm oil expansion. Several cases of resource access struggles and socio-environmental conflicts 
have been reported by researchers, journalists, and non-governmental and grassroots organizations.

The research was approached from the perspective of political ecology using the 'extended case' method. I also used concepts and insights from other fields to enrich the analytical potential of political ecology. In particular, concepts from ecological economics, political economy, peasant studies and critical sociology, as well as theories of environmental justice and human rights.

The political ecology scholarship has already demonstrated that resource control practices linked to commodity frontier expansion often take the form of 'accumulation by dispossession', i.e. capital accumulation by certain human groups at the expense of the livelihoods of others (Harvey, 2003). This dissertation shows: i) that resource control practices also take the form of 'assimilation', i.e. practices of incorporation of local populations into modern processes in an attempt to realise a measure of equity while denying differences rooted in identity and culture (Escobar 2006a and 2006b); and ii) that both 'accumulation by dispossession' and 'assimilation' may be manifested in multiple and varied practices at country and local levels that produce inequitable access to resources. The analysis of a number of cases of resistance connected with the expansion of the palm oil frontier in Colombia shows six types of country-specific practices of 'accumulation by dispossession' used to gain control over land for the expansion of the palm oil frontier, while 'assimilation' was embodied in some of the contract farming arrangements referred to as 'productive alliances'. Through these practices, actors interested in the expansion of the palm oil frontier gained control over access to land, while local populations lost, or risked losing, control over the resources that sustain their livelihoods or accepted 'assimilation' practices at odds with their identity and 'lifeworlds' in order to maintain their access to resources.

The expansion of a commodity frontier at the national level and the forms that resourcecontrol practices take at the local level are shaped by country-specific socio-economic and political processes and national geographies, as well as by the material requirements and characteristics of the commodity. These factors define the physical spaces where expansion takes place and how control over access to resources is gained, lost or maintained by various actors in such spaces. In Colombia, the expansion of oil palm cultivation between 2000 and 2010 was strongly influenced by an increasing national production of palm oil to be processed into biodiesel for the national market. This increasing production was driven by governmental policies that promoted national biofuel production and consumption, and supported palm oil production as a feedstock. Governmental support to the palm oil agroindustry, peasant marginalization and socio-political processes connected with the armed 
conflict shaped the country-specific 'accumulation by dispossession' and 'assimilation' practices used to control land for the expansion of oil palm cultivation.

The 2000-2010 expansion of the palm oil frontier in Colombia shows that governmental support for extractive activities is a very relevant factor in mediating actors' power asymmetries in access to resources in commodity frontiers. Such support results in inequitable outcomes when it translates into structural and relational mechanisms of access that facilitate 'accumulation by dispossession' and 'assimilation' practices. Governmental support for extractive activities varies from country to country because: i) each country can adopt a different set of incentives; and ii) the webs of relations that influence who benefits from incentives, and how, is also context-specific. As a consequence, the power asymmetries in access to resources may vary from one country to another, and also within countries.

The empirical study contained in this thesis shows that the inequitable access to resources resulting from 'accumulation by dispossession' and 'assimilation' practices is expressed in threats to various dimensions of a local population's livelihoods. These threats represent grievances affecting the distribution, recognition, capabilities and participation dimensions of justice. The responses to such threats and grievances by local populations are contextspecific. When there is resistance, several context- and case-specific factors determine the emancipatory potential of resistance. The empirical findings show that support from third parties (for example, NGOs, grassroots organizations, Ombudsman Offices, courts) and the types of resistance mechanisms used are key factors in determining emancipatory outcomes. One of the cases of peasant resistance analysed in this thesis shows that human rights politics is a powerful instrument of resistance when the human rights normative framework is applied and interpreted in accordance with a local populations' constellation of meanings.

Finally, the analysis of the Roundtable on Sustainable Palm Oil (RSPO) national interpretation process in Colombia demonstrates that resistance in socio-environmental conflicts can be reproduced in the legitimacy contestation of NSMD governance instruments at the national level. The study of the RSPO in Colombia also demonstrates that legitimacy contestation occurs when the decision-making process reproduces local and national power asymmetries and overlooks the values of the local populations. This explains why local actors that dispute the expansion of commodity frontiers resort to strategies outside of NSMD governance systems to articulate their resistance. 


\section{Resumen}

El actual modelo de desarrollo económico mundial se basa en gran medida en la expansión global de las fronteras de las materias primas o fronteras extractivas (commodity frontiers), es decir, "la producción y distribución de materias primas, y de bienes primarios en particular, que ha reestructurado los espacios geográficos de tal manera que se requiere una mayor expansión" (Moore, 2000: 410). En este nuevo milenio, la expansión de las fronteras extractivas se está desarrollando a un ritmo y a una escala sin precedentes, dando así lugar a la proliferación de conflictos socio-ambientales (Muradian et al., 2012).

Varios estudios sugieren un aumento notable en la intensidad de la extracción física y biológica de recursos desde mediados de la década de 1990, especialmente en el Sur Global. La ruta de la economía extractiva ha llevado a un número cada vez mayor de disputas en las que "grupos socialmente desfavorecidos" (Bryant, 1992) luchan por defender el acceso a los territorios que constituyen la base de sus medios de vida y de su cultura contra los intereses de actores poderosos que pretenden explotar dichos territorios de manera incompatible con los medios de vida de los habitantes locales.

La expansión acelerada de las fronteras extractivas se está produciendo a escala global. Sin embargo, las geografías específicas de cada país y sus procesos sociales, políticos y económicos definen la manera en la que la expansión de una frontera extractiva específica se desarrolla en un país determinado. En esta tesis doctoral se usa el concepto "trayectoriaspaís de expansión de las fronteras extractivas" para hacer referencia a la forma que toma la expansión de una frontera extractiva en un país determinado. Tales trayectorias comprenden las diferentes prácticas a las que acuden los actores interesados en expandir la frontera extractiva para ganar, controlar o mantener el acceso a los recursos. Estas prácticas son a menudo influenciadas por los incentivos gubernamentales de apoyo a las actividades extractivas. Por lo tanto, estos incentivos definen asimetrías de poder entre diferentes actores en relación con el acceso a los recursos. Las trayectorias-país de expansión de las fronteras extractivas también se refieren a las diferentes respuestas de los actores locales que habitan en los lugares donde la expansión se lleva a cabo. Estas respuestas suelen adoptar la forma de luchas y disputas contra las amenazas que la expansión de la frontera extractiva representa para los medios de vida de las poblaciones locales. La resistencia y el conflicto son señales de, y respuestas a las injusticias que representan este tipo de amenazas a los medios de vida locales (Martínez-Alier, 2013). Los instrumentos de gobernanza no estatales y basados en consideraciones de mercado (Non-State Market-Based - NSMD), como por ejemplo los esquemas de certificación voluntaria, se han convertido en uno de los mecanismos de gobernanza global de uso común para hacer frente a las preocupaciones por los efectos socio-ambientales asociados a la expansión de la extracción de materias primas 
agro-industriales que están al centro de los conflictos socio-ambientales. Sin embargo, los procesos de adopción y aplicación a nivel nacional de las criterios y principios de certificación establecidos a nivel internacional, con frecuencia constituyen escenarios donde se produce el rechazo de tales sistemas de gobernanza (NSMD), afectando así la legitimidad de los mismos. Dicho rechazo puede tener sus raíces en: i) la diferencia entre los valores de los actores locales y los valores que el sistema de gobernanza representa, y ii) procedimientos de toma de decisiones que no tienen en cuenta tal pluralidad de valores. Los actores locales que se oponen a la expansión de las fronteras extractivas pueden recurrir a diferentes estrategias fuera de estos sistemas de gobernanza para articular su resistencia, especialmente cuando la legitimidad de los mismos es cuestionada. Los actores locales a menudo recurren a la acción política basada en derechos humanos como una estrategia de resistencia en paralelo con otras estrategias. Esta preferencia por la acción política basada en derechos humanos se puede explicar por el hecho de que el marco normativo de derechos humanos abarca las diversas dimensiones de justicia representadas en los reclamos de los actores locales que se resisten. Estos reclamos incluyen la distribución equitativa de acceso a los recursos; el reconocimiento de la diferencia, la identidad y la cultura; la igualdad de participación; y libertad para conducir la vida que los actores valoran vivir (Schlosberg, 2007). De consecuencia, para el estudio de las trayectorias-país de expansión de las fronteras extractivas es importante incluir el análisis de los factores que afectan la legitimidad a escala nacional de los sistemas de gobernanza NSMD, así como las estrategias de resistencia de los actores locales y su potencial emancipador.

El objetivo principal de esta tesis es proporcionar nuevos conocimientos sobre cómo se manifiesta la expansión de las fronteras extractivas en trayectorias-país de acceso al control de los recursos y de resistencia en relación con dicha expansión. En consecuencia, la pregunta de investigación general abordada en esta disertación es: ¿cómo la expansión de las fronteras extractivas se manifiesta en trayectorias-país de injusticia en el acceso a los recursos?

Esta pregunta de investigación es abordada desde la perspectiva de la ecología política a través del análisis tanto de la expansión de la frontera palmera (cultivo de palma aceitera, y producción y comercialización de aceite de palma) en Colombia en el periodo 2000-2010, como de la resistencia y las disputas por el acceso a los recursos relacionadas con dicha expansión. La expansión global de la frontera palmera se produce a ritmos y escalas diferentes entre los países productores, los cuales representan contextos diferentes en los que se pueden estudiar las diferentes trayectorias-país de la expansión de esta frontera extractiva. La producción de aceite de palma se lleva a cabo en el Sur Global, en las zonas tropicales de África, Asia y América Latina, donde se encuentran las condiciones agroclimáticas adecuadas para el cultivo de la palma de aceite. Indonesia, Malasia, Tailandia, 
Nigeria y Colombia son los cinco principales productores mundiales de aceite de palma. El mercado mundial de aceite de palma ha experimentado un auge notable desde el año 2000. La producción mundial aumentó de 21,8 millones de toneladas en 2000 a 45,8 millones de toneladas en 2010. El aumento de la producción de aceite de palma ha llevado a una expansión acelerada del cultivo de palma aceitera en los países productores, generando preocupación por los impactos socio-ambientales de dicha expansión a nivel local. El caso de la expansión de la frontera palmera en Colombia es relevante para analizar cómo se manifiesta la expansión global de las fronteras extractivas en trayectorias-país en relación con el control sobre el acceso a los recursos y las consecuentes disputas y procesos de resistencia. Colombia es uno de los principales productores mundiales de aceite de palma y la expansión de la frontera palmera se aceleró entre los años 2000 y 2010. La cantidad de tierra cultivada con palma de aceite casi se triplicó pasando de 157.000 hectáreas en el año 2000 a 404.000 hectáreas en el año 2010. Además, el país ha sido citado varias veces en términos negativos en la literatura sobre los impactos socio-ambientales de la expansión de la frontera palmera. Varios casos de disputas por el acceso a los recursos y conflictos socioambientales han sido reportados por los investigadores, periodistas, organizaciones no gubernamentales y organizaciones de base.

La investigación contenida en esta tesis se aborda desde la perspectiva de la ecología política haciendo uso de la metodología "estudio de caso extendido" (extended case method). También se usan conceptos de otras disciplinas para enriquecer el potencial analítico de la ecología política, en particular, conceptos de economía ecológica, economía política, estudios rurales y sociología crítica, así como también teorías de justicia ambiental y derechos humanos.

Los estudios desde la ecología política han demostrado que las prácticas de control de recursos vinculadas a la expansión de las fronteras extractivas a menudo toman la forma de "acumulación por desposesión", es decir, la acumulación de capital por ciertos grupos humanos a expensas de los medios de vida de otros (Harvey, 2003). Esta tesis doctoral demuestra: i) que las prácticas de control de recursos también toman la forma de "asimilación": prácticas de incorporación de las poblaciones locales a los procesos modernos de desarrollo - en un intento por alcanzar en alguna medida la equidad - que desconocen y niegan las diferencias originadas en la identidad y la cultura (Escobar 2006a y 2006b); y ii) que tanto la "acumulación por desposesión" como la "asimilación" pueden manifestarse a nivel nacional y local en múltiples y variadas prácticas que producen injusticias en relación con el acceso a los recursos. El análisis empírico del caso colombiano contenido en esta tesis muestra que, por una parte, hay seis tipos de prácticas de "acumulación por desposesión" que han sido utilizadas para obtener el control de la tierra para la expansión de la frontera palmera en Colombia. Por otra parte, la "asimilación” está 
representada por algunos de los contratos de producción agrícola conocidos como "alianzas productivas", a través de las cuales poseedores de pequeñas parcelas son integrados a una empresa productora de aceite de palma en calidad de pequeños cultivadores de palma para abastecer de fruto de palma a la empresa productora de aceite. A través de estas prácticas de “acumulación por desposesión” y "asimilación” los actores interesados en la expansión de la frontera palmera han podido obtener el control sobre el acceso a la tierra, mientras que las poblaciones locales pierden o quedan en riesgo de perder el control sobre los recursos que sustentan sus medios de vida, o aceptan prácticas de "asimilación" que entran en contradicción con su identidad y sus formas de vida con el fin de poder mantener su acceso a los recursos.

La expansión de una frontera extractiva a nivel nacional y las formas que dicha expansión toma a nivel local en términos de control de los recursos están determinadas por los procesos socio- económicos y políticos específicos del país, por la geografía nacional, y por los requerimientos materiales y las características de la actividad extractiva o el producto a extraer. Estos factores definen los espacios físicos donde la expansión se lleva a cabo y la forma en que diversos actores adquieren, pierden o mantienen el control sobre el acceso a los recursos en estos espacios. En Colombia, la expansión del cultivo de palma aceitera entre 2000 y 2010 estuvo fuertemente influenciada por un aumento de la producción nacional de aceite de palma para la transformación en biodiesel para el mercado nacional. El aumento en el cultivo de palma fue impulsado por las políticas gubernamentales para la promoción de la producción y consumo de biocombustibles a nivel nacional, y el apoyo a la producción de aceite de palma como materia prima para la producción de biodiesel. El apoyo gubernamental a la agroindustria de la palma de aceite, la marginalización de las poblaciones campesinas y los procesos socio-políticos relacionados con el conflicto armado han dado forma a las prácticas específicas de "acumulación por desposesión" y "asimilación" que se han utilizado en Colombia para controlar la tierra para la expansión del cultivo de palma de aceite.

La expansión de la frontera palmera en Colombia durante el periodo 2000-2010 demuestra que el apoyo gubernamental a las actividades extractivas constituye un factor que influye en las asimetrías de poder entre diferentes actores en términos de acceso a los recursos en las fronteras extractivas. El apoyo gubernamental lleva a resultados no equitativos cuando se traduce en mecanismos estructurales y relacionales de acceso a los recursos que facilitan la “acumulación por desposesión" y prácticas de "asimilación".

Sin embargo, el apoyo gubernamental para las actividades extractivas varía de país a país debido a que: i) cada país puede adoptar un conjunto diferente de incentivos; y ii) los mecanismos relacionales que influyen en quién se beneficia de los incentivos, y cómo, también dependen del contexto. Como consecuencia, las asimetrías de poder en el acceso a 
los recursos pueden variar de un país a otro, y también dentro de un mismo país.

El estudio empírico contenido en esta tesis muestra que el acceso no equitativo a los recursos resultante de la "acumulación por desposesión" y de prácticas de "asimilación" se expresa en las amenazas a las diversas dimensiones de los medios de vida de las poblaciones locales. Estas amenazas afectan las diferentes dimensiones de justicia: la distribución de los recursos, el reconocimiento de la cultura y la identidad, la libertad para llevar la vida que las poblaciones locales valoran vivir y la participación en las decisiones que las afectan. La respuestas de las poblaciones locales a este tipo de amenazas e injusticias dependen del contexto. Cuando hay resistencia, hay varios factores asociados al contexto y al caso específico que determinan el potencial emancipador de la misma. Los resultados empíricos presentados en esta tesis demuestran que el apoyo de terceros (por ejemplo, ONGs, organizaciones de base, la Defensoría del Pueblo, los jueces y tribunales), así como el tipo de estrategias de resistencia utilizados, son factores clave para obtener resultados emancipadores. Uno de los casos de resistencia campesina analizados en esta tesis muestra que la acción política basada en derechos humanos es un poderoso instrumento de resistencia cuando el marco normativo de los derechos humanos se aplica e interpreta de acuerdo con la constelación de significados de las poblaciones locales.

Por último, el análisis del proceso de interpretación nacional de los principios y criterios de la Mesa Redonda de Aceite de Palma Sostenible (RSPO) en Colombia demuestra que la resistencia presente en los conflictos socio-ambientales puede reproducirse bajo la forma de oposición a los instrumentos de gobernanza NSMD a nivel nacional, de tal manera que se pone en cuestión la legitimidad de estos instrumentos. Este análisis demuestra que el cuestionamiento a nivel nacional o local a la legitimidad de los instrumentos de gobernanza NSMD se produce cuando en el proceso de toma de decisiones se reproducen las asimetrías de poder locales y nacionales y se desconocen los valores de las poblaciones locales. Esto explica porqué los actores locales que se oponen a la expansión de las fronteras extractivas recurren a estrategias de resistencia por fuera de los sistemas de gobernanza NSMD. 


$$
274
$$




\section{Samenvatting}

Het hedendaagse model van wereldwijde economische ontwikkeling rust grotendeels op de globale expansie van productie grenzen, d.w.z. "de productie en distributie van bepaalde goederen, en van basisproducten in het bijzonder, die geografische ruimtes hebben geherstructureerd in een hoedanigheid die verdere expansie vereist" (Moore, 2000: 410). In dit nieuwe millennium ontwikkelt de expansie van productie grenzen zich met ongekende snelheid en schaal, waardoor zij het pad heeft geëffend voor de proliferatie van sociaalecologische conflicten (Muradian et al., 2012).

Verscheidene studies suggereren sinds de mid-1990er jaren een buitengewone stijging van de winningsintensiteit van zowel fysieke als biologische hulpbronnen, vooral in het Globale Zuiden. De meer intensive winning heeft tot een groeiende strijd geleid waarin de toegang van "sociaal benadeelde groepen" (Bryant, 1992) tot de milieus die de basis vormen van hun existentie en cultuur wordt verdedigd tegen de belangen van invloedrijke actoren die een ander en vaak conflicterend gebruik en uitbuiting van deze milieus nastreven.

De momenteel versnellende uitbreiding van productie grenzen vindt plaats op mondiale schaal. Echter, de landen-specifieke geografie en hun sociale, politieke en economische processen bepalen de manieren waarop de uitbreiding van een specifieke productgrens zich in een bepaald land voltrekt. In dit proefschrift gebruik ik het concept van 'landenspecifieke trajecten van de uitbreiding van productie grenzen' om de specifieke manieren aan te duiden waarop de uitbreiding van productie grenzen zich in een bepaald land voltrekt. Landen-specifieke trajecten behelzen verschillende praktijken om toegang tot een hulpbron te krijgen, controleren of te behouden. Deze praktijken zijn vaak ontstaan door overheidsprikkels, die extractieve activiteiten moeten ondersteunen, en deze prikkels definiëren daardoor tussen actoren asymmetrische machtsverhoudingen in de toegang tot hulpbronnen. Landen-specifieke trajecten bevatten ook de verschillende reacties van lokale sociale actoren die zich op die plekken bevinden waar expansie plaatsvindt. Deze reacties nemen vaak de vorm aan van gevechten en strijd om existenties. Strijd en conflict zijn tekenen van, en reacties op, de onrechtvaardigheden die gepaard gaan met dit soort bedreigingen van existenties (Martinez-Alier, 2013). Governance mechanismes die niet overheids-, maar marktgedreven zijn ("Non-state market-driven", NSMD), zoals vrijwillige certificeringsregelingen, hebben zich ontwikkeld tot een van de globale governance mechanismes die veelal gebruikt worden om de sociaalecologische kwesties aan te pakken die in verband worden gebracht met de expansie van agro-industriële hulpbronextractie en die de kern vormen van conflict en strijd. Echter, de processen van adoptie en implementatie van certificeringsstandaards op nationaal niveau zijn vaak arena's waarin strijd plaatsvindt, waardoor de legitimiteit van het governance systeem uitgedaagd wordt. 
De strijd om legitimatie kan geworteld zijn in: i) de andere waardes van de locale actoren ten opzichte van de waarden, die door het governance-systeem worden uitgedragen, en ii) besluitvormingsprocedures die geen rekening houden met deze pluraliteit van waarden. Lokale actoren, die de expansie van productie grenzen bekritiseren, kunnen toevlucht nemen tot verschillende strategieën buiten NSMD-governance-systemen om hun weerstand tot uitdrukking te brengen, in het bijzonder als de legitimiteit van deze governancesystemen in twijfel wordt getrokken. Mensenrechten beleid wordt vaak gebruikt als een weerstandsstrategie parallel met andere strategieën. Dit vertrouwen op mensenrechtenbeleid als een strategie van weerstand kan verklaard worden door het feit dat het mensenrechtenkader de diverse dimensies van rechtvaardigheid behelst die ten grondslag liggen aan de claims van zich verzettende actoren. Deze claims omvatten de eerlijke verdeling van de toegang tot hulpbronnen, de erkenning van het verschil in identiteit en cultuur, gelijke participatie en de vrijheid om de levens te leiden die de mensen waarderen (Schlosberg, 2007). Factoren die de legitimiteitsstrijd van NSMD duurzaamheidsgovernance-systemen op nationaal niveau beïnvloeden, maar ook de weerstandsstrategieën van lokale actoren en hun potentieel voor emancipatoire politiek zijn dus belangrijke elementen in de analyse van landen-specifieke trajecten van de expansie van productie grenzen.

Het hoofddoel van dit proefschrift is het geven van nieuwe inzichten in de manier waarop zich de groei van productie grenzen manifesteert in landen-specifieke trajecten van toegang tot, controle over en strijd om hulpbronnen. De op dit hoofddoel baserende, overkoepelende onderzoeksvraag, die voor deze dissertatie leidend is, luidt: Hoe manifesteert zich de groei van productie grenzen in landen-specifieke trajecten van onrechtvaardige toegang tot hulpbronnen?

Deze onderzoeksvraag wordt vanuit een politieke ecologie perspectief benaderd, door de expansie van de palmolie-productgrens in Colombia tussen 2000 en 2010 in combinatie met de hulpbron-toegang strijd en weerstand die daarmee verbonden is te analyseren. De wereldwijde expansie van de palmolie-productgrens vindt in verschillende landen op verschillende snelheden en schalen plaats, die de zeer verschillende contexten weergeven waarin landen-specifieke trajecten van productgrensexpansie bestudeerd moeten worden. Palmolieproductie vindt vooral plaats in het mondiale Zuiden in de tropische gebieden van Afrika, Azië en Latijn-Amerika, waar de passende landbouw-klimatologische voorwaarden aangetroffen kunnen worden die benodigd worden om de oliepalmboom te kunnen kweken. Indonesië, Maleisië, Thailand, Nigeria en Colombia zijn 's werelds vijf grootste producenten. Sinds 2000 heeft de globale palmoliemarkt een opmerkelijke 'boom' ervaren. De wereldwijde productie steeg van 21,8 miljoen ton in 2000 naar 45,8 miljoen ton in 2010. De productiegroei van palmolie heeft geleid tot een versnelde uitbreiding van 
oliepalmcultivatie in producerende landen, wat vragen opwerpt over de resulterende sociaalecologische gevolgen op lokaal niveau. Colombia is een relevante casus om te analyseren hoe de globale expansie van productie grenzen zich manifesteert in landenspecifieke trajecten van controle over en de strijd om de toegang tot hulpbronnen. Het is een van 's werelds grootste producenten van palmolie en de expansie van de productgrens versnelde over een groot gebied tussen 2000 en 2010. De hoeveelheid land waarop oliepalmen worden verbouwd is bijna verdrievoudigd van 157.000 ha in 2000 naar 404.000ha in 2010. Bovendien heeft het land herhaaldelijk negatief in de belangstelling van de literatuur gestaan die zich bezighoudt met de sociaalecologische effecten van palmolieexpansie. Onderzoekers, journalisten, en niet-overheids- en grassroots-organisaties hebben bericht over meerdere gevallen van strijd om hulpbron-toegang en sociaalecologische conflicten.

Het onderzoek is benaderd vanuit het perspectief van de politieke ecologie en maakt gebruik van de 'uitgebreide casus' methode. Ik heb ook concepten en inzichten uit andere velden gebruikt om het analytische potentieel van politieke ecologie te verrijken. In het bijzonder zijn dit concepten uit ecologische economie, politieke economie, plattelandsstudies, kritische sociologie, maar ook theorieën van milieurechtvaardigheid en mensenrechten.

Er is reeds door de wetenschap van de politieke ecologie aangetoond dat praktijken van hulpbron-controle, die gekoppeld zijn aan de expansie van productie grenzen, regelmatig uitdrukking vinden als 'accumulatie door ontneming', d.w.z. kapitaal-accumulatie door bepaalde groepen van mensen op kosten van de existenties van anderen (Harvey, 2003). Dit proefschrift toont tevens aan: i) dat praktijken van hulpbron-controle de vorm kunnen hebben van 'assimilatie' - praktijken van inlijving van lokale bevolkingen in moderne processen - als poging om een mate van gelijkheid te realiseren, terwijl verschillen in identiteit en cultuur worden geloochend (Escobar 2006a and 2006b); en ii) dat zowel 'accumulatie door onteigening' en 'assimilatie' kunnen verschijnen in veelvoudige en diverse praktijken op nationaal en lokaal niveau die ongelijke toegang tot hulpbronnen produceren. De analyse van een aantal weerstands-casussen in verband met de expansie van de palmolie-productgrens in Colombia onthult zes types van landen-specifieke praktijken van 'accumulatie door onteigening' die gebruikt worden om de controle te krijgen over het land voor de expansie van de palmoliegrens, terwijl 'assimilatie' voorkomt in een aantal contractteelt arrangementen genaamd 'productieve allianties'. Door deze praktijken konden actoren die achter de expansie van de palmoliegrens staan controle verwerven over de toegang tot land, terwijl lokale bevolkingen de controle verloren, of dreigden te verliezen, over de hulpbronnen die hun existentie uitmaakten of 'assimilatie'-praktijken accepteerden die in strijd waren met hun identiteit en 'leefwerelden' om de toegang tot hulpbronnen te 
behouden.

De expansie van een productgrens op nationaal niveau en de vormen van praktijken van hulpbron-controle op lokaal niveau worden bepaald door landen-specifieke sociaaleconomische en politieke processen en de landelijke geografie, maar ook door de materiele eisen en karakteristieken van het product. Deze factoren definiëren de fysieke ruimtes waarin de expansie plaatsvindt en hoe de controle over de toegang tot hulpbronnen kan worden verworven, verloren of behouden door de verschillende actoren in deze ruimtes. In Colombia werd de expansie van de oliepalmkweek tussen 2000 en 2010 sterk beïnvloed door een stijgende nationale oliepalmproductie voor verwerking tot biodiesel voor de nationale markt. Deze groeiende productie werd gestuurd door overheidsbeleid dat de productie en consumptie van nationale biobrandstoffen bevorderde, en dat de palmolieproductie als grondstof hiervoor ondersteunde. Overheidssteun voor de palmolie agro-industrie, marginalisering van boeren en sociaalpolitieke processen in relatie met het gewapende conflict bepaalden de landen-specifieke praktijken van 'accumulatie door onteigening' en 'assimilatie' waarvan gebruik gemaakt werd om het land voor de expansie van oliepalmkweek te controleren.

De 2000-2010 expansie van de palmoliegrens in Colombia laat zien dat overheidssteun voor extractieve activiteiten een zeer relevante factor is met invloed op hoe asymmetrische machtsverhoudingen op hun beurt de toegang tot hulpbronnen beïnvloeden. Dit soort steun resulteert in ongelijke uitkomsten als de steun in structurele en relationele toegangsmechanismes vertaald wordt die praktijken van 'accumulatie van onteigening' en 'assimilatie' faciliteren. Overheidssteun voor extractieve activiteiten varieert van land tot land omdat: i) elk land een andere reeks stimulansen kan aannemen; en ii) het netwerk van relaties die sturen wie profijt heeft van stimulansen, en hoe, ook contextafhankelijk is. Als consequentie kunnen de machtsasymmetrieën over de toegang tot hulpbronnen variëren van land tot land, en zelfs binnen landen.

De empirische studie in dit proefschrift geeft weer dat de ongelijke toegang tot hulpbronnen door 'accumulatie door onteigening' en 'assimilatie' praktijken uitdrukking vindt in bedreigingen voor diverse dimensies van de existentie van lokale bevolkingen. Deze bedreigingen representeren klachten die de dimensies van verdeling, erkenning, vermogen en participatie van rechtvaardigheid beïnvloeden. De reacties op dit soort bedreigingen en klachten door lokale bevolkingen zijn contextafhankelijk. Als er weerstand is, bepalen verschillende context- en casus-specifieke factoren het emancipatoire potentieel van weerstand. De empirische bevindingen laten zien dat steun van derden (bijvoorbeeld NGOs, grassroots organisaties, Ombudsmannen, rechtbanken) en de gebruikte types weerstandsmechanismes sleutelfactoren zijn voor de bepaling van de emancipatoire 
uitkomsten. Een van de in dit proefschrift geanalyseerde gevallen van boerenweerstand demonstreert dat mensenrechtenbeleid een machtig instrument van weerstand is als het normatieve mensenrechtenkader wordt toegepast en geïnterpreteerd overeenkomstig de betekenissen die de lokale bevolkingen er aan toekennen.

Tot besluit, toont de analyse van het nationale proces van interpretatie van de "Roundtable on Sustainable Palm Oil (RSPO)" in Colombia dat weerstand in sociaaleconomische conflicten gereproduceerd kan worden in de legitimatiestrijd van NSMD governanceinstrumenten op nationaal niveau. De studie van de RSPO in Colombia bewijst ook dat legitimatiestrijd plaatsvindt als het besluitvormingsproces lokale en nationale machtsasymmetrieën reproduceert en de waarden van de lokale bevolkingen over het hoofd ziet. Dit verklaart waarom lokale actoren die de expansie van productie grenzen bekritiseren zich tot strategieën buiten NSMD governance-systemen om wenden, om hun weerstand tot uitdrukking te brengen. 


\section{About the Author}

Victoria Marín-Burgos was born on July $10^{\text {th }}, 1976$ in Medellín, Colombia, where she did her bachelor in law. She holds a Master degree in International and European Law from Utrecht University (LL.M) and a Master degree in International Relations from Bologna University. She practiced law for eight years in her home country. On the basis of a personal commitment to investigate the situation of people affected by extractive activities and contribute to social and environmental justice, she decided to make a career shift from law practice in private organisations to research on socio-environmental conflicts. In June 2009, she started to work on her doctoral research as part of the $\mathrm{PhD}$ programme in Innovation and Governance for Sustainable Development at the Twente Centre for Studies in Technology and Sustainable Development (CSTM) - Institute for Innovation and Governance Studies (IGS) - University of Twente, in The Netherlands. The research was performed under the supervision of Prof. Dr. Jon C. Lovett and Dr. J.S. Clancy.

\section{List of publications:}

Marin-Burgos, V., Forthcoming 2014. Social-environmental conflicts and agrofuel crops: The case of oil palm expansion in Colombia, in Dietz, K., Engels, B., Pye, O., Brunnengräber A. (Eds.), The Political Ecology of Agrofuels. Routledge ISS Studies in Rural Livelihoods. Routledge, London.

Marin-Burgos, V., Clancy, J.S., Lovett, J.C., 2014 (in press). Contesting legitimacy of Voluntary Sustainability Certification Schemes: valuation languages and power asymmetries in the Roundtable on Sustainable Palm Oil in Colombia. Ecological Economics (2014), http://dx.doi.org/10.1016/j.ecolecon.2014.04.011

Marin-Burgos, V., 2013. Acceso a Recursos y Políticas Sectoriales: el caso del acceso a la tierra y los agrocombustibles en Colombia, in Pérez-Rincón, M., Rojas, J., Galvis, R. (Eds.), Sociedad y Ecosistemas: Minería, Megaproyectos y Educación Ambiental. Programa Editorial Universidad del Valle, Cali, Colombia.

Martinez-Alier J., Anguelovski I., Bond P., Del Bene D., Demaria F., Gerber J.-F., Greyl L., Haas W., Healy H., Marín-Burgos V., Ojo G., Porto M., Rijnhout L., RodríguezLabajos B., Spangenberg J., Temper L., Warlenius R., Yánez, I., 2014. Between activism and science: grassroots concepts for sustainability coined by Environmental Justice Organizations. Journal of Political Ecology 21, 19-60. 